Prepared in cooperation with the U.S. Army Corps of Engineers

\title{
Analyses of Potential Factors Affecting Survival of Juvenile Salmonids Volitionally Passing Through Turbines at McNary and John Day Dams, Columbia River
}

Open-File Report 2011-1227 



\section{Analyses of Potential Factors Affecting Survival of Juvenile Salmonids Volitionally Passing Through Turbines at McNary and John Day Dams, Columbia River}

By John Beeman, Hal Hansel, and Russell Perry, U.S. Geological Survey; and Eric Hockersmith and Ben Sandford, National Oceanic and Atmospheric Administration Fisheries

Prepared in cooperation with the U.S. Army Corps of Engineers

Open-File Report 2011-1227

U.S. Department of the Interior

U.S. Geological Survey 


\section{U.S. Department of the Interior \\ KEN SALAZAR, Secretary}

\section{U.S. Geological Survey \\ Marcia K. McNutt, Director}

U.S. Geological Survey, Reston, Virginia: 2011

For more information on the USGS-the Federal source for science about the Earth, its natural and living resources, natural hazards, and the environment, visit http://www.usgs.gov or call 1-888-ASK-USGS.

For an overview of USGS information products, including maps, imagery, and publications, visit http://www.usgs.gov/pubprod

To order this and other USGS information products, visit $h t t p: / / s t o r e . u s g s . g o v$

Suggested citation:

Beeman, J.W., Hansel, H., Perry, R.W., Hockersmith, E., and Sanford, B., 2011, Analyses of potential factors affecting survival of juvenile salmonids volitionally passing through turbines at McNary and John Day Dams, Columbia River: U.S. Geological Survey Open-File Report 2011-1227, 124 p.

Any use of trade, product, or firm names is for descriptive purposes only and does not imply endorsement by the U.S. Government.

Although this report is in the public domain, permission must be secured from the individual copyright owners to reproduce any copyrighted material contained within this report. 


\section{Contents}

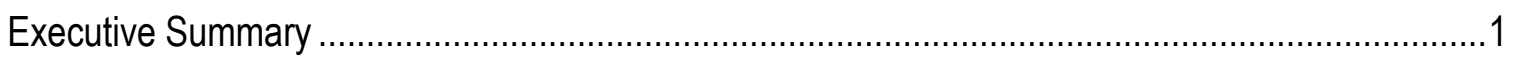

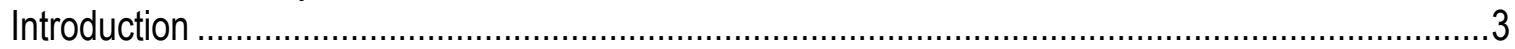

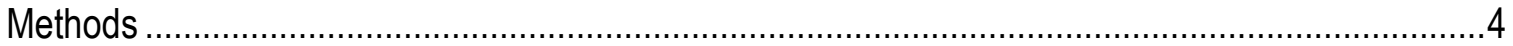

Results of Analyses from Studies at John Day Dam ............................................................13

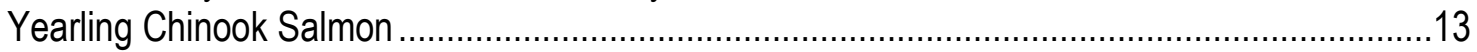

Environmental Conditions .........................................................................................

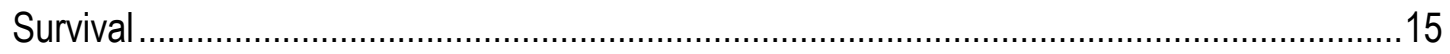

Key Findings in Data from Yearling Chinook Salmon at John Day Dam ...............................21

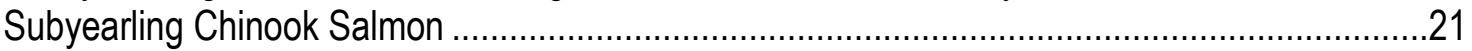

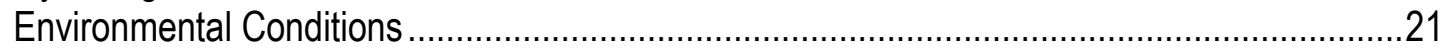

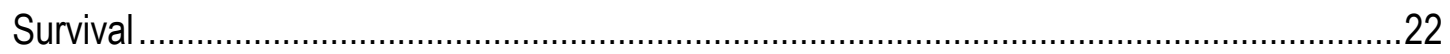

Key Findings in Data from Subyearling Chinook Salmon at John Day Dam...........................26

Results of Analyses from Studies at McNary Dam ..............................................................30

Yearling Chinook Salmon ......................................................................................

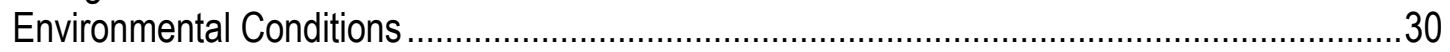

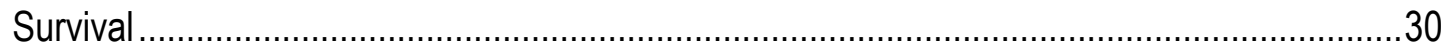

Key Findings in Data from Yearling Chinook Salmon at McNary Dam..................................37

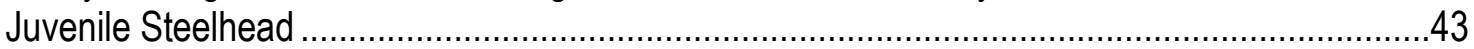

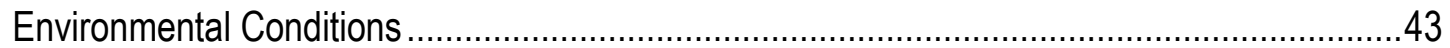

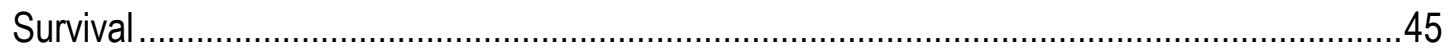

Key Findings in Data from Juvenile Steelhead at McNary Dam.........................................49

Subyearling Chinook Salmon ....................................................................................

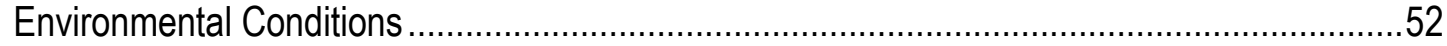

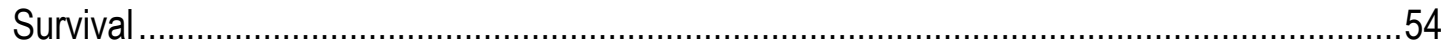

Key Findings in Data from Subyearling Chinook Salmon at McNary Dam.............................58

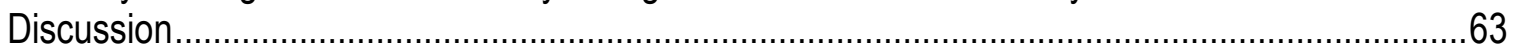

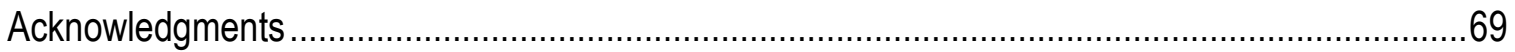

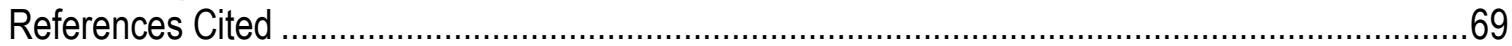

Appendix A. Summaries of Covariate Values from Data used in Studies of Yearling Chinook

Salmon at John Day Dam in 2002 and 2003 ....................................................................74

Appendix B. Capture History Summary of Yearling Chinook Salmon from data used in studies at John Day Dam in 2002 and 2003...............................................................................76

Appendix C. Model Summary from Analyses of Recapture Probabilities ( $p$ ) of Yearling Chinook Salmon from data used in studies at John Day Dam in 2002 and 2003.....................................77 Appendix D. Summaries of Covariate Values of Subyearling Chinook Salmon from data used in studies at John Day Dam in 2002 and 2003.....................................................................78 Appendix E. Capture History Summary of Subyearling Chinook Salmon from data used in studies

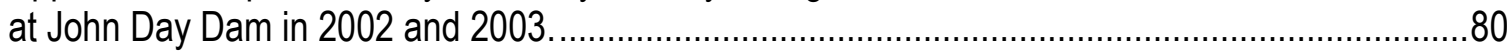
Appendix F. Model Summary from Analyses of Recapture Probabilities ( $p$ ) of Subyearling Chinook Salmon from data used in studies at John Day Dam in 2002 and 2003 ...................................... 81 Appendix G. Summaries of Covariate Values from Yearling Chinook Salmon from data used in studies at McNary Dam from 2002-2009.

Appendix H. Capture History Summary of Yearling Chinook Salmon from Data Used in Studies at McNary Dam in 2002-2005, and 2009. 
Appendix I. Correlation Analyses of Yearling Chinook Salmon from Data Used in Studies at McNary Dam in 2002-2005, and 2009.

Appendix J. Model Summary from Analyses of Recapture Probabilities ( $p$ ) of Yearling Chinook Salmon from Data Used in Studies at McNary Dam in 2002-2005, and 2009.

Appendix K. Model-selection Results from Radio- and Acoustic-tagged Yearling Chinook Salmon from Data Used in Studies at McNary Dam in 2002-2005, and 2009.

Appendix L. Beta (Slope) Coefficients of Estimable Survival Parameters of Yearling Chinook Salmon from Data Used in Studies at McNary Dam in 2002-2005, and 2009...........................93 Appendix M. Capture History Summary of Yearling Chinook Salmon from Data Used in Studies at McNary Dam in 2002-2005, and 2009.....

Appendix M. Capture History Summary of Yearling Chinook Salmon from Data Used in Studies at McNary Dam in 2002-2005, and 2009...

Appendix N. Model Summary from Analyses of Recapture Probabilities (p) of Yearling Chinook Salmon from Data Used in Studies at McNary Dam in 2002-2005, and 2009.

Appendix O. Summaries of Covariate Values of Juvenile Steelhead from Data Used in Studies at McNary Dam in 2004-2009.

Appendix P. Capture History Summary of Juvenile Steelhead from Data Used in Studies at McNary Dam in 2004-2005 and 2009.

Appendix Q. Results of Correlation Analyses of Juvenile Steelhead from Data Used in Studies at McNary Dam in 2004-2005 and 2009.

Appendix R. Model Summary from Analyses of Recapture Probabilities ( $p$ ) of Juvenile Steelhead from Data Used in Studies at McNary Dam in 2004-2005 and 2009.

Appendix S. Model-selection Results from Radio- and Acoustic-tagged Juvenile Steelhead from

Data Used in Studies at McNary Dam in 2004-2005 and 2009.

Appendix T. Beta (Slope) Coefficients of Estimable Survival Parameters of Juvenile Steelhead

from Data Used in Studies at McNary Dam in 2004-2005 and 2009.

Appendix U. Capture History Summary of Juvenile Steelhead from Data Used in Studies at McNary Dam in 2004-2005 and 2009.

Appendix V. Model Summary from Analyses of Recapture Probabilities (p) of Juvenile Steelhead

from Data Used in Studies at McNary Dam in 2004-2005 and 2009.

Appendix W. Summaries of Covariate Values of Subyearling Chinook Salmon from Data Used in

Studies at McNary Dam in 2004-2009.

Appendix X. Capture History Summary of Subyearling Chinook Salmon from Data Used in Studies

at McNary Dam in 2004-2009.

Appendix Y. Results of Correlation Analyses Subyearling Chinook Salmon from Data Used in

Studies at McNary Dam in 2004-2005 and 2009...

Appendix Z. Model Summary from Analyses of Recapture Probabilities (p) of Subyearling Chinook

Salmon from Data used in Studies at McNary Dam in 2004-2005 and 2009.

Appendix AA. Model-selection Results from Radio- and Acoustic-tagged Subyearling Chinook

Salmon from Data used in Studies at McNary Dam in 2004-2005 and 2009...........................120

Appendix AB. Beta (Slope) Coefficients of Estimable Survival Parameters of Subyearling Chinook

Salmon from Data used in Studies at McNary Dam in 2004-2005 and 2009.....

Appendix AC. Capture History Summary of Subyearling Chinook Salmon from Data Used in

Studies at McNary Dam in 2004-2009.

Appendix AD. Model Summary from Analyses of Recapture Probabilities ( $p$ ) of Subyearling Chinook Salmon from Data used in Studies at McNary Dam in 2004-2009 


\section{Figures}

Figure 1. Graph showing turbine unit discharges during yearling Chinook salmon passage (bars) and turbine efficiency (solid line) from data used in studies at John Day Dam in 2002 and 2003.

Figure 2. Graph showing daily-averaged covariate values for yearling Chinook salmon from data used in studies at John Day Dam in 2002 and 2003.

Figure 3. Graph showing number of yearling Chinook salmon passing through each

turbine by year (bars) and the percentage of time each turbine was operated (line) from

data used in studies at John Day Dam in 2002 and 2003

Figure 4. Graph showing estimated effects of water temperature (upper plate) and tag burden

(lower plate) on apparent survival of yearling Chinook salmon from data used in studies at John

Day Dam in 2002 and 2003.

Figure 5. Graph showing turbine unit discharges during subyearling Chinook salmon passage (bars) and turbine efficiency (solid line) from data used in studies at John Day Dam in 2002 and 2003.

Figure 6. Graph showing daily-averaged covariate values for subyearling Chinook

salmon used in analyses of survival from data used in studies at John Day Dam in 2002

and 2003

Figure 7. Graph showing number of subyearling Chinook salmon passing through

each turbine by year (bars) and the percentage of time each turbine was operated (line)

from data used in studies at John Day Dam in 2002 and 2003.

Figure 8. Graph showing estimated effects of water temperature in 2002 (upper plate) and 2003

(middle plate) and turbine discharge (lower plate) on apparent survival of subyearling Chinook salmon from data used in studies at John Day Dam in 2002 and 2003

Figure 9. Graph showing turbine unit discharges during yearling Chinook salmon

passage (bars) and turbine efficiency (solid line) from data used in studies at McNary

Dam in 2002-2005 and 2009.

Figure 10. Graph showing daily-averaged covariate values for yearling Chinook salmon

from data used in studies at McNary Dam in 2002-2009.

Figure 11. Graph showing number of yearling Chinook salmon passing through each turbine by year (bars) and overall percentage of time each turbine was operating (line) from data used in studies at McNary Dam in 2002-2005 and 2009

Figure 12. Graph showing estimated effects of head on apparent survival of yearling

Chinook salmon at McNary Dam in 2002-2009

Figure 13. Graph showing estimated effects of water temperature on apparent survival of yearling Chinook salmon from data used in studies at McNary Dam in 2002-2009.

Figure 14. Graph showing estimated effects of tag burden on apparent survival of yearling Chinook salmon from data used in studies at McNary Dam in 2002-2009.

Figure 15. Graph showing turbine unit discharges during juvenile steelhead passage (bars) and turbine efficiency (solid line) from data used in studies at McNary Dam in 2004-2009.....

Figure 16. Graph showing daily-averaged covariate values for juvenile steelhead from data used in studies at McNary Dam in 2004-2009.

Figure 17. Graph showing number of juvenile steelhead passing through each turbine by year (bars) and overall percentage of time individual turbine units were operating (line) from data used in studies at McNary Dam in 2004, 2005, and 2009. 
Figure 18. Graph showing estimated effects of head (upper plate) and spill percentage (lower plate) on apparent survival of juvenile steelhead at McNary Dam 2004-2009

Figure 19. Graph showing turbine unit discharges during subyearling Chinook salmon passage (bars) and turbine efficiency (solid line) from data used in studies at McNary Dam in 2004-2009.

Figure 20. Graph showing daily-averaged covariate values for subyearling Chinook salmon from data used in studies at McNary Dam in 2004-2009

Figure 21. Graph showing number of subyearling Chinook salmon passing through each turbine by year (bars) and overall (line) from data used in studies at McNary Dam in 2004, 2005 , and 2009 .

Figure 22. Graph showing estimated effects of water temperature on apparent survival of subyearling Chinook salmon from data used in studies at McNary Dam in 2004-2009.

Figure 23. Graph showing estimated effects of spill percentage on apparent survival of subyearling Chinook salmon from data used in studies at McNary Dam in 2004-2009.

\section{Tables}

Table 1. Dam operations during studies used in the analysis of factors affecting survival of tagged fish passing turbines.............................................................................................. 6

Table 2. Variables used in analyses of the survival of fish passing turbines................................10

Table 3. A priori order of covariate evaluations .................................................................12

Table 4. Correlation indices of data from yearling Chinook salmon from the turbine group from data used in studies at John Day Dam in 2002 and 2003 ............................................17

Table 5. Correlation indices of data from yearling Chinook salmon from the control group from data used in studies at John Day Dam in 2002 and 2003.

Table 6. Model-selection results of data from radio-tagged yearling Chinook salmon used in studies at John Day Dam in 2002 and 2003.

Table 7. Beta (slope) coefficients of estimable survival parameters of yearling Chinook salmon

from data used in studies at John Day Dam in 2002 and 2003 ...............................................20

Table 8. Correlation indices of data from subyearling Chinook salmon from the turbine group from data used in studies at John Day Dam in 2002 and 2003 ..............................................2

Table 9. Correlation indices of data from subyearling Chinook salmon from the control group from data used in studies at John Day Dam in 2002 and 2003 ...............................................26

Table 10. Model-selection results of data from radio-tagged subyearling Chinook salmon used in studies at John Day Dam in 2002 and 2003.

Table 11. Beta (slope) coefficients of estimable survival parameters of subyearling Chinook salmon from data used in studies at John Day Dam in 2002 and 2003

Table 12. Table of correlation indices of data from yearling Chinook salmon from the turbine group from data used in studies at McNary Dam in 2002-2009.

Table 13. Table of correlation indices of data from yearling Chinook salmon from the control group from data used in studies at McNary Dam in 2002-2009

Table 14. Model-selection results from radio- and acoustic-tagged yearling Chinook salmon from data used in studies at McNary Dam in 2002-2009

Table 15. Beta (slope) coefficients of estimable survival parameters of yearling Chinook salmon from data used in studies at McNary Dam in 2002-2009

Table 16. Table of correlation indices of data from juvenile steelhead from the turbine group from data used in studies at McNary Dam in 2004-2009. 
Table 17. Table of correlation indices of data from juvenile steelhead from the control group from data used in studies at McNary Dam in 2004-2009.

Table 18. Model-selection results from radio- and acoustic-tagged juvenile steelhead from data used in studies at McNary Dam in 2004-2009.

Table 19. Beta (slope) coefficients of estimable survival parameters of juvenile steelhead from data used in studies at McNary Dam in 2004-2009.

Table 20. Table of correlation indices of data from subyearling Chinook salmon from the turbine group from data used in studies at McNary Dam in 2004-2009

Table 21. Table of correlation indices of data from subyearling Chinook salmon from the control group from data used in studies at McNary Dam in 2004-2009...

Table 22. Model-selection results from radio- and acoustic-tagged subyearling Chinook salmon from data used in studies at McNary Dam in 2004-2009

Table 23. Beta (slope) coefficients of estimable survival parameters of subyearling

Chinook salmon from data used in studies at McNary Dam in 2004-2009 60 


\title{
Conversion Factors, Datums, and Abbreviations and Acronyms
}

\section{Conversion Factors}

Inch/Pound to SI

\begin{tabular}{lll}
\hline \multicolumn{1}{c}{ Multiply } & \multicolumn{1}{c}{ By } & \multicolumn{1}{c}{ To obtain } \\
\hline foot $(\mathrm{ft})$ & 0.3048 & meter $(\mathrm{m})$ \\
cubic foot per second $\left(\mathrm{ft}^{3} / \mathrm{s}\right)$ & 0.02832 & cubic meter per second $\left(\mathrm{m}^{3} / \mathrm{s}\right)$ \\
\hline
\end{tabular}

SI to Inch/Pound

\begin{tabular}{lccc}
\hline Multiply & By & To obtain \\
\hline kilometer $(\mathrm{km})$ & 0.6214 & mile $(\mathrm{mi})$ &
\end{tabular}

Temperature in degrees Celsius $\left({ }^{\circ} \mathrm{C}\right)$ may be converted to degrees Fahrenheit $\left({ }^{\circ} \mathrm{F}\right)$ as follows:

$$
{ }^{\circ} \mathrm{F}=\left(1.8 x^{\circ} \mathrm{C}\right)+32 \text {. }
$$

\section{Datums}

Horizontal coordinate information is referenced to the World Geodetic System of 1984 (WGS84).

Vertical coordinate information is referenced to the National Geodetic Vertical Datum of 1929 (NGVD 29).

\author{
Abbreviations and Acronyms \\ AICc Akaike Information Criterion adjusted to reflect the effects of sample size \\ BIOP Biological opinion \\ FCRPS Federal Columbia River Power System \\ NOAA National Oceanic and Atmospheric Administration \\ rkm river kilometer \\ USACE U.S. Army Corps of Engineers \\ USGS U.S. Geological Survey
}




\section{Analyses of Potential Factors Affecting Survival of Juvenile Salmonids Volitionally Passing Through Turbines at McNary and John Day Dams, Columbia River}

By John Beeman, Hal Hansel, and Russell Perry, U.S. Geological Survey; and Eric Hockersmith and Ben Sandford, National Oceanic and Atmospheric Administration Fisheries

\section{Executive Summary}

This report describes analyses of data from radio- or acoustic-tagged juvenile salmonids passing through hydro-dam turbines to determine factors affecting fish survival. The data were collected during a series of studies designed to estimate passage and survival probabilities at McNary (2002-09) and John Day (2002-03) Dams on the Columbia River during controlled experiments of structures or operations at spillways. Relatively few tagged fish passed turbines in any single study, but sample sizes generally were adequate for our analyses when data were combined from studies using common methods over a series of years. We used information-theoretic methods to evaluate biological, operational, and group covariates by creating models fitting linear (all covariates) or curvilinear (operational covariates only) functions to the data. Biological covariates included tag burden, weight, and water temperature; operational covariates included spill percentage, total discharge, hydraulic head, and turbine unit discharge; and group covariates included year, treatment, and photoperiod. Several interactions between the variables also were considered. Support of covariates by the data was assessed by comparing the Akaike Information Criterion of competing models. The analyses were conducted because there was a lack of information about factors affecting survival of fish passing turbines volitionally and the data were available from past studies. The depth of acclimation, tag size relative to fish size (tag burden), turbine unit discharge, and area of entry into the turbine intake have been shown to affect turbine passage survival of juvenile salmonids in other studies. 
This study indicates that turbine passage survival of the study fish was primarily affected by biological covariates rather than operational covariates. A negative effect of tag burden was strongly supported in data from yearling Chinook salmon at John Day and McNary dams, but not for subyearling Chinook salmon or juvenile steelhead. The negative effect of tag burden in data we examined from yearling Chinook salmon supports the recent findings from laboratory studies of barotrauma effects. A curvilinear (quadratic) effect of turbine unit discharge was weakly supported in data from subyearling Chinook salmon at John Day Dam. The maximum survival from those data was estimated to occur at a discharge of 15.9 thousand cubic feet per second, but the estimate was imprecise (95 percent confidence interval of -1.7-33.7 thousand cubic feet per second). This estimate is within the range of 1 percent of peak turbine operating efficiency (12.0-21.6 thousand cubic feet per second), but is lower than the 17.2 thousand cubic feet per second discharge at peak operating efficiency (at a head of 102 feet near the median in the data we examined). Effects of water temperature were supported in four of the five examined data sets and were strongly supported in all but one. Spill percentage, head, and total discharge received weak or moderate support in some cases.

The results are consistent with those of several controlled field experiments of turbine discharge. Studies based on the Hi-Z Turb'N tag (balloon tag) often show small, generally statistically insignificant, differences in survival at different turbine discharge levels. Some studies also show that a quadratic equation can be well fit to the relation of survival and turbine unit discharge. The lack of support for the operational covariates in most of the data sets we examined may be due to the small effect turbine discharge has even in controlled studies, the observational nature of the data we used, and the evaluation method. We assessed support of the data for models of linear and quadratic effects, whereas controlled experiments often statistically compare the point estimates of survival from each operational treatment studied. The results of our analyses suggest tag burden should be minimized or controlled for in analyses of future studies of passage survival and that water temperature also should be considered as a factor. This study may be the first to use data from juvenile salmonids entering turbines volitionally to assess factors affecting their turbine passage survival. Analyses of other data sets from fish with similar attributes should be conducted to corroborate these results. 


\section{Introduction}

Hydroelectric dams are often cited as one cause of reductions in populations of anadromous salmonids (National Research Council, 1996). Adult anadromous fish in rivers with hydroelectric dams often must cross dams as they migrate upstream to spawn and their offspring must cross them as they migrate to the ocean to rear. The use of fish ladders generally has been a successful means of providing upstream passage for adult salmonids, resulting in little passage delay and high passage survival (Keefer and others, 2004). Cumulative survival of juveniles during their downstream migration, however, is lower, and has been a focus area for improvements (Muir and others, 2001; Williams and others, 2001). As a result, a recent biological opinion (BIOP) for the Federal Columbia River Power System (FCRPS) set minimum standards for dam passage survival of juvenile salmonids (National Oceanic and Atmospheric Administration's National Marine Fisheries Service, 2008).

Actions to improve dam passage survival of juvenile salmonids in the FCRPS have traditionally focused on reducing passage through routes with low survival and increasing passage through routes with high survival. Generally, juvenile salmonid survival is highest through spillways, intermediate through turbine bypass systems, and lowest through turbines (Muir and others, 2001). As such, efforts to improve survival of juvenile salmonids since about 1995 have primarily focused on improving the probability of passage and survival through the spillways at FCRPS dams (Swan and others, 1997; Hansel and others, 2004; Johnson and others, 2005; Beeman and others, 2010).

Little effort has been directed toward improving survival of juvenile salmonids passing turbines relative to the other routes. This is unfortunate, because it may be more cost-effective to make improvements in turbine design or operation than to structures or operations of bypass systems or spillways. Turbines at several FCRPS dams are nearing their replacement age, and new fish-friendly designs may be beneficial to both fish and power generation (Odeh, 1999; Cada, 2001; Cada and others, 2006). Causes of mortality during turbine passage include exposure to shear, strike, and rapid pressure changes. Odeh (1999) and Cada (2001) provide descriptions of potential sources of mortality during turbine passage.

One management action intended to maximize turbine passage survival is the BIOP mandate to operate Kaplan turbines within 1 percent of their peak efficiency. This is based on data from Bell (unpub. data), suggesting this would provide the greatest survival. Several studies conducted to test this premise have shown that the peak survival does not always coincide with the " 1 percent rule", and is often associated with higher discharges (Mathur and others, 2000; Skalski and others, 2002a; Normadeau Associates and others, 2003, 2008). These results, and supporting results from physical models of turbines, have prompted further research into the relation between turbine operating conditions and fish survival. The goal of this research is to determine the turbine operating criteria, or "operating point," that optimizes survival of juvenile salmonids passing through them. Such information could be used to design new turbine operating conditions and potentially new turbine designs.

Most studies of juvenile salmonid turbine passage survival have been based on surface-acclimated fish fitted with the Hi-Z Turb'n tag (balloon tag; Heisey and others, 1992; Mathur and others, 1996, 2000; Normadeau Associates and others, 2003, 2008). 
These studies were based on juvenile salmonids, often taken directly from a hatchery, fitted with an externally attached radio transmitter and an externally attached small inflatable balloon. The fish are passed through a hose directly into the turbine intake or runner after injecting the balloon with a liquid to cause it to inflate shortly after release. The balloon facilitates recapture following passage after locating fish visually and with radio telemetry. These studies have been useful for testing the effects of various turbineoperating conditions on fish survival. However, results from these studies show that the elevation of entry into the turbine intake can affect turbine passage survival, and results from Brown and others (2009), and Carlson and others (2010) show that depth of acclimation is also an important factor. Therefore, it is beneficial to have data from depth-acclimated volitionally passing fish from which to draw inference. This report describes analyses of such data.

Data from volitionally passing juvenile salmonids are available from many studies conducted to estimate dam passage and survival probabilities. These studies are common in the FCRPS and typically are conducted to assess changes in operations or structures at passage routes other than turbines (see Skalski and others, 2002b; Axel and others, 2004a, 2004b; Counihan and others, 2006a, 2006b; Adams and Liedtke, 2010; Beeman and others, 2010). Fish with attached negatively buoyant transmitters must add air to their swim bladders to regain neutral buoyancy, a process that may take several hours (Fried and others, 1976). The fish in the studies we used were held 12-24 hours after tagging and were released into the Columbia River about 10-20 km upstream from the dams and are assumed to be neutrally buoyant at the time of release. Few fish from individual studies pass turbines, due to the structures and operations designed to minimize turbine passage, and thus individual annual studies are not likely to be suitable for analyses of factors affecting survival of turbine-passing fish. For example, in one study, 185 of 2,400 yearling Chinook salmon released in the reservoir upstream from McNary Dam (Columbia River kilometer [rkm] 470), were estimated to have passed the 14-unit powerhouse through the turbines (Adams and others, 2010). However, sample sizes increase when a suite of annual studies based on similar methods is considered together, which is the approach we describe in this report.

We had several hypotheses: (1) fish survival would be related to operational covariates, (2) fish survival would be higher during conditions of open geometry (that is, similar [aligned] wicket gate and stay vane angles and higher unit discharges), and (3) tag burden would pose a negative effect on survival. The latter hypothesis was based on results from Brown and others (2009) and Carlson and others (2010), indicating that tag burden was one of several important factors determining mortal injury of tagged fish in controlled laboratory experiments of simulated turbine passage.

\section{Methods}

Data from previous studies of dam passage survival were used to determine if several factors of interest affected survival of fish passing through turbines. The original purpose of the studies was to estimate the passage proportions and apparent survival of tagged yearling Chinook salmon (Oncorhynchus tshawytscha), subyearling Chinook salmon, and juvenile steelhead (O. mykiss) relative to structural or operational changes designed to improve passage survival of juvenile salmonids. Many of the changes in structure or operation were adaptively altered over the years of study. 
None of the studies was designed specifically to determine the factors affecting survival of fish passing turbines, but the data needed for doing so were available in most cases. For example, in many of the studies, the date, time, and turbine unit of passage were determined for most fish and the physical, biological, and operational covariates at that time were known. However, there was no experimental operation of the turbines during these studies, such as changing head or turbine discharge on a predetermined schedule. A summary of the dam operations during the years used in analyses is by dam, year, and season (spring or summer) is shown in table 1.

Analyses of data from John Day Dam (rkm 347) were based on studies in 2002 and 2003 (table 1). Data from John Day Dam were selected for analysis due to the wide range of unit discharges for these turbines within the 1 percent rule. Unit discharges within the 1 percent rule at John Day Dam at a typical head of $102 \mathrm{ft}$ range from 12.1 to 21.6 thousand $\mathrm{ft}^{3} / \mathrm{s}$ with a peak efficiency at 17.2 thousand $\mathrm{ft}^{3} / \mathrm{s}$ (Wittinger and others, 2010). For comparison, unit discharges within the 1 percent rule at McNary Dam at a typical head of $72 \mathrm{ft}$ range from 7.9 to 12.4 thousand $\mathrm{ft}^{3} / \mathrm{s}$ with a peak efficiency at 10.0 thousand $\mathrm{ft}^{3} / \mathrm{s}$ (Wittinger and others, 2010). Percentage of spill at John Day Dam during spring 2002 and 2003 was varied to evaluate juvenile fish passage and survival during 12- and 24-hour spill. In 2002, the treatments were 24-hour 30 percent spill compared to 0 percent day spill with 60 percent night spill. In 2003, there was no planned spill during the day and the treatments were 45 percent night spill compared to 60 percent night spill. In each year, the treatments were alternated for 3 days each within 6-day blocks following a randomized block design, with changes between day and night operations at 0600 and 1800 hours. The study designs are described in more detail in Hansel and others (2004), Beeman and others (2006), and Counihan and others (2006a, 2006b).

Analyses of data from McNary Dam were based on studies conducted from 2002 to 2009. Data from McNary Dam were selected for analysis due to the many years of data available resulting in attractive sample sizes of fish passing through turbines. Various planned spill operations occurred at McNary Dam during the study years. Percentage of spill during spring at McNary Dam from 2002 through 2004 was dominated by night spill to the gas cap operations (that is, until a regionally approved limit of total dissolved gas supersaturation was reached downstream; "fish passage plan spill"). During 2005 through 2007, fish-passage plan spill compared to 24-hour spill and other spill tests associated with the installation and performance of temporary spillway weirs were investigated. In 2008 and 2009, there were no specific spill treatments. During summer 2005, an involuntary spill was followed by a court-ordered spill, and in 2006-07, a 24-hour 40 percent spill compared to a 24 -hour 60 percent spill was evaluated. There were no planned spill treatments during the summers in 2004 and 2009. For more specific information on yearly study designs and spill operations at McNary Dam see Axel and others (2004a, 2004b), Perry and others (2006), Adams and others (2008), Adams and Counihan (2009), and Adams and Liedtke (2009, 2010). 
Table 1. Dam operations during studies used in the analysis of factors affecting survival of tagged fish passing turbines.

\begin{tabular}{|c|c|c|c|c|c|}
\hline Dam & Year & Season & Operating conditions & $\begin{array}{c}\text { Dates of turbine } \\
\text { passage }\end{array}$ & Reference \\
\hline \multirow[t]{4}{*}{ John Day } & \multirow[t]{2}{*}{2002} & Spring & $\begin{array}{l}\text { 24-h } 30 \text { percent spill vs. } 60 \text { percent } \\
\text { night spill }\end{array}$ & Apr. 30-May 31 & \multirow[t]{2}{*}{$\begin{array}{l}\text { Counihan and others, } \\
2006 \mathrm{a}\end{array}$} \\
\hline & & Summer & $\begin{array}{l}24-\mathrm{h} 30 \text { percent spill vs. } 60 \text { percent } \\
\text { night spill }\end{array}$ & June 25-July 16 & \\
\hline & \multirow[t]{2}{*}{2003} & Spring & $\begin{array}{l}45 \text { percent night spill vs. } 60 \text { percent } \\
\text { night spill }\end{array}$ & Apr. 30-June 6 & \multirow[t]{2}{*}{$\begin{array}{l}\text { Counihan and others } \\
2006 \mathrm{~b}\end{array}$} \\
\hline & & Summer & $\begin{array}{l}24 \text {-h } 30 \text { percent spill vs. } 60 \text { percent } \\
\text { night spill }\end{array}$ & June 23-July 25 & \\
\hline \multirow[t]{13}{*}{ McNary } & 2002 & Spring & Night spill to gas cap & May 8-June 5 & $\begin{array}{l}\text { Axel and others, } \\
\text { 2004a }\end{array}$ \\
\hline & 2003 & Spring & Night spill to gas cap & May 2-June 9 & $\begin{array}{l}\text { Axel and others, } \\
2004 \mathrm{~b}\end{array}$ \\
\hline & 2004 & $\begin{array}{l}\text { Spring } \\
\text { Summer }\end{array}$ & $\begin{array}{l}\text { Night spill to gas cap } \\
\text { No treatments }\end{array}$ & $\begin{array}{l}\text { Apr. 24-May } 25 \\
\text { July } 1-\text { July } 31\end{array}$ & $\begin{array}{l}\text { Perry and others, } \\
2006\end{array}$ \\
\hline & \multirow[t]{2}{*}{2005} & Spring & 12-h vs. 24-h & Apr. 23-June 2 & \multirow{2}{*}{$\begin{array}{l}\text { Perry and others, } \\
2007\end{array}$} \\
\hline & & Summer & $\begin{array}{l}\text { Involuntary spill then Court- } \\
\text { ordered spill }\end{array}$ & June 23-Aug. 1 & \\
\hline & \multirow[t]{2}{*}{2006} & Spring & Fish Passage Plan vs. 2006 test spill & Apr. 27-June 4 & \multirow{2}{*}{$\begin{array}{l}\text { Adams and others, } \\
2008\end{array}$} \\
\hline & & Summer & $\begin{array}{l}\text { 24-h } 40 \text { percent spill vs. } 24-\mathrm{h} 60 \\
\text { percent spill }\end{array}$ & June 20-July 27 & \\
\hline & \multirow[t]{2}{*}{2007} & Spring & $\begin{array}{l}2007 \text { test spill vs. Modified } 2006 \\
\text { test spill }\end{array}$ & Apr. 19-June 7 & \multirow[t]{2}{*}{$\begin{array}{l}\text { Adams and } \\
\text { Counihan, } 2009\end{array}$} \\
\hline & & Summer & 40 percent spill vs. 60 percent spill & June 20-July 28 & \\
\hline & \multirow[t]{2}{*}{2008} & Spring & No treatments & Apr. 20-June 4 & \multirow{2}{*}{$\begin{array}{l}\text { Adams and Liedtke, } \\
2009\end{array}$} \\
\hline & & Summer & 40 percent spill vs. 60 percent spill & June 20-Aug. 2 & \\
\hline & \multirow[t]{2}{*}{2009} & Spring & No treatments & Apr. 18-June 4 & \multirow{2}{*}{$\begin{array}{l}\text { Adams and Liedtke, } \\
2010\end{array}$} \\
\hline & & Summer & No treatments & June 20-Aug. 9 & \\
\hline
\end{tabular}

The studies were based on fish tagged with radio or acoustic transmitters and incorporated means of detection suitable for determining time spent in the river and forebay upstream from the dam, assigning route-specific passage at the dam, as well as detections downstream from which to estimate dam passage survival. For the purposes of these analyses, the date, time, and turbine unit of passage and at least two detection sites downstream were required. The locations of the sites downstream varied slightly over the years of study at McNary Dam, but were the same during both years at John Day Dam. Studies at McNary Dam used 2-7 detection sites downstream during any 1 year of study, ranging from 11 to $161 \mathrm{~km}$ downstream from the dam. Six downstream detection sites ranging from 10 to $74 \mathrm{~km}$ downstream from the dam were used in the studies at John Day Dam.

The data from the tagged fish were compiled from databases created during the original studies and added to environmental and operational data. The environmental and operational data were provided by the U.S. Army Corps of Engineers (Jon Renholds, 
written commun.) either during the original studies, or in some cases, specifically for this analysis. Dam operations data from John Day Dam in 2000 were not available on a turbine-unit-specific basis and few tagged fish passed through turbines during studies that year, so the data from 2000 were omitted from analyses.

The spatial resolution of the fish data was usually sufficient to assign a specific turbine unit of passage, but in some years at McNary Dam passage was assigned to a group of turbine units. At McNary Dam, unit-specific resolution was available only in data from yearling Chinook salmon during 2002-05 and 2009 and in data from juvenile steelhead and subyearling Chinook salmon during 2004, 2005, and 2009. Therefore, analyses of these years was conducted prior to all-year analyses to determine if the potential effects of turbine unit discharge would be affected by the resolution of the passage assignments. If turbine unit discharge was not supported as a factor affecting turbine passage survival in these analyses, the full data set was used for subsequent analyses of all covariates. The most resolute data available were used to assign operations data to the time of passage for analyses of the all-year McNary data, but a south (units 17) or north (units 8-14) assignment was used for turbine unit location, as this was the only resolution common to all years. The average of the unit discharges of the operating units to which fish passage was assigned was used as the passage unit discharge when unit-specific passage data were not available. Unit-specific passage data at John Day Dam were available for all years and were used to obtain operating conditions at the time of passage, but the variable of turbine unit location was grouped into south (units 1-8) or north (units 9-16) areas to reduce the number of parameters in the analysis, because relatively few fish were in the data set. The chronological resolution of the operations data was hourly at McNary Dam in 2002 and 2003 and at John Day Dam in 2002 and until noon on May 1, 2003. All other operations data were available at 5-minute intervals. The data from the nearest period available were used as the condition at the time of turbine passage.

Apparent survival was estimated using Cormack-Jolly-Seber capture-recapture methods (Cormack, 1964; Jolly, 1965; Seber, 1965). Apparent survival is the probability that an animal survives and remains available for recapture. In the context of this study, fish that lose their tags leave the study area and do not return, or cease migrating between detection sites are assumed to be mortalities. All references to survival in this report refer to apparent survival.

The probability of detection at a site is the product of the probability of survival to the site and the probability of recapture at the site, so these parameters must be separately estimated. Thus, models contain parameters to estimate recapture probability and to estimate survival, although only those used to estimate survival are typically of interest.

Capture histories were created from the data for use in models of recapture and survival probabilities. A capture history is a series of values representing if tagged animals were alive when released and if they were detected passing each detection site or recapture occasion. In most studies used in these analyses, treatment fish were released upstream from the dam and control fish were released downstream from the dam, because relative survival was estimated in the original studies using methods such as the routespecific survival model (Skalski and others, 2002b). The only exception was the studies at McNary Dam in 2002 and 2003, which did not include a control group. We used data from the control group to represent riverine conditions present during the studies apart 
from powerhouse operations by assessing the effects of total river discharge on the survival of this group. All estimates of survival were based on single-release models and represented the survival from turbine passage to the first downstream detection site. In analyses of data from McNary Dam, the distance between these points was used as a model covariate to account for differences in site placements among years and the same values were used for control and turbine fish. The site locations were identical in each year of study at John Day Dam.

The goal of this study was to determine effects of the factors of interest on inriver survival between turbine passage and the nearest downstream detection site, so data from subsequent downstream detection sites were combined. For example, at John Day Dam in 2002, there were detection sites at rkms 337, 324, 309, 287, and 273, but data from sites downstream from rkm 337 were pooled into a single occasion. This resulted in a three-occasion data structure for analysis, including release, the first site downstream from the dam, and all sites downstream from the first.

The variables used in the analyses included group and individual covariates and were selected based on results of a meeting of biologists and engineers from U.S. Geological Survey (USGS), National Oceanic and Atmospheric Administration (NOAA), and the U.S. Army Corps of Engineers (USACE) held at the USACE Portland District office on April 13, 2010. The meeting resulted in a list of biological, physical, and operational covariates to use as covariates in a priori models of the survival of tagged fish passing turbines.

The variables can be classified into group and individual covariates describing operational or biological factors (table 2). Group covariates included treatment, year, photoperiod (day or night based on civil twilight at the time of turbine passage or release of the control group), and river reach. Operational variables included head (forebay elevation minus tailwater elevation, in feet), spill percentage, turbine discharge, total dam discharge, and turbine location (the unit number, or bivariate division by north or south). Discharge variables were in units of thousand cubic feet per second (thousand $\mathrm{ft}^{3} / \mathrm{s}$ ). Biological variables included tag burden percentage (tag weight in air * 100/fish weight in air) and water temperature at the regional tailrace water-quality measurement site. Several interactions between variables also were included. The turbine location and photoperiod interaction was used to account for potential differences in predation in the tailrace, assuming that the location of turbine of passage may affect predation downstream and be influenced by the ambient light. Total discharge was applied to data from fish in the control group as a potential measure of overall effects of discharge, but was not applied to data from fish in the turbine group because it was highly correlated with hydraulic head and the latter variable was thought to be more pertinent for fish passing turbines. Bivariate and multivariate collinearity was assessed using Pearson's r and variance inflation factor prior to survival analyses to avoid using highly correlated variables in models together. Using correlated or collinear variables together in models makes it difficult to separate their separate influence on the response variable, which in our analyses was survival of fish passing through turbines. This is indicated when Pearson's $\mathrm{r}$ is greater than an absolute value of about $0.8(|0.8|)$, and generally as variance inflation factors increase (Belsley and others, 1980). 
The effects of the covariates on fish survival were evaluated using an informationtheoretic approach. In this approach, mathematical models representing hypotheses are compared based on the principle of parsimony. Parsimony is the balance between bias and variance of prediction. The square of bias is reduced as parameters are added to a model, but this increases the variance (Burnham and Anderson, 2002). Thus, the principle of parsimony attempts to find a balance between the fit of the model and the number of parameters required. Several measures of parsimony can be used for this assessment. We selected the commonly used Akaike Information Criterion with an adjustment to reflect the effects of sample size (AICc). Models are compared based on the differences in the AICc values. Unlike in the null hypothesis testing statistical framework, there is no strict cutoff representing "significance" between models, and in fact, the method does not determine significance at all. Alternatively, support for differences between hypotheses, based on the data and the models, increases with difference in AICc between competing models. Burnham and Anderson (2002) suggest that when AICc values differ by less than 2 units the support for one hypothesis over another is not meaningfully different based on the data and models considered. They also suggest that differences of 4-7 indicate considerably less support for the model with the greater AICc and those greater than 10 indicate essentially no support for the model with the greater AICc. We will use the terms "no" or "weak" support, "moderate" support, and "strong" support for models differing by no more than 2 units, more than 2, and as much as 7 units, or more than 7 units, respectively. 
Table 2. Variables used in analyses of the survival of fish passing turbines.

[The Application column indicates which of the treatment groups the variables were applied to. Fish weight was used as a secondary variable instead of tag burden after all other variables were evaluated, due to their close association. The first model evaluated (global model) included all possible interactions among group covariates plus the other variables and interactions listed. A linear function between survival and each variable was used except for head and turbine discharge, for which linear and quadratic functions were used. km, kilometer; yyyy 4-digit year format; Trt, treatment; Turq, turbine discharge; Persp, percentage spill; Turbloc, turbine unit location]

\begin{tabular}{|c|c|c|c|c|}
\hline Type & Name & Definition & Application & Note \\
\hline Group & Photo & Day (0) or night (1) & Both & \\
\hline Group & Gated & Distance to first detection site $(\mathrm{km})$ & Both & \\
\hline Group & Year & yyyy & Both & \\
\hline Group & Trt & Control (0) or turbine (1) & Both & \\
\hline Group & Reach & River reach & Both & \\
\hline Operational & Totq & Total discharge & Control & \\
\hline Operational & Head (linear) & Forebay elevation minus tailwater elevation & Turbine & Linear \\
\hline Operational & Head (quadratic) & Forebay elevation minus tailwater elevation & Turbine & Quadratic \\
\hline Operational & Turq (linear) & Unit discharge & Turbine & Linear \\
\hline Operational & Turq (quadratic) & Unit discharge & Turbine & Quadratic \\
\hline Operational & Turbloc & Unit number, or south (0) \& north (1) & Turbine & \\
\hline Operational & Persp & (Spill discharge / total discharge) $* 100$ & Both & \\
\hline Biological & Tagb & Tag burden percent & Both & Primary \\
\hline Biological & Weight & Fish weight & Both & Secondary \\
\hline Biological & Temp & Tailrace water temp & Both & \\
\hline Interaction & Turbloc*photo & Turbloc*photo & Turbine & Predation \\
\hline Interaction & Trt*photo & Trt*photo & Both & \\
\hline Interaction & Persp*trt & Persp*trt & Both & \\
\hline Interaction & Tagb*year & Tagb*year & Both & \\
\hline Interaction & Tagb*trt & Tagb*trt & Both & \\
\hline Interaction & Temp*trt & Temp*trt & Both & \\
\hline Interaction & Temp*yr & Temp*yr & Both & \\
\hline Interaction & Other & All possible group interactions & Both & $\begin{array}{l}\text { Only in } \\
\text { global model }\end{array}$ \\
\hline
\end{tabular}


One must cautiously evaluate models when AICc differences are within about 0-2 units per unit difference in parameter number, because the larger-parameter model may seem to have support from the data only because it is similar to the supported reducedparameter model. As indicated in equation 1, in the absence of a change in the deviance $(-2 \log L(\hat{\Theta}))$, which represents the fit of the model to the data, AICc increases by 2 for each added parameter. In these cases, the additional variable is sometimes called a "pretender" variable. The analyses in this report contain many comparisons of models differing by one parameter, which are simple to evaluate in this context. The AICc is calculated as

$$
A I C c=-2 \log L(\hat{\Theta})+2 K+\frac{2 K(K+1)}{n-K-1}
$$

where $L(\hat{\Theta})$ is the maximized likelihood for the model, $K$ is the number of estimable parameters in the model, and $n$ is the sample size.

The analyses were done using Program MARK (White and Burnham, 1999). A recaptures-only data type with a logit link was used in each analysis. Each analysis began with a "full model" consisting of all group covariates and interactions among them, plus the full suite of individual covariates and interactions listed in table 2. Survival and recapture probabilities are inseparable in the last reach, although in the MARK software their joint probability $(\lambda)$ is divided between estimates of survival and recapture. We fixed the value of the survival estimate in the last reach to 1.0 so that an estimate of $\lambda$ was reflected in the estimate of recapture probability. We also fixed survival or recapture probabilities to 1.0 and reduced the number of estimated parameters accordingly in cases where the data indicated all fish in the sample survived or were detected.

The full model was used as a basis for modifications of parameters describing recapture probabilities to determine the most parsimonious model of recapture probabilities for use in all other comparisons. Five models of recapture probabilities were evaluated including models with group, reach, multiplicative and additive combinations of group and reach, and the intercept only. In the event that more than one model of recapture probability was supported by the data, we selected the most parameterized model for use in subsequent analyses.

The analyses were conducted following an a priori order of variable removal and evaluation (table 3 ). This strategy is consistent with the principles of information theoretic analyses and parsimony. The premise behind the order was to evaluate for removal the interaction effects and as many group and biological covariates as possible prior to evaluating the operational covariates, so that the effects of the operational covariates would not be affected by evaluation within a series of potentially over-fitted models. The exception to this convention was the covariate of tag burden and the treatment*tag burden interaction, which we purposely left in the models to control for any effects until after the operational covariates were evaluated. This decision was based on laboratory results of Brown and others (2009) indicating tag burden was an important factor in survival and injury of tagged fish after simulated turbine passage. 


\section{Table 3. A priori order of covariate evaluations.}

[Group covariates included treatment, photoperiod, and year. Individual covariates included tag burden, spill percentage, turbine passage location, turbine discharge, head, and total discharge. Interactions between treatment and tag burden and spill percentage were used to examine the potential differential effects of tag burden and spill percentage on turbine and control fish. The effect of total discharge was applied only to control fish (treatment $=0$ ) and the effects of turbine location, head, and turbine unit discharge were applied only to turbine fish (treatment $=1$ ). A tag burden and year interaction was included to address the potential effect of different tag types on the tag burden effect. A turbine passage location and photoperiod interaction was included to determine potential effects of photoperiod on the effect of passage location that might be related to predation. Each covariate or interaction was evaluated in the order listed]

Group covariates and all possible interactions, plus individual covariates and selected interactions.

Tag burden and year interaction.

Temperature and year interaction.

Year effect.

Turbine passage location and photo period interaction.

Photoperiod and treatment interaction.

Temperature and treatment interaction.

Photoperiod effect.

Temperature effect.

Spill percentage and treatment interaction.

Total discharge effect.

Main spill percentage effect.

Main turbine passage location effect.

Linear head effect.

Quadratic head effect.

Linear turbine unit discharge effect.

Quadratic turbine unit discharge effect.

Tag burden and treatment interaction.

Distance to first gate effect (McNary only).

Tag burden effect. 


\section{Results of Analyses from Studies at John Day Dam}

\section{Yearling Chinook Salmon}

\section{Environmental Conditions}

The ranges of the individual covariates at the times of fish passage were similar between years. The turbines were usually operated within 1 percent of the peak turbine operating efficiency during the studies. The turbine unit discharge ranged from 11.4 to 22.2 thousand $\mathrm{ft}^{3} / \mathrm{s}$ (fig. 1). A summary of covariate values at the times of fish passage is shown in appendix A and covariate daily averages are presented in figure 2 . Total discharge ranged from 138.9 to 372.4 thousand $\mathrm{ft}^{3} / \mathrm{s}$, with a median of 227.7 thousand $\mathrm{ft}^{3} / \mathrm{s}$. The hydraulic head ranged from 97.0 to $104.5 \mathrm{ft}$, with a median of $101.6 \mathrm{ft}$. Spill percentages were generally according to the designed operation tests in each year, but were as high as 73.7 percent. Tag burden ranged from 1.23 to 8.92 percent, with a median of 4.53 percent. Water temperature ranged from 9.70 to $15.44{ }^{\circ} \mathrm{C}$, with a median of $12.17^{\circ} \mathrm{C}$.

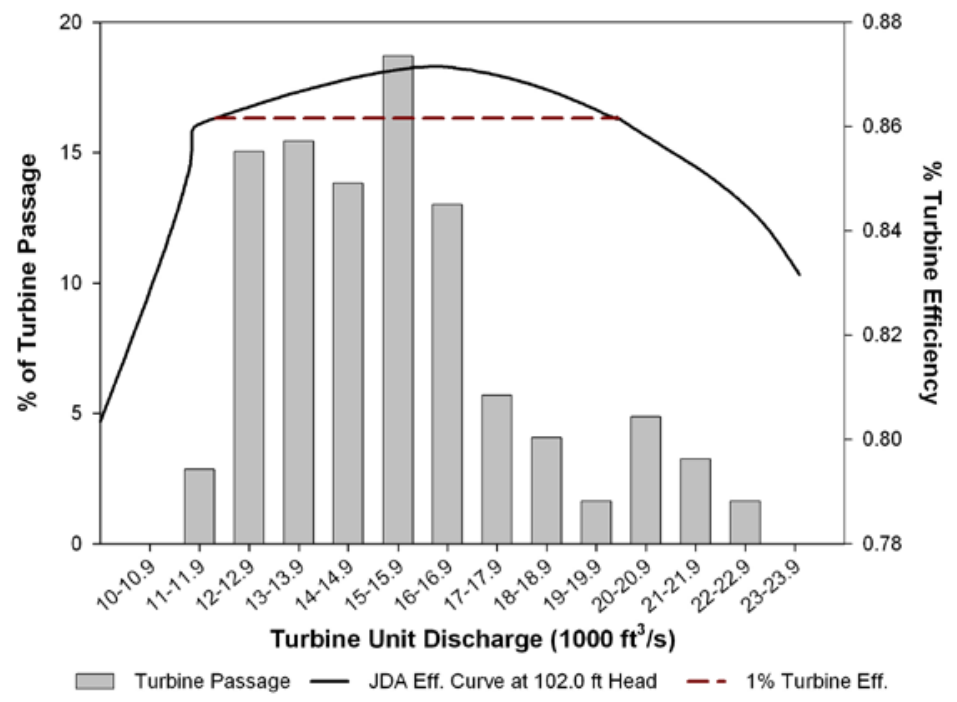

Figure 1. Graph showing turbine unit discharges during yearling Chinook salmon passage (bars) and turbine efficiency (solid line) from data used in studies at John Day Dam in 2002 and 2003. The discharges bounded by the dashed line are within 1 percent of the peak turbine efficiency at a head of 102 feet. 

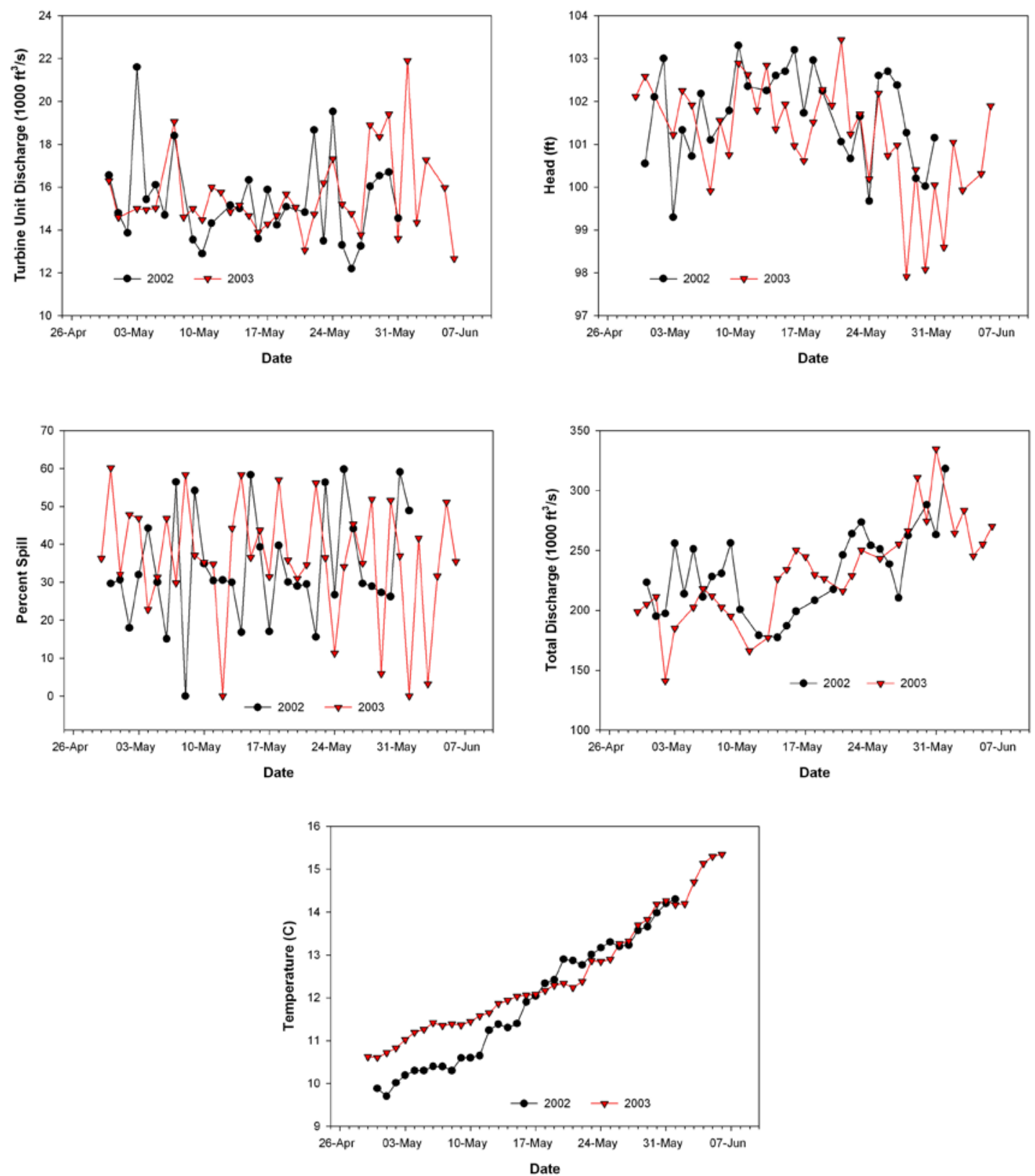

Figure 2. Graph showing daily-averaged covariate values for yearling Chinook salmon from data used in studies at John Day Dam in 2002 and 2003. 


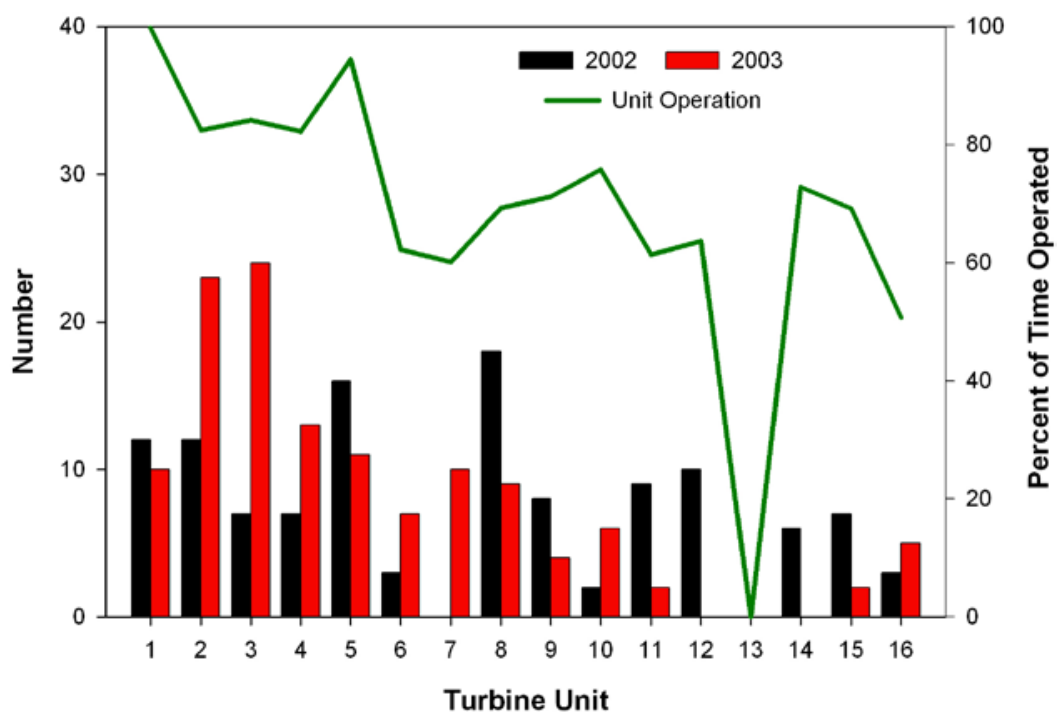

Figure 3. Graph showing number of yearling Chinook salmon passing through each turbine by year (bars) and the percentage of time each turbine was operated (line) from data used in studies at John Day Dam in 2002 and 2003.

Fish passage was present at most turbine units in at least 1 year except for unit 13 (fig. 3). Fewer fish passed through higher-numbered units (northern) than lower numbered units (southern), particularly in 2003, indicating that passage was generally higher in units near the Oregon shoreline. Fish passage location generally coincided with unit operation. Similar numbers of fish passed turbines in $2002(N=120)$ and $2003(N=$ 126).

\section{Survival}

The analyses of factors affecting survival were based on 246 fish in the turbine group and 2,973 fish in the control group. Nearly three times as many fish were in the control group at night in $2003(N=1,562)$ than in the other groups of year, treatment, and photoperiod (appendix B).

Correlation analyses indicated that several variables were highly related. Pearson correlation coefficients greater than an absolute value of $0.8(|0.8|)$ indicated that the separate influences of several pairs of variables could be difficult to determine if they were used together (tables 4 and 5; Belsley and others, 1980). These include the pairs head and total discharge, head and turbine discharge, tag burden and fish weight, percentage of spill and powerhouse discharge, and percentage of spill and photoperiod. The last pair was expected to be correlated because the dam operations were being tested during the original studies. Analyses of multicollinearity indicated that few dependencies among the variables would result from these correlations, although there would be some inflation of parameter variances if total discharge and head were used together. However, we had planned to apply only total discharge to the control group and head to the turbine group, so no difficulties were expected from these correlations. Fish weight and tag burden were not examined for multicollinearity because they likely would not be used 
together due to their high bivariate correlation coefficient $(>|0.9|)$. Based on these results, tag burden and fish weight were not used in models together. If the data and models supported an effect of tag burden, it was replaced with fish weight during post-hoc analyses to determine which factor was better supported.

A single model of recapture probabilities was supported by the data. The multiplicative model of group and reach (model 1 in appendix C) received more than 99 percent of the AICc weight, indicating that it was the only model supported by the data. This model of recapture probabilities was used in all comparisons of effects on survival. Visual examination of the capture histories (appendix B) indicated all fish in the turbine group passing the dam during the night in 2002 and 2003 were detected at the first downstream site, so these parameters were fixed to 1.0 in the analyses. In subsequent analyses (model 17 from table 6), the recapture probabilities at the first downstream site ranged from 0.666 (SE 0.020) to 0.870 (SE 0.009), and averaged 0.761. The $\lambda$ term ranged from 0.708 (SE 0.056) to 1.0 (manually fixed for analysis), and averaged 0.980 .

Few of the covariates examined were supported as determinants of survival in these data. Only water temperature and tag burden were supported by the data and models (table 6). The operational covariates contributed little to the fit of the models, as indicated by the similarities in deviances between competing models (for example, model 12 with total discharge compared to model 11 without it). Additionally, most models differed by a single parameter and in every case the difference in AICc values between models with and without each operational covariate changed by $0-2$ units for each unit difference in the number of parameters, indicating that the covariates added little to the model fit. Linear effects require one parameter to describe and two parameters for those with a quadratic effect (the linear term and the squared term); therefore, for a factor with even a small effect one would expect a delta AICc of at least 2 for a linear effect ( 2 times the number of parameters to describe the effect) and at least 4 for a factor with a quadratic effect. For example, the AICc of the model with a linear effect of head (model 14) was 1.6 greater than the model without a linear effect of head (model 15) and the model with the quadratic effect of head (model 14a) was 3.7 greater than the model without that parameter. The AICc of the model with a linear effect of turbine discharge (model 15) was 1.6 greater than the model without that effect (model 16) and the AICc of the model with a quadratic effect of turbine unit discharge (model 15a) was 3.5 greater than the model without turbine unit discharge. These results indicated that effects of the operational covariates were not supported. The only model of survival supported by the data included the group covariates of treatment and year plus the individual covariates of water temperature and tag burden (model 17 in table 6).

A positive effect of water temperature on survival was supported. When water temperature was removed, the delta AICc increased by 10 units (model 9 compared to model 10 in table 6), indicating that it was strongly supported. The model slopes indicate a greater temperature effect on turbine fish than control fish (table 7, fig. 4). The estimated survival of the control group was higher than the turbine group, as expected. 
Table 4. Correlation indices of data from yearling Chinook salmon from the turbine group from data used in studies at John Day Dam in 2002 and 2003.

[Pearson correlation coefficients are listed above the probabilities of obtaining a greater value under the hypothesis that $\mathrm{Rho}=0$. Sample size is 246 ; <, less than; see table 2 for variable name definitions]

\begin{tabular}{|c|c|c|c|c|c|c|c|c|c|}
\hline & TOTQ & PER_SPI & HEAD & TURQ & UNITLOC & РНОТО & TEMP & WEIGHT & $\begin{array}{c}\text { TAG } \\
\text { BURDEN }\end{array}$ \\
\hline \multirow[t]{2}{*}{ TOTQ } & 1.0000 & -0.0831 & -0.8584 & 0.5075 & -0.0374 & 0.1081 & 0.4566 & -0.0089 & 0.0234 \\
\hline & & 0.1938 & $<0.0001$ & $<0.0001$ & 0.5593 & 0.0907 & $<0.0001$ & 0.8901 & 0.7147 \\
\hline \multirow[t]{2}{*}{ PER_SPI } & & 1.0000 & 0.4017 & -0.6509 & -0.0157 & -0.8185 & 0.1107 & 0.1678 & -0.1389 \\
\hline & & & $<0.0001$ & $<0.0001$ & 0.8070 & $<0.0001$ & 0.0831 & 0.0083 & 0.0294 \\
\hline \multirow[t]{2}{*}{ HEAD } & & & 1.0000 & -0.6930 & 0.1055 & -0.4002 & -0.3908 & 0.0619 & -0.0670 \\
\hline & & & & $<0.0001$ & 0.0987 & $<0.0001$ & $<0.0001$ & 0.3336 & 0.2949 \\
\hline \multirow[t]{2}{*}{ TURQ } & & & & 1.0000 & -0.0328 & 0.5749 & 0.1515 & -0.1399 & 0.1033 \\
\hline & & & & & 0.6089 & $<0.0001$ & 0.0175 & 0.0283 & 0.1062 \\
\hline \multirow[t]{2}{*}{ UNITLOC } & & & & & 1.0000 & -0.0791 & -0.1024 & 0.0749 & -0.1032 \\
\hline & & & & & & 0.2166 & 0.1091 & 0.2417 & 0.1063 \\
\hline \multirow[t]{2}{*}{ РнОTO } & & & & & & 1.0000 & -0.0502 & -0.1790 & 0.1648 \\
\hline & & & & & & & 0.4333 & 0.0049 & 0.0096 \\
\hline \multirow[t]{2}{*}{ TEMP } & & & & & & & 1.0000 & 0.0206 & 0.0055 \\
\hline & & & & & & & & 0.7476 & 0.9316 \\
\hline \multirow[t]{2}{*}{ WEIGHT } & & & & & & & & 1.0000 & -0.9225 \\
\hline & & & & & & & & & $<0.0001$ \\
\hline
\end{tabular}

A negative effect of tag burden was also strongly supported. The a priori order of variable assessment would have resulted in model 16 being the best-supported model, but close inspection indicated it was over parameterized. The tag burden and tag burden*treatment interaction in model 16 were of similar size, but of opposite sign, indicating the net effect may have been only on the control group. Model 17 includes a tag burden effect only on the control fish, is more supported than model 16 by a difference of 2 AICc units, and differs by a single parameter. This indicates the treatment*tag burden interaction term in model 16 is not contributing to the fit of the model, and model 17 is better supported. Model 17 represents the hypothesis that tag burden is a factor only for the control group. Removing this effect results in an increase in AICc of more than 20 units (model 17compared with model 18), indicating it is a strongly supported effect. It also indicates that the effect of tag burden on survival of the control group is negative (table 7, fig. 4). 
As a final comparison, model 17 was altered by replacing the tag burden covariate with fish weight. This model (19) differed from model 17 by an increase of nearly 9 AICc units, has the same number of parameters, and is not supported. Thus, despite the high correlation between tag burden and fish weight $(\mathrm{r}=-0.9225)$, the data and models strongly support the effect on survival being due to tag burden.

Table 5. Correlation indices of data from yearling Chinook salmon from the control group from data used in studies at John Day Dam in 2002 and 2003.

[Pearson correlation coefficients are listed above the probabilities of obtaining a greater value under the hypothesis that $\mathrm{Rho}=0$. Sample size is 2,$973 ;<$, less than; see table 2 for variable name definitions]

\begin{tabular}{|c|c|c|c|c|c|c|}
\hline & TOTQ & PER_SPI & РнОто & TEMP & WEIGHT & $\begin{array}{c}\text { TAG } \\
\text { BURDEN }\end{array}$ \\
\hline TOTQ & 1.0000 & $\begin{array}{r}-0.0538 \\
0.0034\end{array}$ & $\begin{array}{l}0.0095 \\
0.6046\end{array}$ & $\begin{array}{r}0.5916 \\
<0.0001\end{array}$ & $\begin{array}{r}-0.0165 \\
0.3697\end{array}$ & $\begin{array}{l}0.0408 \\
0.0261\end{array}$ \\
\hline PER_SPI & & 1.0000 & $\begin{array}{l}-0.8768 \\
<0.0001\end{array}$ & $\begin{array}{l}0.0442 \\
0.0159\end{array}$ & $\begin{array}{r}-0.0295 \\
0.1077\end{array}$ & $\begin{array}{l}0.0301 \\
0.1007\end{array}$ \\
\hline РНОТО & & & 1.0000 & $\begin{array}{r}-0.0272 \\
0.1380\end{array}$ & $\begin{array}{l}0.0036 \\
0.8461\end{array}$ & $\begin{array}{l}0.0026 \\
0.8858\end{array}$ \\
\hline TEMP & & & & 1.0000 & $\begin{array}{r}-0.0449 \\
0.0144\end{array}$ & $\begin{array}{r}0.0852 \\
<0.0001\end{array}$ \\
\hline WEIGHT & & & & & 1.0000 & $\begin{array}{l}-0.9190 \\
<0.0001\end{array}$ \\
\hline
\end{tabular}


Table 6. Model-selection results of data from radio-tagged yearling Chinook salmon used in studies at John Day Dam in 2002 and 2003.

[Presence of a factor in a model is indicated by an ' $x$ ' in the column for that factor. Model 1 was a global model including all group covariates and their interactions (g) as well as all individual covariates and interactions listed. All models shared a common $\mathrm{g} *$ reach model of recapture probability. $\mathrm{K}$ indicates the number of parameters. The tag burden covariate was applied only to the control group in model 17. An asterisk after the model number indicates the best-supported model of the suite. See table 2 for variable name definitions]

\begin{tabular}{|c|c|c|c|c|c|c|c|c|c|c|c|c|c|c|c|c|c|c|c|c|c|c|c|c|c|c|c|c|}
\hline \multirow[b]{3}{*}{$\begin{array}{c}\text { Model } \\
\text { No. }\end{array}$} & \multirow{2}{*}{\multicolumn{9}{|c|}{ Group covariates }} & \multicolumn{16}{|c|}{ Individual covariates } & \multirow{2}{*}{\multicolumn{3}{|c|}{ Model selection results }} \\
\hline & & & & & & & & & & \multicolumn{7}{|c|}{ Biological } & \multicolumn{9}{|c|}{ Operational } & & & \\
\hline & $\begin{array}{l}\text { 덩 } \\
\text { d্ } \\
\text { * }\end{array}$ & \pm & う & $\begin{array}{l}\text { 응 } \\
\text { 을 }\end{array}$ & 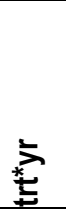 & 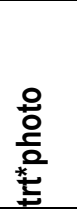 & $\begin{array}{l}\text { 옹 } \\
\frac{1}{2} \\
\frac{k}{2} \\
\frac{k}{2}\end{array}$ & 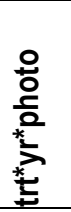 & $\begin{array}{l}\text { 엉 } \\
\mathbb{\Phi}\end{array}$ & $\xi$ & 욖 & 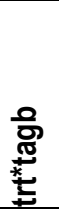 & 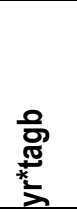 & Еِ & 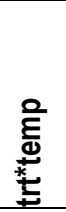 & 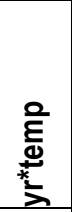 & 은 & 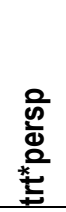 & 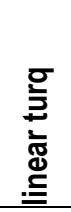 & 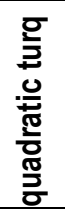 & 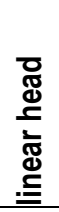 & 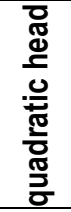 & 은 & 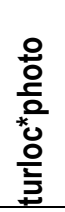 & 뭉 & AlCc & $\mathrm{K}$ & Deviance \\
\hline 1 & $\mathrm{x}$ & $\mathrm{x}$ & $x$ & $\bar{x}$ & $\mathrm{x}$ & $\mathrm{x}$ & $\mathrm{x}$ & $\mathrm{x}$ & $\bar{x}$ & & $\mathrm{x}$ & $\mathrm{x}$ & $\mathrm{x}$ & $\mathrm{x}$ & $\mathrm{x}$ & $\mathrm{x}$ & $\mathrm{x}$ & $\mathrm{x}$ & $\mathrm{x}$ & & $\mathrm{x}$ & & $\mathrm{x}$ & $\mathrm{x}$ & $\mathrm{x}$ & 4505.9 & 35 & 4435.4 \\
\hline 2 & & $\mathrm{x}$ & $\mathrm{x}$ & $\mathrm{x}$ & $\mathrm{x}$ & $\mathrm{x}$ & $\mathrm{x}$ & $\mathrm{x}$ & $\mathrm{x}$ & & $\mathrm{x}$ & $\mathrm{x}$ & $\mathrm{x}$ & $\mathrm{x}$ & $\mathrm{x}$ & $\mathrm{x}$ & $\mathrm{x}$ & $\mathrm{x}$ & $\mathrm{x}$ & & $\mathrm{x}$ & & $\mathrm{x}$ & $\mathrm{x}$ & $\mathrm{x}$ & 4491.7 & 28 & 4435.4 \\
\hline 3 & & $\mathrm{x}$ & $\mathrm{x}$ & $\mathrm{x}$ & $\mathrm{x}$ & $\mathrm{x}$ & $\mathrm{x}$ & $\mathrm{x}$ & $\mathrm{x}$ & & $\mathrm{x}$ & $\mathrm{x}$ & & $\mathrm{x}$ & $\mathrm{x}$ & $\mathrm{x}$ & $\mathrm{x}$ & $\mathrm{x}$ & $\mathrm{x}$ & & $\mathrm{x}$ & & $\mathrm{x}$ & $\mathrm{x}$ & $\mathrm{x}$ & 4490.6 & 27 & 4436.6 \\
\hline 4 & & $\mathrm{x}$ & $\mathrm{x}$ & $\mathrm{x}$ & $\mathrm{x}$ & $\mathrm{x}$ & $\mathrm{x}$ & $\mathrm{x}$ & $\mathrm{x}$ & & $\mathrm{x}$ & $\mathrm{x}$ & & $\mathrm{x}$ & $\mathrm{x}$ & & $\mathrm{x}$ & $\mathrm{x}$ & $\mathrm{x}$ & & $\mathrm{x}$ & & $\mathrm{x}$ & $\mathrm{x}$ & $\mathrm{x}$ & 4488.5 & 26 & 4436.3 \\
\hline 5 & & $\mathrm{x}$ & & $\mathrm{x}$ & & $\mathrm{x}$ & & & $\mathrm{x}$ & & $\mathrm{x}$ & $\mathrm{x}$ & & $\mathrm{x}$ & $\mathrm{x}$ & & $\mathrm{x}$ & $\mathrm{x}$ & $\mathrm{x}$ & & $\mathrm{x}$ & & $\mathrm{x}$ & $\mathrm{x}$ & $\mathrm{x}$ & 4484.7 & 22 & 4440.6 \\
\hline 6 & & $\mathrm{x}$ & & $\mathrm{x}$ & & $\mathrm{x}$ & & & $\mathrm{x}$ & & $\mathrm{x}$ & $\mathrm{x}$ & & $\mathrm{x}$ & $\mathrm{x}$ & & $\mathrm{x}$ & $\mathrm{x}$ & $\mathrm{x}$ & & $\mathrm{x}$ & & $\mathrm{x}$ & & $\mathrm{x}$ & 4483.6 & 21 & 4441.4 \\
\hline 7 & & $\mathrm{x}$ & & $\mathrm{x}$ & & & & & $\mathrm{x}$ & & $\mathrm{x}$ & $\mathrm{x}$ & & $\mathrm{x}$ & $\mathrm{x}$ & & $\mathrm{x}$ & $\mathrm{x}$ & $\mathrm{x}$ & & $\mathrm{x}$ & & $\mathrm{x}$ & & $\mathrm{x}$ & 4482.5 & 20 & 4442.4 \\
\hline 8 & & $\mathrm{x}$ & & $\mathrm{x}$ & & & & & $\mathrm{x}$ & & $\mathrm{x}$ & $\mathrm{x}$ & & $\mathrm{x}$ & & & $\mathrm{x}$ & $\mathrm{x}$ & $\mathrm{x}$ & & $\mathrm{x}$ & & $\mathrm{x}$ & & $\mathrm{x}$ & 4482.8 & 19 & 4444.6 \\
\hline 9 & & $\mathrm{x}$ & & & & & & & $\mathrm{x}$ & & $\mathrm{x}$ & $\mathrm{x}$ & & $\mathrm{x}$ & & & $\mathrm{x}$ & $\mathrm{x}$ & $\mathrm{x}$ & & $\mathrm{x}$ & & $\mathrm{x}$ & & $\mathrm{x}$ & 4481.2 & 18 & 4445.1 \\
\hline 10 & & $\mathrm{x}$ & & & & & & & $\mathrm{x}$ & & $\mathrm{x}$ & $\mathrm{x}$ & & & & & $\mathrm{x}$ & $\mathrm{x}$ & $\mathrm{x}$ & & $\mathrm{x}$ & & $\mathrm{x}$ & & $\mathrm{x}$ & 4491.2 & 17 & 4457.1 \\
\hline 12 & & $\mathrm{x}$ & & & & & & & $\mathrm{x}$ & & $\mathrm{x}$ & $\mathrm{x}$ & & $\mathrm{x}$ & & & $\mathrm{x}$ & & $\mathrm{x}$ & & $\mathrm{x}$ & & $\mathrm{x}$ & & & 4477.8 & 16 & 4445.8 \\
\hline 13 & & $\mathrm{x}$ & & & & & & & $\mathrm{x}$ & & $\mathrm{x}$ & $\mathrm{x}$ & & $\mathrm{x}$ & & & & & $\mathrm{x}$ & & $\mathrm{x}$ & & $\mathrm{x}$ & & & 4476.3 & 15 & 4446.2 \\
\hline 14 & & $\mathrm{x}$ & & & & & & & $\mathrm{x}$ & & $\mathrm{x}$ & $\mathrm{x}$ & & $\mathrm{x}$ & & & & & $\mathrm{x}$ & & $\mathrm{x}$ & & & & & 4474.9 & 14 & 4446.9 \\
\hline $14 \mathrm{a}$ & & $\mathrm{x}$ & & & & & & & $\mathrm{x}$ & & $\mathrm{x}$ & $\mathrm{x}$ & & $\mathrm{x}$ & & & & & $\mathrm{x}$ & & & $\mathrm{x}$ & & & & 4477.0 & 15 & 4446.9 \\
\hline 15 & & $\mathrm{x}$ & & & & & & & $\mathrm{x}$ & & $\mathrm{x}$ & $\mathrm{x}$ & & $\mathrm{x}$ & & & & & $\mathrm{x}$ & & & & & & & 4473.3 & 13 & 4447.3 \\
\hline $15 \mathrm{a}$ & & $\mathrm{x}$ & & & & & & & $\mathrm{x}$ & & $\mathrm{x}$ & $\mathrm{x}$ & & $\mathrm{x}$ & & & & & & $\mathrm{x}$ & & & & & & 4475.2 & 14 & 4447.2 \\
\hline 16 & & $\mathrm{x}$ & & & & & & & $\mathrm{x}$ & & $\mathrm{x}$ & $\mathrm{x}$ & & $\mathrm{x}$ & & & & & & & & & & & & 4471.7 & 12 & 4447.7 \\
\hline $17 *$ & & $\mathrm{x}$ & & & & & & & $\mathrm{x}$ & & $\mathrm{x}$ & & & $\mathrm{x}$ & & & & & & & & & & & & 4469.7 & 11 & 4447.7 \\
\hline 18 & & $\mathrm{x}$ & & & & & & & $\mathrm{x}$ & & & & & $\mathrm{x}$ & & & & & & & & & & & & 4490.0 & 10 & 4470.0 \\
\hline 19 & & $\mathrm{x}$ & & & & & & & $\mathrm{x}$ & $\mathrm{x}$ & & & & $\mathrm{x}$ & & & & & & & & & & & & 4478.5 & 11 & 4456.5 \\
\hline
\end{tabular}


Table 7. Beta (slope) coefficients of estimable survival parameters of yearling Chinook salmon from data used in studies at John Day Dam in 2002 and 2003.

[The data are from model 17 in table 6; Beta, slope coefficient]

\begin{tabular}{lcccc}
\hline \multicolumn{1}{c}{ Parameter } & Beta & Standard & \multicolumn{2}{c}{95 percent confidence } \\
Lerror & Lower & Upper \\
\hline Intercept & 1.959324 & 1.180059 & -0.353590 & 4.272239 \\
Treatment group & -3.862740 & 0.603389 & -5.045380 & -2.680100 \\
Tag burden for control group & -0.480580 & 0.103616 & -0.683670 & -0.277490 \\
Temperature & 0.333017 & 0.090592 & 0.155456 & 0.510577 \\
\hline
\end{tabular}
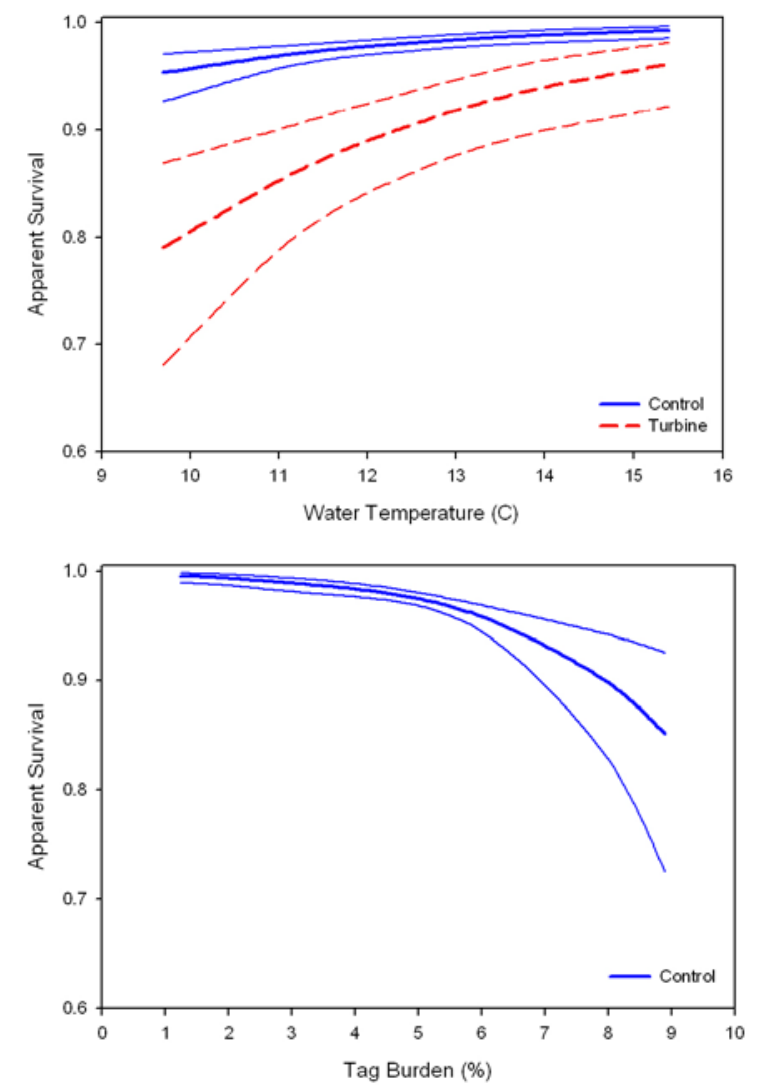

Figure 4. Graph showing estimated effects of water temperature (upper plate) and tag burden (lower plate) on apparent survival of yearling Chinook salmon from data used in studies at John Day Dam in 2002 and 2003. Predictions (thick lines) and 95 percent confidence intervals (thin lines) from model 17 in table 6 are plotted. Note that the effect of tag burden was only supported for fish in the control group. 


\section{Key Findings in Data from Yearling Chinook Salmon at John Day Dam}

- The data set included 246 fish in the turbine group and 2,973 fish in the control group.

- Most data were collected at turbine discharges within 1 percent of peak unit efficiency.

- Operational covariates were not supported as factors affecting turbine passage survival.

- A positive effect of water temperature on survival was strongly supported.

- A negative effect of tag burden on survival was strongly supported for the control group. There was strong support that this effect was due to tag burden rather than fish weight. An effect of tag burden was not supported for the turbine group.

\section{Subyearling Chinook Salmon}

\section{Environmental Conditions}

The environmental conditions occurring during passage of subyearling Chinook salmon at John Day Dam differed between years. The differences between years were related to discharge and water temperature. As in the spring, the turbines were generally operated within 1 percent of peak efficiency during fish passage (fig. 5). Overall turbine unit discharge ranged from 9.7 to 22.7 thousand $\mathrm{ft}^{3} / \mathrm{s}$ with a median of 14.7 thousand $\mathrm{ft}^{3} / \mathrm{s}$ and was higher in 2003 than in 2002. The turbine unit discharge ranged from 11.9 to 22.7 thousand $\mathrm{ft}^{3} / \mathrm{s}$ in 2002 and 9.7 to 20.9 thousand $\mathrm{ft}^{3} / \mathrm{s}$ in 2003 . Covariate values at the time of passage are summarized in appendix D and daily averages are shown in fig. 6 . The median head was $102.70 \mathrm{ft}$ (range 97.00 to $105.65 \mathrm{ft}$ ) and was similar between years. The median total discharge was 194.70 thousand $\mathrm{ft}^{3} / \mathrm{s}$ (range 89.90 to 396.20 thousand $\mathrm{ft}^{3} / \mathrm{s}$ ), but differed between years. In 2002, the median total discharge was 253.90 thousand $\mathrm{ft}^{3} / \mathrm{s}$ (range 157.70 to 396.20 thousand $\mathrm{ft}^{3} / \mathrm{s}$ ) and in 2003 it was 152.20 (range 89.90 to 237.40 thousand $\mathrm{ft}^{3} / \mathrm{s}$ ). Additionally, total discharge was 7 percent greater during the day than at night in 2002 and 6 percent greater during the day than at night in 2003. The percentage of spill also differed between years per the planned studies in 2002 and 2003 . The median tag burden was 5.35 percent (range 1.67 to 7.33 percent) and was similar between years and day/night periods. The water temperature was higher in 2003 than in 2002, particularly in July. The medians were $17.60^{\circ} \mathrm{C}$ (range 15.90 to $20.30^{\circ} \mathrm{C}$ ) in 2002 and $18.44{ }^{\circ} \mathrm{C}$ (range 16.33 to $21.61^{\circ} \mathrm{C}$ ) in 2003 . The data included fish passing through all 16 units (fig. 7). In 2002, the passage was similar among units, but in 2003, most passage was through units 1-5. Location of passage coincided with unit operation. There were 249 fish in the turbine group in 2002 and 547 in 2003, so most fish passage in the overall data set was through units $1-5$. 


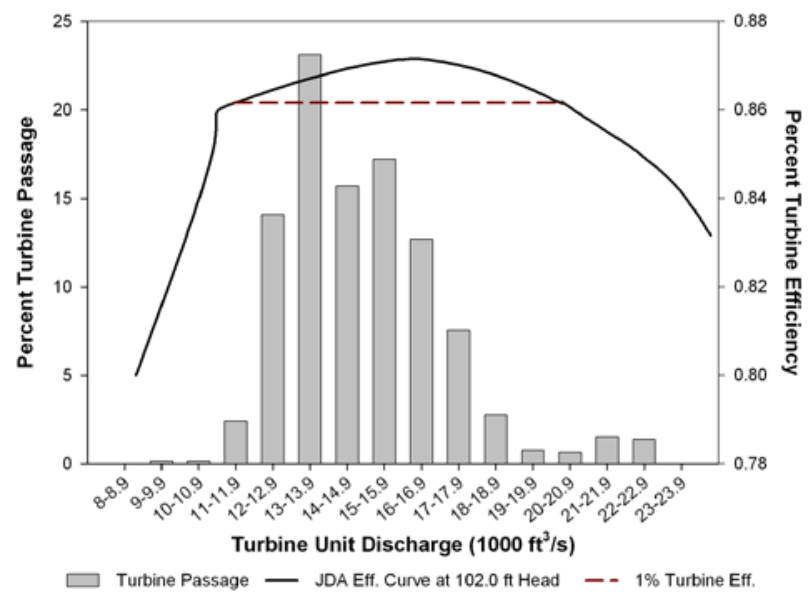

Figure 5. Graph showing turbine unit discharges during subyearling Chinook salmon passage (bars) and turbine efficiency (solid line) from data used in studies at John Day Dam in 2002 and 2003. The discharges bounded by the dashed line are within 1 percent of the peak turbine efficiency at a head of 102 feet.

\section{Survival}

Analyses of survival were based on 796 fish in the turbine group and 5,463 fish in the control group. Sample sizes among groups of treatment, year, and photoperiod were generally similar within treatment groups, with 115-318 treatment fish and 1,150-1,499 control fish per group (appendix E). Results of bivariate correlation and multicollinearity analyses were similar to those from yearling Chinook salmon (tables 8 and 9). Total discharge was applied only to the control group, head was applied only to the treatment group, and tag burden and fish weight were not used in models together.

Two of the five models of recapture probabilities were supported by the data and the more general of the two was selected for use in subsequent analyses (appendix F). The full model, which allows recapture probabilities to vary among all combinations of group and reach, and the additive model of group and reach in which recapture probabilities vary among groups and reach in a similar manner, were the only models supported by the data. Their AICc values were identical and were at least 909 units smaller than those of the other models evaluated. The recapture probabilities at the first downstream site estimated from the more general model (model 18 in table 10) ranged from 0.466 (SE 0.015) to 0.957 (SE 0.015) and averaged 0.757. The $\lambda$ term ranged from 0.948 (SE 0.006) to 0.993 (SE 0.002), and averaged 0.972. 

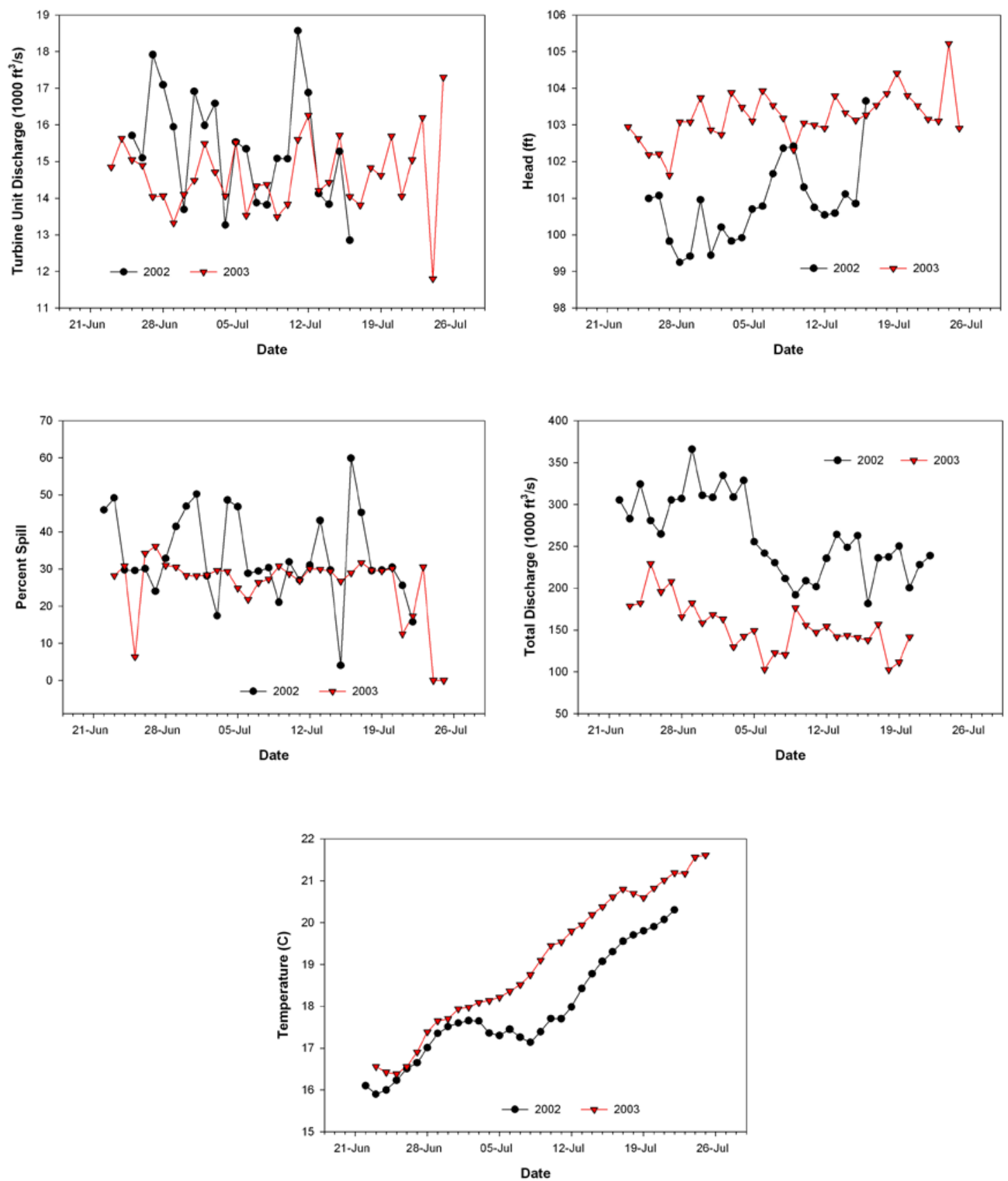

Figure 6. Graph showing daily-averaged covariate values for subyearling Chinook salmon used in analyses of survival from data used in studies at John Day Dam in 2002 and 2003. 


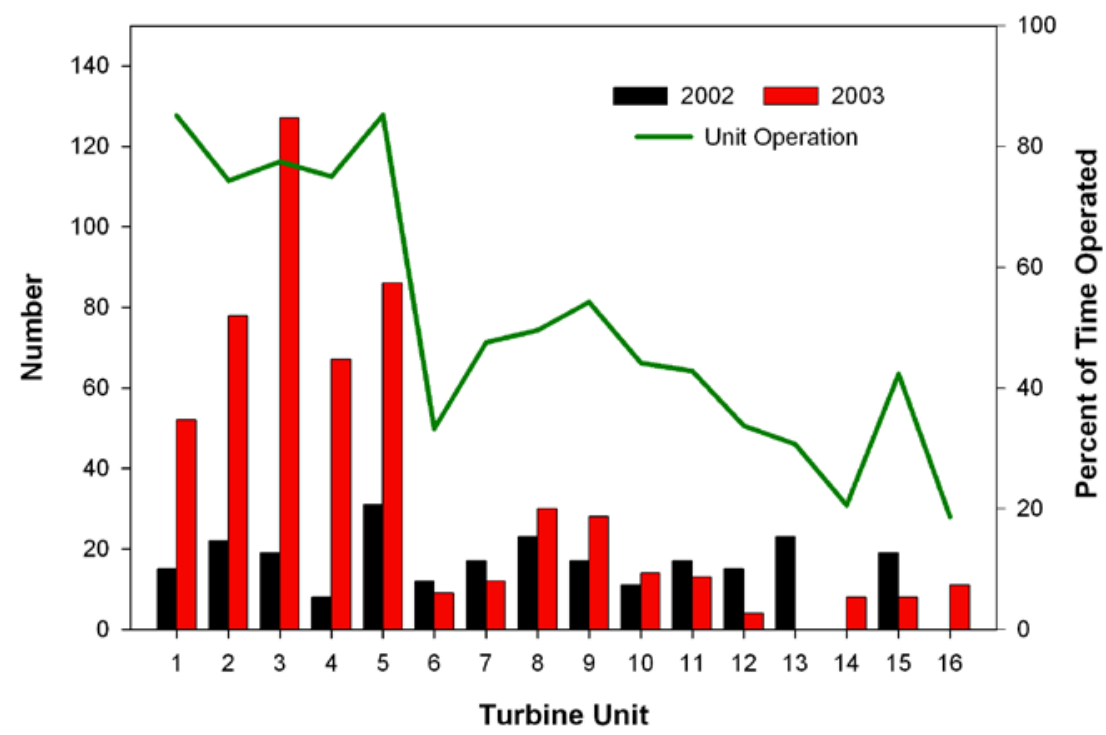

Figure 7. Graph showing number of subyearling Chinook salmon passing through each turbine by year (bars) and the percentage of time each turbine was operated (line) from data used in studies at John Day Dam in 2002 and 2003.

Survival effects of several group covariates and one individual covariate were supported by the data and the models. Effects of treatment, year, photoperiod, reach, temperature, several interactions between these variables, and a quadratic effect of turbine unit discharge were supported (table 10). Models 5-5d evaluated several hypotheses about the effects of year. The models with linear and quadratic effects of head had AICc values 1.3 and 1.4 units greater than models without head, indicating the effects were not supported (models 14 and 14a compared to model 15). The model with a linear effect of turbine unit discharge (model 15) had an AICc value 2.0 greater than the model without turbine unit discharge (model 16), indicating that it was not a supported effect.

An effect of water temperature was supported. The model with the year*temperature interaction term (model 3 in table 10) had an AICc value about 22 units smaller than the AICc value of the model without this term (model 4) indicating that this effect was strongly supported by the data. The treatment* temperature interaction term was weakly supported by the data, as indicated by the 1-unit AICc reduction when the term was in the model (model 7 compared to model 8). Model 9, with the temperature main effect, had an AICc value about 4 units lower than model 10 without the effect, indicating moderate support for the factor. The most parsimonious model, model 18 in table 10, indicates that the effects of temperature were positive for control and turbine fish in 2002, had little effect on control fish in 2003, and were negative for turbine fish in 2003. Figure 8 depicts the effects of temperature on survival of subyearling Chinook salmon based on the coefficients in table 11. The different effects between the years may be due to the lower discharge and higher temperatures during 2003 compared to 2002. Additionally, the study season ended later in 2003 than in 2002. 
Table 8. Correlation indices of data from subyearling Chinook salmon from the turbine group from data used in studies at John Day Dam in 2002 and 2003.

[Pearson correlation coefficients are listed above the probabilities of obtaining a greater value under the hypothesis that $\mathrm{Rho}=0$. Sample size is 796 ; <, less than; see table 2 for variable name definitions]

\begin{tabular}{|c|c|c|c|c|c|c|c|c|c|}
\hline & TOTQ & PER_SPI & HEAD & TURQ & TURLOC & РНОТО & TEMP & WEIGHT & $\begin{array}{c}\text { TAG } \\
\text { BURDEN }\end{array}$ \\
\hline \multirow[t]{2}{*}{ TOTQ } & 1.0000 & 0.1668 & -0.9308 & 0.4006 & 0.3314 & -0.0218 & -0.5238 & 0.0002 & -0.0064 \\
\hline & & $<0.0001$ & $<0.0001$ & $<0.0001$ & $<0.0001$ & 0.5388 & $<0.0001$ & 0.9946 & 0.8562 \\
\hline \multirow[t]{2}{*}{ PER_SPI } & & 1.0000 & 0.0289 & -0.3981 & -0.0555 & -0.5664 & -0.1202 & -0.0407 & 0.0208 \\
\hline & & & 0.4156 & $<0.0001$ & 0.1180 & $<0.0001$ & 0.0007 & 0.2520 & 0.5572 \\
\hline \multirow[t]{2}{*}{ HEAD } & & & 1.0000 & -0.5006 & -0.3198 & -0.0998 & 0.4721 & -0.0263 & 0.0206 \\
\hline & & & & $<0.0001$ & $<0.0001$ & 0.0048 & $<0.0001$ & 0.4594 & 0.5620 \\
\hline \multirow[t]{2}{*}{ TURQ } & & & & 1.0000 & 0.0610 & 0.3598 & -0.1304 & 0.0578 & -0.0329 \\
\hline & & & & & 0.0855 & $<0.0001$ & 0.0002 & 0.1032 & 0.3542 \\
\hline \multirow[t]{2}{*}{ TURLOC } & & & & & 1.0000 & -0.0499 & -0.1759 & -0.0057 & -0.0051 \\
\hline & & & & & & 0.1592 & $<0.0001$ & 0.8725 & 0.8849 \\
\hline \multirow[t]{2}{*}{ РНОТО } & & & & & & 1.0000 & 0.0697 & 0.0183 & 0.0017 \\
\hline & & & & & & & 0.0495 & 0.6071 & 0.9610 \\
\hline \multirow[t]{2}{*}{ TEMP } & & & & & & & 1.0000 & 0.2641 & -0.2849 \\
\hline & & & & & & & & $<0.0001$ & $<0.0001$ \\
\hline \multirow[t]{2}{*}{ WEIGHT } & & & & & & & & 1.0000 & -0.9600 \\
\hline & & & & & & & & & $<0.0001$ \\
\hline
\end{tabular}

A quadratic model of turbine unit discharge was weakly supported by the data. The model with the quadratic effect of turbine unit discharge (model 15a in table 10) had an AICc value 1.3 units smaller than the model without the effect (model 16), despite having two additional parameters. The model coefficients indicate an intermediate maximum survival at 15.9 thousand $\mathrm{ft}^{3} / \mathrm{s}$, with a 95 percent confidence interval (95 percent $\mathrm{CI}$ ) of $-1.7-33.7$ thousand $\mathrm{ft}^{3} / \mathrm{s}$ (fig. 8). The confidence interval spans more than the entire operating range of the turbines at John Day Dam. The range of discharges within 1 percent of peak turbine operating efficiency at John Day Dam is 12.0 to 21.6 thousand $\mathrm{ft}^{3} / \mathrm{s}$ and the peak operating efficiency is at 17.2 thousand $\mathrm{ft}^{3} / \mathrm{s}$ (at a head of 102 $\mathrm{ft}$ near the median in the data we examined). 
Table 9. Correlation indices of data from subyearling Chinook salmon from the control group from data used in studies at John Day Dam in 2002 and 2003.

[Pearson correlation coefficients are listed above the probabilities of obtaining a greater value under the hypothesis that $\mathrm{Rho}=0$. Sample size is 5,463]

\begin{tabular}{|c|c|c|c|c|c|c|}
\hline & TOTQ & PER_SPI & PHOTO & TEMP & WEIGHT & $\begin{array}{c}\text { TAG } \\
\text { BURDEN }\end{array}$ \\
\hline \multirow[t]{2}{*}{ TOTQ } & 1.0000 & 0.0428 & 0.0855 & -0.5063 & -0.0692 & 0.0759 \\
\hline & & 0.0015 & $<0.0001$ & $<0.0001$ & $<0.0001$ & $<0.0001$ \\
\hline \multirow[t]{2}{*}{ PER_SPI } & & 1.0000 & -0.6701 & -0.0487 & -0.0070 & 0.0156 \\
\hline & & & $<0.0001$ & 0.0003 & 0.6045 & 0.2480 \\
\hline \multirow[t]{2}{*}{ РНОТО } & & & 1.0000 & 0.0462 & -0.0016 & 0.0030 \\
\hline & & & & 0.0006 & 0.9080 & 0.8275 \\
\hline \multirow[t]{2}{*}{ TEMP } & & & & 1.0000 & 0.2791 & -0.3140 \\
\hline & & & & & $<0.0001$ & $<0.0001$ \\
\hline \multirow[t]{2}{*}{ WEIGHT } & & & & & 1.0000 & -0.9636 \\
\hline & & & & & & $<0.0001$ \\
\hline
\end{tabular}

Key Findings in Data from Subyearling Chinook Salmon at John Day Dam

- The data set included 796 fish in the turbine group and 5,463 fish in the control group.

- Most data were collected primarily at turbine discharges within 1 percent of peak unit efficiency.

- Turbine discharge was the only operational covariate supported as a factor affecting turbine passage survival. A curvilinear fit to the data indicated maximum turbine passage survival was at 15.9 thousand $\mathrm{ft}^{3} / \mathrm{s}$, but the estimate was imprecise and had a 95 percent confidence interval of $-1.7-$ 33.7 thousand $\mathrm{ft}^{3} / \mathrm{s}$.

- Water temperature was supported as a factor affecting survival. A difference in the effect of water temperature between the 2 years was strongly supported. The data and models indicated moderate support for a positive effect for control and turbine groups in 2002 and a negative effect for the turbine group in 2003.

- An effect of tag burden on survival was not supported. 
Table 10. Model-selection results of data from radio-tagged subyearling Chinook salmon used in studies at John Day Dam in 2002 and 2003.

[Presence of a factor in a model is indicated by an ' $x$ ' in the column for that factor. Model 1 was a global model including all group covariates and their interactions $(\mathrm{g})$ as well as all individual covariates and interactions listed. All models shared a common $\mathrm{g}$ *reach model of recapture probability. $\mathrm{K}$ indicates the number of parameters. An asterisk after the model number indicates the best-supported model of the suite. See table 2 for variable name definitions]

\begin{tabular}{|c|c|c|c|c|c|c|c|c|c|c|c|c|c|c|c|c|c|c|c|c|c|c|c|c|c|c|c|}
\hline \multirow[b]{3}{*}{$\begin{array}{c}\text { Model } \\
\text { No. }\end{array}$} & \multirow{2}{*}{\multicolumn{9}{|c|}{ Group covariates }} & \multicolumn{15}{|c|}{ Individual covariates } & \multirow{2}{*}{\multicolumn{3}{|c|}{ Model selection results }} \\
\hline & & & & & & & & & & \multicolumn{6}{|c|}{ Biological } & \multicolumn{9}{|c|}{ Operational } & & & \\
\hline & סם & \pm & 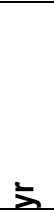 & $\begin{array}{l}\text { 응 } \\
\text { 등 }\end{array}$ & 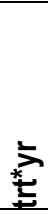 & $\begin{array}{l}\text { 응 } \\
\text { 등 } \\
\text { ț }\end{array}$ & $\begin{array}{l}\text { 옹 } \\
\frac{1}{2} \\
\text { 눈 }\end{array}$ & 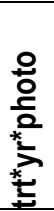 & $\begin{array}{l}\text { 덩 } \\
\text { త్ }\end{array}$ & 응 & 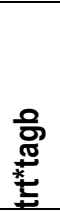 & 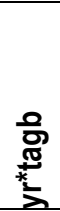 & 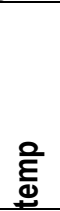 & 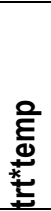 & $\frac{\text { 을 }}{\text { È }}$ & $\begin{array}{l}\text { 잉 } \\
\frac{1}{2}\end{array}$ & $\begin{array}{l}\frac{0}{0} \\
\frac{0}{2} \\
\frac{*}{5}\end{array}$ & 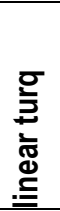 & 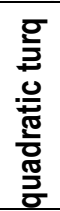 & 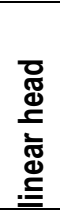 & 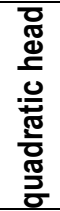 & 은 & 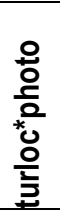 & 옹 & $\mathrm{AlCc}$ & $\mathrm{K}$ & Deviance \\
\hline 1 & $\mathrm{x}$ & $\mathrm{x}$ & $\mathrm{x}$ & $\mathrm{x}$ & $\mathrm{x}$ & $\mathrm{x}$ & $\mathrm{x}$ & $\mathrm{x}$ & $\mathrm{x}$ & $\mathrm{x}$ & $\mathrm{x}$ & $\mathrm{x}$ & $\mathrm{x}$ & $\mathrm{x}$ & $\mathrm{x}$ & $\mathrm{x}$ & $\mathrm{x}$ & $\mathrm{x}$ & & $\mathrm{x}$ & & $\mathrm{x}$ & $\mathrm{x}$ & $\mathrm{x}$ & 9175.0 & 37 & 9100.7 \\
\hline 2 & & $\mathrm{x}$ & $\mathrm{x}$ & $\mathrm{x}$ & $\mathrm{x}$ & $\mathrm{x}$ & $\mathrm{x}$ & $\mathrm{x}$ & $\mathrm{x}$ & $\mathrm{x}$ & $\mathrm{x}$ & $\mathrm{x}$ & $\mathrm{x}$ & $\mathrm{x}$ & $\mathrm{x}$ & $\mathrm{x}$ & $\mathrm{x}$ & $\mathrm{x}$ & & $\mathrm{x}$ & & $\mathrm{x}$ & $\mathrm{x}$ & $\mathrm{x}$ & 9160.9 & 30 & 9100.7 \\
\hline 3 & & $\mathrm{x}$ & $\mathrm{x}$ & $\mathrm{x}$ & $\mathrm{x}$ & $\mathrm{x}$ & $\mathrm{x}$ & $\mathrm{x}$ & $\mathrm{x}$ & $\mathrm{x}$ & $\mathrm{x}$ & & $\mathrm{x}$ & $\mathrm{x}$ & $\mathrm{x}$ & $\mathrm{x}$ & $\mathrm{x}$ & $\mathrm{x}$ & & $\mathrm{x}$ & & $\mathrm{x}$ & $\mathrm{x}$ & $\mathrm{x}$ & 9159.0 & 29 & 9100.9 \\
\hline 4 & & $\mathrm{x}$ & $\mathrm{x}$ & $\mathrm{x}$ & $\mathrm{x}$ & $\mathrm{x}$ & $\mathrm{x}$ & $\mathrm{x}$ & $\mathrm{x}$ & $\mathrm{x}$ & $\mathrm{x}$ & & $\mathrm{x}$ & $\mathrm{x}$ & & $\mathrm{x}$ & $\mathrm{x}$ & $\mathrm{x}$ & & $\mathrm{x}$ & & $\mathrm{x}$ & $\mathrm{x}$ & $\mathrm{x}$ & 9181.4 & 28 & 9125.3 \\
\hline 5 & & $\mathrm{x}$ & & $\mathrm{x}$ & & $\mathrm{X}$ & & & $\mathrm{x}$ & $\mathrm{X}$ & $\mathrm{x}$ & & $\mathrm{x}$ & $\mathrm{x}$ & $\mathrm{x}$ & $\mathrm{x}$ & $\mathrm{x}$ & $\mathrm{x}$ & & $\mathrm{x}$ & & $\mathrm{x}$ & $\mathrm{x}$ & $\mathrm{x}$ & 9194.3 & 25 & 9144.2 \\
\hline $5 a$ & & $\mathrm{x}$ & $\mathrm{x}$ & $\mathrm{x}$ & $\mathrm{x}$ & $\mathrm{x}$ & $\mathrm{x}$ & & $\mathrm{x}$ & $\mathrm{x}$ & $\mathrm{x}$ & & $\mathrm{x}$ & $\mathrm{x}$ & $\mathrm{x}$ & $\mathrm{x}$ & $\mathrm{x}$ & $\mathrm{x}$ & & $\mathrm{x}$ & & $\mathrm{x}$ & $\mathrm{x}$ & $\mathrm{x}$ & 9157.0 & 28 & 9100.9 \\
\hline $5 b$ & & $\mathrm{x}$ & $\mathrm{x}$ & $\mathrm{x}$ & $\mathrm{x}$ & $\mathrm{x}$ & & & $\mathrm{x}$ & $\mathrm{x}$ & $\mathrm{x}$ & & $\mathrm{x}$ & $\mathrm{x}$ & $\mathrm{x}$ & $\mathrm{x}$ & $\mathrm{x}$ & $\mathrm{x}$ & & $\mathrm{x}$ & & $\mathrm{x}$ & $\mathrm{x}$ & $\mathrm{x}$ & 9157.0 & 27 & 9102.8 \\
\hline $5 c$ & & $\mathrm{x}$ & $\mathrm{x}$ & $\mathrm{x}$ & & $\mathrm{x}$ & $\mathrm{x}$ & & $\mathrm{x}$ & $\mathrm{x}$ & $\mathrm{x}$ & & $\mathrm{x}$ & $\mathrm{x}$ & $\mathrm{x}$ & $\mathrm{x}$ & $\mathrm{x}$ & $\mathrm{x}$ & & $\mathrm{x}$ & & $\mathrm{x}$ & $\mathrm{x}$ & $\mathrm{x}$ & 9181.1 & 26 & 9128.9 \\
\hline $5 d$ & & $\mathrm{x}$ & & $\mathrm{x}$ & $\mathrm{x}$ & $\mathrm{x}$ & & & $\mathrm{x}$ & $\mathrm{x}$ & $\mathrm{x}$ & & $\mathrm{x}$ & $\mathrm{x}$ & $\mathrm{x}$ & $\mathrm{x}$ & $\mathrm{x}$ & $\mathrm{x}$ & & $\mathrm{x}$ & & $\mathrm{x}$ & $\mathrm{x}$ & $\mathrm{x}$ & 9183.9 & 26 & 9131.8 \\
\hline 6 & & $\mathrm{x}$ & $\mathrm{x}$ & $\mathrm{x}$ & $\mathrm{x}$ & $\mathrm{X}$ & & & $\mathrm{x}$ & $\mathrm{X}$ & $\mathrm{x}$ & & $\mathrm{X}$ & $\mathrm{X}$ & $\mathrm{X}$ & $\mathrm{x}$ & $\mathrm{X}$ & $\mathrm{X}$ & & $\mathrm{x}$ & & $\mathrm{x}$ & & $\mathrm{x}$ & 9155.0 & 26 & 9102.8 \\
\hline 7 & & $\mathrm{x}$ & $\mathrm{x}$ & $\mathrm{x}$ & $\mathrm{x}$ & & & & $\mathrm{x}$ & $\mathrm{x}$ & $\mathrm{x}$ & & $\mathrm{x}$ & $\mathrm{x}$ & $\mathrm{x}$ & $\mathrm{x}$ & $\mathrm{x}$ & $\mathrm{x}$ & & $\mathrm{x}$ & & $\mathrm{x}$ & & $\mathrm{x}$ & 9154.4 & 25 & 9104.3 \\
\hline 8 & & $\mathrm{x}$ & $\mathrm{x}$ & $\mathrm{x}$ & $\mathrm{x}$ & & & & $\mathrm{x}$ & $\mathrm{x}$ & $\mathrm{x}$ & & $\mathrm{x}$ & & $\mathrm{x}$ & $\mathrm{x}$ & $\mathrm{x}$ & $\mathrm{x}$ & & $\mathrm{x}$ & & $\mathrm{x}$ & & $\mathrm{x}$ & 9155.5 & 24 & 9107.4 \\
\hline 9 & & $\mathrm{x}$ & $\mathrm{x}$ & & $\mathrm{x}$ & & & & $\mathrm{x}$ & $\mathrm{x}$ & $\mathrm{x}$ & & $\mathrm{X}$ & $\mathrm{X}$ & $\mathrm{X}$ & $\mathrm{x}$ & $\mathrm{X}$ & $\mathrm{x}$ & & $\mathrm{x}$ & & $\mathrm{x}$ & & $\mathrm{x}$ & 9152.7 & 24 & 9104.6 \\
\hline 10 & & $\mathrm{x}$ & $\mathrm{x}$ & & $\mathrm{x}$ & & & & $\mathrm{x}$ & $\mathrm{x}$ & $\mathrm{x}$ & & & $\mathrm{x}$ & $\mathrm{x}$ & $\mathrm{x}$ & $\mathrm{x}$ & $\mathrm{x}$ & & $\mathrm{x}$ & & $\mathrm{x}$ & & $\mathrm{x}$ & 9156.9 & 23 & 9110.8 \\
\hline 11 & & $\mathrm{x}$ & $\mathrm{x}$ & & $\mathrm{x}$ & & & & $\mathrm{x}$ & $\mathrm{x}$ & $\mathrm{x}$ & & $\mathrm{x}$ & $\mathrm{x}$ & $\mathrm{x}$ & $\mathrm{x}$ & & $\mathrm{x}$ & & $\mathrm{x}$ & & $\mathrm{x}$ & & $\mathrm{x}$ & 9152.1 & 23 & 9106.0 \\
\hline 12 & & $\mathrm{x}$ & $\mathrm{x}$ & & $\mathrm{x}$ & & & & $\mathrm{x}$ & $\mathrm{x}$ & $\mathrm{x}$ & & $\mathrm{x}$ & $\mathrm{x}$ & $\mathrm{x}$ & $\mathrm{x}$ & & $\mathrm{x}$ & & $\mathrm{x}$ & & $\mathrm{x}$ & & & 9151.5 & 22 & 9107.4 \\
\hline 13 & & $\mathrm{x}$ & $\mathrm{x}$ & & $\mathrm{x}$ & & & & $\mathrm{x}$ & $\mathrm{x}$ & $\mathrm{x}$ & & $\mathrm{x}$ & $\mathrm{x}$ & $\mathrm{X}$ & & & $\mathrm{x}$ & & $\mathrm{x}$ & & $\mathrm{x}$ & & & 9150.4 & 21 & 9108.3 \\
\hline 14 & & $\mathrm{x}$ & $\mathrm{x}$ & & $\mathrm{x}$ & & & & $\mathrm{x}$ & $\mathrm{x}$ & $\mathrm{x}$ & & $\mathrm{x}$ & $\mathrm{x}$ & $\mathrm{x}$ & & & $\mathrm{x}$ & & $\mathrm{x}$ & & & & & 9148.9 & 20 & 9108.9 \\
\hline $14 \mathrm{a}$ & & $\mathrm{x}$ & $\mathrm{x}$ & & $\mathrm{x}$ & & & & $\mathrm{x}$ & $\mathrm{x}$ & $\mathrm{x}$ & & $\mathrm{x}$ & $\mathrm{x}$ & $\mathrm{x}$ & & & $\mathrm{x}$ & & & $\mathrm{x}$ & & & & 9149.0 & 21 & 9106.9 \\
\hline 15 & & $\mathrm{x}$ & $\mathrm{x}$ & & $\mathrm{x}$ & & & & $\mathrm{x}$ & $\mathrm{x}$ & $\mathrm{x}$ & & $\mathrm{x}$ & $\mathrm{x}$ & $\mathrm{x}$ & & & $\mathrm{x}$ & & & & & & & 9147.6 & 19 & 9109.5 \\
\hline $15 a$ & & $\mathrm{x}$ & $\mathrm{x}$ & & $\mathrm{x}$ & & & & $\mathrm{x}$ & $\mathrm{X}$ & $\mathrm{x}$ & & $\mathrm{x}$ & $\mathrm{x}$ & $\mathrm{x}$ & & & & $\mathrm{x}$ & & & & & & 9144.3 & 20 & 9104.3 \\
\hline 16 & & $\mathrm{x}$ & $\mathrm{x}$ & & $\mathrm{x}$ & & & & $\mathrm{x}$ & $\mathrm{x}$ & $\mathrm{x}$ & & $\mathrm{X}$ & $\mathrm{x}$ & $\mathrm{x}$ & & & & & & & & & & 9145.6 & 18 & 9109.5 \\
\hline 17 & & $\mathrm{x}$ & $\mathrm{x}$ & & $\mathrm{x}$ & & & & $\mathrm{x}$ & $\mathrm{x}$ & & & $\mathrm{x}$ & $\mathrm{x}$ & $\mathrm{x}$ & & & & $\mathrm{x}$ & & & & & & 9142.8 & 19 & 9104.7 \\
\hline $18^{*}$ & & $\mathrm{x}$ & $\mathrm{x}$ & & $\mathrm{x}$ & & & & $\mathrm{x}$ & & & & $\mathrm{x}$ & $\mathrm{x}$ & $\mathrm{x}$ & & & & $\mathrm{x}$ & & & & & & 9141.3 & 18 & 9105.2 \\
\hline
\end{tabular}


Table 11. Beta (slope) coefficients of estimable survival parameters of subyearling Chinook salmon from data used in studies at John Day Dam in 2002 and 2003.

[The data are from model 18 in table 10; Beta, slope coefficient]

\begin{tabular}{llcrc}
\hline \multicolumn{1}{c}{ Parameter } & Beta & \multicolumn{2}{c}{ Standard } & \multicolumn{2}{c}{ 95 percent confidence } \\
Intercept & -1.9540 & 1.4886 & -4.8715 & 0.9636 \\
treatment & -13.6919 & 4.7556 & -23.0128 & -4.3710 \\
year & 16.1561 & 3.3910 & 9.5097 & 22.8026 \\
treatment*year & -3.0346 & 0.5684 & -4.1488 & -1.9205 \\
temperature & 0.2752 & 0.0851 & 0.1084 & 0.4420 \\
temperature*year & -0.7767 & 0.1755 & -1.1206 & -0.4328 \\
temperature*treatment & 0.2842 & 0.1769 & -0.0626 & 0.6309 \\
turbine unit discharge & 1.0694 & 0.4497 & 0.1880 & 1.9509 \\
turbine unit discharge ${ }^{\wedge} 2$ & -0.0334 & 0.0139 & -0.0607 & -0.0062 \\
\hline
\end{tabular}



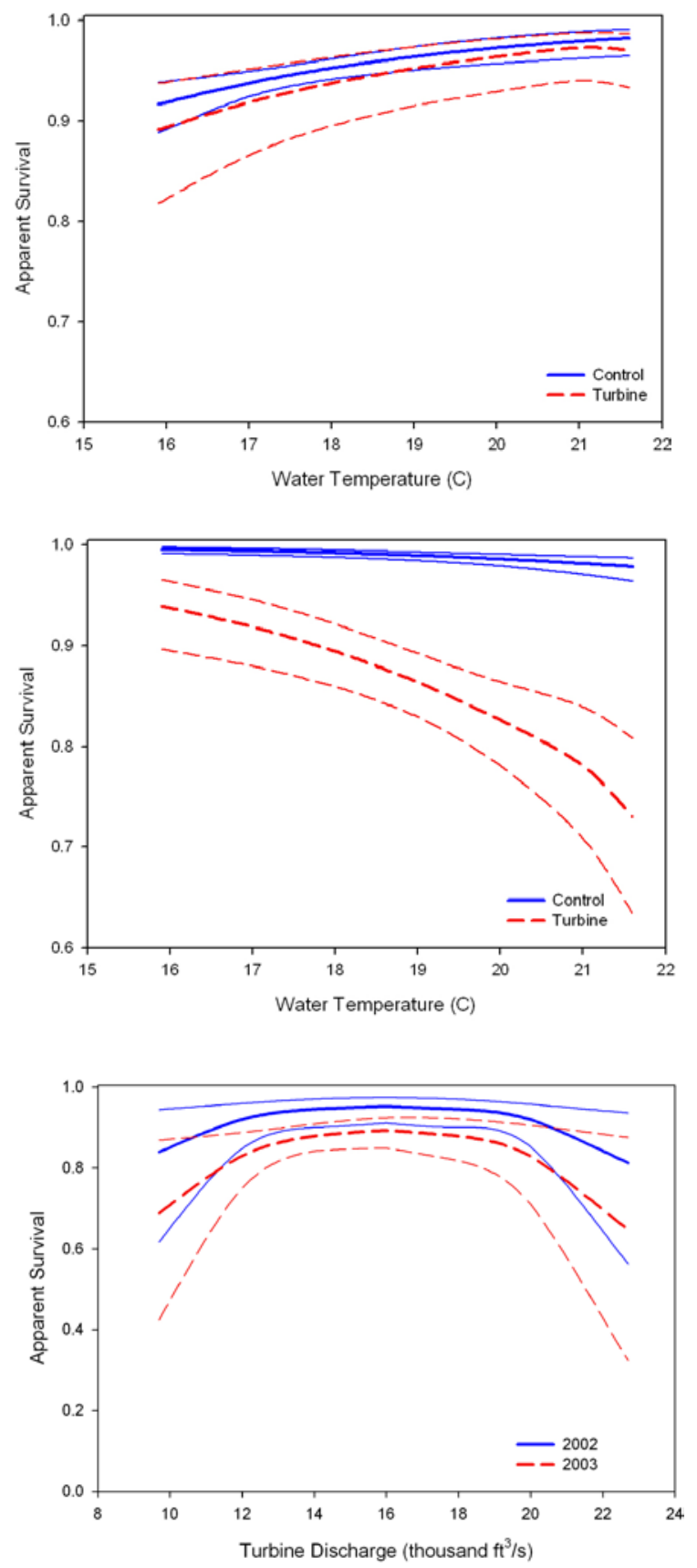

Figure 8. Graph showing the estimated effects of water temperature in 2002 (upper plate) and 2003 (middle plate) and turbine discharge (lower plate) on apparent survival of subyearling Chinook salmon from data used in studies at John Day Dam in 2002 and 2003. Predictions (thick lines) and 95 percent confidence intervals (thin lines) from model 18 in table 10 are plotted. 


\section{Results of Analyses from Studies at McNary Dam}

\section{Yearling Chinook Salmon}

\section{Environmental Conditions}

The environmental conditions occurring during fish passage differed among years available for analysis (2002-2009). The turbines were primarily operated within 1 percent of peak efficiency during fish passage (fig. 9). Covariate values at the time of fish passage are summarized in appendix $\mathrm{G}$ and daily averages are plotted in fig. 10. Overall turbine unit discharge ranged from 7.80 to 17.27 thousand $\mathrm{ft}^{3} / \mathrm{s}$ with a median of 11.90 thousand $\mathrm{ft}^{3} / \mathrm{s}$. The maximum turbine unit discharges were higher in 2002-2005 (16.30-17.27 thousand $\left.\mathrm{ft}^{3} / \mathrm{s}\right)$ than in 2006-2009 (12.42-13.11 thousand $\left.\mathrm{ft}^{3} / \mathrm{s}\right)$. The median head was $72.13 \mathrm{ft}$ (range 67.47 to $75.91 \mathrm{ft}$ ) and was slightly lower in 2006 (median $69.92 \mathrm{ft}$ ) than in the other years (medians ranging from 71.63 to $73.12 \mathrm{ft}$ ). The total project discharge, which was applied only to fish in the control group, ranged from 90.30 to 421.09 thousand $\mathrm{ft}^{3} / \mathrm{s}$ and had a median of 255.60 thousand $\mathrm{ft}^{3} / \mathrm{s}$. Percentage of spill varied among years and photoperiod according to annual study designs and environmental conditions (see table 1). Spill percentage spill ranged from 0.00 to 78.84 over the years of studies. The median tag burden was 4.35 percent (range 0.86 to 9.78 percent) and was similar in all years except 2003. In 2003, the tag burden was higher than in the other years, with a median of 7.06 percent and range of 3.47 to 9.78 percent. In 2003, a larger size transmitter was used to reduce regurgitation after gastric implantation. The median water temperature ranged from $10.72{ }^{\circ} \mathrm{C}$ in 2009 to $12.83^{\circ} \mathrm{C}$ in 2004 . Water temperature ranged from 8.11 to $15.78{ }^{\circ} \mathrm{C}$ among years with a median of $12.33^{\circ} \mathrm{C}$.

The data included fish passing through all turbine units (fig. 11). The distribution of the unit of passage was similar among years and overall was slightly greater in lowernumbered units (closer to the Oregon shore). This distribution generally reflects the percentage of time individual turbines were operating (fig. 11). Sample sizes for the turbine group were smaller in $2002(N=33)$ and $2003(N=95)$ than in the other years $(N=$ 162-287).

\section{Survival}

Two separate analyses were completed using data from McNary Dam due to the inconsistent resolution of the turbine unit of passage among years. An analysis of a data set restricted to 2002, 2003, 2004, 2005 and 2009, years with unit-specific passage assignments, was conducted first followed by analyses based on the complete data set from 2002-2009. 


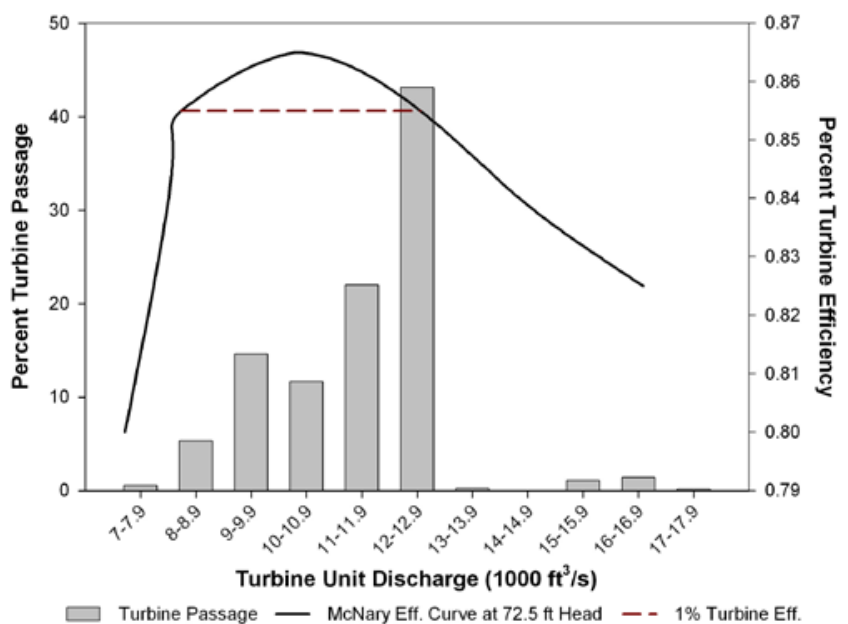

Figure 9. Graph showing turbine unit discharges during yearling Chinook salmon passage (bars) and turbine efficiency (solid line) from data used in studies at McNary Dam in 2002-2005 and 2009. The discharges bounded by the dashed line are within 1 percent peak turbine efficiency at a head of 72.5 feet.

The restricted analyses of survival at McNary Dam were based on 770 fish in the turbine group and 3,286 fish in the control group. Sample sizes varied among groups of treatment, year, and photoperiod and ranged from 114 to 1,219 per group for control fish and 12 to 189 per group for turbine fish (appendix H). There were no control fish in the studies during 2002 or 2003.

Correlation analyses indicated several variables were moderately related. Pearson correlation coefficients for fish weight and tag burden and total discharge and head were about $|0.80|$ indicating that the separate influence of these variables might not be reliably determined if used together (appendix I). Analyses of multicollinearity indicated no dependencies among the variables would result from these correlations. The correlations between head and total discharge would not be problematic in the analysis, because head was only applied to the turbine group and total discharge was only applied to the control group. As in analyses of data from John Day Dam, tag burden and fish weight were not used in models together. Rather, tag burden was used as a covariate and, if supported as a factor affecting survival, it was replaced with fish weight during post-hoc analyses to determine which was more supported as the causal factor.

A model of recapture probabilities based on a multiplicative effect of group and reach was best supported by the data and used for all survival models for the reduced data set. The AICc of this model was 67 units less than the next best-supported model (model 1 compared to model 2, appendix J) and received greater than 99.9 percent of the model weight. Thus, there was little evidence to support the other models of recapture probability evaluated. 

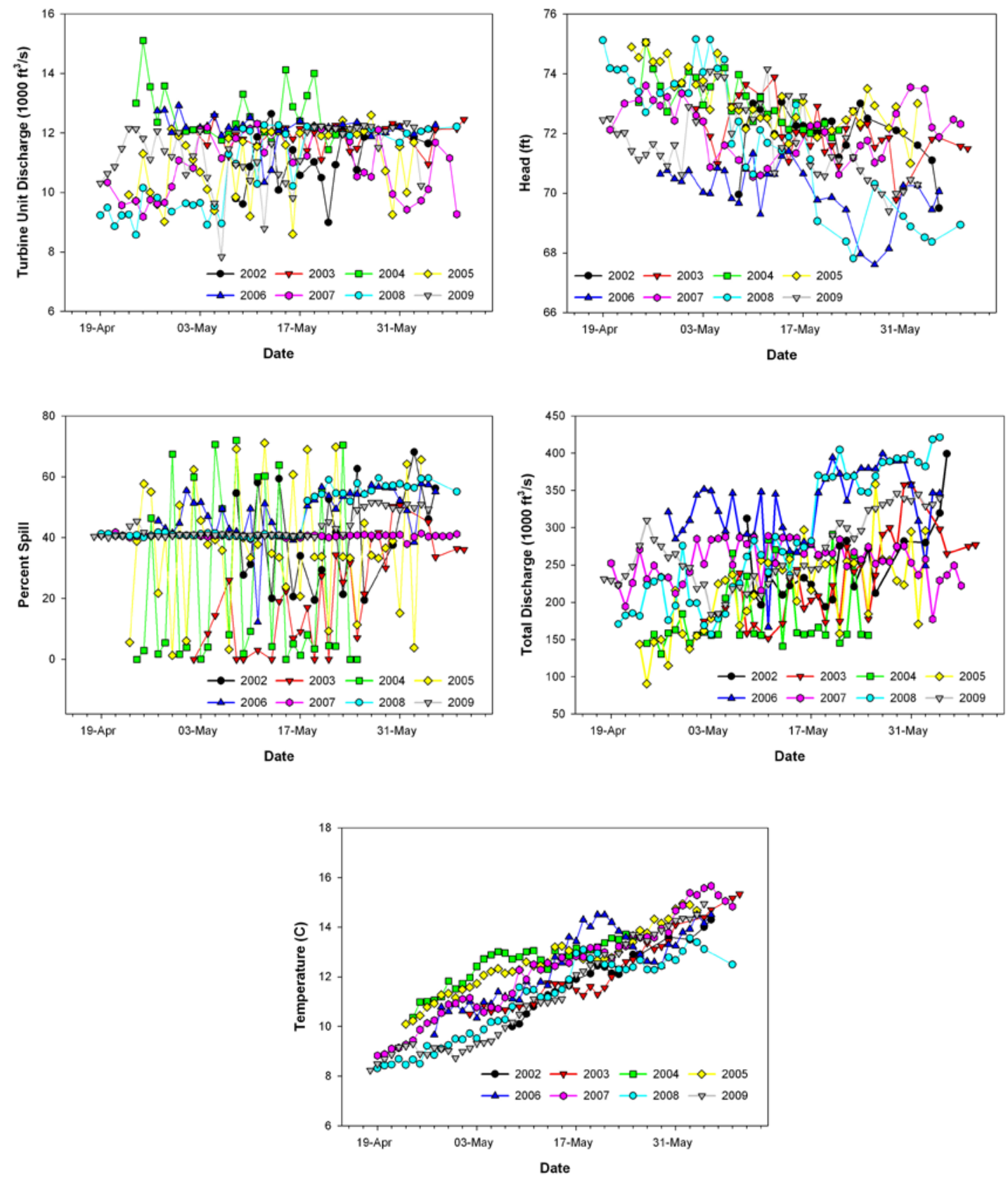

Figure 10. Graph showing daily-averaged covariate values for yearling Chinook salmon from data used in studies at McNary Dam in 2002-2009. 


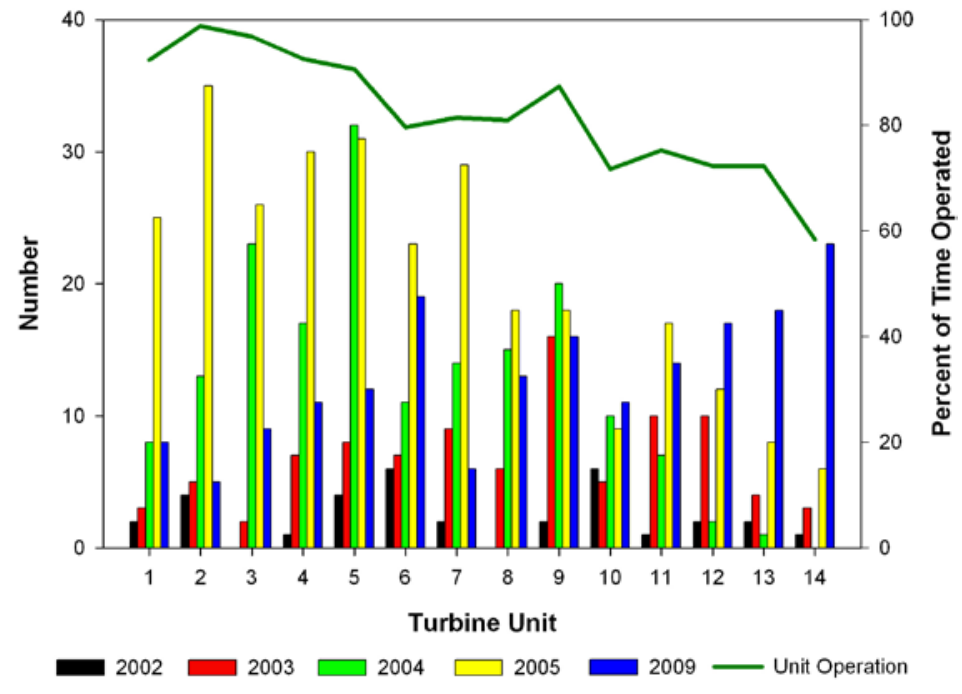

Figure 11. Graph showing number of yearling Chinook salmon passing through each turbine by year (bars) and overall percentage of time each turbine was operating (line) from data used in studies at McNary Dam in 2002-2005 and 2009. Unit-specific passage assignments were not made as part of the studies in 2002-2005 and 2009.

Effects on survival of five of the covariates examined were supported by the data and models from the reduced data set (appendixes $\mathrm{K}$ and $\mathrm{L}$ ). These included tag burden, head, percentage spill, water temperature, and total discharge. The linear model of head received only weak support with an AICc value 0.7 less than the model without head (model 13 compared to 14a), whereas the quadratic model had an AICc 0.3 greater than the model with no head effect and was not supported (model 14b compared to 14a). Both linear and quadratic models of turbine unit discharge had AICc values about 3 units greater than the model without turbine unit discharge and therefore were not supported (model 14b and $15 \mathrm{~b}$ compared to 15 ). The model containing water temperature, percentage spill, and total project discharge (model 9) had AICc values 2.8 to 12 units less than the alternative models without these covariates (models 10,11, and 12) indicating that they were moderately to strongly supported. Tag burden also received moderate support relative to the model without tag burden (model 16 compared to model 17). Because there was no evidence of an effect of turbine unit discharge, further analyses were conducted based on all the years of data (2002-2009).

The analyses of factors affecting survival of yearling Chinook salmon at McNary Dam using all the data were based on 1,419 fish in the turbine group and 6,737 fish in the control group (appendix M). Numbers of fish in the turbine and control groups were similar among years except in 2002 and 2003. In these years, there were no control groups and there were fewer fish in the turbine groups $(N=33$ in 2002 and $N=95$ in 2003) than in other years $(N=163-287)$.

Correlation analyses indicated that several variables in the full data set were related. As in the analysis of the smaller data set, Pearson correlation coefficients for fish weight and tag burden and total discharge and head were greater than or equal to $|0.79|$ indicating that the separate influence of these variables might not be separable when used together (tables 12 and 13). Analyses of multicollinearity indicated that only minor dependencies among the variables would result from these correlations and variance 
inflation factors were less than 5. As in the previous analysis, the correlation between head and total discharge would not be problematic in the analysis, because head was applied only to the turbine group and total discharge was applied only to the control group. Tag burden and fish weight also were treated as in the previous analysis. The unit-specific turbine of passage variable (turbloc) was replaced by a north or south passage location (unitloc) in the analyses of all years, because it was the only resolution common to all years.

A multiplicative recapture probability model of group and reach was supported by the data and used in all comparisons among survival models. This model received most of the AICc weight. The AICc value was 23 units less than the next best-supported model, indicating that it was the only model supported relative to the others evaluated (appendix N). Visual examination of the capture histories (appendix M) indicated that all fish in the sample from the turbine night group in 2009 were detected, so the capture probability was fixed to 1.0 for the first downriver reach. Similarly, the $\lambda$ for the turbine night group in 2003 in the second downriver reach was also fixed to 1.0. Capture histories also indicated that no mortality occurred in the sample from the turbine night group in 2002, so it was fixed to 1.0 for analysis. Recapture probabilities at the first downriver site ranged from 0.309 (SE 0.0.062) to 1.0 (manually fixed for analysis) and averaged 0.717 . The $\lambda$ parameter ranged from 0.461 (SE 0.050 ) to 1.0 (manually fixed for analysis), and averaged 0.849 .

Few of the individual covariates examined were supported as determinants of survival for the turbine group. Only tag burden, water temperature, total discharge, and head were supported by the data and models (table 14). The total discharge covariate, which was applied only to control fish, had a slightly positive effect on survival, and was included in models to account for environmental conditions apart from those related to powerhouse operation.

The operational covariates contributed little to the fit of the survival models examined with the exception of head. The model with a linear effect of head had an AICc value 1.4 units greater than the model without head and was not supported (model 13 compared to 14a). The quadratic model of head received moderate support compared to the model with no head effect as evidenced by an AICc that was 3.6 units lower (model 14a compared to 14b). That model simulates an intermediate maximum survival at a head of $71.2 \mathrm{ft}$, with a 95 percent confidence interval of 70.7-71.8 ft (fig. 12, table 15). Models with a linear or quadratic effect of turbine unit discharge had AICc values 1.8 and 2.1 greater than the model without turbine unit discharge and were not supported by the data (models 14b and 15b compared to model 15a). Similarly, models with percentage spill and a percentage spill by treatment interaction were not supported compared to the model without percentage spill (models 8 and 10 compared to model 12). The interaction effect of water temperature and year was strongly supported (model 1) with an AICc value about 8 units less than the model without this interaction (model 2). The effect of tag burden was also strongly supported with an AICc value nearly 11 units less than the alternative model without it (model 17 compared to model 16). Following the systematic evaluation of the individual and group covariates the best supported model contained only treatment, photoperiod, year, their interactions, and the individual covariates of tag burden, water temperature, total discharge, and a quadratic effect of head (model 16 in table 14). The post-hoc evaluation using fish weight in place of tag burden in the best-supported model indicated that weight was the better supported of the two correlated variables with an AICc value 3.4 units less than the model with tag burden (model 18 vs. model 16). 
Table 12. Table of correlation indices of data from yearling Chinook salmon from the turbine group from data used in studies at McNary Dam in 2002-2009.

[Pearson correlation coefficients are listed above the probabilities of obtaining a greater value under the hypothesis that $\mathrm{Rho}=0$. Sample size is 1,$419 ;<$, less than; see table 2 for variable name definitions]

\begin{tabular}{|c|c|c|c|c|c|c|c|c|c|}
\hline & TOTQ & PER_SPI & HEAD & TURQ & UNITLOC & РНОTO & TEMP & WEIGHT & $\begin{array}{c}\text { TAG } \\
\text { BURDEN }\end{array}$ \\
\hline \multirow[t]{2}{*}{ TOTQ } & 1.0000 & 0.6082 & -0.8693 & 0.2371 & -0.1919 & 0.1939 & 0.3038 & -0.0892 & 0.1022 \\
\hline & & $<0.0001$ & $<0.0001$ & $<0.0001$ & $<0.0001$ & $<0.0001$ & $<0.0001$ & 0.0008 & 0.0001 \\
\hline \multirow[t]{2}{*}{ PER_SPI } & & 1.0000 & -0.3156 & -0.2626 & -0.1579 & 0.4278 & -0.0121 & 0.0425 & -0.1181 \\
\hline & & & $<0.0001$ & $<0.0001$ & $<0.0001$ & $<0.0001$ & 0.6502 & 0.1098 & $<0.0001$ \\
\hline \multirow[t]{2}{*}{ HEAD } & & & 1.0000 & -0.3915 & 0.1523 & -0.0870 & -0.3601 & 0.0754 & -0.1496 \\
\hline & & & & $<0.0001$ & $<0.0001$ & 0.0010 & $<0.0001$ & 0.0045 & $<0.0001$ \\
\hline \multirow[t]{2}{*}{ TURQ } & & & & 1.0000 & 0.1253 & -0.0816 & 0.3595 & -0.0778 & 0.1902 \\
\hline & & & & & $<0.0001$ & 0.0021 & $<0.0001$ & 0.0034 & $<0.0001$ \\
\hline \multirow[t]{2}{*}{ UNITLOC } & & & & & 1.0000 & 0.0167 & 0.1332 & -0.0061 & -0.0460 \\
\hline & & & & & & 0.5293 & $<0.0001$ & 0.8188 & 0.0832 \\
\hline \multirow[t]{2}{*}{ РНОТО } & & & & & & 1.0000 & -0.0227 & -0.0080 & -0.0425 \\
\hline & & & & & & & 0.3936 & 0.7625 & 0.1097 \\
\hline \multirow[t]{2}{*}{ TEMP } & & & & & & & 1.0000 & -0.2044 & 0.1692 \\
\hline & & & & & & & & $<0.0001$ & $<0.0001$ \\
\hline \multirow[t]{2}{*}{ WEIGHT } & & & & & & & & 1.0000 & -0.7917 \\
\hline & & & & & & & & & $<0.0001$ \\
\hline
\end{tabular}

Low and high values of head and high values of water temperature and tag burden had negative effects on survival in most years. Values of head that were in the mid-range near $71 \mathrm{ft}$ had higher rates of survival than those that were in the lower or higher part of the range of observed values (fig. 12). The model slopes generally indicate a greater temperature effect on turbine fish during the day than on turbine fish at night or control groups during day or night (table 15). A negative effect of water temperature on survival was supported for all years except for 2006 in which the effect was positive (fig. 13). Post-hoc analyses indicated this anomaly was caused by a treatment, year, temperature interaction, which did not affect the interpretation of the important factors. Survival estimates of the control groups generally were higher than for the turbine groups, as expected. Tag burden had a negative effect on survival in all years, but it was more pronounced for the turbine group than the control group (fig. 14). A positive effect of total discharge was also supported. 
Table 13. Table of correlation indices of data from yearling Chinook salmon from the control group from data used in studies at McNary Dam in 2002-2009.

[Pearson correlation coefficients are listed above the probabilities of obtaining a greater value under the hypothesis that Rho $=0$. Sample size is 6,$737 ;<$, less than; see table 2 for variable name definitions]

\begin{tabular}{|c|c|c|c|c|c|c|}
\hline & TOTQ & PER_SPI & РНОТО & TEMP & WEIGHT & $\begin{array}{c}\text { TAG } \\
\text { BURDEN }\end{array}$ \\
\hline TOTQ & 1.0000 & $\begin{array}{r}0.5873 \\
<0.0001\end{array}$ & $\begin{array}{l}-0.1071 \\
<0.0001\end{array}$ & $\begin{array}{r}0.2913 \\
<0.0001\end{array}$ & $\begin{array}{l}-0.1141 \\
<0.0001\end{array}$ & $\begin{array}{r}0.1996 \\
<0.0001\end{array}$ \\
\hline PER_SPI & & 1.0000 & $\begin{array}{r}0.2342 \\
<0.0001\end{array}$ & $\begin{array}{r}0.0597 \\
<0.0001\end{array}$ & $\begin{array}{r}-0.0321 \\
0.0085\end{array}$ & $\begin{array}{l}0.0219 \\
0.0721\end{array}$ \\
\hline РНОТО & & & 1.0000 & $\begin{array}{l}-0.1809 \\
<0.0001\end{array}$ & $\begin{array}{r}0.0858 \\
<0.0001\end{array}$ & $\begin{array}{l}-0.1292 \\
<0.0001\end{array}$ \\
\hline TEMP & & & & 1.0000 & $\begin{array}{l}-0.1742 \\
<0.0001\end{array}$ & $\begin{array}{r}0.1617 \\
<0.0001\end{array}$ \\
\hline WEIGHT & & & & & 1.0000 & $\begin{array}{l}-0.8487 \\
<0.0001\end{array}$ \\
\hline
\end{tabular}




\section{Key Findings in Data from Yearling Chinook Salmon at McNary Dam}

- Initial analyses were based on a subset of the data because turbine unitspecific passage location was not available in all years. Unit-specific discharge was not supported as a factor on survival in these data (from 2002 to 2008 and 2009), so inferences were based on the full 2002-2009 data set and a "north-south" assignment for unit passage location.

- The full data set included 1,419 fish in the turbine group and 6,737 fish in the control group.

- Most data were collected at turbine discharges within 1 percent of peak unit efficiency.

- A positive effect of total discharge on survival was moderately supported (this covariate was applied only to the control group).

- Head was moderately supported as a factor affecting turbine passage survival. A curvilinear fit to the data indicated maximum turbine passage survival at a head of $71.2 \mathrm{ft}$ with lower survival at greater or lesser values.

- Water temperature was supported as a factor affecting turbine passage survival. A difference in the effect of water temperature among years was strongly supported: the effect of water temperature was positive in 2006 and negative in all other years.

- A negative effect of tag burden was strongly supported. There was moderate support for the alternative hypothesis that this was due to fish weight rather than tag burden. 
Table 14. Model-selection results from radio- and acoustic-tagged yearling Chinook salmon from data used in studies at McNary Dam in 20022009.

[Presence of a factor in a model is indicated by an ' $\mathrm{x}$ ' in the column for that factor. Model 1 was a global model including all group covariates and their interactions $(\mathrm{g})$ as well as all individual covariates and interactions listed. All models shared a common $\mathrm{g}$ *reach model of recapture probability. $\mathrm{K}$ indicates the number of parameters. An asterisk after the model number indicates the best-supported model of the suite]

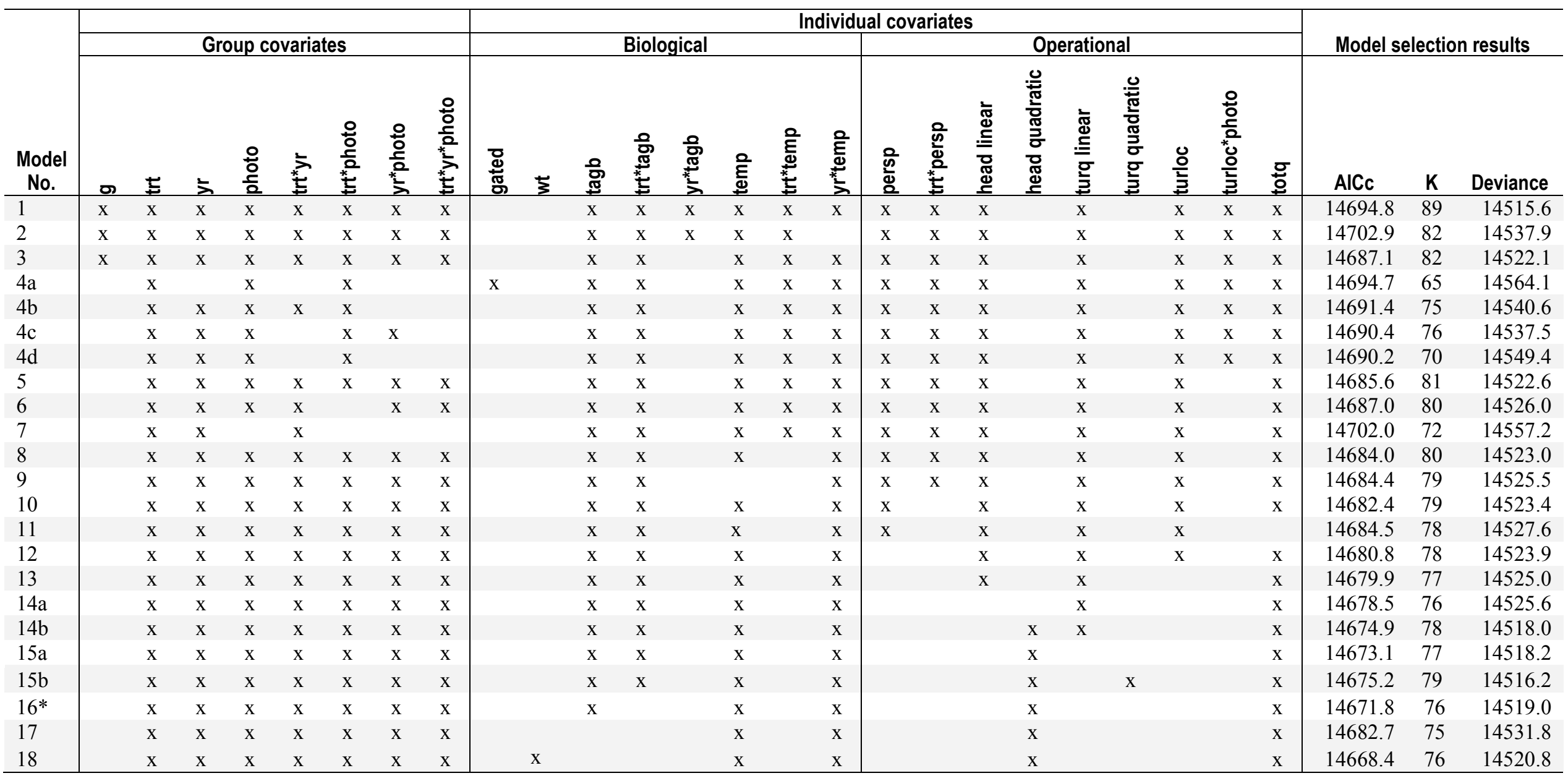




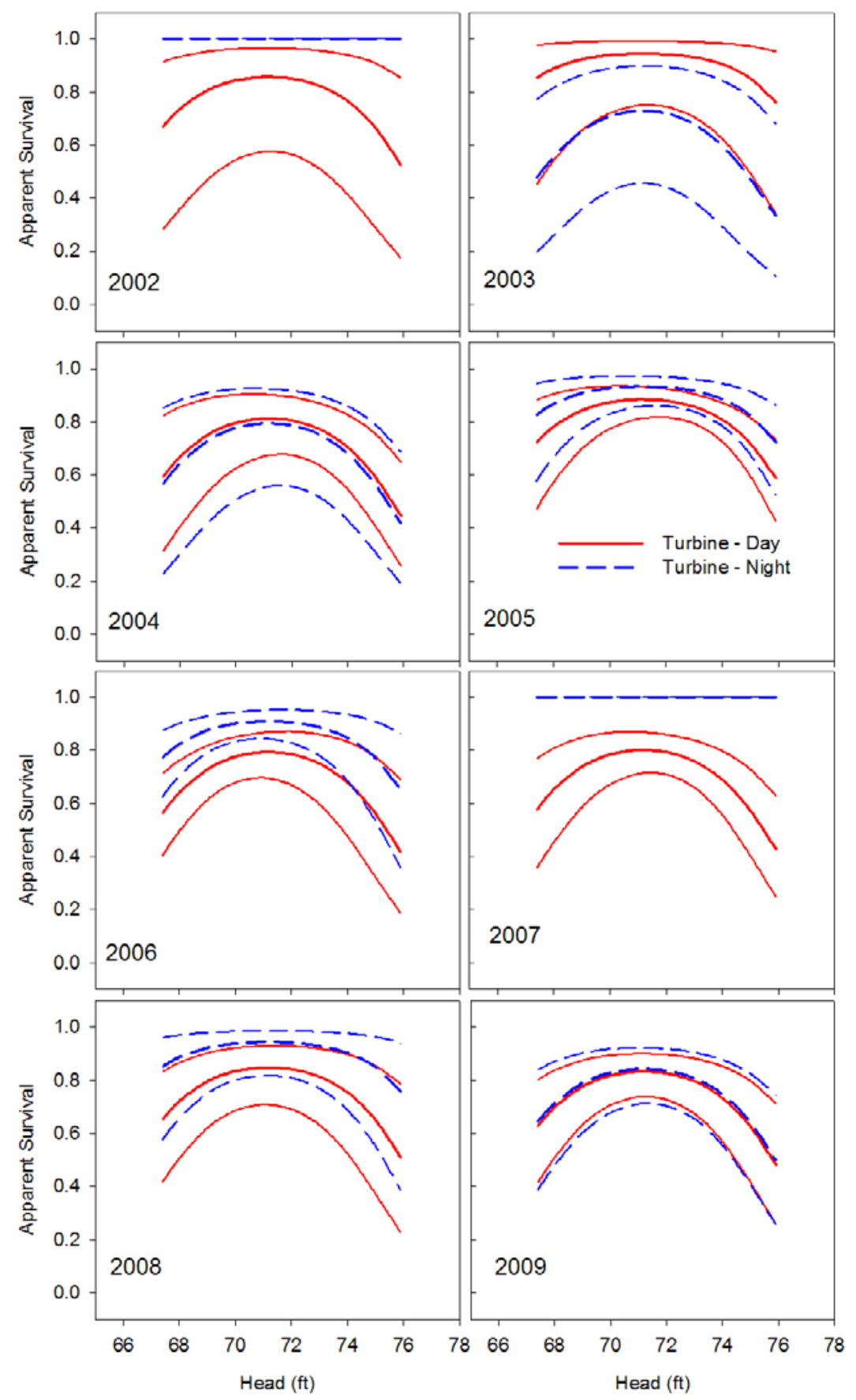

Figure 12. Graph showing estimated effects of head on apparent survival of yearling Chinook salmon at McNary Dam in 2002-2009. Predictions (thick lines) and 95 percent confidence intervals (thin lines) from model 16 in table 14 are plotted. 
Table 15. data used in studies at McNary Dam in 2002-2009.

[The data are from model 16 in table 14]

\begin{tabular}{|c|c|c|c|c|}
\hline \multirow[b]{2}{*}{ Parameter } & \multirow[b]{2}{*}{ Beta } & \multirow{2}{*}{$\begin{array}{c}\text { Standard } \\
\text { error }\end{array}$} & \multicolumn{2}{|c|}{95 percent confidence } \\
\hline & & & Lower & Upper \\
\hline intercept & 6.7960 & 2.7932 & 1.3214 & 12.2705 \\
\hline treatment & -384.8641 & 2.1281 & -389.0352 & -380.6930 \\
\hline photo & 1.0985 & 0.9047 & -0.6747 & 2.8717 \\
\hline 2005 & 1.4746 & 3.0765 & -4.5553 & 7.5045 \\
\hline 2006 & -7.9079 & 3.0029 & -13.7936 & -2.0223 \\
\hline 2007 & -0.9634 & 2.9527 & -6.7508 & 4.8240 \\
\hline 2008 & -0.4017 & 3.3019 & -6.8734 & 6.0700 \\
\hline 2009 & -2.4378 & 2.8305 & -7.9857 & 3.1100 \\
\hline 2002 & -1.9472 & 7.6035 & -16.8501 & 12.9558 \\
\hline 2003 & 2.5164 & 5.1175 & -7.5139 & 12.5466 \\
\hline treatment*photo & -1.2107 & 0.6779 & -2.5395 & 0.1181 \\
\hline treatment*2005 & -0.5280 & 0.5670 & -1.6392 & 0.5833 \\
\hline treatment $* 2006$ & -0.5468 & 0.6364 & -1.7942 & 0.7006 \\
\hline treatment*2007 & -0.9346 & 0.6615 & -2.2311 & 0.3619 \\
\hline treatment $* 2008$ & -0.7543 & 0.7552 & -2.2345 & 0.7259 \\
\hline treatment*2009 & 0.6700 & 0.5831 & -0.4730 & 1.8129 \\
\hline photo*2005 & -1.3721 & 1.0370 & -3.4046 & 0.6604 \\
\hline photo*2006 & 1.0762 & 0.7204 & -0.3358 & 2.4881 \\
\hline photo*2007 & 484.2001 & 0.0000 & 484.2001 & 484.2001 \\
\hline photo*2008 & 1.2204 & 0.9388 & -0.6197 & 3.0605 \\
\hline photo*2009 & 0.1860 & 0.7605 & -1.3046 & 1.6765 \\
\hline photo $* 2003$ & -1.7392 & 1.1979 & -4.0871 & 0.6088 \\
\hline treatment*photo*2005 & 2.0918 & 0.9478 & 0.2341 & 3.9494 \\
\hline tag burden & -0.2462 & 0.0704 & -0.3841 & -0.1082 \\
\hline head & 10.8140 & 0.0000 & 10.8140 & 10.8140 \\
\hline head $^{\wedge} 2$ & -0.0759 & 0.0003 & -0.0766 & -0.0753 \\
\hline totq & 0.0058 & 0.0020 & 0.0018 & 0.0098 \\
\hline temp & -0.3519 & 0.2134 & -0.7701 & 0.0664 \\
\hline temp*2005 & -0.0304 & 0.2381 & -0.4970 & 0.4362 \\
\hline temp*2006 & 0.6758 & 0.2373 & 0.2107 & 1.1410 \\
\hline temp*2007 & 0.1479 & 0.2287 & -0.3003 & 0.5961 \\
\hline temp*2008 & 0.1143 & 0.2659 & -0.4069 & 0.6354 \\
\hline temp*2009 & 0.1547 & 0.2232 & -0.2827 & 0.5921 \\
\hline temp*2002 & 0.1837 & 0.6169 & -1.0254 & 1.3929 \\
\hline temp*2003 & -0.0925 & 0.4110 & -0.8981 & 0.7130 \\
\hline
\end{tabular}



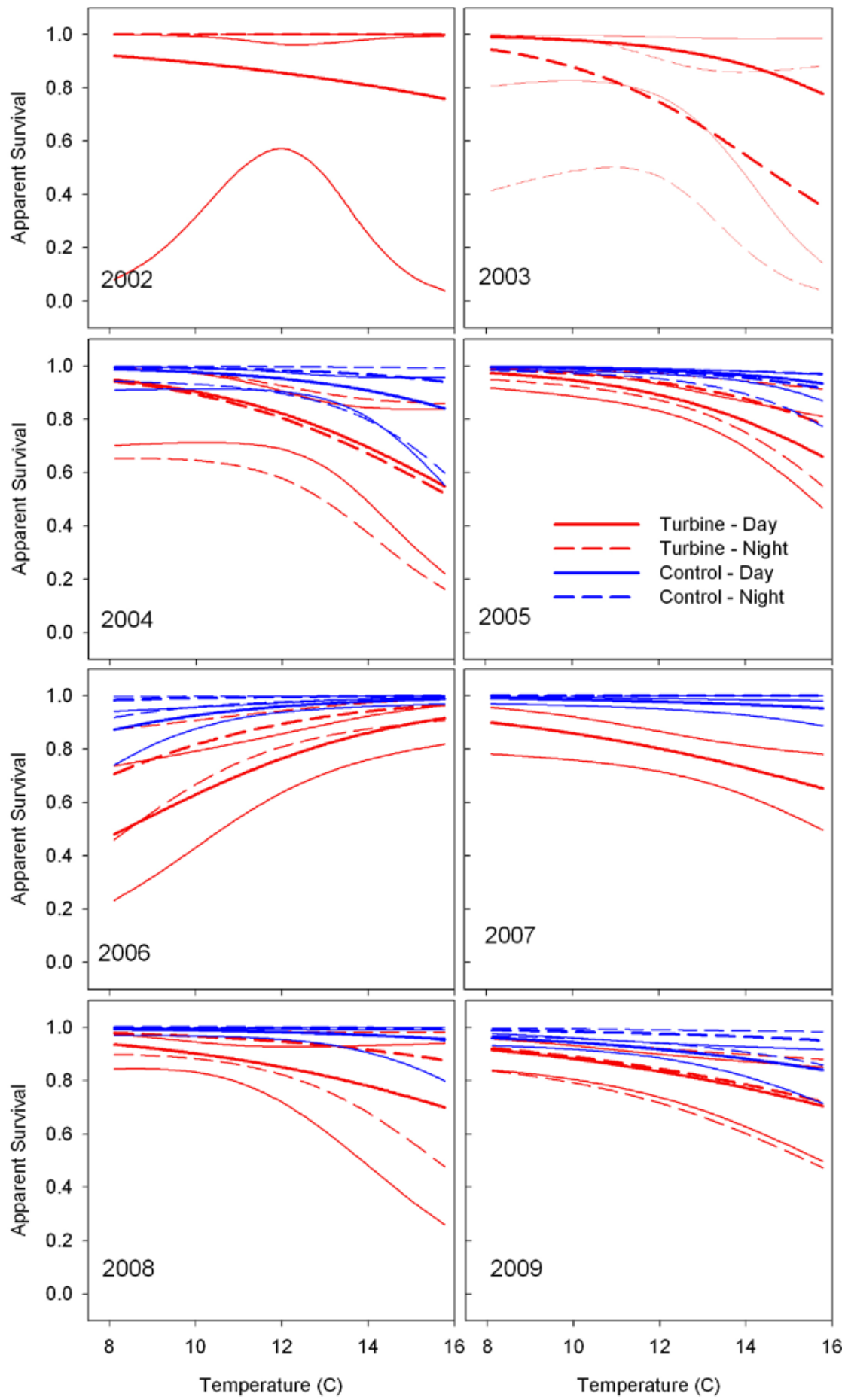

Figure 13. Graph showing estimated effects of water temperature on apparent survival of yearling Chinook salmon from data used in studies at McNary Dam in 2002-2009. Predictions (thick lines) and 95 percent confidence intervals (thin lines) from model 16 in table 14 are plotted. 


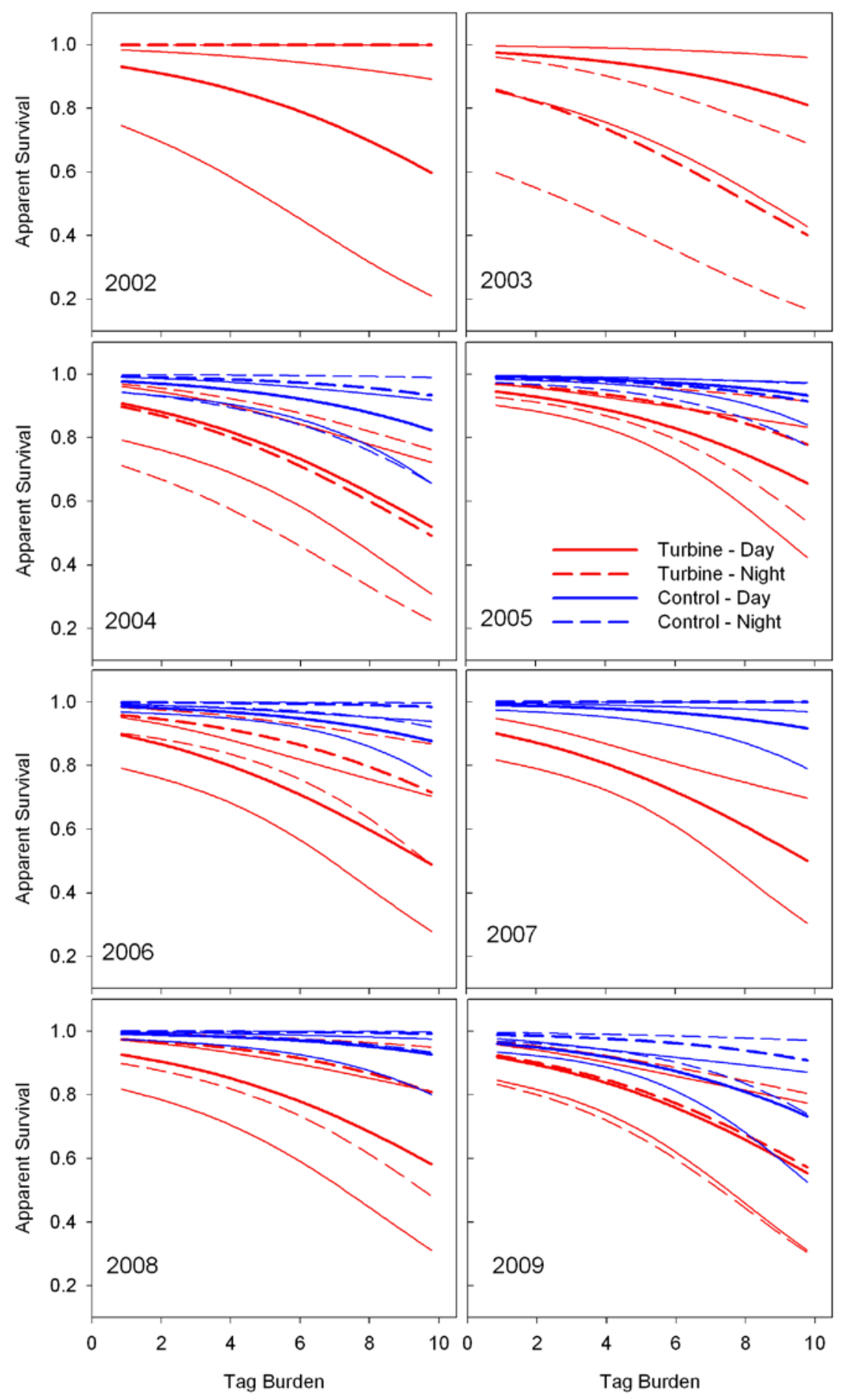

Figure 14. Graph showing estimated effects of tag burden on apparent survival of yearling Chinook salmon from data used in studies at McNary Dam in 2002-2009. Predictions (thick lines) and 95 percent confidence intervals (thin lines) from model 16 in table 14 are plotted. 


\section{Juvenile Steelhead}

\section{Environmental Conditions}

The environmental conditions during passage of juvenile steelhead differed among the years analyzed (2004-2009). The turbines were operated primarily within 1 percent of peak efficiency during fish passage (fig. 15). Covariate values at the time of fish passage are summarized in appendix P and daily averages are plotted in fig. 16. Overall turbine unit discharge ranged from 7.90 to 16.60 thousand $\mathrm{ft}^{3} / \mathrm{s}$ with a median of 11.90 thousand $\mathrm{ft}^{3} / \mathrm{s}$. The maximum turbine unit discharges were higher in 2004 and 2005 $\left(16.30-16.60\right.$ thousand $\left.\mathrm{ft}^{3} / \mathrm{s}\right)$ than in 2006-2009 $\left(12.28-12.94\right.$ thousand $\left.\mathrm{ft}^{3} / \mathrm{s}\right)$. The median head was $71.98 \mathrm{ft}$ (range 67.36 to $75.64 \mathrm{ft}$ ) and it was lower in $2006(70.11 \mathrm{ft}$ ) than during the other years (range in medians 71.32 to $73.76 \mathrm{ft}$ ). The total project discharge, which was applied as a covariate only to the control group, ranged from 90.90 to 418.52 thousand $\mathrm{ft}^{3} / \mathrm{s}$ and had a median of 235.92 thousand $\mathrm{ft}^{3} / \mathrm{s}$. Spill percentage varied among years and photoperiod according to annual study designs and environmental conditions (see table 1). Spill percentage ranged from 0.00 to 78.49 for the years analyzed. The median tag burden was 1.89 percent (range 0.60 to 6.41 percent) and was similar for all years (range of medians 1.49 to 2.12 percent). The median water temperature ranged from $10.72{ }^{\circ} \mathrm{C}$ in 2008 and 2009 to $13.03{ }^{\circ} \mathrm{C}$ in 2007 . Daily water temperature ranged from 8.11 to $15.67^{\circ} \mathrm{C}$ among years with a median of $11.72{ }^{\circ} \mathrm{C}$.

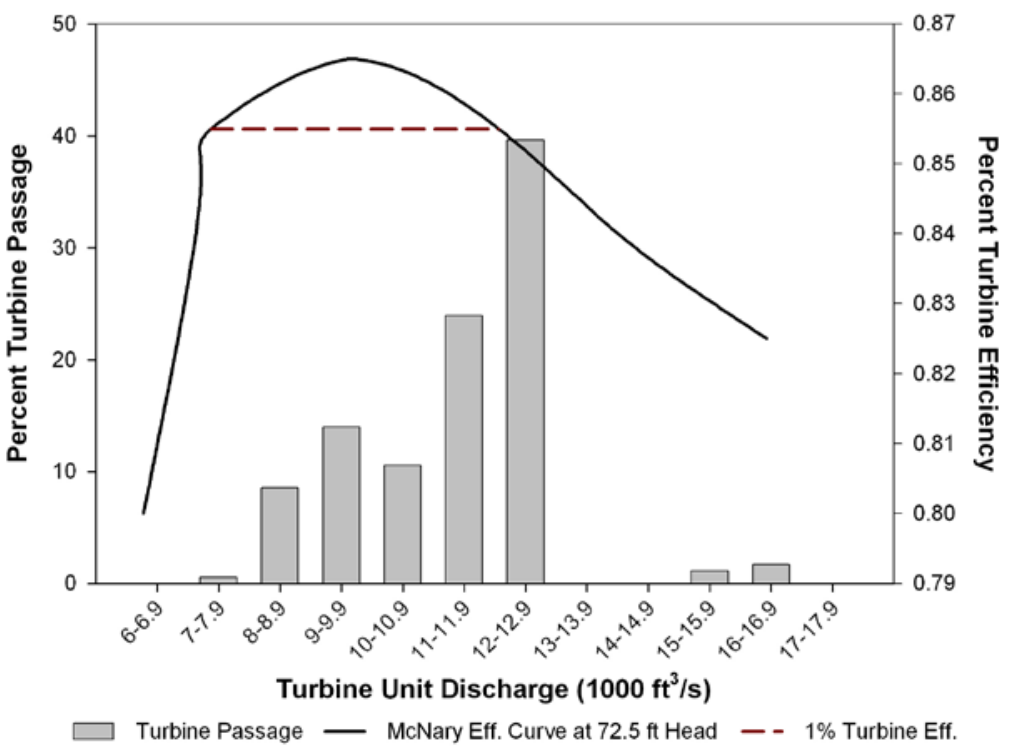

Figure 15. Graph showing turbine unit discharges during juvenile steelhead passage (bars) and turbine efficiency (solid line) from data used in studies at McNary Dam in 2004-2009. The discharges bounded by the dashed line are within 1 percent of the peak turbine efficiency at a head of 72.5 feet. 

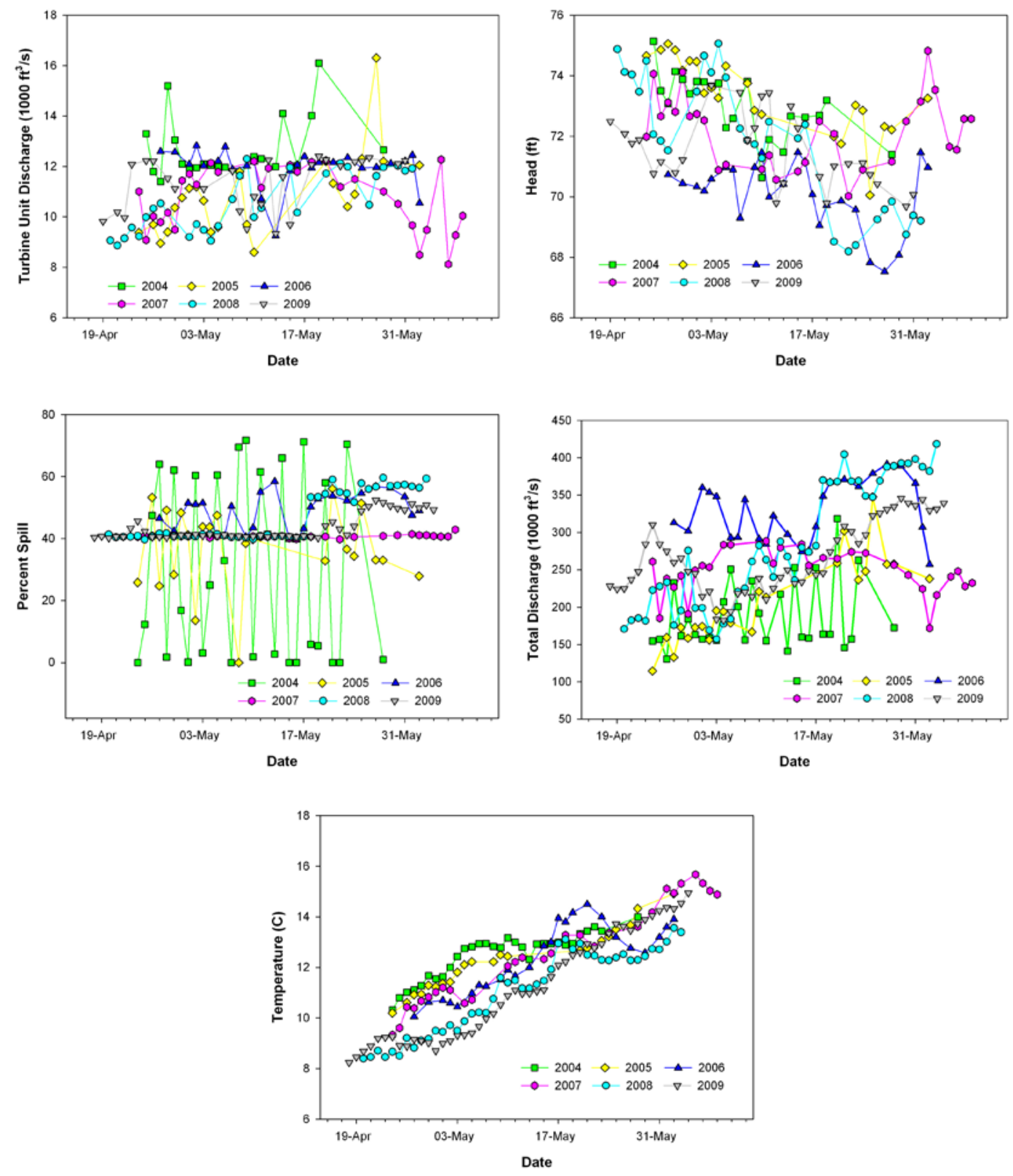

Figure 16. Graph showing daily-averaged covariate values for juvenile steelhead from data used in studies at McNary Dam in 2004-2009.

The passage data included fish passing through all turbine units (fig. 17). In 2004 and 2005, most fish passed through turbine units 1-7 (closer to the Oregon shore) where the turbines were operating a higher percentage of the time. In 2009, the median total discharge was higher than the other 2 years and passage tended to be more evenly distributed across the powerhouse. 


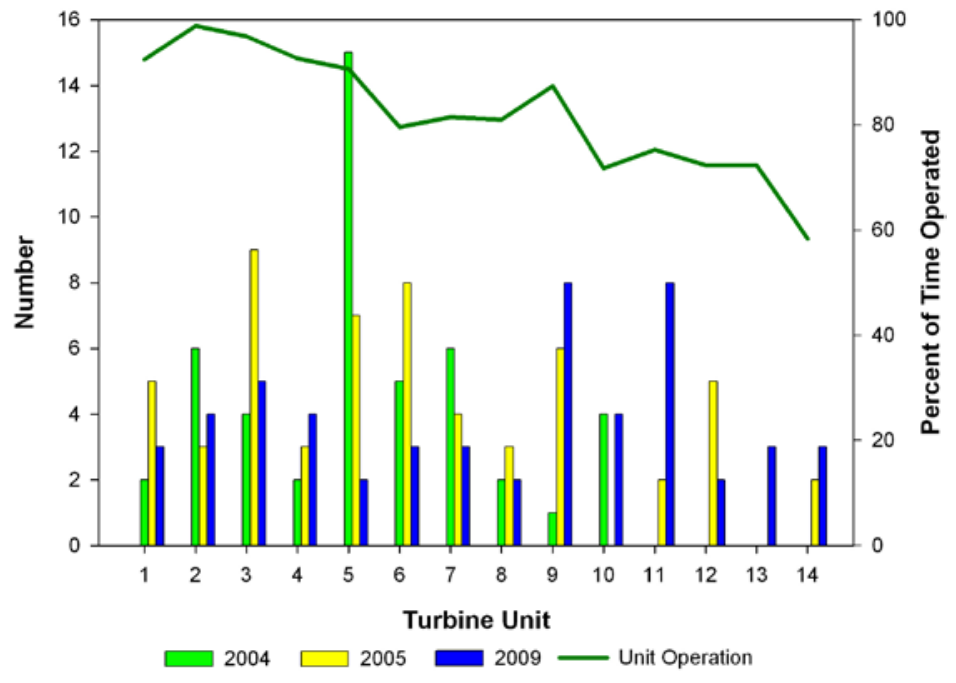

Figure 17. Graph showing number of juvenile steelhead passing through each turbine by year (bars) and overall percentage of time individual turbine units were operating (line) from data used in studies at McNary Dam in 2004, 2005, and 2009. Unit-specific passage assignments were not made as part of the studies in 2006-2008.

\section{Survival}

As in analyses of Chinook salmon at McNary Dam, two separate analyses of data from juvenile steelhead were conducted due to differences in turbine unit specificity when assigning turbine passage among years. First an analysis restricted to years having unit-specific passage locations (2004, 2005, and 2009) was performed, followed by an analysis of all years, 2004-2009.

The restricted analysis was based on 158 fish in the turbine group and 1,531 fish in the control group. Turbine and control groups contained similar numbers of fish among years, except 2005 when there were no control fish (appendix P). Pearson correlation coefficients ranged from $|0.75|$ to $|0.84|$ for the covariate pairs of fish weight and tag burden and total discharge and head (appendix Q). Analyses of multicollinearity indicated moderate dependencies associated with total discharge and head for the turbine group (variance inflation factor: total discharge $=9.2$, head $=7.5$ ), but no other serious dependencies were indicated for the turbine or control groups. As in previous analyses, we applied head only to the turbine group and total discharge to the control group and we used tag burden for all analyses, with post-hoc replacement with fish weight if a tag burden effect was supported by the data. 
In the restricted analysis, a multiplicative model of recapture probabilities by group and reach was supported by the data and used in all comparisons among survival models (appendix R). The AICc for this model was about 54 units lower than the next best model indicating a much better fit to the data than the other models of recapture probability. Of the individual covariates examined, tag burden was weakly supported and spill percentage was moderately supported by the data and models as determinants of survival for the turbine group. In addition to these variables, total discharge was weakly supported for the control group (appendixes $\mathrm{S}$ and $\mathrm{T}$ ). Models with linear and quadratic effects of head (models 13 and 14b) had AICc values 1.6 and 3.3 greater than the model without head (model 14a). Similarly, models with linear and quadratic effects of turbine unit discharge (models 14a and 15b) had AICc values 2.0 and 3.7 greater than the model with no turbine discharge effect (model 15a). These results indicate weak or no support for head or turbine unit discharge on turbine survival. Because an effect of turbine unit discharge on survival was not supported by these data, further analyses were based on the full 2004-2009 data set.

The analyses of factors affecting survival based on data from all years were based on 351 fish in the turbine group and 2,316 fish in the control group (appendix U). Numbers of fish in the turbine group ranged from 47 to 79 fish among years, whereas control fish numbers ranged from 746 to 785 for years in which control releases were made. No juvenile steelhead control releases were made during 2005-2007.

Correlation analyses indicated that the relation between two pairs of the individual covariates was moderately high in the data from all years. Pearson correlation coefficients for fish weight and tag burden were $|0.82|$ for turbine and control groups and the coefficient for head and total discharge for the turbine group was $|0.9262|$ (tables 16 and 17). The variance inflation factors for total discharge and head were 14.4 and 10.8 for the turbine group also indicating moderately high dependencies between the two covariates; total discharge and head therefore were used in the manner described previously. The location of the turbine unit of passage used in the restricted data set was replaced by a north or south passage location for all years, because that resolution was common to all years.

A multiplicative recapture probability model of group and reach was supported by the data for all years and was used in all comparisons among survival models. Examination of data in appendix $U$ indicated all fish from several control and turbine groups were detected at one or more of the downstream sites, so their recapture or $\lambda$ parameters were fixed to 1.0 in the analyses. The AICc for this model was 116 units smaller than the next best model indicating a better fit to the data than the other models of recapture probability (model 1 in appendix table $\mathrm{V}$ ). Recapture probabilities at the first downriver site ranged from 0.250 (SE 0.108 ) to 1.000 (fixed for analysis) and averaged 0.739 . The $\lambda$ parameters ranged from 0.774 (SE 0.079) to 1.000 (fixed for analysis) and averaged 0.908 . 
Table 16. Table of correlation indices of data from juvenile steelhead from the turbine group from data used in studies at McNary Dam in 2004-2009.

[Pearson correlation coefficients are listed above the probabilities of obtaining a greater value under the hypothesis that $\mathrm{Rho}=0$. Sample size is $351 ;<$, less than; see table 2 for variable name definitions]

\begin{tabular}{|c|c|c|c|c|c|c|c|c|}
\hline & PER_SPI & HEAD & TURQ & UNITLOC & РНОTO & TEMP & WEIGHT & $\begin{array}{c}\text { TAG } \\
\text { BURDEN }\end{array}$ \\
\hline \multirow[t]{2}{*}{ TOTQ } & 0.5179 & -0.9262 & 0.3740 & -0.2733 & -0.0678 & 0.3287 & -0.1260 & 0.1567 \\
\hline & $<0.0001$ & $<0.0001$ & $<0.0001$ & $<0.0001$ & 0.2051 & $<0.0001$ & 0.0182 & 0.0033 \\
\hline \multirow[t]{2}{*}{ PER_SPI } & 1.0000 & -0.2959 & -0.0231 & -0.1321 & 0.3337 & 0.0753 & -0.1340 & 0.0566 \\
\hline & & $<0.0001$ & 0.6664 & 0.6664 & $<0.0001$ & 0.1591 & 0.0120 & 0.2899 \\
\hline \multirow[t]{2}{*}{ HEAD } & & 1.0000 & -0.4112 & 0.2532 & 0.1455 & -0.3065 & 0.1053 & -0.1847 \\
\hline & & & $<0.0001$ & $<0.0001$ & 0.0063 & $<0.0001$ & 0.0487 & 0.0005 \\
\hline \multirow[t]{2}{*}{ TURQ } & & & 1.0000 & 0.0074 & -0.1057 & 0.2747 & -0.0328 & 0.2044 \\
\hline & & & & 0.8908 & 0.0478 & $<0.0001$ & 0.5407 & 0.0001 \\
\hline \multirow[t]{2}{*}{ UNITLOC } & & & & 1.0000 & 0.0961 & 0.0534 & 0.0333 & 0.0094 \\
\hline & & & & & 0.0721 & 0.3188 & 0.5341 & 0.8608 \\
\hline \multirow[t]{2}{*}{ РНОTO } & & & & & 1.0000 & -0.1413 & -0.0044 & -0.0871 \\
\hline & & & & & & 0.0080 & 0.9348 & 0.1033 \\
\hline \multirow[t]{2}{*}{ TEMP } & & & & & & 1.0000 & 0.0010 & 0.1346 \\
\hline & & & & & & & 0.9856 & 0.0116 \\
\hline \multirow[t]{2}{*}{ WEIGHT } & & & & & & & 1.0000 & -0.8252 \\
\hline & & & & & & & & $<0.0001$ \\
\hline
\end{tabular}

Head and spill percentage were the only individual covariates that were supported by the data and models for all years as having an effect on turbine passage survival (table 18). The final model after all group and individual covariates had been systematically evaluated included the effects of treatment, total discharge for the control group, photoperiod for the turbine group, unique spill percentage effects for the turbine and control groups, and a quadratic effect of head (model 18 in table 18). The model with a 
Table 17. Table of correlation indices of data from juvenile steelhead from the control group from data used in studies at McNary Dam in 2004-2009.

[Pearson correlation coefficients are listed above the probabilities of obtaining a greater value under the hypothesis that $\mathrm{Rho}=0$. Sample size is 2,$316 ;<$, less than; see table 2 for variable name definitions]

\begin{tabular}{|c|c|c|c|c|c|}
\hline & PER_SPI & РНОTO & TEMP & WEIGHT & $\begin{array}{c}\text { TAG } \\
\text { BURDEN }\end{array}$ \\
\hline \multirow[t]{2}{*}{ TOTQ } & 0.5872 & -0.0296 & 0.2583 & -0.1312 & -0.0228 \\
\hline & $<0.0001$ & 0.1539 & $<0.0001$ & $<0.0001$ & 0.2736 \\
\hline \multirow[t]{2}{*}{ PER_SPI } & 1.0000 & 0.2614 & -0.0659 & -0.0886 & -0.0601 \\
\hline & & $<0.0001$ & 0.0015 & $<0.0001$ & 0.0038 \\
\hline \multirow[t]{2}{*}{ Рното } & & 1.0000 & -0.1096 & 0.0426 & -0.0627 \\
\hline & & & $<0.0001$ & 0.0402 & 0.0025 \\
\hline \multirow[t]{2}{*}{ TEMP } & & & 1.0000 & 0.0427 & 0.2171 \\
\hline & & & & 0.0398 & $<0.0001$ \\
\hline \multirow[t]{2}{*}{ WEIGHT } & & & & 1.0000 & -0.8160 \\
\hline & & & & & $<0.0001$ \\
\hline
\end{tabular}

linear effect of head (model 13) was only weakly supported with an AICc 1.2 less than the model without head. The quadratic model of head (model 14b) received moderate support, with an AICc value 5.7 less than the model without head (model 14a). That this effect for the turbine group. Survival of the control group was higher than survival of the turbine group and survival of the turbine group was higher at night than during the day. An effect of photoperiod (day/night) on survival of the control group was not supported. 


\section{Key Findings in Data from Juvenile Steelhead at McNary Dam}

- Initial analyses were based on a subset of the data because turbine unitspecific passage location was not available in all years. Unit-specific discharge was not supported as a factor on survival in these data (from 2004, 2005, and 2009), so inferences were based on the full 2004-2009 data set and a "north-south" assignment for unit passage location.

- The full data set included 351 fish in the turbine group and 2,316 fish in the control group.

- Most data were collected at turbine discharges within 1 percent of peak unit efficiency.

- Head was moderately supported as a factor affecting turbine passage survival. A curvilinear fit to the data indicated minimum turbine passage survival at a head of $73.1 \mathrm{ft}$ with higher survival at greater or lesser values. This effect is in the opposite direction as the effect supported by data from yearling Chinook salmon at McNary Dam.

- Spill percentage was supported as a factor affecting survival. A negative effect of spill percentage was moderately supported as a factor affecting passage survival and a different effect of fish in turbine and controls groups was weakly supported. The final model described a smaller negative effect of spill percentage on control fish than on turbine fish.

- An effect of photoperiod was supported on survival of fish in the turbine group, but not those of the control group. The data and models indicated greater turbine passage survival at night than during the day.

- An effect of tag burden on survival was not supported from the full (20042009) data set, but a negative effect was weakly supported in the restricted data set (2004, 2005, and 2009). 
Table 18. Model-selection results from radio- and acoustic-tagged juvenile steelhead from data used in studies at McNary Dam in 2004-2009.

[Presence of a factor in a model is indicated by an ' $x$ ' in the column for that factor. Model 1 was a global model including all group covariates and their interactions ( $\mathrm{g}$ ) as well as all individual covariates and interactions listed. All models shared a common $\mathrm{g}$ *reach model of recapture probability. $\mathrm{K}$ indicates the number of parameters. An asterisk after the model number indicates the best-supported model of the suite]

\begin{tabular}{|c|c|c|c|c|c|c|c|c|c|c|c|c|c|c|c|c|c|c|c|c|c|c|c|c|c|c|c|}
\hline \multirow[b]{3}{*}{$\begin{array}{l}\text { Model } \\
\text { No. }\end{array}$} & \multirow{2}{*}{\multicolumn{8}{|c|}{ Group covariates }} & \multicolumn{16}{|c|}{ Individual covariates } & \multirow{2}{*}{\multicolumn{3}{|c|}{ Model selection results }} \\
\hline & & & & & & & & & \multicolumn{7}{|c|}{ Biological } & \multicolumn{9}{|c|}{ Operational } & & & \\
\hline & or & \pm & $\Sigma$ & $\begin{array}{l}\text { 융 } \\
\text { 응 }\end{array}$ & $\stackrel{+}{ \pm}$ & $\begin{array}{l}\text { 옹 } \\
\text { 응 } \\
\text { ț }\end{array}$ & $\begin{array}{l}\text { 옹 } \\
\frac{0}{2} \\
\text { * }\end{array}$ & 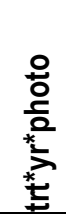 & 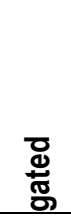 & 응 & $\begin{array}{l}\text { 응 } \\
\underset{ \pm}{*} \\
\text { ț }\end{array}$ & 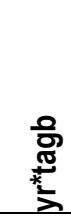 & 을 & 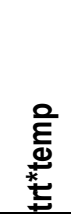 & 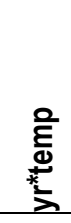 & 은 & 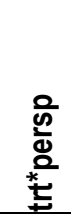 & 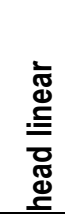 & 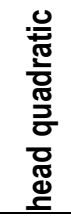 & 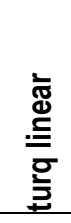 & 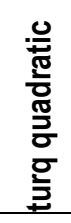 & 을 & 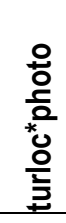 & 뭉 & $\mathrm{AlCc}$ & $\mathrm{K}$ & Deviance \\
\hline 1 & $\mathrm{x}$ & $\mathrm{x}$ & $\mathrm{x}$ & $\mathrm{x}$ & $\mathrm{x}$ & $\mathrm{x}$ & $\mathrm{x}$ & $\mathrm{x}$ & & $\mathrm{x}$ & $\mathrm{x}$ & $\mathrm{x}$ & $\mathrm{x}$ & $\mathrm{x}$ & $\mathrm{x}$ & $\mathrm{x}$ & $\mathrm{x}$ & $\mathrm{x}$ & & $\mathrm{x}$ & & $\mathrm{x}$ & $\mathrm{x}$ & $\mathrm{x}$ & 4806.9 & 62 & 4681.2 \\
\hline 2 & $\mathrm{x}$ & $\mathrm{x}$ & $\mathrm{x}$ & $\mathrm{x}$ & $\mathrm{x}$ & $\mathrm{x}$ & $\mathrm{x}$ & $\mathrm{x}$ & & $\mathrm{x}$ & $\mathrm{x}$ & & $\mathrm{x}$ & $\mathrm{x}$ & $\mathrm{x}$ & $\mathrm{x}$ & $\mathrm{x}$ & $\mathrm{x}$ & & $\mathrm{x}$ & & $\mathrm{x}$ & $\mathrm{x}$ & $\mathrm{x}$ & 4799.5 & 57 & 4684.0 \\
\hline 3 & $\mathrm{x}$ & $\mathrm{x}$ & $\mathrm{x}$ & $\mathrm{x}$ & $\mathrm{x}$ & $\mathrm{x}$ & $\mathrm{x}$ & $\mathrm{x}$ & & $\mathrm{x}$ & $\mathrm{x}$ & & $\mathrm{x}$ & $\mathrm{x}$ & & $\mathrm{x}$ & $\mathrm{x}$ & $\mathrm{x}$ & & $\mathrm{x}$ & & $\mathrm{x}$ & $\mathrm{x}$ & $\mathrm{x}$ & 4793.5 & 52 & 4688.2 \\
\hline 4 & & $\mathrm{x}$ & & $\mathrm{x}$ & & $\mathrm{x}$ & & & $\mathrm{x}$ & $\mathrm{x}$ & $\mathrm{x}$ & & $\mathrm{x}$ & $\mathrm{x}$ & & $\mathrm{x}$ & $\mathrm{x}$ & $\mathrm{x}$ & & $\mathrm{x}$ & & $\mathrm{x}$ & $\mathrm{x}$ & $\mathrm{x}$ & 4787.6 & 39 & 4709.0 \\
\hline 5 & & $\mathrm{x}$ & & $\mathrm{x}$ & & $\mathrm{x}$ & & & $\mathrm{x}$ & $\mathrm{x}$ & $\mathrm{x}$ & & $\mathrm{x}$ & $\mathrm{x}$ & & $\mathrm{x}$ & $\mathrm{x}$ & $\mathrm{x}$ & & $\mathrm{x}$ & & $\mathrm{x}$ & & $\mathrm{x}$ & 4785.9 & 38 & 4709.3 \\
\hline 6 & & $\mathrm{x}$ & & $\mathrm{x}$ & & & & & $\mathrm{x}$ & $\mathrm{x}$ & $\mathrm{x}$ & & $\mathrm{x}$ & $\mathrm{x}$ & & $\mathrm{x}$ & $\mathrm{x}$ & $\mathrm{x}$ & & $\mathrm{x}$ & & $\mathrm{x}$ & & $\mathrm{x}$ & 4791.4 & 37 & 4716.7 \\
\hline 7 & & $\mathrm{x}$ & & $\mathrm{x}$ & & $\mathrm{x}$ & & & $\mathrm{x}$ & $\mathrm{x}$ & $\mathrm{x}$ & & $\mathrm{x}$ & & & $\mathrm{x}$ & $\mathrm{x}$ & $\mathrm{x}$ & & $\mathrm{x}$ & & $\mathrm{x}$ & & $\mathrm{x}$ & 4784.1 & 37 & 4709.5 \\
\hline 8 & & $\mathrm{x}$ & & & & $\mathrm{x}$ & & & $\mathrm{x}$ & $\mathrm{x}$ & $\mathrm{x}$ & & $\mathrm{x}$ & & & $\mathrm{x}$ & $\mathrm{x}$ & $\mathrm{x}$ & & $\mathrm{x}$ & & $\mathrm{x}$ & & $\mathrm{x}$ & 4783.5 & 36 & 4711.0 \\
\hline 9 & & $\mathrm{x}$ & & & & $\mathrm{x}$ & & & $\mathrm{x}$ & $\mathrm{x}$ & $\mathrm{x}$ & & & & & $\mathrm{x}$ & $\mathrm{x}$ & $\mathrm{x}$ & & $\mathrm{x}$ & & $\mathrm{x}$ & & $\mathrm{x}$ & 4783.1 & 35 & 4712.5 \\
\hline 10 & & $\mathrm{x}$ & & & & $\mathrm{x}$ & & & $\mathrm{x}$ & $\mathrm{x}$ & $\mathrm{x}$ & & & & & $\mathrm{x}$ & & $\mathrm{x}$ & & $\mathrm{x}$ & & $\mathrm{x}$ & & $\mathrm{x}$ & 4783.5 & 34 & 4715.0 \\
\hline 11 & & $\mathrm{x}$ & & & & $\mathrm{x}$ & & & $\mathrm{x}$ & $\mathrm{x}$ & $\mathrm{x}$ & & & & & $x$ & $\mathrm{x}$ & $\mathrm{x}$ & & $\mathrm{x}$ & & $\mathrm{x}$ & & & 4790.7 & 34 & 4722.2 \\
\hline 12 & & $\mathrm{x}$ & & & & $\mathrm{x}$ & & & $\mathrm{x}$ & $\mathrm{x}$ & $\mathrm{x}$ & & & & & & $\mathrm{x}$ & $\mathrm{x}$ & & $\mathrm{x}$ & & $\mathrm{x}$ & & $\mathrm{x}$ & 4787.9 & 34 & 4719.4 \\
\hline 13 & & $\mathrm{x}$ & & & & $\mathrm{x}$ & & & $\mathrm{x}$ & $\mathrm{x}$ & $\mathrm{x}$ & & & & & $\mathrm{x}$ & $\mathrm{x}$ & $\mathrm{x}$ & & $\mathrm{x}$ & & & & $\mathrm{x}$ & 4781.1 & 34 & 4712.6 \\
\hline $14 \mathrm{a}$ & & $\mathrm{x}$ & & & & $\mathrm{x}$ & & & $\mathrm{x}$ & $\mathrm{x}$ & $\mathrm{x}$ & & & & & $\mathrm{x}$ & $\mathrm{x}$ & & & $\mathrm{x}$ & & & & $\mathrm{x}$ & 4782.3 & 33 & 4715.8 \\
\hline $14 b$ & & $\mathrm{x}$ & & & & $\mathrm{x}$ & & & $\mathrm{x}$ & $\mathrm{x}$ & $\mathrm{x}$ & & & & & $\mathrm{x}$ & $\mathrm{x}$ & & $\mathrm{x}$ & $\mathrm{x}$ & & & & $\mathrm{x}$ & 4776.7 & 35 & 4706.1 \\
\hline $15 \mathrm{a}$ & & $\mathrm{x}$ & & & & $\mathrm{x}$ & & & $\mathrm{x}$ & $\mathrm{x}$ & $\mathrm{x}$ & & & & & $\mathrm{x}$ & $\mathrm{x}$ & & $\mathrm{x}$ & & & & & $\mathrm{x}$ & 4776.6 & 34 & 4708.1 \\
\hline $15 b$ & & $\mathrm{x}$ & & & & $\mathrm{x}$ & & & $\mathrm{x}$ & $\mathrm{x}$ & $\mathrm{x}$ & & & & & $\mathrm{x}$ & $\mathrm{x}$ & & $\mathrm{x}$ & & $\mathrm{x}$ & & & $\mathrm{x}$ & 4778.6 & 36 & 4706.0 \\
\hline 16 & & $\mathrm{x}$ & & & & $\mathrm{x}$ & & & $\mathrm{x}$ & $\mathrm{x}$ & & & & & & $\mathrm{x}$ & $\mathrm{x}$ & & $\mathrm{x}$ & & & & & $\mathrm{x}$ & 4774.7 & 33 & 4708.2 \\
\hline 17 & & $\mathrm{x}$ & & & & $\mathrm{x}$ & & & & $\mathrm{x}$ & & & & & & $\mathrm{x}$ & $\mathrm{x}$ & & $\mathrm{x}$ & & & & & $\mathrm{x}$ & 4772.9 & 32 & 4708.4 \\
\hline $18 *$ & & $\mathrm{x}$ & & & & $\mathrm{x}$ & & & & & & & & & & $\mathrm{x}$ & $\mathrm{x}$ & & $\mathrm{x}$ & & & & & $\mathrm{x}$ & 4770.8 & 31 & 4708.9 \\
\hline
\end{tabular}



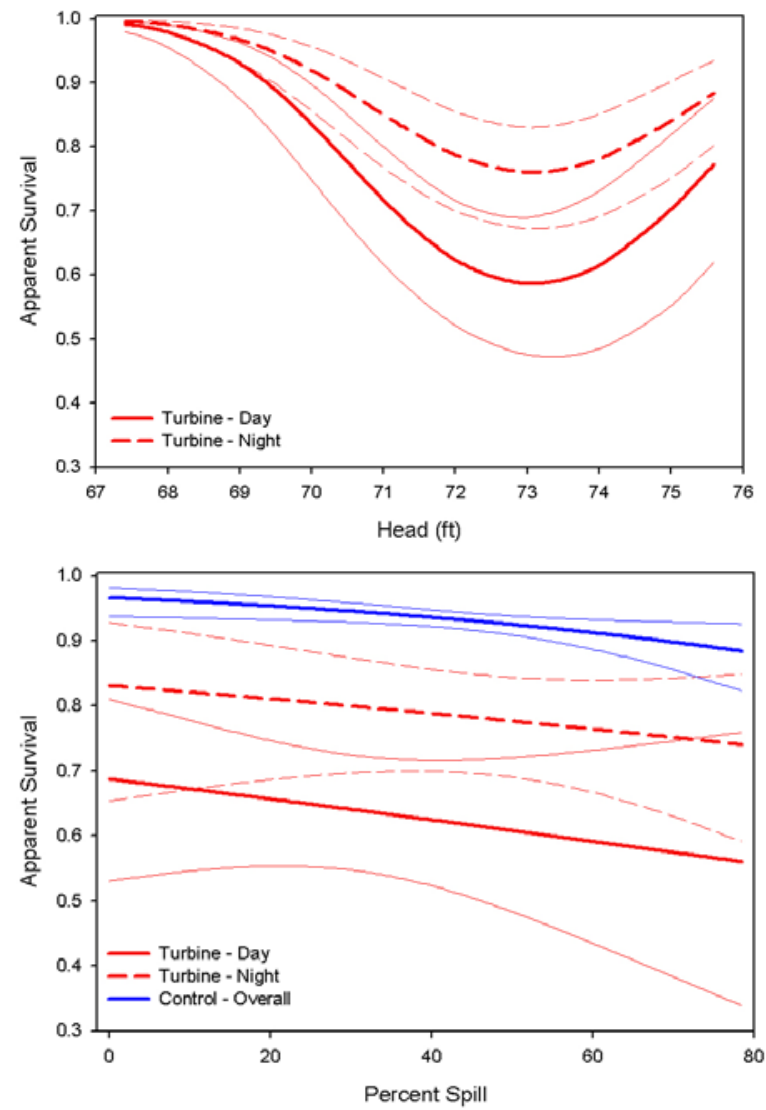

Figure 18. Graph showing estimated effects of head (upper plate) and spill percentage (lower plate) on apparent survival of juvenile steelhead at McNary Dam 2004-2009.

Table 19. Beta (slope) coefficients of estimable survival parameters of juvenile steelhead from data used in studies at McNary Dam in 2004-2009.

[The data are from model 18 in table 18]

\begin{tabular}{lrrrr} 
& & Standard & \multicolumn{2}{c}{ 95 percent confidence } \\
\cline { 4 - 5 } \multicolumn{1}{c}{ Parameter } & \multicolumn{1}{c}{ Beta } & error & Lower & \multicolumn{1}{c}{ Upper } \\
\hline intercept & 2.14319 & 0.44930 & 1.26255 & 3.02382 \\
treatment & 725.04850 & 3.69852 & 717.79939 & 732.29761 \\
treatment*photo & 0.80499 & 0.33321 & 0.15189 & 1.45809 \\
totq & 0.00516 & 0.00173 & 0.00177 & 0.00855 \\
persp & -0.01687 & 0.00695 & -0.03049 & -0.00326 \\
persp*trt & 0.00992 & 0.01124 & -0.01210 & 0.03194 \\
head & -19.88829 & 0.05170 & -19.98962 & -19.78695 \\
head $^{\wedge 2}$ & 0.13610 & 0.00068 & 0.13477 & 0.13744 \\
\hline
\end{tabular}




\section{Subyearling Chinook Salmon}

\section{Environmental Conditions}

The environmental conditions occurring during passage of subyearling Chinook salmon varied among years due to the natural hydrograph and annual evaluations at McNary Dam. The turbines usually were operated within 1 percent of peak efficiency and the data primarily were collected during turbine unit discharge from 8 to 13 thousand $\mathrm{ft}^{3} / \mathrm{s}$ (fig. 19). Covariate values at the times of fish passage are summarized in appendix Y and daily averaged values are plotted in fig. 20. Turbine unit discharge was slightly lower during 2006, 2007, and 2009 than in 2004, 2005, and 2008. Head ranged from 69.04 to $76.60 \mathrm{ft}$, with a median of $73.53 \mathrm{ft}$. Total project discharge ranged from 55.41 to 355.44 thousand $\mathrm{ft}^{3} / \mathrm{s}$ with a median of 192.58 thousand $\mathrm{ft}^{3} / \mathrm{s}$, and decreased over the study periods of most years. Spill percentage varied among years based on annual study objectives and the natural runoff, and ranged from 0.00 to 77.82 percent. Tag burden was generally similar among years, ranging from 0.68 to 7.01 percent with a median of 4.57 percent. The median tag burden was lowest in 2005 (3.82 percent) and highest in 2004 (5.12 percent). Water temperature increased throughout the study period in each year, ranging from 14.56 to $22.39^{\circ} \mathrm{C}$ over the years, with a median of $18.81{ }^{\circ} \mathrm{C}$. Water temperature was slightly lower in 2008 than in the other years.

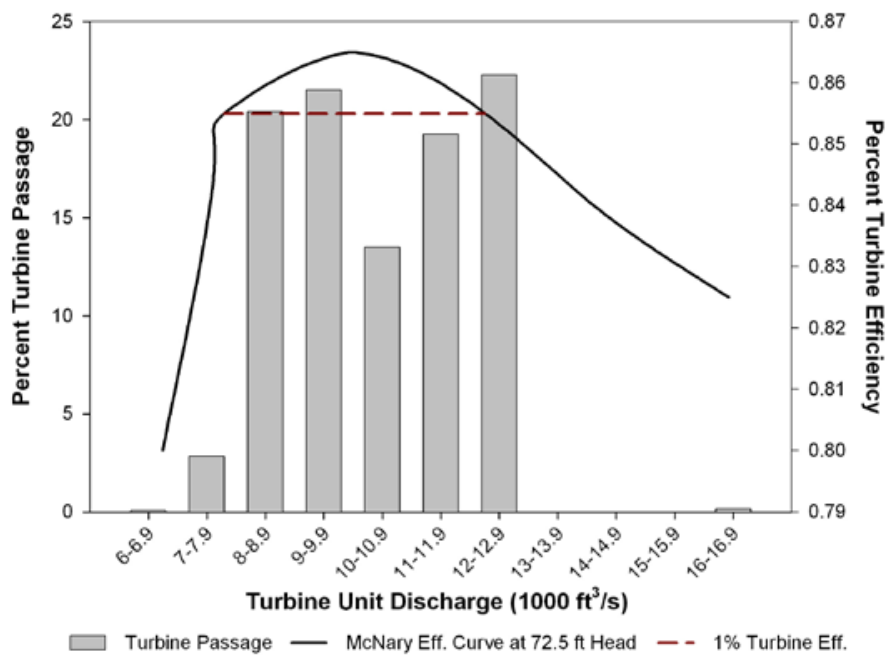

Figure 19. Graph showing turbine unit discharges during subyearling Chinook salmon passage (bars) and turbine efficiency (solid line) from data used in studies at McNary Dam in 2004-2009. The discharges bounded by the dashed line are within 1 percent of the peak turbine efficiency at a head of 72.5 feet. 

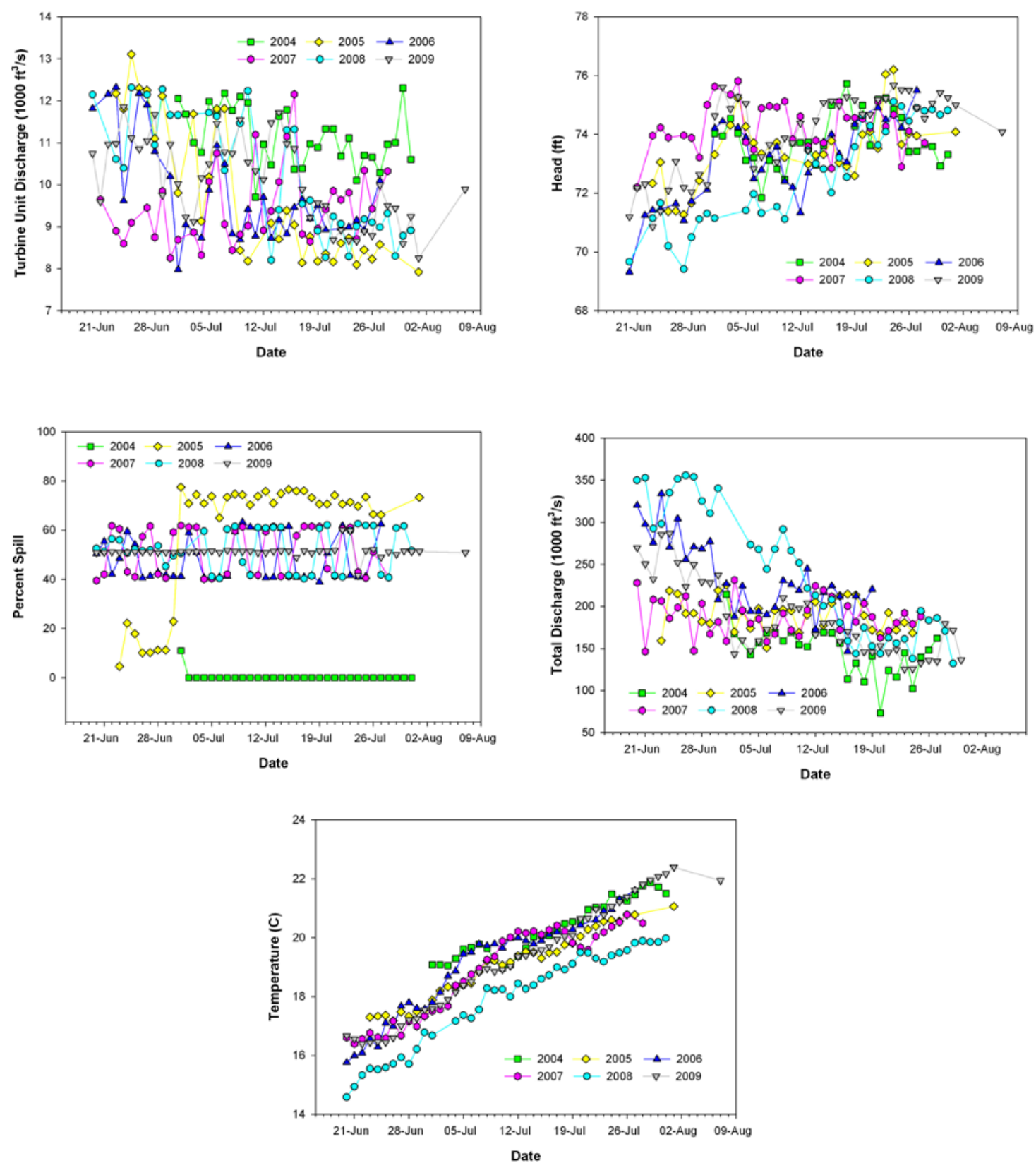

Figure 20. Graph showing daily-averaged covariate values for subyearling Chinook salmon from data used in studies at McNary Dam in 2004-2009.

Overall fish passage was similar among most turbine units, but annual differences existed. In 2004, one of the years with the largest sample sizes, most passage was through units 2-10 (fig. 21). In 2009, the pattern was nearly the opposite, with most passage occurring through units 9-14. Passage in 2005 followed a pattern similar to 2004, but the sample size was smaller. Unit-specific passage assignments were not made during the studies from 2006-2008. 


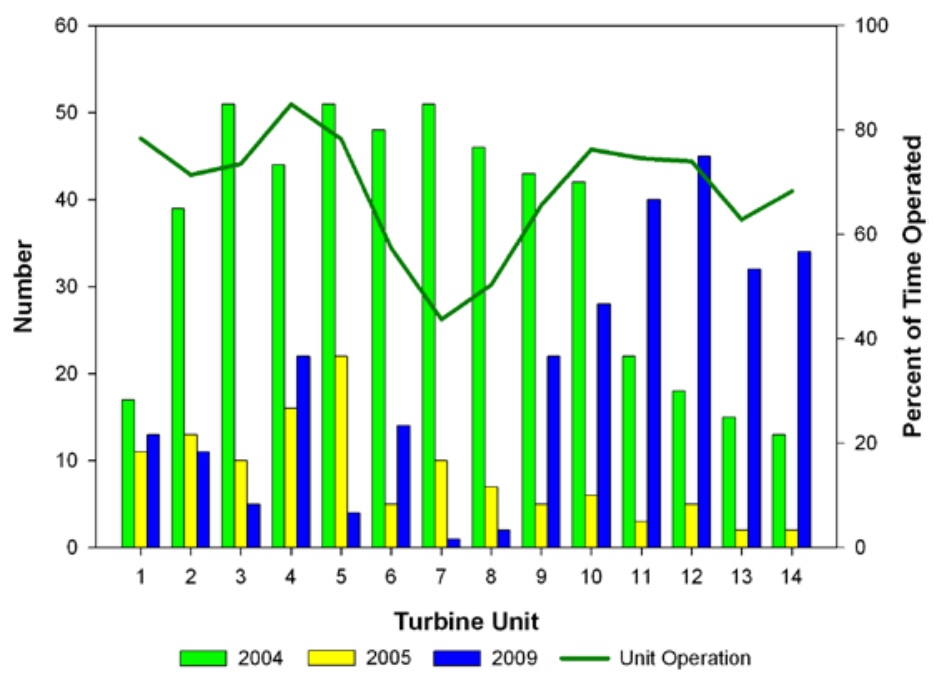

Figure 21. Graph showing number of subyearling Chinook salmon passing through each turbine by year (bars) and overall (line) from data used in studies at McNary Dam in 2004, 2005, and 2009. Unit-specific passage assignments were not made as part of the studies in 2006-2008.

\section{Survival}

As in analyses of yearling Chinook salmon and juvenile steelhead at McNary Dam, two separate analyses of data from subyearling Chinook salmon were performed due to the inconsistent resolution of the turbine unit of passage. Data from 2004, 2005, and 2009, years with unit-specific passage assignments, were analyzed first followed by analyses based on the complete data set from 2004-2009.

The analyses using years with unit-specific passage assignments were based on 890 fish in the turbine group and 2,998 fish in the control group. The turbine group in 2004 contained 2-4 times as many fish as the turbine groups in 2005 and 2009, and the control group in 2004 contained fewer fish than the other years (appendix W). Pearson correlation coefficients for fish weight and tag burden and total discharge and head ranged from $|0.47|$ to $|0.71|$ (appendix Y). Analyses of multicollinearity did not indicate any serious dependencies. As in previous analyses, we applied head only to the turbine group and total discharge to the control group. Tag burden was also treated in a similar to the other analyses, with post-hoc replacement with fish weight if an effect of tag burden was supported by the data.

A multiplicative recapture probability model of group and reach was supported by the data and used in all comparisons among survival models. This model received essentially 100 percent of the AICc weight, indicating it was the only model supported among those considered (model 1 in appendix Z). 
Four of the covariates examined were supported by the data and models as determinants of survival for the turbine group. These included tag burden, spill percentage, turbine passage location, and water temperature (appendixes AA and AB). Models with a linear or quadratic effect of head (models 13 and 14b) had AICc values 5 and 6 units greater than the model having no head effect (model 14a) indicating no support for these models. Similarly, models with linear or quadratic effects of turbine unit discharge (models 14a and 15b) had AICc values 2 and 3 units greater than the model without turbine unit discharge (model 15a). Because an effect of turbine unit discharge on survival was not supported, further analyses were based on the complete 2004-2009 data set.

The analyses of factors affecting survival for all years (2004-2009) were based on 1,912 fish in the turbine group and 6,547 in the control group (appendix AC). Numbers of fish in the turbine groups ranged from 117 to 500 fish among years, whereas annual control fish numbers ranged from 763 to 1,191 . No control fish were released at night in 2006 or 2008.

Correlation analyses indicate that several variables were moderately related. Pearson correlation coefficients ranged from $|0.63|$ to $|0.72|$ for fish weight and tag burden and was $|0.69|$ for total discharge and head (tables 20 and 21). The correlation coefficient for total discharge and water temperature was $|0.69|$. We applied the head covariate only to the turbine group and total discharge only to the control group. Tag burden was applied to turbine and control groups. As in analyses of yearling Chinook salmon at McNary Dam, specific turbine unit passage location used in the reduced data set was replaced by a north or south passage location for all years, because that was the only resolution common to all years.

A multiplicative recapture probability model of group and reach was supported by the data and used in all comparisons among survival models. This model received greater than 99.9 percent of the AICc weight, indicating that it was the only model supported among those considered (model 1 in appendix AD). Recapture probabilities at the first downriver site ranged from 0.345 (SE 0.095) to 0.996 (SE 0.004) and averaged 0.779. The $\lambda$ parameter ranged from 0.573 (SE 0.043) to 0.953 (SE 0.045) and averaged 0.796. Survival effects of spill percentage and water temperature were the only individual covariates supported by the data and models (table 22). Operational covariates other than spill percentage contributed little to the fit of the survival models. The linear and quadratic models of head (model 13 and 14b) had AICc values 1.8 and 3.8 greater than the model with no head effect (model 14a) indicating no support for this covariate. Turbine unit discharge was also not supported; with linear and quadratic models having AICc values 2 and 4 units greater than the model without turbine unit discharge (models $14 \mathrm{a}$ and $15 \mathrm{~b}$ compared to model 15a). Among the models examined, the model containing treatment, photoperiod, year, 2-way interactions, and the individual covariates of water temperature and spill percentage were supported (model 17 in table 22). 
Table 20. Table of correlation indices of data from subyearling Chinook salmon from the turbine group from data used in studies at McNary Dam in 2004-2009.

[Pearson correlation coefficients are listed above the probabilities of obtaining a greater value under the hypothesis that $\mathrm{Rho}=0$. Sample size is 1,$912 ;<$, less than; see table 2 for variable name definitions]

\begin{tabular}{|c|c|c|c|c|c|c|c|c|c|}
\hline & TOTQ & PER_SPI & HEAD & TUQ & UNITLOC & РНОTO & TEMP & WEIGHT & $\begin{array}{c}\text { TAG } \\
\text { BURDEN }\end{array}$ \\
\hline \multirow[t]{2}{*}{ TотQ } & 1.0000 & 0.4719 & -0.6881 & 0.3034 & -0.1285 & -0.3848 & -0.6972 & -0.2939 & 0.0607 \\
\hline & & $<0.0001$ & $<0.0001$ & $<0.0001$ & $<0.0001$ & $<0.0001$ & $<0.0001$ & $<0.0001$ & 0.0079 \\
\hline \multirow[t]{2}{*}{ PER_SPI } & & 1.0000 & -0.0623 & -0.3898 & -0.1087 & -0.0955 & -0.3069 & -0.2425 & -0.2020 \\
\hline & & & 0.0065 & $<0.0001$ & $<0.0001$ & $<0.0001$ & $<0.0001$ & $<0.0001$ & $<0.0001$ \\
\hline \multirow[t]{2}{*}{ HEAD } & & & 1.0000 & -0.3611 & 0.0391 & 0.3604 & 0.5204 & 0.2378 & -0.0674 \\
\hline & & & & $<0.0001$ & 0.0877 & $<0.0001$ & $<0.0001$ & $<0.0001$ & 0.0032 \\
\hline \multirow[t]{2}{*}{ TUQ } & & & & 1.0000 & 0.0573 & -0.2433 & -0.2106 & 0.0336 & 0.0740 \\
\hline & & & & & 0.0122 & $<0.0001$ & $<0.0001$ & 0.1421 & 0.0012 \\
\hline \multirow[t]{2}{*}{ UNITLOC } & & & & & 1.0000 & 0.0050 & 0.0441 & 0.0029 & 0.0129 \\
\hline & & & & & & 0.8275 & 0.0540 & 0.8979 & 0.5718 \\
\hline \multirow[t]{2}{*}{ РнОТО } & & & & & & 1.0000 & 0.2242 & 0.1092 & -0.0255 \\
\hline & & & & & & & $<0.0001$ & $<0.0001$ & 0.2654 \\
\hline \multirow[t]{2}{*}{ TEMP } & & & & & & & 1.0000 & 0.3102 & -0.0909 \\
\hline & & & & & & & & $<0.0001$ & $<0.0001$ \\
\hline \multirow[t]{2}{*}{ WEIGHT } & & & & & & & & 1.0000 & -0.7196 \\
\hline & & & & & & & & & $<0.0001$ \\
\hline
\end{tabular}


Table 21. Table of correlation indices of data from subyearling Chinook salmon from the control group from data used in studies at McNary Dam in 2004-2009.

[Pearson correlation coefficients are listed above the probabilities of obtaining a greater value under the hypothesis that $\mathrm{Rho}=0$. Sample size is 6,$547 ;<$, less than; see table 2 for variable name definitions]

\begin{tabular}{|c|c|c|c|c|c|c|}
\hline & TOTQ & PER_SPI & РНОTO & TEMP & WEIGHT & $\begin{array}{c}\text { TAG } \\
\text { BURDEN } \\
\end{array}$ \\
\hline \multirow[t]{2}{*}{ TOTQ } & 1.0000 & 0.2798 & -0.2329 & -0.6861 & -0.2086 & 0.1625 \\
\hline & & $<0.0001$ & $<0.0001$ & $<0.0001$ & $<0.0001$ & $<0.0001$ \\
\hline \multirow[t]{2}{*}{ PER_SPI } & & 1.0000 & -0.0436 & -0.1374 & -0.2374 & -0.2019 \\
\hline & & & 0.0004 & $<0.0001$ & $<0.0001$ & $<0.0001$ \\
\hline \multirow[t]{2}{*}{ РнОТО } & & & 1.0000 & 0.1202 & 0.0094 & -0.1284 \\
\hline & & & & $<0.0001$ & 0.4493 & $<0.0001$ \\
\hline \multirow[t]{2}{*}{ TEMP } & & & & 1.0000 & 0.2608 & -0.2156 \\
\hline & & & & & $<0.0001$ & $<0.0001$ \\
\hline \multirow[t]{2}{*}{ WEIGHT } & & & & & 1.0000 & -0.6296 \\
\hline & & & & & & $<0.0001$ \\
\hline
\end{tabular}

A negative effect of water temperature was moderately supported for fish in turbine and control groups and a negative effect of spill percentage was weakly supported for fish in the turbine group. A negative effect of water temperature on survival was supported for all years except for 2005 in which the effect was positive (table 23, fig. 22). The model slopes generally indicate a greater temperature effect on the turbine group than the control group. Survival estimates of the control group were higher than for the turbine group, as expected. Spill percentage had a negative effect on survival of the turbine group in all years (fig. 23). The effect of photoperiod varied among years, with some years having higher survival during the day than at night, and other years with the opposite trend. 


\section{Key Findings in Data from Subyearling Chinook Salmon at McNary Dam}

- Initial analyses were based on a subset of the data because turbine unitspecific passage location was not available in all years. Unit-specific discharge was not supported as a factor on survival in these data (from 2004, 2005, and 2009), so inferences were based on the full 2004-2009 data set and a "north-south" assignment for unit passage location.

- The full data set included 1,912 fish in the turbine group and 6,547 fish in the control group.

- Most data were collected at turbine discharges within 1 percent of peak unit efficiency.

- A negative effect of spill percentage was weakly supported as a factor affecting turbine passage survival.

- An effect of water temperature on survival was moderately supported. The effect was positive in 2005 and negative in all other years.

- An effect of tag burden on survival was not supported. 
Table 22. Model-selection results from radio- and acoustic-tagged subyearling Chinook salmon from data used in studies at McNary Dam in $2004-2009$.

[Presence of a factor in a model is indicated by an ' $\mathrm{x}$ ' in the column for that factor. Model 1 was a global model including all group covariates and their interactions (g) as well as all individual covariates and interactions listed. All models shared a common $\mathrm{g} *$ reach model of recapture probability. K indicates the number of parameters. An asterisk after the model number indicates the best-supported model of the suite]

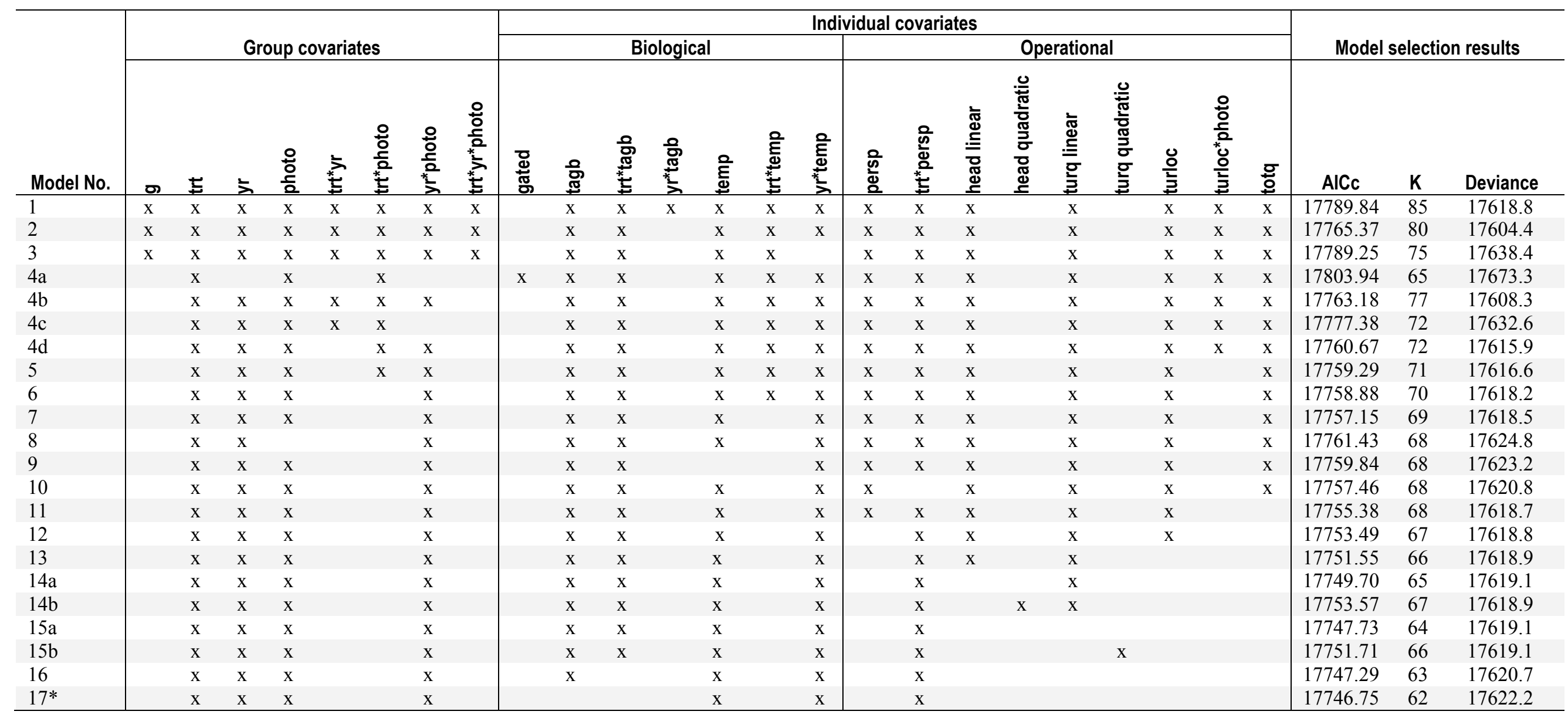


Table 23. Beta (slope) coefficients of estimable survival parameters of subyearling Chinook salmon from data used in studies at McNary Dam in 2004-2009.

[The data are from model 17 in table 22]

\begin{tabular}{|c|c|c|c|c|}
\hline \multirow[b]{2}{*}{ Parameter } & \multirow[b]{2}{*}{ Beta } & \multirow{2}{*}{$\begin{array}{c}\text { Standard } \\
\text { error }\end{array}$} & \multicolumn{2}{|c|}{95 percent confidence } \\
\hline & & & Lower & Upper \\
\hline intercept & 6.46134 & 1.91771 & 2.70263 & 10.22004 \\
\hline treatment & -0.92842 & 0.15768 & -1.23748 & -0.61937 \\
\hline photo & -0.51201 & 0.18596 & -0.87649 & -0.14753 \\
\hline 2005 & -7.14920 & 2.69855 & -12.43835 & -1.86005 \\
\hline 2006 & 4.65938 & 2.39320 & -0.03129 & 9.35005 \\
\hline 2007 & 1.45289 & 2.74781 & -3.93282 & 6.83860 \\
\hline 2008 & 3.43575 & 2.41183 & -1.29143 & 8.16293 \\
\hline 2009 & 6.13040 & 2.23710 & 1.74567 & 10.51512 \\
\hline photo $* 2005$ & 0.68992 & 0.31715 & 0.06831 & 1.31153 \\
\hline photo*2006 & 0.67572 & 0.31164 & 0.06490 & 1.28654 \\
\hline photo $* 2007$ & -0.41557 & 0.33937 & -1.08073 & 0.24960 \\
\hline photo $* 2008$ & 1.30430 & 0.39638 & 0.52739 & 2.08120 \\
\hline photo*2009 & 0.28627 & 0.25838 & -0.22015 & 0.79269 \\
\hline persp*treatment & -0.00756 & 0.00353 & -0.01448 & -0.00063 \\
\hline temp & -0.22686 & 0.09441 & -0.41191 & -0.04181 \\
\hline temp $* 2005$ & 0.37577 & 0.13996 & 0.10145 & 0.65008 \\
\hline temp $* 2006$ & -0.23237 & 0.12016 & -0.46789 & 0.00315 \\
\hline temp $* 2007$ & -0.05709 & 0.13775 & -0.32707 & 0.21289 \\
\hline temp*2008 & -0.19011 & 0.12272 & -0.43064 & 0.05043 \\
\hline temp*2009 & -0.29683 & 0.11036 & -0.51313 & -0.08053 \\
\hline
\end{tabular}



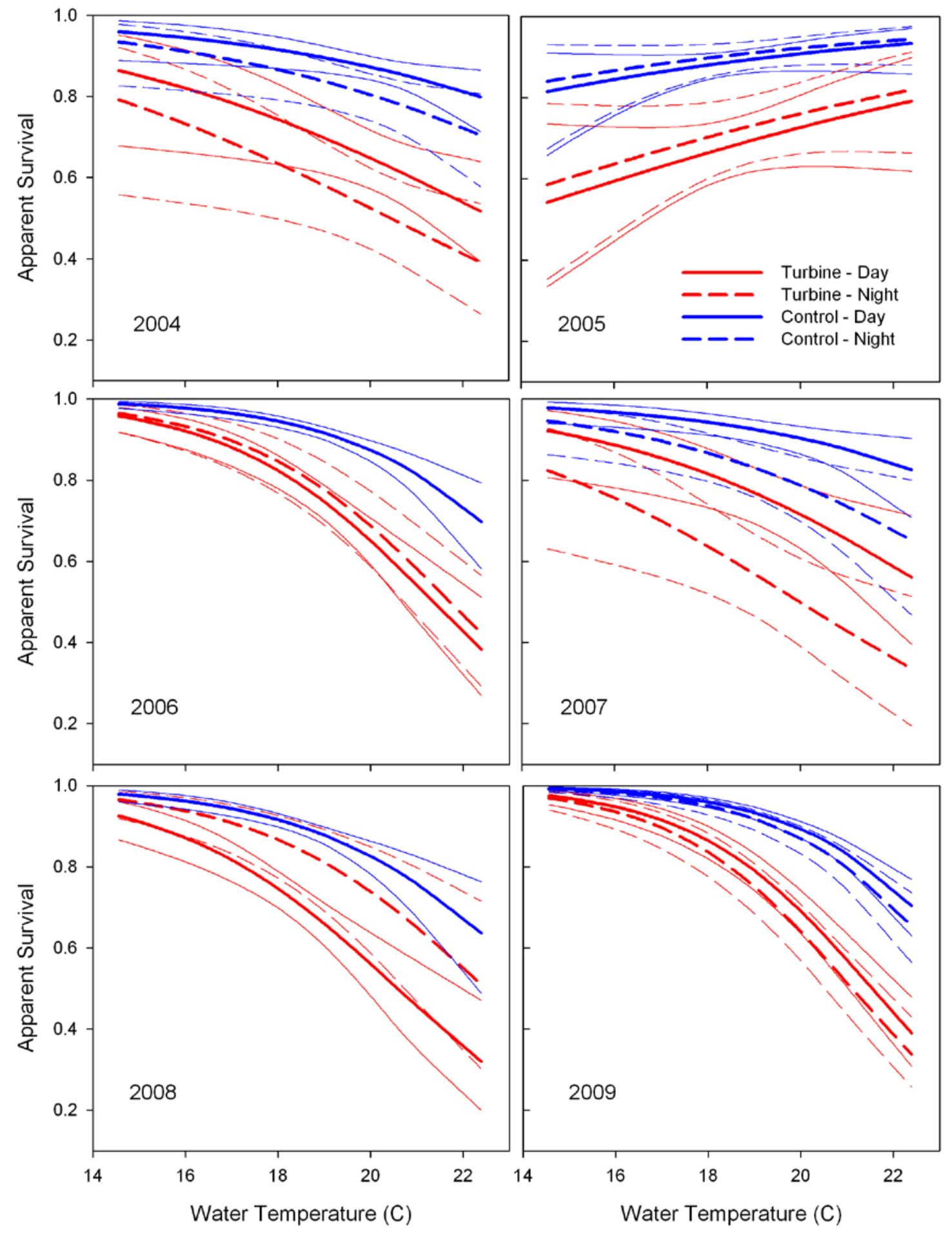

Figure 22. Graph showing estimated effects of water temperature on apparent survival of subyearling Chinook salmon from data used in studies at McNary Dam in 2004-2009. Predictions (thick lines) and 95 percent confidence intervals (thin lines) from model 17 in table 22 are plotted. 

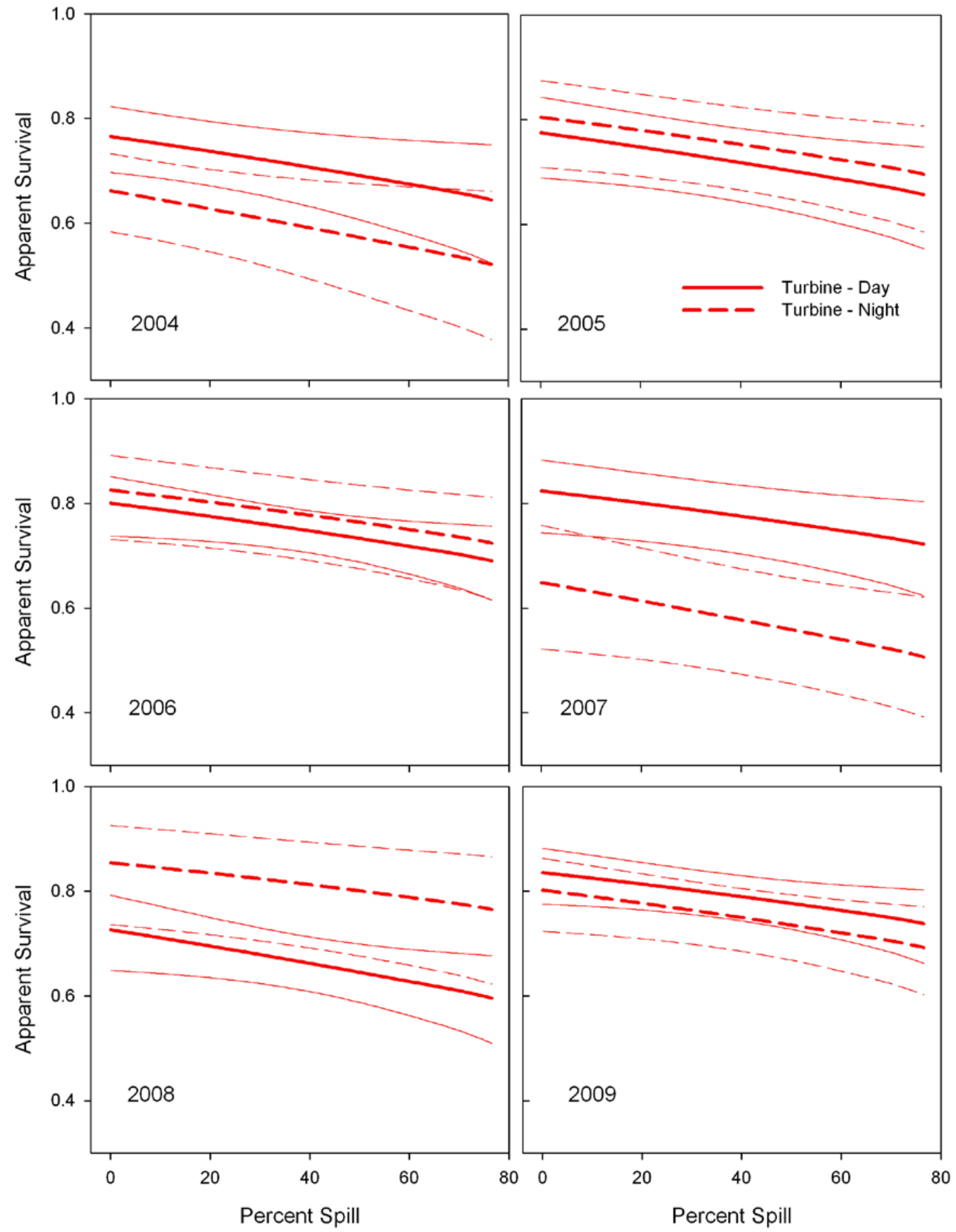

Figure 23. Graph showing estimated effects of spill percentage on apparent survival of subyearling Chinook salmon from data used in studies at McNary Dam in 2004-2009. Predictions (thick lines) and 95 percent confidence intervals (thin lines) from model 17 in table 22 are plotted. 


\section{Discussion}

Results of our analyses indicate the survival of tagged fish passing turbines was primarily affected by factors unrelated to turbine operation. Effects of water temperature were supported in four of the five data sets and were strongly supported in all but one. Tag burden was strongly supported in data from yearling Chinook salmon, but not in data from subyearling Chinook salmon or juvenile steelhead. Spill percentage, head, and turbine unit discharge received weak or moderate support in some cases. These findings are similar to results from several other studies of juvenile salmonids passing through turbines in the Columbia River Basin. Studies of turbine passage in the Columbia River Basin have most commonly been controlled field experiments based on fish fitted with balloon tags (Heisey and others, 1992). These studies generally find small and often statistically insignificant differences among fish survival at different turbine unit discharges, yet some show small, but statistically significant differences.

Our results are similar to those of Ferguson and others (2006), who reported estimates of survival of turbine-passed fish from concurrent studies of controlled turbine unit discharges based on radio telemetry and balloon tags at McNary Dam. They reported that both methods found small, statistically insignificant, differences between survival of juvenile salmonids passing turbine unit 9 operated at discharges of 11.2 thousand $\mathrm{ft}^{3} / \mathrm{s}$ and 16.4 thousand $\mathrm{ft}^{3} / \mathrm{s}$. Results based on balloon tags, which incorporate primarily direct mortality sources, were 0.930 (SE 0.021) at the lower discharge and 0.946 (SE 0.019) at the higher discharge. Examples of direct mortality sources from turbine passage include strike, shear, and barotrauma (Cada, 2001). Estimates of survival based on the radio-telemetry method, incorporating direct and indirect mortality sources from turbine passage to the release point of a control group of fish $2 \mathrm{~km}$ downstream, were 0.871 (SE 0.016) and 0.856 (SE 0.011) at the lower and higher discharge levels, respectively. Examples of indirect, or delayed, mortality include predation on dead, moribund, or healthy fish (Mesa and others, 1994). Predaceous fish pose a significant source of mortality of juvenile salmonids in the Columbia River Basin (Rieman and others, 1991; Ward and others 1995). Faler and others (1988) determined that northern pikeminnow (Ptychocheilus oregonensis) were opportunistic predators in the tailrace of McNary Dam, moving quickly into near-dam areas as dam operations changed. Avian predators are also important predators (Ryan and others, 2001). Ferguson and others (2006) suggested that delayed mortality comprised 46-70 percent of the total estimated juvenile salmon mortality from turbine passage at McNary Dam. Our methods are similar to those of Ferguson and others (2006) in that we used data from studies incorporating direct and indirect sources of mortality, but differ from their methods by not controlling turbine discharges. The methods also differ analytically: we examined what may be considered observational data for specific trends, such as linear or quadratic fits, and Ferguson and others (2006) estimated survival at specific operating points from a controlled experiment.

Our finding of infrequent support for the turbine operation factors on survival is consistent with results of most controlled experiments. Evaluations of specific turbine discharges often find a numerical optimum in terms of fish survival, but the ranges in survival across test discharges are small and generally not statistically different. For example, Normandeau Associates and others (2003) estimated direct survival of balloon-tagged fish released into turbine intakes at McNary Dam and found no significant differences among estimates of survival of fish when the turbine was operated at four discrete levels from 8.0 to 16.4 thousand $\mathrm{ft}^{3} / \mathrm{s}$, with survival estimates ranging from 0.930 to 0.983 . Similar results were found at other Columbia and Snake River dams (Mathur and others, 2000; Skalski and others, 2002a; Normandeau Associates and others, 2008a, 2008b). Additionally, the ranges of survival in these controlled studies are 
small. In four studies at Columbia or Snake River dams, Skalski and others (2002a) determined that estimates of fish survival generally differed by less than 5 percent over the range of unit discharges tested. In our analyses, a quadratic model of turbine unit discharge was weakly supported for subyearling Chinook salmon passing turbines at John Day Dam, but linear or quadratic effects were not supported for any other group. The effect size from lowest to highest survival from the relation at John Day Dam over the range of turbine discharges we examined was 11.2 to 13.9 percent (that is, a difference in survival probabilities of $0.112-0.139$ ) for fish passing during the day and 20.5-24.5 percent for those passing at night. We estimated the peak survival of subyearling Chinook salmon at John Day Dam occurred at a turbine discharge of 15.9 thousand $\mathrm{ft}^{3} / \mathrm{s}$, but the 95 percent confidence interval ranged from -1.7 to 33.7 thousand $\mathrm{ft}^{3} / \mathrm{s}$, indicating the estimate was imprecise. This may be due to the broad range of turbine discharges within 1 percent of peak unit efficiency at John Day Dam.

Results from this study likely will be compared to the studies of turbine survival based on balloon tags, but the methods used in studies we examined differ from balloon tag studies in five primary ways. First, the fish used in this work were released into the Columbia River about 10$20 \mathrm{~km}$ upstream from the dams and are assumed to be depth-acclimated by the time they reach the dam. That depth, assumed to be the depth of neutral buoyancy, is not known, but Beeman and Maule (2006) estimated mean in-situ migration depths of radio-tagged juvenile Chinook salmon to be $3.2 \mathrm{~m}$ and juvenile steelhead to be $2.3 \mathrm{~m}$ in McNary Reservoir slightly upstream from McNary Dam. The fish used in studies based on balloon tags are acclimated to near-surface depths, because they are removed directly from a shallow tank, fitted with the balloon and other tags, and released into a hose leading to the turbine intake or runner. Brown and others (2009) and Carlson and others (2010) determined that in controlled laboratory conditions simulating pressure changes that may occur during turbine passage that the depth of acclimation (that is, neutral buoyancy) was an important factor in subsequent signs of mortal injury. They determined that signs of mortal injury increased with acclimation depth, suggesting that data from studies using balloon-tags will underestimate passage mortality and the data we examined would be more representative of run-of-river fish.

Second, the data we examined were based on fish volitionally entering turbine intakes and data from balloon tag studies were based on fish passed into turbine intakes or runners through hoses. This is an important distinction, because the elevation of entry into a turbine intake may affect area of turbine passage and fish survival. Normandeau Associates and others (1996) as reported in Skalski and others (2002a) detected significantly different survival of fish from releases made at different depths within the turbine intakes at Wanapum Dam on the Columbia River. Conversely, Mathur and others (1996, 2000) detected no statistically significant difference in survivals when releasing fish into turbine intakes at different elevations at other dams. Thus, interpretations of results from studies based on fish released through hoses may be affected by potential differences between fish release locations and location of passage of the untagged population. The vertical distribution of fish volitionally entering turbines is not known, but is likely different from the distribution of fish released from a hose. The availability of data from fish volitionally entering turbine intakes was one of the reasons our analyses were conducted. 
Third, mortality in studies based on balloon tags only address direct effects and our analyses included direct and indirect effects. By recapturing fish floated to the surface shortly after turbine passage, studies using balloon tags do not generally incorporate indirect effects of turbine passage, such as predation by fishes or birds. The estimates of survival in our analyses therefore are expected to be lower than those of studies based on balloon tags, which is consistent with our results. Ferguson and others (2006) also detected lower survival in groups incorporating direct and indirect sources of mortality compared to those from a balloon tag study at McNary Dam. The inclusion of indirect effects may dilute the effects of turbine discharge sometimes found in controlled studies of direct survival.

Fourth, studies based on balloon tags are carefully designed and controlled studies of turbine unit discharge, whereas turbine unit discharges were not controlled during collection of the data we used. The data we used were collected during studies controlling structures or operations at the spillway rather than at the powerhouse and were collected primarily during operation within one percent of the peak turbine efficiency (the "1 percent" rule). The ramifications of reliance on data collected predominantly within the 1 percent rule vary depending on the efficiency curve of the turbines being studied. For example, at John Day Dam the generator limit (21.3 thousand $\mathrm{ft}^{3} / \mathrm{s}$ at a head of $102 \mathrm{ft}$ ) is near the upper end of the 1 percent rule (21.6 thousand $\mathrm{ft}^{3} / \mathrm{s}$ at a head of $102 \mathrm{ft}$ ), but at McNary Dam considerable operational range exists between the upper end of the 1 percent rule $\left(12.4\right.$ thousand $\mathrm{ft}^{3} / \mathrm{s}$ at a head of $73 \mathrm{ft}$ ) and the generator limit (16.2 thousand $\mathrm{ft}^{3} / \mathrm{s}$ at ahead of $73 \mathrm{ft}$ ). The uncontrolled nature of the turbine discharges represents an important difference between the studies, and was one reason we selected the information-theoretic method of analysis.

Fifth, our results are based on fish carrying transmitters internally and the balloon-tag studies are based on fish carrying balloon tags and transmitters externally. There is evidence from this study and others that the method of tag attachment (internal or external) is likely to affect the effect of tag burden on survival of fish passing turbines due to the mechanism of injury from barotrauma. A common cause of injury in juvenile salmonids exposed to rapid decompression, such as that during turbine passage, is from the expansion of the swim bladder and gas-laden tissues causing trauma to the swim bladder and internal organs (Brown and others, 2009). This is exacerbated as the volume of the swim bladder prior to exposure increases and as the space it can expand into decreases. Swim bladder volume increases with acclimation depth and tag burden, regardless of tag attachment method, so this effect is similar in both study types with similar tag burdens. However, the space the swim bladder can expand into is reduced by the use of internal placement of transmitters and is different in studies of balloon tags (external attachment) and the data we examined (internal attachment). Brown and others (2009) found this to be true for transmitters placed internally with either gastric or surgical methods, both of which are present in the data we examined. This suggests that the turbine-passage survival of fish with internal transmitters will be lower than fish with external transmitters, which is consistent with empirical data (for example Ferguson and others, 2006). These results support the commonlyheld hypothesis that one of the differences between results of balloon tag studies and active-tag studies of dam-passage survival is the inclusion of indirect sources of mortality in results from active-tag studies, but indicates that some part of what has been called "indirect mortality" actually may be direct plus indirect mortality caused by the method of tag attachment. Our analyses support this premise for yearling Chinook salmon at McNary Dam and potentially at John Day Dam. 
We used information-theoretic methods to determine which factors produced effects supported by the data rather than statistical null-hypothesis testing with strict "significance" cutoffs. We created models representing a priori hypotheses and used information-theoretic methods to determine the strength of evidence from the data, given the models, to determine which factors were supported as affecting survival of tagged fish passing turbines. Our analyses were not based on controlled experiments manipulating the operational factors while controlling for others and thus frequentist statistics were not appropriate (Burnham and Anderson, 2002). There is no strict cutoff of importance in information-theoretic methods, which is one of the reasons we selected the method. Rather, differences in AICc (or other measures of parsimony) represent a continuous scale of the support of models (hypotheses) by the data. Our use of this method was more dichotomous than in some applications, and might be considered akin to a series of stepwise comparisons. However, the factors considered and the order of model comparisons were determined a priori through consultation of experts in turbine design and operation, fishery management, and fishery research, and thus our use was consistent with the information-theoretic approach. Our goal in this study was to determine if the selected factors were supported as having effects on survival, which is not logically a "yes" or "no" question.

We did not estimate overdispersion, but varying the overdispersion parameter $(\hat{c})$ did not appreciably alter the primary conclusions from the analyses. Mark-recapture data are based on theoretical models assuming subjects behave as individuals rather than as groups. An estimate of $\hat{c}$ is 1 if individuals behave independently, 2 if they behave as pairs (for example, breeding pairs of Canada geese), 3 if they behave as triplets, and so on. A $\hat{c}$ of 3 would be considered high (Burnham and Anderson, 2002). Estimates of $\hat{c}$ are generally based on some form of deviance divided by the degrees of freedom and a chi-square goodness of fit test based on groups of individuals with like capture histories. However, in the presence of individual covariates, the typical analyses are not possible, because all individuals can be uniquely identified, and thus there are no groups. Pollock (2002) and White (2002) discuss this problem and suggest the estimation of $\hat{c}$ in the presence of individual covariates as a topic requiring further research. We selected the approach used by Devries and others (2003), and examined the effects on the study conclusions over hypothetical $\hat{c}$ values of 1 and 3 . An adjustment to the AICc and parameter variances favoring models with fewer parameters is made when $\hat{c}$ is greater than 1 . This adjustment can affect interpretation of the support for modeled hypotheses, so is usually of primary importance. The primary conclusions from analyses of data from John Day Dam remained similar at $\hat{c}$ values of 1 and 3 , although the level of support was reduced at the higher value. For example, the change in AICc when removing the strongly supported tag burden effect in the yearling Chinook salmon analyses was -18.3 when $\hat{c}$ was 1 and -14.9 when it was 3 . However, the delta AICc of the weakly supported quadratic effect of turbine unit discharge in the subyearling Chinook salmon analyses was -1.3 when $\hat{c}$ was set to 1 and +2.2 when it was 3 , changing the conclusion from weakly supported to not supported (recall the quadratic effect requires two parameters, so a delta AICc of 2-4 would be required to indicate no support). The primary conclusions from McNary Dam were also changed only slightly at a $\hat{c}$ value of 3 . The most supported conclusion, that tag burden affected survival of yearling Chinook salmon, was unchanged. Increasing $\hat{c}$ to 3 reduced or removed support for factors that were weakly or moderately supported in the original analyses, such as year, photoperiod, spill percentage, and head. 
Our results suggest tag burden is an important factor affecting survival of yearling Chinook salmon at John Day and McNary dams. Data from John Day Dam strongly supported an effect of tag burden on control fish and data from McNary Dam strongly supported an effect on control and turbine fish. The lack of support for an effect on yearling Chinook salmon turbine fish at John Day Dam may be from the sparseness of the data: there were 246 turbine fish and 2,973 control fish in the data set from John Day Dam and 1,419 turbine fish and 6,737 control fish at McNary Dam. The simulated effect on control fish was similar between dams and was much less than the simulated effect on turbine fish at McNary Dam.

We detected little evidence to suggest tag burden affects survival of turbine passing juvenile steelhead or subyearling Chinook salmon. Effects of tag burden on turbine passage survival of juvenile steelhead and subyearling Chinook salmon at McNary Dam received weak to moderate support in analyses of the restricted set of years from McNary Dam (2004, 2005, and 2009), indicating some evidence for an effect, but when the entire 2004-2009 data set was examined an effect of tag burden was not supported in these groups. The effect may be initially expected to be greatest in subyearling Chinook salmon, because they are physically smaller than the other fish studied, but the tag burden was similar in yearling and subyearling Chinook salmon due to different tags sizes used in each group. Therefore, there is no basis for a greater effect in subyearling Chinook salmon based on differences in tag burden. However, Brown and others (2009) reported more frequent mortality and signs of injury in radio-tagged subyearling Chinook salmon than in yearling Chinook salmon after simulated turbine passage and suggested the difference was due to the differences in fish sizes. Perhaps the lower turbine-passage survival of subyearling Chinook is primarily due to factors apart from tag burden, such as the effects of fish size and barotrauma described by Brown and others (2009) or other environmental factors. As in data we examined, tag burdens in the yearling and subyearling Chinook salmon groups studied by Brown and others (2009) were similar because different size tags were used in the two groups. A lack of support for the tag burden effect in juvenile steelhead might be expected, because their large size relative to the Chinook salmon resulted in a lower tag burden (median 1.89 percent) than the other groups (median 4.35 percent or greater). Turbine passage survival could also vary due to differences in the pressures along the paths different species or races of fish take as they pass through turbines.

The negative effects of tag burden supported in our analyses are generally consistent with those of the laboratory experiments of Brown and others (2009) and Carlson and others (2010). However, Carlson and others (2010) likely overestimated the effect of tag burden when using data from field-based studies to illustrate the potential effect of tag burden on survival. The source of mortality in their laboratory study of simulated turbine passage was barotrauma. However, the mortality of turbine-passing fish in field studies includes mortality from barotrauma, strike, shear, and other direct effects of turbine passage as well as indirect effects of turbine passage affecting predation after passage. Thus, one cannot use survival estimates from field studies of turbine-passing fish to correctly back-calculate the likely pressure history during turbine passage using results of Carlson and others (2010) without separating the mortality from barotrauma and mortality from other causes. Failing to do so overestimates the log ratio of pressure change during turbine passage described by Carlson and others (2010), which will then overestimate the mortality of tagged fish relative to untagged fish. The bias in using data from field studies of turbine passage to illustrate the effects of tag burden from the laboratory experiments of Carlson and others (2010) increases with tag burden. The proportion of turbinepassage mortality that may be attributed to sources other than barotrauma following passage is 
likely to be an important component of the total mortality. Petersen (1994) and Ward and others (1995) found that much of the reservoir-wide predation of juvenile salmonids by predaceous fishes occurs in the relatively small spatial area near hydro dams, and predation by avian predators is also high in these areas.

We were not able to separate effects of tag burden and fish weight using the data available. Tag burden and fish weight were inextricably confounded in our analyses, preventing us from determining their independent effects. Replacing tag burden with fish weight in models of yearling Chinook salmon at John Day and McNary dams resulted in ambiguous results, suggesting weight was the more supported factor in one case and tag burden was the more supported factor in the other. However, results from the controlled laboratory experiments of Carlson and others (2010), indicated fish weight was not an important contributor to the fit of models describing an index of mortal injury, lending support to tag burden as the causative factor in our analyses.

Additional controlled field experiments of factors affecting juvenile salmonid are needed to assess turbine survival. We feel most studies have been too narrowly focused to add substantially to the knowledge base on the subject. For example, most studies have examined turbine passage survival relative to the 1 percent rule and thus often only have three turbine discharge levels in their design (see Skalski and others [2002a] for a description of four studies). These studies aid the quest for information about survival relative to the 1 percent rule, but do little to answer what we see as the larger question, which is whether there is a reproducible pattern between turbine discharge and survival. We suggest future studies be designed with at least four discharge levels spanning the entire operating range of turbine discharge and that the results be examined relative to a priori hypotheses such as linear or curvilinear patterns, rather than tests of statistical significance among operating points. The study conducted by Normandeau and Associates and others (2008a) exemplifies this approach. They estimated survival at each of five turbine discharge levels at Ice Harbor Dam on the Snake River. They concluded no statistical difference existed in survival among the five levels (although the data from the peak discharge was not used in the analysis due to a single test condition), but there was a clear curvilinear relation with a maximum at the intermediate discharge level. Their effect sizes were insufficient to result in statistically significant differences in survival, but a quadratic model provided a good fit to the relation between survival and discharge. Further studies of this type, despite being conducted using surface acclimated fish released through hoses, could be used to determine if there is a consistent relation between survival and turbine operation within turbine families (turbines of similar design) or at different dams. This level of information is needed if turbines are to be operated to achieve the greatest fish survival, as Skalski and others (2002a) recommend.

In summary, our results indicate that few operational covariates were supported as factors affecting turbine passage survival of juvenile salmonids at McNary or John Day dams. Support for linear or quadratic effects of head or turbine unit discharge was not common. Potential reasons the operational factors were generally not supported include the uncontrolled nature of the experiments and the small effect sizes common to even carefully controlled experiments of turbine discharge. Tag burden and water temperature were well-supported factors affecting the survival of juvenile salmonids passing turbines at these dams, and generally corroborate results of other field and laboratory studies. The results suggest tag burden should be minimized in studies of turbine passage, or that factor should be included as an explanatory variable in analyses. Additionally, effects of water temperature on survival were supported in several 
analyses suggesting it should be considered in designs or analyses of studies. The design of existing turbines at McNary Dam is unique to the Columbia River Basin, but those at John Day are similar to turbines at three of the four lower Snake River dams (Wittinger and others, 2010). This study identified several factors affecting the survival of fish passing turbines, but it is the only study we know of that examined data from tagged fish volitionally passing through turbines for this purpose. It may be prudent to examine similar data from past studies at other FCRPS dams to corroborate these results.

\section{Acknowledgments}

This work was made possible by a suite of people and organizations responsible for the design, conduct, reporting, and funding of the studies that collected the data we used in analyses. These include staff at the U.S. Geological Survey (USGS), Western Fisheries Research Center office in Cook, Washington, National Oceanic and Atmospheric Administration (NOAA), Northwest Fisheries Science Center office in Pasco, Washington, and the U.S. Army Corps of Engineers, Portland District located in Portland, Oregon, and Walla Walla District located in Walla Walla, Washington. The contracts for this study were overseen by Michael Langeslay, George Medina, and Dennis Schwartz of the Portland District U.S. Army Corps of Engineers. Gordon Axel of NOAA Fisheries and Amy Braatz, Scott Brewer, Scott Evans, Gabriel Hansen of USGS, and Christopher Walker, formerly of USGS, assisted with the compilation of the data sets. Jon Renholds with the Walla Walla District Corps of Engineers provided much of the operations data. Reviews by Paul Heisey, Toby Kock, and staff of the U.S. Army Corps of Engineers improved the document. This work was completed under contract numbers W66QKZ00712046 and W66QKZ00712056.

\section{References Cited}

Adams, N.S., Plumb, J.M., Hatton, T.W., Jones, E.C., Swyers, N.M., Sholtis, M.D., Reagan, R.E., and Cash, K.M., 2008, Survival and migration behavior of juvenile salmonids at McNary Dam, 2006: U.S. Geological Survey report to the U. S. Army Corps of Engineers, Walla Walla District, report number 2006-W68SBV60478899, 150 p.

Adams, N.S. and Counihan, T.D., eds., 2009, Survival and migration behavior of juvenile salmonids at McNary Dam, 2007: U.S. Geological Survey report to the U.S. Army Corps of Engineers, Contract W68SBV70178419, 226 p.

Adams, N.S., and Liedtke, T.L., editors, 2009, Juvenile salmonid survival, passage, and egress at McNary Dam during tests of temporary spillway weirs, 2008: U.S. Geological Survey report to the U.S. Army Corps of Engineers, Walla Walla District, report 2008-W68SBV80448890, $157 \mathrm{p}$.

Adams, N.S., and Liedtke, T.L., editors, 2010, Juvenile salmonid survival, passage, and egress at McNary Dam during tests of temporary spillway weirs, 2009: U S. Geological Survey draft report to the U.S. Army Corps of Engineers, Contract W68SBV90070150, 190 p.

Axel, G.A., Hockersmith, E.E., Eppard, M.B., and Sandford, B.P., 2004a, Passage and survival of hatchery yearling Chinook salmon at McNary Dam, 2002: NOAA Fisheries report to the U.S. Army Corps of Engineers, Walla Walla District, Contract W68SBV92844866, 42 p. 
Axel, G.A., Hockersmith, E.E., Eppard, M.B., and Sandford, B.P., 2004b, Passage and survival of hatchery yearling Chinook salmon at McNary Dam, 2003: NOAA Fisheries report to the U.S. Army Corps of Engineers, Walla Walla District, Contract W68SBV92844866, 46 p.

Beeman, J.W., and Maule, A.G., 2006, Migration depths of juvenile Chinook salmon and steelhead relative to total dissolved gas supersaturation in a Columbia River reservoir: Transactions of the American Fisheries Society, v. 135, p. 584-594.

Beeman, J.W., Dingmon, L., Juhnke, S., Hansel, H.C., Hausmann, B., and Haner, P., 2006, Estimates of fish, spill, and juvenile fish bypass passage efficiencies of radio-tagged juvenile salmonids relative to spring and summer spill treatments at John Day Dam in 2002: U.S. Geological Survey report to the U.S. Army Corps of Engineers, Portland District, Contract W66QKZ20101683, 75 p.

Beeman, J.W., Braatz, A.C., Hansel, H.C., Fielding, S.D., Haner, P.V., Hansen, G.S., Shurtleff, D.J., Sprando, J.M., and Rondorf, D.W., 2010, Approach, passage, and survival of juvenile salmonids at Little Goose Dam, Washington: Post-construction evaluation of a temporary spillway weir, 2009: U.S. Geological Survey Open-File Report 2010-1224, 100 p.

Belsley, D.A., Kuh, E., and Welsch, R.E., 1980, Regression diagnostics: Identifying influential data and sources of collinearity: New York, John Wiley and Sons, 292 p.

Brown, R.S., Carlson, T.J., Welch, A.E., Stephenson, J.R., Abernethy, C.S., Ebberts, B.D., Langeslay, M.J., Ahmann, M.L., Feil, D.H., Skalski, J.R., and Townsend, R.L., 2009, Assessment of barotrauma from rapid decompression of depth-acclimated juvenile Chinook salmon bearing radiotelemetry transmitters: Transactions of the American Fisheries Society, v. 138, p. 1285-1301.

Burnham, K.P., and Anderson, D.R., 2002, Model selection and multimodel inference: A practical information-theoretic approach: Springer-Verlag, New York, 488 p.

Cada, G.F., 2001, The development of advanced hydroelectric turbines to improve fish passage survival: Fisheries, v. 26, p.14-23.

Cada, G.F., Loar, J., Garrison, L, Fisher, R. Jr., and Neitzel, D., 2006, Efforts to reduce mortality to hydroelectric turbine-passed fish- locating and quantifying damaging shear stresses: Environmental Management, v. 37, no. 6, p. 898-906.

Carlson, T.J., Brown R.S., Stephenson, J.R., Gingerich, A.J., Pflugrath, B.D., Colotelo, A.H., Welch, A.E., Benjamin, P.L., Skalski, J.R., Seaburg, A.G., and Townsend, R.L., 2010, Assessment of barotrauma in untagged and tagged juvenile Chinook salmon exposed to simulated hydro turbine passage: Richland, Washington, Pacific Northwest National Laboratory report PNNL-19625, 79 p.

Cormack, R.M., 1964, Estimates of survival from the sighting of marked animals: Biometrika, v. 51, p. 429-438.

Counihan, T.D., Holmberg, G.S., and Petersen, J.H., 2006a, Survival estimates of migrant juvenile salmonids in the Columbia River through John Day Dam using radio telemetry, 2002: U.S. Geological Survey report to the U.S. Army Corps of Engineers, Portland District, Contract W66QKZ20384546, 117 p.

Counihan, T.D., Holmberg, G.S., Walker, C.E., and Hardiman, J.M., 2006b, Survival estimates of migrant juvenile salmonids in the Columbia River through John Day Dam using radiotelemetry, 2003: U. S. Geological Survey report to the U. S. Army Corps of Engineers, Portland District, Contract W66QKZ31005684, 76 p. 
Devries, J.H., Citta, J.J., Lindberg, M.S., Howerter, D.W., and Anderson, M.G., 2003, Breedingseason survival of mallard females in the prairie pothole region of Canada: Journal of Wildlife Management, v. 67, no. 3, p. 551-563.

Faler, M.P., Miller, L.M., and Welke, K.I., 1988, Effects on variation in flow on distributions of northern squawfish in the Columbia River below McNary Dam: North American Journal of Fisheries Management, v. 8, p. 30-35.

Ferguson, J.W., Absolon, R.F., Carlson, T.J., and Sandford, B.P., 2006, Evidence of delayed mortality on juvenile Pacific salmon passing through turbines at Columbia River dams:

Transactions of the American Fisheries Society, v. 135, p. 139-150.

Fried, S.M., McCleave, J.D., and Stred, K.A., 1976, Buoyancy compensation by Atlantic salmon (Salmo salar) smolts tagged internally with dummy telemetry transmitters: Journal of the Fisheries Research Board of Canada v. 3, p. 377-1380.

Hansel, H.C., Beeman, J.W., Hausmann, B.J., Juhnke, S.D., Haner, P.V., and Phelps, J.P., 2004, Estimates of fish, spill, and juvenile fish bypass passage efficiencies of radio-tagged juvenile salmonids relative to spring and summer spill treatments at John Day Dam in 2003: U. S. Geological Survey report to the U. S. Army Corps of Engineers, Portland District, 83 p.

Heisey, P.G., Mathur, D., and Rineer, T., 1992, A reliable tag-recapture technique for estimating turbine-passage survival: application to young-of-the-year American shad (Alosa sapidissima): Canadian Journal of Fisheries and Aquatic Sciences, v. 49, p. 1,826-1,834.

Johnson, G.E., Anglea, S.M., Adams, N.S., and Wik, T.O., 2005, Evaluation of the prototype surface flow bypass for juvenile salmon and steelhead at the powerhouse of Lower Granite Dam, Snake River, Washington 1996-2000: North American Journal of Fisheries Management, v. 25, p. 138-151.

Jolly, G.M., 1965, Explicit estimates from capture-recapture data with both death and immigration-stochastic model: Biometrika, v. 52, p. 225-247.

Keefer, M.L., Peery, C.A., Bjornn, T.C., Jepson, M.A., and Stuehrenberg, L.C., 2004, Hydrosystem, dam, and reservoir passage rates of adult Chinook salmon and steelhead in the Columbia and Snake rivers: Transactions of the American Fisheries Society, v. 133, p. 1,4131,439 .

Mathur, D., Heisey, P.G., Euston, E.T., Skalski, J.R., and Hayes, S., 1996, Turbine passage survival estimation for Chinook salmon smolts (Oncorhynchus tshawytscha) at a large dam on the Columbia River: Canadian Journal of Fisheries and Aquatic Sciences, v. 53, p. 542-549.

Mathur, D., P.G. Heisey, J.R. Skalski, and Kenney, D.R., 2000, Salmonid smolt survival relative to turbine efficiency and entrainment depth in hydroelectric power generation: Journal of the American Water Resources Association, v. 36, no. 4, p. 737-747.

Mesa, M.M., Poe, T.P., Gadomski, D.M., and Petersen, J.H., 1994, Are all prey created equal? A review and synthesis of differential predation on prey in substandard condition: Journal of Fish Biology, v. 45, supp. A, p. 81-96.

Muir, W.D., Smith, S.G., Williams, J.G., and Sandford, B.P., 2001, Survival of juvenile salmonids passing through bypass systems, turbines, and spillways with and without flow deflectors at Snake River dams: North American Journal of Fisheries Management, v. 21, p. $135-146$.

National Oceanic and Atmospheric Administration's National Marine Fisheries Service, 2008, Endangered species cat section 7(a)(2) consultation biological opinion and Magnuson-Stevens Fishery Conservation and Management Act essential fish habitat consultation: National Oceanic and Atmospheric Administration, log number F/NWR/2005/05883. 
National Research Council, 1996, Upstream-salmon and society in the Pacific Northwest: Washington, D.C., National Academy Press, 452 p.

Normandeau Associates, Skalski, J.R., and Mid Columbia Consulting, 1996, Fish survival investigation relative to turbine rehabilitation at Wanapum Dam, Columbia River, Washington: Normandeau Associates, Inc., Report for Grant County Public Utility District Number 2, Ephrata, Washington.

Normandeau Associates, Skalski, J.R., and Mid Columbia Consulting, 2003, Survival/condition of Chinook salmon smolts under different turbine operations at McNary Dam, Columbia River: Report to U.S. Army Corps of Engineers, Contract DACW68-02-D-0002 Task Order 1, $124 \mathrm{p}$.

Normandeau Associates, Skalski, J.R., and Townsend, R.L., 2008a, Turbine operational effects on survival/condition of yearling Chinook salmon (Oncorhynchus tshawytscha), at Ice Harbor Dam, March 2007: Report to U.S. Army Corps of Engineers, Contract DACW68-02-D-0002 Task Order 29, 125 p.

Normandeau Associates, Skalski, J.R., and Townsend, R., 2008b, Direct survival and injury evaluation of juvenile Chinook salmon passing John Day Dam spillway with and without a top spillway weir (TSW): Report to Battelle PNNL Richland, Washington and U.S. Army Corps of Engineers, Portland, Oregon, 73 p.

Odeh, M., 1999, A summary of environmentally friendly turbine design concepts: U.S. Geological Survey report to U.S. Department of Energy, Contract DE-AI07-9ID13741.

Perry, R.W., Braatz, A.C., Fielding, S.D., Lucchesi, J.N., Plumb, J.M., Adams, N.S., and Rondorf, D.W., 2006, Survival and migration behavior of juvenile salmonids at McNary Dam, 2004: U.S. Geological Survey report to the U.S. Army Corps of Engineers, Walla Walla District, Contract W68SBV40271050, 155 p.

Perry, R.W., Braatz, A.C., Novick, M.S., Lucchesi, J.L., Rutz, G.L., Koch, R.C., Schei, J.S., Adams, N.S., and Rondorf, D.W., 2007, Survival and migration behavior of juvenile salmonids at McNary Dam, 2005: U.S. Geological Survey report to the U.S. Army Corps of Engineers, Walla Walla District, Contract W68SBV50407617, 188 p.

Petersen, J.H., 1994, Importance of spatial pattern in estimating predation of juvenile salmonids in the Columbia River: Transactions of the American Fisheries Society, v. 13, p. 924-930.

Pollock, K.H., 2002, The use of auxiliary variables in capture-recapture modeling-an overview: Journal of Applied Statistics, v. 29, nos. 1-4, p. 85-102.

Rieman, B.E., Beamesderfer, R.C., Vigg, S., and Poe, T.P., 1991, Estimated loss of juvenile salmonids to predation by northern squawfish, walleyes, and smallmouth bass in John Day reservoir, Columbia River: Transactions of the American Fisheries Society, v. 120, p. 448458.

Ryan, B.A., Ferguson, J.W., Ledgerwood, R.D., and Nunnallee, E.P., 2001, Detection of passive integrated transponder tags from juvenile salmonids on piscivorous bird colonies in the Columbia River Basin: North American Journal of Fisheries Management, v. 21, p. 417-421.

Seber, G.A.F., 1965, A note on the multiple recapture census: Biometrika, v. 52, p. 249-259.

Skalski, J.R., Mathur, D., and Heisey, P.G., 2002a, Effects of turbine operating efficiency on smolt passage survival: North American Journal of Fisheries Management, v. 22, p. 1193-1200. 
Skalski, J.R., Townsend, R., Lady, J., Giorgi, A.E., Stevenson, J.R., and McDonald, R.S., 2002b, Estimating route-specific passage and survival probabilities at a hydroelectric project from smolt radiotelemetry studies: Canadian Journal of Fisheries and Aquatic Sciences, v. 59, p. $1,385-1,393$.

Swan, G.A., Eppard., M.B., Hockersmith, E. E., Sandford, B.P., Iverson, B.L., Ocker, P. A., Kaminski, M.A., and Iwamoto, R.N., 1997, Juvenile ratio-telemetry study at Ice Harbor Dam, 1995: Report by National Marine Fisheries Service to U.S. Army Corps of Engineers, Contract E86-95-0113, $39 \mathrm{p}$.

Ward, D.L., Petersen, J.H., and Loch, J.J., 1995, Index of predation on juvenile salmonids by northern squawfish in the lower and middle Columbia River and in the lower Snake River: Transactions of the American Fisheries Society, v. 124, p. 321-334.

White, G.C., 2002, Discussion comments on-the use of auxiliary variables in capture-recapture modeling. An overview: Journal of Applied Statistics, v. 29, nos. 1-4, p. 103-106.

White, G.C., and Burnham, K.P., 1999, Program MARK-survival estimation from populations of markeed animals: Bird Study, v. 46 (supp.), p. 120-138.

Williams, J.G., Smith, S.G., and Muir, W.D., 2001, Survival estimates of downstream migrant yearling juvenile salmonids through the Snake and Columbia rivers hydropower system, 19661980 and 1993-1999: North American Journal of Fisheries Management, v. 21, p. 310-317.

Wittinger, R.J., Sollars, R., and Hsieh, C., 2010, Columbia and Snake river turbines stay vane and wicket gate geometry study: Report by the U.S. Army Corps of Engineers Hydroelectric Design Center, Northwestern Division, Portland District, 153 p. 


\section{Appendix A. Summaries of Covariate Values from Data used in Studies of Yearling Chinook Salmon at John Day Dam in 2002 and 2003.}

Table A1 - Summary statistics of turbine unit discharge (thousand ft3/s) during yearling Chinook salmon passage from data used in studies at John Day Dam in 2002 and 2003.

$[N$, number of observations; Min, minimum; Max, maximum; SD, standard deviation; SE, standard error]

\begin{tabular}{lcccccccc}
\hline & Year & $\boldsymbol{N}$ & Min & Max & Mean & Median & SD & SE \\
\hline Overall & 2002 & 120 & 11.90 & 22.10 & 15.33 & 15.00 & 2.33 & 0.21 \\
& 2003 & 126 & 11.40 & 22.20 & 15.48 & 15.10 & 2.86 & 0.25 \\
& Overall & 246 & 11.40 & 22.20 & 15.41 & 15.05 & 2.61 & 0.17 \\
\hline Day & 2002 & 46 & 12.30 & 22.10 & 16.66 & 15.85 & 2.73 & 0.40 \\
& 2003 & 59 & 11.50 & 22.20 & 17.52 & 17.00 & 2.70 & 0.35 \\
\hline Night & 2002 & 74 & 11.90 & 18.30 & 14.51 & 14.60 & 1.57 & 0.18 \\
& 2003 & 67 & 11.40 & 17.30 & 13.69 & 13.30 & 1.44 & 0.18 \\
\hline
\end{tabular}

Table A2 - Summary statistics of head (feet) at John Day Dam during yearling Chinook salmon passage from data used in studies at John Day Dam in 2002 and 2003.

$[N$, number of observations; Min, minimum; Max, maximum; SD, standard deviation; SE, standard error $]$

\begin{tabular}{lcccccccc}
\hline & Year & $\boldsymbol{N}$ & Min & Max & Mean & Median & SD & SE \\
\hline Overall & 2002 & 120 & 98.00 & 104.10 & 101.61 & 101.60 & 1.19 & 0.11 \\
& 2003 & 126 & 97.00 & 104.49 & 101.27 & 101.53 & 1.64 & 0.15 \\
& Overall & 246 & 97.00 & 104.49 & 101.44 & 101.57 & 1.44 & 0.09 \\
\hline Day & 2002 & 46 & 98.00 & 103.50 & 101.32 & 101.50 & 1.31 & 0.19 \\
& 2003 & 59 & 97.00 & 102.61 & 100.34 & 100.50 & 1.53 & 0.20 \\
\hline Night & 2002 & 74 & 99.50 & 104.10 & 101.79 & 101.80 & 1.08 & 0.13 \\
& 2003 & 67 & 99.11 & 104.49 & 102.09 & 102.12 & 1.26 & 0.15 \\
\hline
\end{tabular}

Table A3 - Summary statistics of total project discharge (thousand $\mathrm{ft}^{3} / \mathrm{s}$ ) during yearling Chinook salmon passage from data used in studies at John Day Dam in 2002 and 2003.

[N, number of observations; Min, minimum; Max, maximum; SD, standard deviation; SE, standard error]

\begin{tabular}{lcccccccc}
\hline & Year & $\boldsymbol{N}$ & Min & Max & Mean & Median & SD & SE \\
\hline Overall & 2002 & 871 & 150.30 & 318.20 & 226.96 & 228.00 & 38.94 & 1.32 \\
& 2003 & 2102 & 138.90 & 372.40 & 230.75 & 226.50 & 50.24 & 1.10 \\
& Overall & 2973 & 138.90 & 372.40 & 229.64 & 227.70 & 47.24 & 0.87 \\
\hline Day & 2002 & 301 & 160.10 & 316.50 & 215.81 & 217.50 & 43.02 & 2.48 \\
& 2003 & 540 & 166.20 & 372.40 & 238.46 & 221.20 & 52.50 & 2.26 \\
\hline Night & 2002 & 570 & 150.30 & 318.20 & 232.85 & 234.00 & 35.24 & 1.48 \\
& 2003 & 1562 & 138.90 & 344.30 & 228.08 & 226.90 & 49.18 & 1.24 \\
\hline
\end{tabular}


Table A4 - Summary statistics of spill percentage during yearling Chinook salmon passage from data used in studies at John Day Dam in 2002 and 2003.

$[N$, number of observations; Min, minimum; Max, maximum; SD, standard deviation; SE, standard error $]$

\begin{tabular}{llrllrrrr}
\hline & Year & \multicolumn{1}{c}{$\boldsymbol{N}$} & Min & Max & Mean & Median & \multicolumn{1}{c}{ SD } & SE \\
\hline Overall & 2002 & 991 & 0.00 & 61.67 & 33.08 & 30.13 & 19.03 & 0.60 \\
& 2003 & 2228 & 0.00 & 73.69 & 39.15 & 46.13 & 23.98 & 0.51 \\
& Overall & 3219 & 0.00 & 73.69 & 37.28 & 45.54 & 22.74 & 0.40 \\
\hline Day & 2002 & 347 & 0.00 & 43.12 & 15.83 & 18.89 & 14.47 & 0.78 \\
& 2003 & 599 & 0.00 & 48.25 & 1.13 & 0.00 & 4.56 & 0.19 \\
\hline Night & 2002 & 644 & 26.12 & 61.67 & 42.37 & 31.34 & 14.06 & 0.55 \\
& 2003 & 1629 & 43.88 & 73.69 & 53.13 & 54.17 & 7.19 & 0.18 \\
\hline
\end{tabular}

Table A5 - Summary statistics of tag burden (percent) of yearling Chinook salmon from data used in studies at John Day Dam in 2002 and 2003.

[ $N$, number of observations; Min, minimum; Max, maximum; SD, standard deviation; SE, standard error]

\begin{tabular}{lrrlccccc}
\hline & & $\boldsymbol{N}$ & Min & Max & Mean & Median & SD & SE \\
\hline Overall & 2002 & 991 & 1.30 & 8.92 & 4.66 & 4.67 & 1.33 & 0.04 \\
& 2003 & 2228 & 1.23 & 7.78 & 4.42 & 4.46 & 1.28 & 0.03 \\
& Overall & 3219 & 1.23 & 8.92 & 4.49 & 4.53 & 1.30 & 0.02 \\
\hline Day & 2002 & 347 & 2.03 & 8.24 & 4.83 & 4.86 & 1.35 & 0.07 \\
& 2003 & 599 & 1.23 & 7.69 & 4.34 & 4.36 & 1.26 & 0.05 \\
\hline Night & 2002 & 644 & 1.30 & 8.92 & 4.56 & 4.59 & 1.30 & 0.05 \\
& 2003 & 1629 & 1.35 & 7.78 & 4.44 & 4.49 & 1.28 & 0.03 \\
\hline
\end{tabular}

Table A6 - Summary statistics of temperature during yearling Chinook salmon passage from data used in studies at John Day Dam in 2002 and 2003.

[N, number of observations; Min, minimum; Max, maximum; SD, standard deviation; SE, standard error]

\begin{tabular}{lccrccccc}
\hline & Year & \multicolumn{1}{c}{$\boldsymbol{N}$} & Min & Max & Mean & Median & SD & SE \\
\hline Overall & 2002 & 991 & 9.70 & 14.30 & 11.88 & 11.80 & 1.38 & 0.04 \\
& 2003 & 2228 & 10.56 & 15.44 & 12.56 & 12.17 & 1.40 & 0.03 \\
& Overall & 3219 & 9.70 & 15.44 & 12.35 & 12.17 & 1.43 & 0.03 \\
\hline Day & 2002 & 347 & 9.90 & 14.10 & 11.76 & 11.80 & 1.36 & 0.07 \\
& 2003 & 599 & 10.56 & 15.22 & 12.59 & 12.17 & 1.41 & 0.06 \\
\hline Night & 2002 & 644 & 9.70 & 14.30 & 11.94 & 12.20 & 1.40 & 0.06 \\
& 2003 & 1629 & 10.61 & 15.44 & 12.55 & 12.17 & 1.40 & 0.03 \\
\hline
\end{tabular}




\section{Appendix B. Capture History Summary of Yearling Chinook Salmon from data used in studies at John Day Dam in 2002 and 2003.}

[Occ. represents the Occasion number after release. $R(i)$ represents numbers released and $\mathrm{j}=2$ and 3 indicate the released number detected at each downstream site]

\begin{tabular}{ccccc}
\hline \multicolumn{5}{c}{ Group 1 control day 2002} \\
Occ. & R(i) & $\mathrm{j}=2$ & $\mathrm{j}=3$ & Total \\
\hline 1 & 301 & 208 & 79 & 287 \\
2 & 208 & & 203 & 203
\end{tabular}

Group 2 control day 2003

\begin{tabular}{ccccc} 
Occ. & $\mathrm{R}(\mathrm{i})$ & $\mathrm{j}=2$ & $\mathrm{j}=3$ & Total \\
\hline 1 & 540 & 401 & 127 & 528 \\
2 & 401 & & 398 & 398
\end{tabular}

Group 3 control night 2002

\begin{tabular}{|c|c|c|c|c|}
\hline Occ. & $\mathrm{R}(\mathrm{i})$ & $\mathrm{j}=2$ & $j=3$ & Total \\
\hline 1 & 570 & 366 & 174 & 540 \\
\hline 2 & 366 & & 349 & 349 \\
\hline
\end{tabular}

Group 4 control night 2003

\begin{tabular}{ccccc} 
Occ. & $\mathrm{R}(\mathrm{i})$ & $\mathrm{j}=2$ & $\mathrm{j}=3$ & Total \\
\hline 1 & 1562 & 1332 & 195 & 1527 \\
2 & 1332 & & 1304 & 1304
\end{tabular}

Group 5 turbine day 2002

\begin{tabular}{|c|c|c|c|c|}
\hline Occ. & $\mathrm{R}(\mathrm{i})$ & $\mathrm{j}=2$ & $\mathrm{j}=3$ & Total \\
\hline 1 & 46 & 31 & 9 & 40 \\
\hline 2 & 31 & & 30 & 30 \\
\hline
\end{tabular}

Group 6 turbine day 2003

\begin{tabular}{ccccc} 
Occ. & $\mathrm{R}(\mathrm{i})$ & $\mathrm{j}=2$ & $\mathrm{j}=3$ & Total \\
\hline 1 & 59 & 38 & 12 & 50 \\
2 & 38 & & 38 & 38
\end{tabular}

Group 7 turbine night 2002

\begin{tabular}{|c|c|c|c|c|}
\hline Occ. & $\mathrm{R}(\mathrm{i})$ & $\mathrm{j}=2$ & $\mathrm{j}=3$ & Total \\
\hline 1 & 74 & 47 & 19 & 66 \\
\hline 2 & 47 & & 46 & 46 \\
\hline
\end{tabular}

Group 8 turbine night 2003

\begin{tabular}{|c|c|c|c|c|}
\hline Occ. & $\mathrm{R}(\mathrm{i})$ & $\mathrm{j}=2$ & $\mathrm{j}=3$ & Total \\
\hline 1 & 67 & 53 & 10 & 63 \\
\hline 2 & 53 & & 53 & 53 \\
\hline
\end{tabular}




\section{Appendix C. Model Summary from Analyses of Recapture Probabilities ( $p$ ) of Yearling Chinook Salmon from data used in studies at John Day Dam in 2002 and 2003.}

[Models of $\mathrm{p}$ include those in which values can vary in various combinations of detection site ( $\mathrm{t}$ ) and group (treatment, year, and photoperiod). A ' ${ }^{\prime}$ ' indicated a multiplicative effect, a '+' indicates an additive effect, and a '.' indicates a common value fitted to all groups and reaches. A multiplicative model ( $\mathrm{g} * \mathrm{t})$ of apparent survival (phi) was used in all models. $\mathrm{K}$ indicates the number of estimable parameters]

\begin{tabular}{lcccccc}
\hline \multicolumn{1}{c}{ Model } & AICc & $\begin{array}{c}\text { Delta } \\
\text { AlCc }\end{array}$ & $\begin{array}{c}\text { AlCc } \\
\text { Weights }\end{array}$ & $\begin{array}{c}\text { Model } \\
\text { Likelihood }\end{array}$ & K & Deviance \\
\hline$\{01$ phi $(\mathrm{g} * \mathrm{t}), \mathrm{p}(\mathrm{g} * \mathrm{t})\}$ & 4521.89 & 0.00 & 1.00 & 1.00 & 24 & 4473.67 \\
$\{02$ phi $(\mathrm{g} * \mathrm{t}), \mathrm{p}(\mathrm{g}+\mathrm{t})\}$ & 4536.05 & 14.17 & 0.00 & 0.00 & 24 & 4487.84 \\
$\{03$ phi $(\mathrm{g} * \mathrm{t}), \mathrm{p}(\mathrm{g}\}$ & 5069.96 & 548.07 & 0.00 & 0.00 & 24 & 5021.75 \\
$\{04$ phi $(\mathrm{g} * \mathrm{t}), \mathrm{p}(\mathrm{t})\}$ & 4639.80 & 117.92 & 0.00 & 0.00 & 17 & 4605.69 \\
$\{05$ phi $(\mathrm{g} * \mathrm{t}), \mathrm{p}()\}$. & 5178.08 & 656.20 & 0.00 & 0.00 & 17 & 5143.97 \\
\hline
\end{tabular}




\section{Appendix D. Summaries of Covariate Values of Subyearling Chinook Salmon from data used in studies at John Day Dam in 2002 and 2003.}

Table D1 - Summary statistics of turbine unit discharge (thousand $\mathrm{ft} 3 / \mathrm{s}$ ) during subyearling Chinook salmon passage from data used in studies at John Day Dam in 2002 and 2003.

[ $N$, number of observations; Min, minimum; Max, maximum; SD, standard deviation; SE, standard error]

\begin{tabular}{lcccccccc}
\hline & Year & $\boldsymbol{N}$ & $\boldsymbol{M i n}$ & Max & Mean & Median & SD & SE \\
\hline Overall & 2002 & 249 & 11.90 & 22.70 & 15.64 & 15.20 & 2.75 & 0.17 \\
& 2003 & 547 & 9.70 & 20.90 & 14.58 & 14.40 & 1.72 & 0.07 \\
& Overall & 796 & 9.70 & 22.70 & 14.91 & 14.70 & 2.15 & 0.08 \\
\hline Day & 2002 & 115 & 12.00 & 22.70 & 17.13 & 16.50 & 3.04 & 0.28 \\
& 2003 & 318 & 9.70 & 20.90 & 15.07 & 15.00 & 1.63 & 0.09 \\
\hline Night & 2002 & 134 & 11.90 & 18.70 & 14.36 & 13.70 & 1.62 & 0.14 \\
& 2003 & 229 & 10.70 & 19.80 & 13.89 & 13.50 & 1.59 & 0.11 \\
\hline
\end{tabular}

Table D2 - Summary statistics of head (feet) during subyearling Chinook salmon passage from data used in studies at John Day Dam in 2002 and 2003.

[ $N$, number of observations; Min, minimum; Max, maximum; SD, standard deviation; SE, standard error ]

\begin{tabular}{lcccccccc}
\hline & Year & $\boldsymbol{N}$ & Min & Max & Mean & Median & SD & SE \\
\hline Overall & 2002 & 249 & 97.00 & 104.00 & 100.61 & 100.40 & 1.33 & 0.08 \\
& 2003 & 547 & 99.50 & 105.65 & 103.12 & 103.18 & 0.91 & 0.04 \\
& Overall & 796 & 97.00 & 105.65 & 102.34 & 102.70 & 1.57 & 0.06 \\
\hline Day & 2002 & 115 & 97.00 & 103.80 & 100.26 & 100.30 & 1.47 & 0.14 \\
& 2003 & 318 & 99.50 & 105.31 & 102.89 & 102.91 & 0.93 & 0.05 \\
\hline \multirow{2}{*}{ Night } & 2002 & 134 & 98.30 & 104.00 & 100.92 & 100.90 & 1.13 & 0.10 \\
& 2003 & 229 & 100.58 & 105.65 & 103.43 & 103.41 & 0.79 & 0.05 \\
\hline
\end{tabular}

Table D3 - Summary statistics of total project discharge (thousand $\mathrm{ft} 3 / \mathrm{s}$ ) during subyearling Chinook salmon passage from data used in studies at John Day Dam in 2002 and 2003.

[ $N$, number of observations; Min, minimum; Max, maximum; SD, standard deviation; SE, standard error]

\begin{tabular}{lccrccccc}
\hline & Year & $\boldsymbol{N}$ & $\boldsymbol{M i n}$ & Max & Mean & Median & SD & SE \\
\hline Overall & 2002 & 2649 & 157.70 & 396.20 & 264.62 & 253.90 & 54.19 & 1.05 \\
& 2003 & 2814 & 89.90 & 237.40 & 153.77 & 152.20 & 33.12 & 0.62 \\
& Overall & 5463 & 89.90 & 396.20 & 207.52 & 194.70 & 71.12 & 0.96 \\
\hline Day & 2002 & 1150 & 182.90 & 396.20 & 282.45 & 269.40 & 51.44 & 1.52 \\
& 2003 & 1392 & 89.90 & 230.60 & 157.52 & 156.00 & 36.69 & 0.98 \\
\hline Night & 2002 & 1499 & 157.70 & 369.40 & 250.93 & 252.10 & 52.24 & 1.35 \\
& 2003 & 1422 & 90.80 & 237.40 & 150.11 & 146.80 & 28.77 & 0.76 \\
\hline
\end{tabular}


Table D4 - Summary statistics of spill percentage during subyearling Chinook salmon passage from data used in studies at John Day Dam in 2002 and 2003.

[ $N$, number of observations; Min, minimum; Max, maximum; SD, standard deviation; SE, standard error ]

\begin{tabular}{lcccccccc}
\hline & Year & $\boldsymbol{N}$ & Min & Max & Mean & Median & SD & SE \\
\hline Overall & 2002 & 2898 & 0.00 & 67.93 & 33.18 & 30.36 & 17.51 & 0.33 \\
& 2003 & 3361 & 0.00 & 64.87 & 28.66 & 29.80 & 21.04 & 0.36 \\
& Overall & 6259 & 0.00 & 67.93 & 30.76 & 29.93 & 19.61 & 0.25 \\
\hline Day & 2002 & 1265 & 0.00 & 61.21 & 21.13 & 28.54 & 14.54 & 0.41 \\
& 2003 & 1710 & 0.00 & 61.03 & 14.28 & 0.00 & 14.92 & 0.36 \\
\hline \multirow{2}{*}{ Night } & 2002 & 1633 & 27.28 & 67.93 & 42.52 & 33.08 & 13.45 & 0.33 \\
& 2003 & 1651 & 0.00 & 64.87 & 43.56 & 31.74 & 15.30 & 0.38 \\
\hline
\end{tabular}

Table D5 - Summary statistics of tag burden (percent) of subyearling Chinook salmon from data used in studies at John Day Dam in 2002 and 2003.

[ $N$, number of observations; Min, minimum; Max, maximum; SD, standard deviation; SE, standard error ]

\begin{tabular}{lcccccccc}
\hline & Year & $\boldsymbol{N}$ & Min & Max & Mean & Median & SD & SE \\
\hline Overall & 2002 & 2898 & 1.67 & 7.33 & 5.13 & 5.28 & 0.81 & 0.01 \\
& 2003 & 3361 & 2.24 & 7.20 & 5.31 & 5.45 & 0.78 & 0.01 \\
& Overall & 6259 & 1.67 & 7.33 & 5.22 & 5.35 & 0.80 & 0.01 \\
\hline \multirow{2}{*}{ Day } & 2002 & 1265 & 1.95 & 7.33 & 5.13 & 5.28 & 0.82 & 0.02 \\
& 2003 & 1710 & 2.24 & 6.54 & 5.30 & 5.45 & 0.78 & 0.02 \\
\hline \multirow{2}{*}{ Night } & 2002 & 1633 & 1.67 & 6.75 & 5.13 & 5.28 & 0.79 & 0.02 \\
& 2003 & 1651 & 2.28 & 7.20 & 5.31 & 5.41 & 0.78 & 0.02 \\
\hline
\end{tabular}

Table D6 - Summary statistics of temperature during subyearling Chinook salmon passage from data used in studies at John Day Dam in 2002 and 2003.

[ $N$, number of observations; Min, minimum; Max, maximum; SD, standard deviation; SE, standard error]

\begin{tabular}{lcccccccc}
\hline & Year & $\boldsymbol{N}$ & Min & Max & Mean & Median & SD & SE \\
\hline Overall & 2002 & 2898 & 15.90 & 20.30 & 17.82 & 17.60 & 1.18 & 0.02 \\
& 2003 & 3361 & 16.33 & 21.61 & 18.74 & 18.44 & 1.43 & 0.02 \\
& Overall & 6259 & 15.90 & 21.61 & 18.31 & 18.00 & 1.40 & 0.02 \\
\hline \multirow{2}{*}{ Day } & 2002 & 1265 & 16.20 & 20.30 & 17.97 & 17.60 & 1.13 & 0.03 \\
& 2003 & 1710 & 16.33 & 20.89 & 18.69 & 18.44 & 1.40 & 0.03 \\
\hline \multirow{2}{*}{ Night } & 2002 & 1633 & 15.90 & 20.30 & 17.69 & 17.40 & 1.21 & 0.03 \\
& 2003 & 1651 & 16.33 & 21.61 & 18.79 & 18.61 & 1.45 & 0.04 \\
\hline
\end{tabular}




\section{Appendix E. Capture History Summary of Subyearling Chinook Salmon from data used in studies at John Day Dam in 2002 and 2003.}

[Occ. represents the Occasion number after release. $R(i)$ represents numbers released and $\mathrm{j}=2$ and 3 indicate the released number detected at each downstream site]

\begin{tabular}{ccccc}
\hline \multicolumn{5}{c}{ Group 1 control day 2002 } \\
Occ. & $\mathrm{R}(\mathrm{i})$ & $\mathrm{j}=2$ & $\mathrm{j}=3$ & Total \\
\hline 1 & 1150 & 504 & 565 & 1069 \\
2 & 504 & & 496 & 496
\end{tabular}

Group 2 control day 2003

\begin{tabular}{ccccc} 
Occ. & $\mathrm{R}(\mathrm{i})$ & $\mathrm{j}=2$ & $\mathrm{j}=3$ & Total \\
\hline 1 & 1392 & 1122 & 255 & 1377 \\
2 & 1122 & & 1114 & 1114
\end{tabular}

Group 3 control night 2002

\begin{tabular}{ccccc} 
Occ. & $\mathrm{R}(\mathrm{i})$ & $\mathrm{j}=2$ & $\mathrm{j}=3$ & Total \\
\hline 1 & 1499 & 919 & 499 & 1418 \\
2 & 919 & & 890 & 890
\end{tabular}

Group 4 control night 2003

\begin{tabular}{ccccc} 
Occ. & $\mathrm{R}(\mathrm{i})$ & $\mathrm{j}=2$ & $\mathrm{j}=3$ & Total \\
\hline 1 & 1422 & 1328 & 75 & 1403 \\
2 & 1328 & & 1259 & 1259
\end{tabular}

Group 5 turbine day 2002

\begin{tabular}{ccccc} 
Occ. & R(i) & $\mathrm{j}=2$ & $\mathrm{j}=3$ & Total \\
\hline 1 & 115 & 66 & 36 & 102 \\
2 & 66 & & 64 & 64
\end{tabular}

Group 6 turbine day 2003

\begin{tabular}{ccccc} 
Occ. & $R(i)$ & $j=2$ & $j=3$ & Total \\
\hline 1 & 318 & 223 & 49 & 272 \\
2 & 223 & & 217 & 217
\end{tabular}

Group 7 turbine night 2002

\begin{tabular}{ccccc} 
Occ. & R(i) & $\mathrm{j}=2$ & $\mathrm{j}=3$ & Total \\
\hline 1 & 134 & 96 & 26 & 122 \\
2 & 96 & & 93 & 93
\end{tabular}

Group 8 turbine night 2003

\begin{tabular}{ccccc} 
Occ. & R(i) & $\mathrm{j}=2$ & $\mathrm{j}=3$ & Total \\
\hline 1 & 229 & 183 & 8 & 191 \\
2 & 183 & & 179 & 179 \\
\hline
\end{tabular}




\section{Appendix F. Model Summary from Analyses of Recapture Probabilities ( $p$ ) of Subyearling Chinook Salmon from data used in studies at John Day Dam in 2002 and 2003.}

[Models of $\mathrm{p}$ include those in which values can vary in various combinations of detection site (t) and group (treatment, year, and photoperiod). A '*' indicated a multiplicative effect, a '+' indicates an additive effect, and a '.' indicates a common value fitted to all groups and reaches. A multiplicative model ( $\mathrm{g} * \mathrm{t}$ ) of apparent survival (phi) was used in all models. $\mathrm{K}$ indicates the number of estimable parameters]

\begin{tabular}{|c|c|c|c|c|c|c|}
\hline Model & AlCc & $\begin{array}{l}\text { Delta } \\
\text { AICc }\end{array}$ & $\begin{array}{c}\text { AlCc } \\
\text { Weights }\end{array}$ & $\begin{array}{c}\text { Model } \\
\text { Likelihood }\end{array}$ & $\mathrm{K}$ & Deviance \\
\hline$\{1 \operatorname{phi}(g * t), p(g * t)\}$ & 9182.65 & 0.00 & 0.50 & 1.00 & 24 & 9134.54 \\
\hline$\{2 \operatorname{phi}(g * t), p(g+t)\}$ & 9182.65 & 0.00 & 0.50 & 1.00 & 24 & 9134.54 \\
\hline$\{3$ phi $(\mathrm{g} * \mathrm{t}), \mathrm{p}(\mathrm{t})\}$ & 10092.45 & 909.80 & 0.00 & 0.00 & 17 & 10058.39 \\
\hline$\left\{4\right.$ phi $\left(g^{*} t\right), p(g\}$ & 10828.06 & 1645.41 & 0.00 & 0.00 & 24 & 10779.94 \\
\hline$\{5$ phi $(\mathrm{g} * \mathrm{t}), \mathrm{p}()\}$. & 11560.39 & 2377.74 & 0.00 & 0.00 & 17 & 11526.34 \\
\hline
\end{tabular}




\section{Appendix G. Summaries of Covariate Values from Yearling Chinook Salmon from data used in studies at McNary Dam from 2002-2009.}

Table G1 - Summary statistics of turbine unit discharge (thousand $\mathrm{ft} / \mathrm{s}$ ) during yearling Chinook salmon passage from data used in studies at McNary Dam in 2002-2009.

[ $N$, number of observations; Min, minimum; Max, maximum; SD, standard deviation; SE, standard error]

\begin{tabular}{ccrcccccc}
\hline & Year & \multicolumn{1}{c}{$\boldsymbol{N}$} & Min & Max & Mean & Median & SD & SE \\
\hline Overall & 2002 & 33 & 7.93 & 16.40 & 11.12 & 11.48 & 1.46 & 0.25 \\
& 2003 & 95 & 8.14 & 17.27 & 11.85 & 12.07 & 1.01 & 0.10 \\
& 2004 & 173 & 7.90 & 17.10 & 12.54 & 12.10 & 1.65 & 0.13 \\
& 2005 & 287 & 7.80 & 16.30 & 11.15 & 11.80 & 1.51 & 0.09 \\
& 2006 & 213 & 7.99 & 13.11 & 12.13 & 12.15 & 0.56 & 0.04 \\
& 2007 & 273 & 8.41 & 12.46 & 10.77 & 10.82 & 1.14 & 0.07 \\
& 2008 & 163 & 8.12 & 12.42 & 10.37 & 10.21 & 1.34 & 0.10 \\
& 2009 & 182 & 7.83 & 12.43 & 11.34 & 12.01 & 1.14 & 0.08 \\
\hline \multirow{5}{*}{ Day } & Overall & 1419 & 7.80 & 17.27 & 11.38 & 11.90 & 1.43 & 0.04 \\
& 2002 & 12 & 8.67 & 11.86 & 10.73 & 11.51 & 1.21 & 0.35 \\
& 2003 & 14 & 8.71 & 12.34 & 11.33 & 12.06 & 1.23 & 0.33 \\
& 2004 & 32 & 7.90 & 16.60 & 12.56 & 12.05 & 1.96 & 0.35 \\
& 2005 & 98 & 7.90 & 16.30 & 10.48 & 10.05 & 1.77 & 0.18 \\
& 2006 & 107 & 8.71 & 12.94 & 12.19 & 12.21 & 0.59 & 0.06 \\
& 2007 & 55 & 8.41 & 12.31 & 10.39 & 10.09 & 1.10 & 0.15 \\
& 2008 & 56 & 8.12 & 12.42 & 10.57 & 10.31 & 1.41 & 0.19 \\
& 2009 & 67 & 7.83 & 12.36 & 11.30 & 12.04 & 1.26 & 0.15 \\
\hline \multirow{5}{*}{ Night } & 2002 & 21 & 7.93 & 16.40 & 11.35 & 11.37 & 1.57 & 0.34 \\
& 2003 & 81 & 8.14 & 17.27 & 11.94 & 12.07 & 0.95 & 0.11 \\
& 2004 & 141 & 10.00 & 17.10 & 12.54 & 12.10 & 1.58 & 0.13 \\
& 2005 & 189 & 7.80 & 16.20 & 11.50 & 12.00 & 1.22 & 0.09 \\
& 2006 & 106 & 7.99 & 13.11 & 12.06 & 12.14 & 0.53 & 0.05 \\
& 2007 & 218 & 8.50 & 12.46 & 10.87 & 10.88 & 1.13 & 0.08 \\
& 2008 & 107 & 8.33 & 12.33 & 10.27 & 10.16 & 1.29 & 0.12 \\
& 2009 & 115 & 7.92 & 12.43 & 11.37 & 11.95 & 1.06 & 0.10 \\
\hline
\end{tabular}


Table G2 - Summary statistics of head (feet) during yearling Chinook salmon passage from data used in studies at McNary Dam in 2002-2009.

[ $N$, number of observations; Min, minimum; Max, maximum; SD, standard deviation; SE, standard error ]

\begin{tabular}{ccccccccc}
\hline & Year & \multicolumn{1}{c}{$\boldsymbol{N}$} & Min & Max & Mean & Median & SD & SE \\
\hline Overall & 2002 & 33 & 69.50 & 74.20 & 71.98 & 72.10 & 1.01 & 0.18 \\
& 2003 & 95 & 69.78 & 73.97 & 72.06 & 72.01 & 1.07 & 0.11 \\
& 2004 & 173 & 69.06 & 75.91 & 72.98 & 72.99 & 0.99 & 0.08 \\
& 2005 & 287 & 69.85 & 75.31 & 73.15 & 73.02 & 1.19 & 0.07 \\
& 2006 & 213 & 67.47 & 72.69 & 69.98 & 69.92 & 0.99 & 0.07 \\
& 2007 & 273 & 69.93 & 74.28 & 72.19 & 72.10 & 0.98 & 0.06 \\
& 2008 & 163 & 67.81 & 75.41 & 72.53 & 73.12 & 1.97 & 0.15 \\
& 2009 & 182 & 69.40 & 75.43 & 71.75 & 71.63 & 1.23 & 0.09 \\
& Overall & 1419 & 67.47 & 75.91 & 72.12 & 72.13 & 1.58 & 0.04 \\
\hline \multirow{6}{*}{ Day } & 2002 & 12 & 70.30 & 74.20 & 71.99 & 71.75 & 1.05 & 0.30 \\
& 2003 & 14 & 69.93 & 72.27 & 70.95 & 70.86 & 0.84 & 0.23 \\
& 2004 & 32 & 69.06 & 75.91 & 73.18 & 73.35 & 1.53 & 0.27 \\
& 2005 & 98 & 69.85 & 75.31 & 73.18 & 72.93 & 1.59 & 0.16 \\
& 2006 & 107 & 67.47 & 71.47 & 69.97 & 69.93 & 0.98 & 0.09 \\
& 2007 & 55 & 70.08 & 74.28 & 72.38 & 72.43 & 1.04 & 0.14 \\
& 2008 & 56 & 68.30 & 75.16 & 72.45 & 73.02 & 2.24 & 0.30 \\
& 2009 & 67 & 70.07 & 75.43 & 71.91 & 71.67 & 1.26 & 0.15 \\
\hline \multirow{6}{*}{ Night } & 2002 & 21 & 69.50 & 73.40 & 71.97 & 72.20 & 1.01 & 0.22 \\
& 2003 & 81 & 69.78 & 73.97 & 72.25 & 72.17 & 0.99 & 0.11 \\
& 2004 & 141 & 70.21 & 75.04 & 72.93 & 72.96 & 0.82 & 0.07 \\
& 2005 & 189 & 70.92 & 75.08 & 73.14 & 73.15 & 0.92 & 0.07 \\
& 2006 & 106 & 67.57 & 72.69 & 69.98 & 69.92 & 1.00 & 0.10 \\
& 2007 & 218 & 69.93 & 74.18 & 72.14 & 72.07 & 0.96 & 0.06 \\
& 2008 & 107 & 67.81 & 75.41 & 72.57 & 73.16 & 1.81 & 0.18 \\
& 2009 & 115 & 69.40 & 74.43 & 71.65 & 71.49 & 1.21 & 0.11 \\
\hline 6
\end{tabular}


Table G3 - Summary statistics of total project discharge (thousand $\mathrm{ft} 3 / \mathrm{s}$ ) during yearling Chinook salmon passage from data used in studies at McNary Dam in 2002-2009.

[ $N$, number of observations; Min, minimum; Max, maximum; SD, standard deviation; SE, standard error.

* This variable was only applied to fish of the control group, but there was no control group in 2002 or 2003 . Data summaries for 2002 and 2003 are based on fish of the turbine group, but are not included in the Overall row]

\begin{tabular}{lrrrrlllr}
\hline & Year & \multicolumn{1}{c}{$\boldsymbol{N}$} & \multicolumn{1}{c}{ Min } & Max & Mean & Median & SD & SE \\
\hline Overall & $* 2002$ & 33 & 163.40 & 399.10 & 239.30 & 238.20 & 56.70 & 9.87 \\
& $* 2003$ & 95 & 148.32 & 358.34 & 222.56 & 175.64 & 62.68 & 6.43 \\
& 2004 & 755 & 130.20 & 291.50 & 183.84 & 158.10 & 48.18 & 1.75 \\
& 2005 & 1575 & 90.30 & 358.40 & 215.62 & 228.90 & 52.26 & 1.32 \\
& 2006 & 1213 & 166.68 & 399.28 & 327.24 & 343.69 & 48.58 & 1.39 \\
& 2007 & 1310 & 177.02 & 289.06 & 255.44 & 257.24 & 26.89 & 0.74 \\
& 2008 & 949 & 157.03 & 421.09 & 285.46 & 275.62 & 83.74 & 2.72 \\
& 2009 & 935 & 141.43 & 356.09 & 262.79 & 261.27 & 51.01 & 1.67 \\
& Overall & 6737 & 90.30 & 421.09 & 256.28 & 255.60 & 69.41 & 0.85 \\
\hline Day & $* 2002$ & 12 & 203.90 & 312.10 & 256.12 & 255.60 & 30.48 & 8.80 \\
& $* 2003$ & 14 & 230.36 & 326.54 & 293.97 & 302.15 & 26.34 & 7.04 \\
& 2004 & 114 & 130.20 & 291.50 & 231.35 & 234.90 & 55.47 & 5.19 \\
& 2005 & 356 & 90.30 & 358.40 & 199.64 & 188.20 & 65.93 & 3.49 \\
& 2006 & 139 & 285.08 & 378.74 & 344.77 & 351.64 & 34.50 & 2.93 \\
& 2007 & 92 & 194.39 & 283.84 & 238.53 & 233.32 & 31.30 & 3.26 \\
& 2008 & 116 & 170.77 & 369.03 & 230.57 & 220.67 & 65.91 & 6.12 \\
& 2009 & 244 & 141.43 & 350.88 & 244.34 & 236.17 & 59.59 & 3.82 \\
\hline Night & $* 2002$ & 21 & 163.40 & 399.10 & 229.70 & 211.90 & 66.08 & 14.42 \\
& $* 2003$ & 81 & 148.32 & 358.34 & 210.22 & 173.88 & 58.80 & 6.53 \\
& 2004 & 641 & 140.90 & 283.90 & 175.39 & 157.30 & 41.45 & 1.64 \\
& 2005 & 1219 & 92.30 & 297.80 & 220.28 & 229.70 & 46.54 & 1.33 \\
& 2006 & 1074 & 166.68 & 399.28 & 324.97 & 335.88 & 49.67 & 1.52 \\
& 2007 & 1218 & 177.02 & 289.06 & 256.72 & 257.45 & 26.11 & 0.75 \\
& 2008 & 833 & 157.03 & 421.09 & 293.10 & 279.78 & 83.13 & 2.88 \\
& 2009 & 691 & 177.02 & 356.09 & 269.31 & 266.63 & 45.92 & 1.75 \\
\hline
\end{tabular}


Table G4 - Summary statistics of spill percentage during yearling Chinook salmon passage from data used in studies at McNary Dam in 2002-2009.

[ $N$, number of observations; Min, minimum; Max, maximum; SD, standard deviation; SE, standard error]

\begin{tabular}{rrrrrrrrl}
\hline & Year & \multicolumn{1}{c}{$\boldsymbol{N}$} & \multicolumn{1}{c}{ Min } & Max & \multicolumn{1}{c}{ Mean } & \multicolumn{1}{c}{ Median } & \multicolumn{1}{c}{ SD } & SE \\
\hline Overall & 2002 & 33 & 0.00 & 68.09 & 35.67 & 49.60 & 25.11 & 4.37 \\
& 2003 & 95 & 0.00 & 62.64 & 19.00 & 0.02 & 21.71 & 2.23 \\
& 2004 & 928 & 0.00 & 78.52 & 21.30 & 0.00 & 30.66 & 1.01 \\
& 2005 & 1862 & 0.00 & 78.84 & 36.30 & 35.82 & 21.96 & 0.51 \\
& 2006 & 1426 & 0.00 & 63.66 & 47.72 & 50.27 & 9.67 & 0.26 \\
& 2007 & 1583 & 36.80 & 42.41 & 40.58 & 40.70 & 0.61 & 0.02 \\
& 2008 & 1112 & 38.92 & 59.56 & 46.15 & 41.18 & 7.46 & 0.22 \\
& 2009 & 1117 & 38.77 & 59.13 & 42.97 & 40.85 & 4.01 & 0.12 \\
\hline Day & Overall & 8156 & 0.00 & 78.84 & 39.47 & 40.77 & 17.77 & 0.20 \\
\hline 2002 & 12 & 41.19 & 68.09 & 55.32 & 54.80 & 7.33 & 2.12 \\
& 2003 & 14 & 36.30 & 62.64 & 46.65 & 45.59 & 6.21 & 1.66 \\
& 2004 & 146 & 49.44 & 78.52 & 65.06 & 63.79 & 5.90 & 0.49 \\
& 2005 & 454 & 32.79 & 78.84 & 53.16 & 56.37 & 14.29 & 0.67 \\
& 2006 & 246 & 39.94 & 63.66 & 49.79 & 51.20 & 4.85 & 0.31 \\
& 2007 & 147 & 36.80 & 42.41 & 40.87 & 40.78 & 0.58 & 0.05 \\
& 2008 & 172 & 39.65 & 59.49 & 43.48 & 41.19 & 5.19 & 0.40 \\
& 2009 & 311 & 39.98 & 54.30 & 42.54 & 40.93 & 3.33 & 0.19 \\
\hline Night & 2002 & 21 & 0.00 & 62.61 & 24.44 & 19.44 & 24.81 & 5.41 \\
& 2003 & 81 & 0.00 & 56.92 & 14.22 & 0.00 & 19.76 & 2.20 \\
& 2004 & 782 & 0.00 & 71.29 & 13.14 & 0.00 & 26.16 & 0.94 \\
& 2005 & 1408 & 0.00 & 73.56 & 30.86 & 33.80 & 21.23 & 0.57 \\
& 2006 & 1180 & 0.00 & 61.65 & 47.29 & 50.06 & 10.34 & 0.30 \\
& 2007 & 1436 & 37.39 & 41.83 & 40.55 & 40.68 & 0.61 & 0.02 \\
& 2008 & 940 & 38.92 & 59.56 & 46.64 & 41.18 & 7.70 & 0.25 \\
& 2009 & 806 & 38.77 & 59.13 & 43.13 & 40.85 & 4.23 & 0.15 \\
\hline
\end{tabular}


Table G5 - Summary statistics of tag burden (percent) of yearling Chinook salmon from data used in studies at McNary Dam in 2002-2009.

[ $N$, number of observations; Min, minimum; Max, maximum; SD, standard deviation; SE, standard error]

\begin{tabular}{lrrrrrrrl}
\hline & Year & \multicolumn{1}{c}{$\boldsymbol{N}$} & Min & Max & Mean & Median & SD & SE \\
\hline Overall & 2002 & 33 & 2.12 & 4.35 & 3.35 & 3.28 & 0.54 & 0.09 \\
& 2003 & 95 & 3.47 & 9.78 & 6.96 & 7.06 & 1.17 & 0.12 \\
& 2004 & 928 & 1.42 & 6.96 & 4.86 & 4.97 & 1.24 & 0.04 \\
& 2005 & 1862 & 1.33 & 5.69 & 3.78 & 3.80 & 0.84 & 0.02 \\
& 2006 & 1426 & 2.52 & 6.64 & 4.93 & 4.95 & 0.84 & 0.02 \\
& 2007 & 1583 & 1.90 & 6.52 & 4.66 & 4.69 & 0.91 & 0.02 \\
& 2008 & 1112 & 1.96 & 6.52 & 4.39 & 4.36 & 0.96 & 0.03 \\
& 2009 & 1117 & 0.86 & 5.17 & 3.60 & 3.69 & 0.84 & 0.03 \\
& Overall & 8156 & 0.86 & 9.78 & 4.37 & 4.35 & 1.10 & 0.01 \\
\hline \multirow{6}{*}{ Day } & 2002 & 12 & 2.65 & 4.35 & 3.44 & 3.22 & 0.61 & 0.18 \\
& 2003 & 14 & 3.92 & 8.57 & 6.83 & 7.13 & 1.31 & 0.35 \\
& 2004 & 146 & 1.85 & 6.87 & 4.76 & 4.93 & 1.31 & 0.11 \\
& 2005 & 454 & 1.33 & 5.53 & 3.85 & 3.94 & 0.88 & 0.04 \\
& 2006 & 246 & 3.02 & 6.49 & 4.78 & 4.77 & 0.83 & 0.05 \\
& 2007 & 147 & 1.97 & 6.05 & 4.25 & 4.29 & 0.85 & 0.07 \\
& 2008 & 172 & 1.96 & 6.33 & 4.03 & 3.95 & 0.86 & 0.07 \\
& 2009 & 311 & 0.86 & 5.08 & 3.64 & 3.75 & 0.83 & 0.05 \\
\hline \multirow{6}{*}{ Night } & 2002 & 21 & 2.12 & 4.04 & 3.29 & 3.33 & 0.51 & 0.11 \\
& 2003 & 81 & 3.47 & 9.78 & 6.98 & 7.06 & 1.15 & 0.13 \\
& 2004 & 782 & 1.42 & 6.96 & 4.88 & 4.98 & 1.23 & 0.04 \\
& 2005 & 1408 & 1.54 & 5.69 & 3.76 & 3.77 & 0.83 & 0.02 \\
& 2006 & 1180 & 2.52 & 6.64 & 4.96 & 4.98 & 0.84 & 0.02 \\
& 2007 & 1436 & 1.90 & 6.52 & 4.70 & 4.75 & 0.90 & 0.02 \\
& 2008 & 940 & 2.18 & 6.52 & 4.46 & 4.44 & 0.96 & 0.03 \\
& 2009 & 806 & 1.26 & 5.17 & 3.59 & 3.68 & 0.85 & 0.03 \\
\hline
\end{tabular}


Table G6 - Summary statistics of temperature during yearling Chinook salmon passage from data used in studies at McNary Dam in 2002-2009.

[ $N$, number of observations; Min, minimum; Max, maximum; SD, standard deviation; SE, standard error]

\begin{tabular}{lrrrrrrrr}
\hline & Year & \multicolumn{1}{c}{$\boldsymbol{N}$} & \multicolumn{1}{c}{ Min } & Max & \multicolumn{1}{c}{ Mean } & Median & SD & SE \\
\hline Overall & 2002 & 33 & 10.00 & 14.30 & 11.80 & 11.80 & 1.12 & 0.20 \\
& 2003 & 95 & 10.50 & 15.33 & 12.04 & 11.78 & 1.14 & 0.12 \\
& 2004 & 928 & 10.22 & 13.72 & 12.51 & 12.83 & 0.84 & 0.03 \\
& 2005 & 1862 & 9.89 & 15.00 & 12.48 & 12.56 & 1.21 & 0.03 \\
& 2006 & 1426 & 9.50 & 14.60 & 12.49 & 12.60 & 1.39 & 0.04 \\
& 2007 & 1583 & 8.83 & 15.78 & 12.24 & 12.50 & 1.97 & 0.05 \\
& 2008 & 1112 & 8.28 & 13.56 & 10.96 & 11.33 & 1.66 & 0.05 \\
& 2009 & 1117 & 8.11 & 15.00 & 10.96 & 10.72 & 1.94 & 0.06 \\
& Overall & 8156 & 8.11 & 15.78 & 12.01 & 12.33 & 1.69 & 0.02 \\
\hline \multirow{6}{*}{ Day } & 2002 & 12 & 10.00 & 13.50 & 11.55 & 11.50 & 0.89 & 0.26 \\
& 2003 & 14 & 10.83 & 15.17 & 12.39 & 11.78 & 1.34 & 0.36 \\
& 2004 & 146 & 10.83 & 13.56 & 12.56 & 12.72 & 0.71 & 0.06 \\
& 2005 & 454 & 9.89 & 14.94 & 12.04 & 12.22 & 1.08 & 0.05 \\
& 2006 & 246 & 10.10 & 14.60 & 12.07 & 11.80 & 1.23 & 0.08 \\
& 2007 & 147 & 9.06 & 15.50 & 10.63 & 10.22 & 1.52 & 0.13 \\
& 2008 & 172 & 8.33 & 13.33 & 10.03 & 9.50 & 1.56 & 0.12 \\
& 2009 & 311 & 8.33 & 14.94 & 10.81 & 10.00 & 1.95 & 0.11 \\
\hline \multirow{6}{*}{ Night } & 2002 & 21 & 10.00 & 14.30 & 11.95 & 12.10 & 1.23 & 0.27 \\
& 2003 & 81 & 10.50 & 15.33 & 11.97 & 11.72 & 1.10 & 0.12 \\
& 2004 & 782 & 10.22 & 13.72 & 12.50 & 12.83 & 0.86 & 0.03 \\
& 2005 & 1408 & 10.06 & 15.00 & 12.62 & 12.56 & 1.22 & 0.03 \\
& 2006 & 1180 & 9.50 & 14.60 & 12.58 & 12.80 & 1.41 & 0.04 \\
& 2007 & 1436 & 8.83 & 15.78 & 12.40 & 12.56 & 1.94 & 0.05 \\
& 2008 & 940 & 8.28 & 13.56 & 11.13 & 11.44 & 1.62 & 0.05 \\
& 2009 & 806 & 8.11 & 15.00 & 11.02 & 10.89 & 1.94 & 0.07 \\
\hline
\end{tabular}




\section{Appendix H. Capture History Summary of Yearling Chinook Salmon from Data Used in Studies at McNary Dam in 2002-2005, and 2009.}

[Occ. represents the Occasion number after release. $R(i)$ represents numbers released and $j=2$ and 3 indicate the released number detected at each downstream site]

\begin{tabular}{ccccr}
\hline \multicolumn{5}{c}{ Group 1 control day 2004} \\
Occ. & R(i) & $\mathrm{j}=2$ & $\mathrm{j}=3$ & Total \\
\hline 1 & 641 & 299 & 162 & 461 \\
2 & 299 & & 163 & 163 \\
\multicolumn{5}{c}{ Group 2 control day 2005 } \\
Occ. & R(i) & $\mathrm{j}=2$ & $\mathrm{j}=3$ & Total \\
\hline 1 & 1219 & 1015 & 156 & 1171 \\
2 & 1015 & & 913 & 913
\end{tabular}

\begin{tabular}{ccccc}
\multicolumn{5}{c}{ Group 9 turbine day 2004} \\
Occ. & R(i) & $\mathrm{j}=2$ & $\mathrm{j}=3$ & Total \\
\hline 1 & 141 & 56 & 28 & 84 \\
2 & 56 & & 33 & 33
\end{tabular}

Group 3 control day 2009

Group 10 turbine day 2005

\begin{tabular}{rrrrr} 
Occ. & $\mathrm{R}(\mathrm{i})$ & $\mathrm{j}=2$ & $\mathrm{j}=3$ & Total \\
\hline 1 & 189 & 132 & 28 & 160 \\
2 & 132 & & 124 & 124
\end{tabular}

\begin{tabular}{rrrrr} 
Occ. & R(i) & $\mathrm{j}=2$ & $\mathrm{j}=3$ & Total \\
\hline 1 & 691 & 641 & 10 & 651 \\
2 & 641 & & 598 & 598
\end{tabular}

Group 4 control night 2004

Group 11 turbine day 2009

\begin{tabular}{rrrrr} 
Occ. & $\mathrm{R}(\mathrm{i})$ & $\mathrm{j}=2$ & $\mathrm{j}=3$ & Total \\
\hline 1 & 115 & 97 & 3 & 100 \\
2 & 97 & & 92 & 92
\end{tabular}

\begin{tabular}{rrrrr} 
Occ. & R(i) & $\mathrm{j}=2$ & $\mathrm{j}=3$ & Total \\
\hline 1 & 114 & 59 & 22 & 81 \\
2 & 59 & & 29 & 29
\end{tabular}

Group 12 turbine night 2002

\begin{tabular}{rrrrr} 
Occ. & $R(i)$ & $j=2$ & $j=3$ & Total \\
\hline 1 & 12 & 10 & 2 & 12 \\
2 & 10 & & 8 & 8
\end{tabular}

Group 5 control night 2005

Group 13 turbine night 2003

\begin{tabular}{rrrrr} 
Occ. & R(i) & $\mathrm{j}=2$ & $\mathrm{j}=3$ & Total \\
\hline 1 & 356 & 295 & 47 & 342 \\
2 & 295 & & 269 & 269
\end{tabular}

\begin{tabular}{rrrrr} 
Occ. & $\mathrm{R}(\mathrm{i})$ & $\mathrm{j}=2$ & $\mathrm{j}=3$ & Total \\
\hline 1 & 14 & 4 & 4 & 8 \\
2 & 4 & & 4 & 4
\end{tabular}

Group 6 control night 2009

Group 14 turbine night 2004

\begin{tabular}{rrrrr} 
Occ. & $R(i)$ & $j=2$ & $j=3$ & Total \\
\hline 1 & 244 & 233 & 6 & 239 \\
2 & 233 & & 220 & 220
\end{tabular}

\begin{tabular}{rrrrr} 
Occ. & $R(\mathrm{i})$ & $\mathrm{j}=2$ & $\mathrm{j}=3$ & Total \\
\hline 1 & 32 & 14 & 4 & 18 \\
2 & 14 & & 9 & 9
\end{tabular}

Group 7 turbine day 2002

Group 15 turbine night 2005

\begin{tabular}{rrrrr} 
Occ. & R(i) & $\mathrm{j}=2$ & $\mathrm{j}=3$ & Total \\
\hline 1 & 21 & 15 & 3 & 18 \\
2 & 15 & & 14 & 14
\end{tabular}

\begin{tabular}{rrrrr} 
Occ. & $\mathrm{R}(\mathrm{i})$ & $\mathrm{j}=2$ & $\mathrm{j}=3$ & Total \\
\hline 1 & 98 & 77 & 11 & 88 \\
2 & 77 & & 71 & 71
\end{tabular}

Group 8 turbine day 2003

Group 16 turbine night 2009

\begin{tabular}{|c|c|c|c|c|c|c|c|c|c|}
\hline Occ. & R(i) & $j=2$ & $j=3$ & Total & Occ. & $\mathrm{R}(\mathrm{i})$ & $\mathrm{j}=2$ & $j=3$ & Total \\
\hline 1 & 81 & 38 & 18 & 56 & 1 & 67 & 59 & 0 & 59 \\
\hline 2 & 38 & & 17 & 17 & 2 & 59 & & 54 & 54 \\
\hline
\end{tabular}




\section{Appendix I. Correlation Analyses of Yearling Chinook Salmon from Data Used in Studies at McNary Dam in 2002-2005, and 2009.}

Table I1. Table of correlation indices of data from yearling Chinook salmon from the turbine group at McNary Dam in 2002-2005 and 2009.

[Pearson correlation coefficients are listed above the probabilities of obtaining a greater value under the hypothesis that $\mathrm{Rho}=0$. Sample size is 770 ; $<$, less than; see table 2 for variable name definitions]

\begin{tabular}{|c|c|c|c|c|c|c|c|c|c|}
\hline & TOTQ & PER_SPI & HEAD & TURQ & TURLOC & РНОТО & TEMP & WEIGHT & $\begin{array}{c}\text { TAG } \\
\text { BURDEN }\end{array}$ \\
\hline TОTQ & 1.0000 & $\begin{array}{r}0.5980 \\
<0.0001\end{array}$ & $\begin{array}{l}-0.7568 \\
<0.0001\end{array}$ & $\begin{array}{l}0.0105 \\
0.7714\end{array}$ & $\begin{array}{r}0.1995 \\
<0.0001\end{array}$ & $\begin{array}{r}0.2288 \\
<0.0001\end{array}$ & $\begin{array}{l}0.1362 \\
0.0001\end{array}$ & $\begin{array}{l}0.1116 \\
0.0019\end{array}$ & $\begin{array}{r}-0.0791 \\
0.0282\end{array}$ \\
\hline PER_SPI & & 1.0000 & $\begin{array}{l}-0.1566 \\
<0.0001\end{array}$ & $\begin{array}{l}-0.3468 \\
<0.0001\end{array}$ & $\begin{array}{l}0.0338 \\
0.3487\end{array}$ & $\begin{array}{r}0.5888 \\
<0.0001\end{array}$ & $\begin{array}{r}-0.0901 \\
0.0124\end{array}$ & $\begin{array}{l}0.1169 \\
0.0012\end{array}$ & $\begin{array}{l}-0.2090 \\
<0.0001\end{array}$ \\
\hline HEAD & & & 1.0000 & $\begin{array}{l}-0.2068 \\
<0.0001\end{array}$ & $\begin{array}{l}-0.2034 \\
<0.0001\end{array}$ & $\begin{array}{r}-0.0005 \\
0.9893\end{array}$ & $\begin{array}{l}-0.1870 \\
<0.0001\end{array}$ & $\begin{array}{r}-0.1325 \\
0.0002\end{array}$ & $\begin{array}{r}-0.0170 \\
0.6377\end{array}$ \\
\hline TURQ & & & & 1.0000 & $\begin{array}{r}-0.0145 \\
0.6878\end{array}$ & $\begin{array}{l}-0.2136 \\
<0.0001\end{array}$ & $\begin{array}{r}0.1912 \\
<0.0001\end{array}$ & $\begin{array}{l}0.0193 \\
0.5933\end{array}$ & $\begin{array}{r}0.1448 \\
<0.0001\end{array}$ \\
\hline TURLOC & & & & & 1.0000 & $\begin{array}{r}-0.0616 \\
0.0875\end{array}$ & $\begin{array}{l}-0.2044 \\
<0.0001\end{array}$ & $\begin{array}{l}0.0422 \\
0.2426\end{array}$ & $\begin{array}{l}0.0397 \\
0.2708\end{array}$ \\
\hline РНОТО & & & & & & 1.0000 & $\begin{array}{r}-0.0912 \\
0.0114\end{array}$ & $\begin{array}{l}0.0223 \\
0.5371\end{array}$ & $\begin{array}{r}-0.1044 \\
0.0037\end{array}$ \\
\hline TEMP & & & & & & & 1.0000 & $\begin{array}{r}-0.1309 \\
0.0003\end{array}$ & $\begin{array}{l}0.0780 \\
0.0305\end{array}$ \\
\hline WEIGHT & & & & & & & & 1.0000 & $\begin{array}{l}-0.7305 \\
<0.0001 \\
\end{array}$ \\
\hline
\end{tabular}


Table 12. Table of correlation indices of data from yearling Chinook salmon from the control group at McNary Dam in 2002-2005 and 2009.

[Pearson correlation coefficients are listed above the probabilities of obtaining a greater value under the hypothesis that $\mathrm{Rho}=0$. Sample size is 3,$265 ;<$, less than; see table 2 for variable name definitions]

\begin{tabular}{|c|c|c|c|c|c|c|}
\hline & TOTQ & PER_SPI & РНОTO & TEMP & WEIGHT & $\begin{array}{c}\text { TAG } \\
\text { BURDEN }\end{array}$ \\
\hline TOTQ & 1.0000 & $\begin{array}{r}0.5410 \\
<0.0001\end{array}$ & $\begin{array}{r}-0.0163 \\
0.3529\end{array}$ & $\begin{array}{r}0.2874 \\
<0.0001\end{array}$ & $\begin{array}{r}0.1694 \\
<0.0001\end{array}$ & $\begin{array}{l}-0.1926 \\
<0.0001\end{array}$ \\
\hline PER_SPI & & 1.0000 & $\begin{array}{r}0.3768 \\
<0.0001\end{array}$ & $\begin{array}{l}0.0059 \\
0.7353\end{array}$ & $\begin{array}{l}0.0549 \\
0.0017\end{array}$ & $\begin{array}{l}-0.1419 \\
<0.0001\end{array}$ \\
\hline РНОТО & & & 1.0000 & $\begin{array}{l}-0.1241 \\
<0.0001\end{array}$ & $\begin{array}{l}0.0118 \\
0.4997\end{array}$ & $\begin{array}{r}-0.0311 \\
0.0759\end{array}$ \\
\hline TEMP & & & & 1.0000 & $\begin{array}{l}-0.1200 \\
<0.0001\end{array}$ & $\begin{array}{r}0.0812 \\
<0.0001\end{array}$ \\
\hline WEIGHT & & & & & 1.0000 & $\begin{array}{l}-0.7973 \\
<0.0001\end{array}$ \\
\hline
\end{tabular}




\section{Appendix J. Model Summary from Analyses of Recapture Probabilities ( $p$ ) of Yearling Chinook Salmon from Data Used in Studies at McNary Dam in 2002-2005, and 2009.}

[Models of $\mathrm{p}$ include those in which values can vary in various combinations of detection site ( $\mathrm{t}$ ) and group (treatment, year, and photoperiod). A '*' indicated a multiplicative effect, a '+' indicates an additive effect, and a '.' indicates a common value fitted to all groups and reaches. A multiplicative model ( $\mathrm{g} * \mathrm{t}$ ) of apparent survival (phi) was used in all models. $\mathrm{K}$ indicates the number of estimable parameters]

\begin{tabular}{lrrrrrr}
\hline \multicolumn{1}{c}{ Model } & AlCc & $\begin{array}{c}\text { Delta } \\
\text { AlCc }\end{array}$ & $\begin{array}{c}\text { AlCc } \\
\text { Weights }\end{array}$ & $\begin{array}{c}\text { Model } \\
\text { Likelihood }\end{array}$ & K & Deviance \\
\hline$\left\{1\right.$ Phi $\left.\left(\mathrm{g}^{*} \mathrm{t}\right), \mathrm{p}(\mathrm{g} * \mathrm{t})\right\}$ & 7216.47 & 0.00 & 1.00 & 1.00 & 48 & 7119.80 \\
$\{2 \mathrm{Phi}(\mathrm{g} * \mathrm{t}), \mathrm{p}(\mathrm{g}+\mathrm{t})\}$ & 7283.83 & 67.36 & 0.00 & 0.00 & 48 & 7187.16 \\
$\{3$ Phi $(\mathrm{g} * \mathrm{t}), \mathrm{p}(\mathrm{g})\}$ & 7298.73 & 82.27 & 0.00 & 0.00 & 48 & 7202.07 \\
$\{4$ Phi $(\mathrm{g} * \mathrm{t}), \mathrm{p}(\mathrm{t})\}$ & 8004.71 & 788.24 & 0.00 & 0.00 & 33 & 7938.39 \\
$\{5$ Phi $(\mathrm{g} * \mathrm{t}), \mathrm{p}()\}$. & 8037.00 & 820.53 & 0.00 & 0.00 & 33 & 7970.68 \\
\hline
\end{tabular}




\section{Appendix K. Model-selection Results from Radio- and Acoustic-tagged Yearling Chinook Salmon from Data Used in Studies at McNary Dam in 2002-2005, and 2009.}

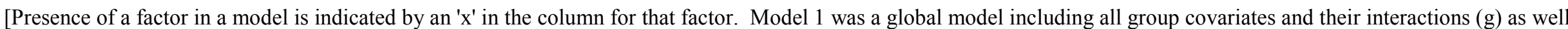
as all individual covariates and interactions listed. Distance to the first downriver gate (gated) was only used when year was present in the model. All models shared a common year*reach model of recapture probability. K indicates the number of parameters.]

\begin{tabular}{|c|c|c|c|c|c|c|c|c|c|c|c|c|c|c|c|c|c|c|c|c|c|c|c|c|c|c|c|c|}
\hline \multirow[b]{3}{*}{$\begin{array}{l}\text { Model } \\
\text { Number }\end{array}$} & \multirow{2}{*}{\multicolumn{8}{|c|}{ Group Covariates }} & \multicolumn{17}{|c|}{ Individual Covariates } & \multirow{2}{*}{\multicolumn{3}{|c|}{ Model Selection Results }} \\
\hline & & & & & & & & & \multicolumn{8}{|c|}{ Biological } & \multicolumn{9}{|c|}{ Operational } & & & \\
\hline & ס & \pm & 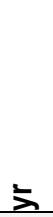 & $\begin{array}{l}\text { 융 } \\
\text { 등 }\end{array}$ & $\stackrel{+}{ \pm}$ & 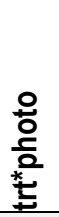 & $\begin{array}{l}\text { 옹 } \\
\text { 응 } \\
\text { 눈 }\end{array}$ & 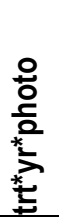 & 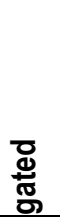 & $\xi$ & 윢 & 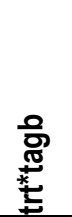 & 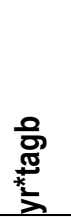 & 을 & 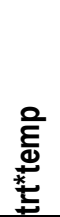 & 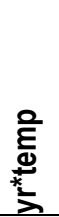 & 음 & 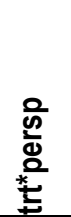 & 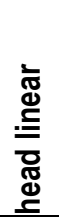 & 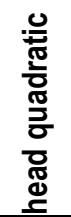 & 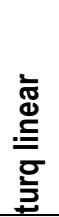 & 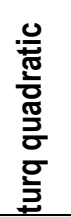 & 은 & 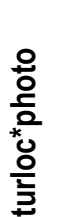 & 몽 & AlCc & $\mathrm{K}$ & Deviance \\
\hline 1 & $\mathrm{x}$ & $\mathrm{x}$ & $\mathrm{x}$ & $\mathrm{x}$ & $\mathrm{x}$ & $\mathrm{x}$ & $x$ & $\mathrm{x}$ & & & $x$ & $\mathrm{x}$ & $x$ & $\mathrm{x}$ & $\mathrm{X}$ & $x$ & $\mathrm{x}$ & $\mathrm{x}$ & $\mathrm{x}$ & & $\mathrm{x}$ & & $\mathrm{x}$ & $x$ & $\mathrm{x}$ & 7216.4 & 64 & 7087.2 \\
\hline 3 & $\mathrm{x}$ & $\mathrm{x}$ & $\mathrm{x}$ & $\mathrm{x}$ & $\mathrm{X}$ & $\hat{x}$ & $\mathrm{x}$ & $\hat{x}$ & & & $\mathrm{x}$ & x & & $\mathrm{x}$ & $\mathrm{x}$ & & $\mathrm{x}$ & $\mathrm{x}$ & $\mathrm{X}$ & & $\mathrm{X}$ & & $\mathrm{X}$ & $\mathrm{X}$ & $\hat{x}$ & 7206.0 & 56 & 7093.0 \\
\hline $4 a$ & & $\mathrm{x}$ & & $\mathrm{x}$ & & $\mathrm{x}$ & & & $\mathrm{x}$ & & $\mathrm{x}$ & $\mathrm{x}$ & & $\mathrm{x}$ & $\mathrm{x}$ & & $\mathrm{x}$ & $\mathrm{x}$ & $\mathrm{x}$ & & $\mathrm{x}$ & & $\mathrm{x}$ & $\mathrm{x}$ & $\mathrm{x}$ & 7215.7 & 45 & 7125.2 \\
\hline $4 \mathrm{~b}$ & & $\mathrm{x}$ & $\mathrm{x}$ & $\hat{x}$ & $\mathrm{x}$ & $\hat{x}$ & $\mathrm{x}$ & & & & $\hat{x}$ & $\hat{x}$ & & $\hat{x}$ & $\hat{\mathrm{X}}$ & & $\hat{x}$ & $\hat{\mathrm{X}}$ & $\hat{x}$ & & $\hat{\mathrm{X}}$ & & $\hat{\mathrm{X}}$ & $\hat{X}$ & $\hat{X}$ & 7205.6 & 54 & 7096.8 \\
\hline $\begin{array}{l}40 \\
4 c\end{array}$ & & $\begin{array}{l}\mathrm{X} \\
\mathrm{X}\end{array}$ & $\begin{array}{l}X \\
X\end{array}$ & $\begin{array}{l}X \\
X\end{array}$ & & $\begin{array}{l}X \\
X\end{array}$ & $\begin{array}{l}X \\
X\end{array}$ & & & & $\begin{array}{l}X \\
X\end{array}$ & $\begin{array}{l}x \\
x\end{array}$ & & $\begin{array}{l}x \\
x\end{array}$ & $\begin{array}{l}\mathrm{X} \\
\mathrm{X}\end{array}$ & & $\begin{array}{l}X \\
X\end{array}$ & $\begin{array}{l}\mathrm{X} \\
\mathrm{X}\end{array}$ & $\begin{array}{l}\lambda \\
\mathrm{X}\end{array}$ & & $\begin{array}{l}X \\
X\end{array}$ & & $\begin{array}{l}X \\
X\end{array}$ & $\begin{array}{l}X \\
X\end{array}$ & $\begin{array}{l}X \\
X\end{array}$ & 7203.2 & 52 & 7098.4 \\
\hline $4 d$ & & $\mathrm{x}$ & $\mathrm{x}$ & $\mathrm{x}$ & & $\mathrm{x}$ & & & & & $\mathrm{x}$ & $\mathrm{x}$ & & $\mathrm{X}$ & $\begin{array}{l}\mathrm{A} \\
\mathrm{X}\end{array}$ & & $\hat{X}$ & $\begin{array}{l}\mathrm{A} \\
\mathrm{X}\end{array}$ & $\begin{array}{l}\mathrm{A} \\
\mathrm{X}\end{array}$ & & $\begin{array}{l}\hat{X} \\
\mathrm{X}\end{array}$ & & $\begin{array}{l}\mathrm{A} \\
\mathrm{X}\end{array}$ & $\begin{array}{l}\mathrm{X} \\
\mathrm{X}\end{array}$ & $\begin{array}{l}\mathrm{X} \\
\mathrm{X}\end{array}$ & 7204.0 & 48 & 7107.3 \\
\hline 5 & & $\mathrm{x}$ & $\mathrm{X}$ & $\mathrm{x}$ & & $\mathrm{x}$ & $\mathrm{x}$ & & & & $\mathrm{x}$ & $\mathrm{x}$ & & $\mathrm{X}$ & $\mathrm{X}$ & & $\mathrm{X}$ & $\mathrm{X}$ & $\mathrm{X}$ & & $\mathrm{X}$ & & $\mathrm{X}$ & & $\mathrm{X}$ & 7201.8 & 51 & 7099.0 \\
\hline 6 & & $\mathrm{x}$ & $\mathrm{x}$ & $\mathrm{X}$ & & & $\mathrm{X}$ & & & & $\mathrm{X}$ & $\mathrm{x}$ & & $\mathrm{X}$ & $\mathrm{X}$ & & $\mathrm{x}$ & $\mathrm{X}$ & $\mathrm{X}$ & & $\hat{x}$ & & $\mathrm{X}$ & & $\mathrm{X}$ & 7200.4 & 50 & 7099.6 \\
\hline $\begin{array}{l}0 \\
7\end{array}$ & & $\begin{array}{l}x \\
x\end{array}$ & $\begin{array}{l}x \\
x\end{array}$ & $x$ & & & $\begin{array}{l}X \\
X\end{array}$ & & & & $\begin{array}{l}\mathrm{X} \\
\mathrm{x}\end{array}$ & $\begin{array}{l}x \\
x\end{array}$ & & $\begin{array}{l}X \\
X\end{array}$ & $\begin{array}{l}x \\
X\end{array}$ & & $\begin{array}{l}x \\
x\end{array}$ & $\begin{array}{l}x \\
x\end{array}$ & $\begin{array}{l}\mathrm{X} \\
\mathrm{X}\end{array}$ & & $\begin{array}{l}\mathrm{X} \\
\mathrm{X}\end{array}$ & & $\begin{array}{l}x \\
X\end{array}$ & & $\begin{array}{l}\mathrm{X} \\
\mathrm{X}\end{array}$ & 7198.7 & 49 & 7100.0 \\
\hline 8 & & $\mathrm{x}$ & $\mathrm{x}$ & & & & $\mathrm{X}$ & & & & $\mathrm{X}$ & $\mathrm{x}$ & & $\mathrm{X}$ & & & $\begin{array}{l}\mathrm{X} \\
\mathrm{X}\end{array}$ & $\begin{array}{l}\mathrm{A} \\
\mathrm{X}\end{array}$ & $\begin{array}{l}\mathrm{A} \\
\mathrm{X}\end{array}$ & & $\begin{array}{l}\mathrm{A} \\
\mathrm{X}\end{array}$ & & $\begin{array}{l}\mathrm{A} \\
\mathrm{X}\end{array}$ & & $\begin{array}{l}\mathrm{X} \\
\mathrm{X}\end{array}$ & 7197.3 & 48 & 7100.6 \\
\hline 9 & & $\mathrm{x}$ & $\mathrm{x}$ & & & & $\mathrm{x}$ & & & & $\mathrm{X}$ & x & & $\mathrm{X}$ & & & $\mathrm{X}$ & & $\mathrm{X}$ & & $\hat{x}$ & & $\mathrm{X}$ & & $\mathrm{X}$ & 7195.3 & 47 & 7100.7 \\
\hline 11 & & $\mathrm{~A}$ & $\mathrm{X}$ & & & & $\mathrm{X}$ & & & & $\hat{X}$ & $\hat{x}$ & & $\mathrm{x}$ & & & $\mathrm{X}$ & & $\mathrm{A}$ & & $\hat{x}$ & & $\hat{X}$ & & & 7198.1 & 46 & 7105.5 \\
\hline 12 & & $\begin{array}{l}\mathrm{A} \\
\mathrm{X}\end{array}$ & $\begin{array}{l}\mathrm{X} \\
\mathrm{X}\end{array}$ & & & & $\begin{array}{l}\mathrm{X} \\
\mathrm{X}\end{array}$ & & & & $\begin{array}{l}\mathrm{A} \\
\mathrm{X}\end{array}$ & $\begin{array}{l}\mathrm{A} \\
\mathrm{x}\end{array}$ & & $\begin{array}{l}\mathbf{X} \\
\mathrm{X}\end{array}$ & & & & & $\begin{array}{l}\mathrm{A} \\
\mathrm{X}\end{array}$ & & $\begin{array}{l}\hat{X} \\
\mathrm{X}\end{array}$ & & $\begin{array}{l}\mathbf{A} \\
\mathrm{X}\end{array}$ & & $\mathrm{x}$ & 7201.0 & 46 & 7108.3 \\
\hline 13 & & $\begin{array}{l}\mathrm{A} \\
\mathrm{X}\end{array}$ & $\begin{array}{l}\mathrm{X} \\
\mathrm{X}\end{array}$ & & & & $\begin{array}{l}\mathrm{X} \\
\mathrm{X}\end{array}$ & & & & $\begin{array}{l}\Lambda \\
X\end{array}$ & $\begin{array}{l}\mathrm{A} \\
\mathrm{x}\end{array}$ & & $\begin{array}{l}\mathbf{X} \\
\mathrm{X}\end{array}$ & & & $\mathrm{x}$ & & $\begin{array}{l}\mathrm{A} \\
\mathrm{X}\end{array}$ & & $\begin{array}{l}\hat{X} \\
\mathrm{X}\end{array}$ & & & & $\begin{array}{l}\mathrm{A} \\
\mathrm{X}\end{array}$ & 7194.9 & 46 & 7102.3 \\
\hline $14 a$ & & $\mathrm{x}$ & $\mathrm{x}$ & & & & $\mathrm{x}$ & & & & $\mathrm{x}$ & $\mathrm{x}$ & & $\mathrm{x}$ & & & $\mathrm{x}$ & & & & $\mathrm{x}$ & & & & $\mathrm{x}$ & 7195.6 & 45 & 7105.0 \\
\hline $14 \mathrm{~b}$ & & $\mathrm{x}$ & $\mathrm{x}$ & & & & $\mathrm{x}$ & & & & $\mathrm{x}$ & $\mathrm{x}$ & & $\mathrm{x}$ & & & $\mathrm{x}$ & & & $\mathrm{x}$ & $\mathrm{x}$ & & & & $\mathrm{X}$ & 7195.9 & 47 & 7101.2 \\
\hline $\begin{array}{l}140 \\
15 a\end{array}$ & & $\begin{array}{l}x \\
x\end{array}$ & $\begin{array}{l}x \\
x\end{array}$ & & & & $\begin{array}{l}x \\
x\end{array}$ & & & & $\begin{array}{l}x \\
x\end{array}$ & $\begin{array}{l}x \\
x\end{array}$ & & $\begin{array}{l}x \\
x\end{array}$ & & & $\begin{array}{l}x \\
x\end{array}$ & & $\mathrm{x}$ & & & & & & $\begin{array}{l}x \\
X\end{array}$ & 7192.9 & $\begin{array}{l}41 \\
45\end{array}$ & 7102.3 \\
\hline $15 \mathrm{~b}$ & & $\begin{array}{l}\lambda \\
X\end{array}$ & $\begin{array}{l}\mathrm{X} \\
\mathrm{X}\end{array}$ & & & & $\begin{array}{l}\lambda \\
X\end{array}$ & & & & $\begin{array}{l}\mathrm{A} \\
\mathrm{X}\end{array}$ & $\begin{array}{l}\lambda \\
x\end{array}$ & & $\begin{array}{l}\lambda \\
X\end{array}$ & & & $\begin{array}{l}\boldsymbol{X} \\
\mathrm{X}\end{array}$ & & $\begin{array}{l}\mathrm{A} \\
\mathrm{X}\end{array}$ & & & $\mathrm{x}$ & & & $\begin{array}{l}\mathrm{A} \\
\mathrm{X}\end{array}$ & 7195.9 & 47 & 7101.3 \\
\hline $16^{*}$ & & $\mathrm{x}$ & $\mathrm{x}$ & & & & $\mathrm{x}$ & & & & $\mathrm{X}$ & & & $\mathrm{X}$ & & & $\mathrm{X}$ & & $\mathrm{X}$ & & & & & & $\mathrm{X}$ & 7191.3 & 44 & 7102.8 \\
\hline 17 & & $\mathrm{x}$ & $\mathrm{x}$ & & & & $\mathrm{x}$ & & & & & & & $\hat{x}$ & & & $\mathrm{X}$ & & $\mathrm{X}$ & & & & & & $\begin{array}{l}\mathrm{A} \\
\mathrm{X}\end{array}$ & 7196.1 & 43 & 7109.6 \\
\hline 18 & & & & & & & & & & $\mathrm{x}$ & & & & & & & & & & & & & & & & 7196.5 & 44 & 7102.9 \\
\hline
\end{tabular}




\section{Appendix L. Beta (Slope) Coefficients of Estimable Survival Parameters of Yearling Chinook Salmon from Data Used in Studies at McNary Dam in 2002-2005, and 2009.}

[The data are from model 16 in appendix L]

\begin{tabular}{lcccr}
\hline & & Standard & \multicolumn{2}{c}{$95 \%$ Confidence } \\
\cline { 4 - 5 } \multicolumn{1}{c}{ Parameter } & Beta & Error & Lower & Upper \\
\hline intercept & 5.403126 & 0.880395 & 3.677551 & 7.128701 \\
treatment & 14.439400 & 8.404396 & -2.033210 & 30.912020 \\
2005 & 0.836723 & 0.290310 & 0.267715 & 1.405731 \\
2009 & -0.443710 & 0.367891 & -1.164770 & 0.277360 \\
2002 & 0.259362 & 0.743256 & -1.197420 & 1.716145 \\
2003 & 1.709109 & 1.345273 & -0.927630 & 4.345844 \\
photo*2005 & 0.040509 & 0.361362 & -0.667760 & 0.748779 \\
photo*2009 & 0.743644 & 0.331634 & 0.093642 & 1.393646 \\
photo*2003 & -2.505620 & 1.473538 & -5.393760 & 0.382511 \\
tag burden & -0.214470 & 0.084410 & -0.379920 & -0.049030 \\
persp & 0.005215 & 0.004853 & -0.004300 & 0.014726 \\
head & -0.201670 & 0.112947 & -0.423040 & 0.019711 \\
totq & 0.005538 & 0.002532 & 0.000577 & 0.010500 \\
temp & -0.259040 & 0.066728 & -0.389820 & -0.128250 \\
\hline
\end{tabular}




\section{Appendix M. Capture History Summary of Yearling Chinook Salmon from Data Used in Studies at McNary Dam in 2002-2005, and 2009.}

[Occ. represents the Occasion number after release. $R(i)$ represents numbers released and $j=2$ and 3 indicate the released number detected at each downstream site]

\begin{tabular}{|c|c|c|c|c|}
\hline \multicolumn{5}{|c|}{ Group 1 control day 2004} \\
\hline Occ. & $\mathrm{R}(\mathrm{i})$ & $\mathrm{j}=2$ & $j=3$ & Total \\
\hline 1 & 641 & 299 & 162 & 461 \\
\hline 2 & 299 & & 163 & 163 \\
\hline \multicolumn{5}{|c|}{ Group 2 control day 2005} \\
\hline Occ. & $\mathrm{R}(\mathrm{i})$ & $j=2$ & $\mathrm{j}=3$ & Total \\
\hline 1 & 1219 & 1015 & 156 & 1171 \\
\hline 2 & 1015 & & 913 & 913 \\
\hline
\end{tabular}

Group 3 control day 2006

\begin{tabular}{ccccc} 
Occ. & $R(i)$ & $j=2$ & $j=3$ & Total \\
\hline 1 & 1074 & 923 & 107 & 1030
\end{tabular}

$2923 \quad 840 \quad 840$

Group 4 control day 2007

\begin{tabular}{rrrrr} 
Occ. & $R(i)$ & $j=2$ & $j=3$ & Total \\
\hline 1 & 1218 & 386 & 715 & 1101 \\
2 & 386 & & 334 & 334
\end{tabular}

Group 5 control day 2008

\begin{tabular}{rrrrr} 
Occ. & $R(i)$ & $j=2$ & $j=3$ & Total \\
\hline 1 & 833 & 623 & 187 & 810 \\
2 & 623 & & 589 & 589
\end{tabular}

Group 6 control day 2009

\begin{tabular}{rrrrr} 
Occ. & $R(i)$ & $j=2$ & $j=3$ & Total \\
\hline 1 & 691 & 641 & 10 & 651 \\
2 & 641 & & 598 & 598
\end{tabular}

Group 7control night 2004

\begin{tabular}{rrrrr} 
Occ. & $R(i)$ & $j=2$ & $j=3$ & Total \\
\hline 1 & 114 & 59 & 22 & 81 \\
2 & 59 & & 29 & 29
\end{tabular}

Group 8 control night 2005

\begin{tabular}{rrrrr} 
Occ. & $R(\mathrm{i})$ & $\mathrm{j}=2$ & $\mathrm{j}=3$ & Total \\
\hline 1 & 356 & 295 & 47 & 342 \\
2 & 295 & & 269 & 269
\end{tabular}

Group 9 control night 2006

\begin{tabular}{rrrrr} 
Occ. & $R(i)$ & $j=2$ & $j=3$ & Total \\
\hline 1 & 139 & 91 & 45 & 136 \\
2 & 91 & & 76 & 76
\end{tabular}

\begin{tabular}{|c|c|c|c|c|}
\hline \multicolumn{5}{|c|}{ Group 10 control night 2007} \\
\hline Occ. & $\mathrm{R}(\mathrm{i})$ & $\mathrm{j}=2$ & $\mathrm{j}=3$ & Total \\
\hline 1 & 92 & 39 & 42 & 81 \\
\hline 2 & 39 & & 35 & 35 \\
\hline \multicolumn{5}{|c|}{ Group 11 control night 2008} \\
\hline Occ. & $\mathrm{R}(\mathrm{i})$ & $\mathrm{j}=2$ & $\mathrm{j}=3$ & Total \\
\hline 1 & 116 & 98 & 17 & 115 \\
\hline 2 & 98 & & 92 & 92 \\
\hline
\end{tabular}

Group 12 control night 2009

\begin{tabular}{rrrrr} 
Occ. & $R(i)$ & $j=2$ & $j=3$ & Total \\
\hline 1 & 244 & 233 & 6 & 239 \\
2 & 233 & & 220 & 220
\end{tabular}

Group 13 turbine day 2002

\begin{tabular}{rrrrr} 
Occ. & $R(i)$ & $j=2$ & $j=3$ & Total \\
\hline 1 & 21 & 15 & 3 & 18 \\
2 & 15 & & 14 & 14
\end{tabular}

Group 14 turbine day 2003

\begin{tabular}{rrrrr} 
Occ. & $R(\mathrm{i})$ & $\mathrm{j}=2$ & $\mathrm{j}=3$ & Total \\
\hline 1 & 81 & 38 & 18 & 56 \\
2 & 38 & & 17 & 17
\end{tabular}

Group 15 turbine day 2004

\begin{tabular}{rrrrr} 
Occ. & $R(\mathrm{i})$ & $\mathrm{j}=2$ & $\mathrm{j}=3$ & Total \\
\hline 1 & 141 & 56 & 28 & 84 \\
2 & 56 & & 33 & 33
\end{tabular}

Group 16 turbine day 2005

\begin{tabular}{rrrrr} 
Occ. & $R(\mathrm{i})$ & $\mathrm{j}=2$ & $\mathrm{j}=3$ & Total \\
\hline 1 & 189 & 132 & 28 & 160 \\
2 & 132 & & 124 & 124
\end{tabular}

Group 17 turbine day 2006

\begin{tabular}{ccccc} 
Occ. & $R(\mathrm{i})$ & $\mathrm{j}=2$ & $\mathrm{j}=3$ & Total \\
\hline 1 & 106 & 70 & 11 & 81 \\
2 & 70 & & 65 & 65
\end{tabular}

Group 18 turbine day 2007

\begin{tabular}{ccccc} 
Occ. & $R(\mathrm{i})$ & $\mathrm{j}=2$ & $\mathrm{j}=3$ & Total \\
\hline 1 & 218 & 70 & 89 & 159
\end{tabular}

270

63
Group 19 turbine day 2008

Occ. $\quad R(i) \quad j=2 \quad j=3 \quad$ Total

$\begin{array}{lllll}1 & 107 & 80 & 12 & 92 \\ 2 & 80 & & 73 & 73\end{array}$

Group 20 turbine day 2009

\begin{tabular}{ccccc} 
Occ. & $R(i)$ & $j=2$ & $j=3$ & Total \\
\hline 1 & 115 & 97 & 3 & 100
\end{tabular}

$\begin{array}{llll}2 & 97 & 92 & 92\end{array}$

Group 21 turbine night 2002

\begin{tabular}{rrrrr} 
Occ. & $R(i)$ & $j=2$ & $j=3$ & Total \\
\hline 1 & 12 & 10 & 2 & 12 \\
2 & 10 & & 8 & 8
\end{tabular}

Group 22 turbine night 2003

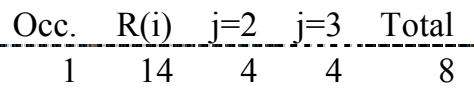

$\begin{array}{llll}2 & 4 & 4\end{array}$

Group 23 turbine night 2004

\begin{tabular}{rrrrr} 
Occ. & $R(i)$ & $j=2$ & $j=3$ & Total \\
\hline 1 & 32 & 14 & 4 & 18 \\
2 & 14 & & 9 & 9
\end{tabular}

Group 24 turbine night 2005

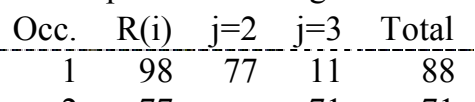

$\begin{array}{llll}2 & 77 & 71 & 71\end{array}$

Group 25 turbine night 2006

Occ. R(i) $\mathrm{j}=2 \quad \mathrm{j}=3$ Total

$\begin{array}{rrrrr}1 & 107 & 80 & 13 & 93 \\ 2 & 80 & & 78 & 78\end{array}$

Group 26 turbine night 2007

\begin{tabular}{ccccc} 
Occ. & $R(\mathrm{i})$ & $\mathrm{j}=2$ & $\mathrm{j}=3$ & Total \\
\hline 1 & 55 & 17 & 32 & 49
\end{tabular}

$\begin{array}{llll}2 & 17 & 15 & 15\end{array}$

Group 27 turbine night 2008

\begin{tabular}{rrrrr} 
Occ. & $R(i)$ & $j=2$ & $j=3$ & Total \\
\hline 1 & 56 & 31 & 21 & 52 \\
2 & 31 & & 30 & 30
\end{tabular}

Group 28 turbine night 2009

\begin{tabular}{ccccc} 
Occ. & $R(i)$ & $j=2$ & $j=3$ & Total \\
\hline 1 & 67 & 59 & 0 & 59
\end{tabular}

$\begin{array}{llll}2 & 59 & 54 & 54\end{array}$ 


\section{Appendix N. Model Summary from Analyses of Recapture Probabilities ( $p$ ) of Yearling Chinook Salmon from Data Used in Studies at McNary Dam in 2002-2005, and 2009.}

[Models of $p$ include those in which values can vary in various combinations of detection site $(t)$ and group (treatment, year, and photoperiod). $\mathrm{A}^{\prime} *^{\prime \prime}$ indicated a multiplicative effect, a ' + ' indicates an additive effect, and a '.' indicates a common value fitted to all groups and reaches. A multiplicative model $(\mathrm{g} * \mathrm{t})$ of apparent survival (phi) was used in all models. $\mathrm{K}$ indicates the number of estimable parameters]

\begin{tabular}{lcccccc}
\hline \multicolumn{1}{c}{ Model } & \multicolumn{1}{c}{ AICc } & \multicolumn{1}{c}{$\begin{array}{c}\text { Delta } \\
\text { AlCc }\end{array}$} & $\begin{array}{c}\text { AlCc } \\
\text { Weights }\end{array}$ & $\begin{array}{c}\text { Model } \\
\text { Likelihood }\end{array}$ & K & Deviance \\
\hline$\{1 \mathrm{Phi}(\mathrm{g} * \mathrm{t}) \mathrm{p}(\mathrm{g} * \mathrm{t})\}$ & 14736.09 & 0.00 & 1.00 & 1.00 & 84 & 14567.04 \\
$\{2 \mathrm{Phi}(\mathrm{g} * \mathrm{t}) \mathrm{p}(\mathrm{g}+\mathrm{t})\}$ & 14759.35 & 23.26 & 0.00 & 0.00 & 84 & 14590.31 \\
$\{3 \mathrm{Phi}(\mathrm{g} * \mathrm{t}) \mathrm{p}(\mathrm{g})\}$ & 15908.43 & 1172.34 & 0.00 & 0.00 & 84 & 15739.38 \\
$\{4 \mathrm{Phi}(\mathrm{g} * \mathrm{t}) \mathrm{p}(\mathrm{t})\}$ & 16562.16 & 1826.07 & 0.00 & 0.00 & 57 & 16447.68 \\
$\{5 \mathrm{Phi}(\mathrm{g} * \mathrm{t}) \mathrm{p}()\}$. & 17414.50 & 2678.41 & 0.00 & 0.00 & 57 & 17300.02 \\
\hline
\end{tabular}




\section{Appendix 0. Summaries of Covariate Values of Juvenile Steelhead from Data Used in Studies at McNary Dam in 2004-2009.}

Table 01 - Summary statistics of turbine unit discharge (thousand $\mathrm{ft} 3 / \mathrm{s}$ ) during juvenile steelhead passage from data used in studies at McNary Dam in 2004-2009.

$[N$, number of observations; Min, minimum; Max, maximum; SD, standard deviation; SE, standard error $]$

\begin{tabular}{lcccccccc}
\hline & Year & \multicolumn{1}{c}{$\boldsymbol{N}$} & \multicolumn{1}{c}{ Min } & Max & Mean & Median & SD & SE \\
\hline Overall & 2004 & 47 & 10.50 & 16.60 & 12.69 & 12.00 & 1.66 & 0.24 \\
& 2005 & 57 & 7.90 & 16.30 & 10.69 & 10.70 & 1.54 & 0.20 \\
& 2006 & 79 & 8.33 & 12.94 & 11.97 & 12.12 & 0.89 & 0.10 \\
& 2007 & 48 & 8.13 & 12.28 & 10.72 & 11.17 & 1.40 & 0.20 \\
& 2008 & 66 & 8.31 & 12.30 & 10.40 & 10.18 & 1.25 & 0.15 \\
& 2009 & 54 & 8.65 & 12.56 & 11.32 & 11.97 & 1.12 & 0.15 \\
\hline \multirow{6}{*}{ Day } & Overall & 351 & 7.90 & 16.60 & 11.29 & 11.90 & 1.51 & 0.08 \\
& 2004 & 19 & 11.40 & 16.60 & 13.22 & 12.20 & 1.88 & 0.43 \\
& 2005 & 32 & 7.90 & 12.20 & 10.13 & 9.90 & 1.21 & 0.21 \\
& 2006 & 39 & 8.33 & 12.94 & 12.12 & 12.19 & 0.83 & 0.13 \\
& 2007 & 23 & 8.49 & 12.24 & 10.82 & 11.16 & 1.30 & 0.27 \\
& 2008 & 31 & 8.37 & 12.30 & 9.92 & 9.48 & 1.15 & 0.21 \\
Night & 2009 & 27 & 8.65 & 12.39 & 11.05 & 11.59 & 1.20 & 0.23 \\
\hline & 2004 & 28 & 10.50 & 16.40 & 12.33 & 12.00 & 1.41 & 0.27 \\
& 2005 & 25 & 7.90 & 16.30 & 11.40 & 12.00 & 1.66 & 0.33 \\
& 2006 & 40 & 8.80 & 12.94 & 11.82 & 12.06 & 0.92 & 0.15 \\
& 2007 & 25 & 8.13 & 12.28 & 10.62 & 11.23 & 1.51 & 0.30 \\
& 2008 & 35 & 8.31 & 12.18 & 10.83 & 11.29 & 1.19 & 0.20 \\
& 2009 & 27 & 9.34 & 12.56 & 11.59 & 12.05 & 0.98 & 0.19 \\
\hline
\end{tabular}


Table $\mathrm{O} 2$ - Summary statistics of head (ft) during juvenile steelhead passage from data used in studies at McNary Dam in 2004-2009.

[N, number of observations; Min, minimum; Max, maximum; SD, standard deviation; SE, standard error]

\begin{tabular}{lcccccccc}
\hline & Year & $\boldsymbol{N}$ & Min & Max & Mean & Median & SD & SE \\
\hline Overall & 2004 & 47 & 69.22 & 75.35 & 72.86 & 72.80 & 1.15 & 0.17 \\
& 2005 & 57 & 70.05 & 75.64 & 73.72 & 73.76 & 1.18 & 0.16 \\
& 2006 & 79 & 67.36 & 71.89 & 70.00 & 70.11 & 1.11 & 0.12 \\
& 2007 & 48 & 70.02 & 74.82 & 72.23 & 72.46 & 1.11 & 0.16 \\
& 2008 & 66 & 68.12 & 75.19 & 71.94 & 72.08 & 2.30 & 0.28 \\
& 2009 & 54 & 69.42 & 74.06 & 71.58 & 71.32 & 1.25 & 0.17 \\
& Overall & 351 & 67.36 & 75.64 & 71.90 & 71.98 & 1.89 & 0.10 \\
\hline Day & 2004 & 19 & 70.81 & 75.35 & 73.12 & 72.74 & 1.25 & 0.29 \\
& 2005 & 32 & 71.62 & 75.64 & 74.03 & 74.24 & 1.20 & 0.21 \\
& 2006 & 39 & 67.47 & 71.47 & 69.86 & 69.86 & 1.01 & 0.16 \\
& 2007 & 23 & 70.02 & 74.82 & 72.08 & 71.86 & 1.29 & 0.27 \\
& 2008 & 31 & 68.27 & 75.19 & 73.01 & 73.18 & 1.86 & 0.33 \\
& 2009 & 27 & 69.64 & 74.01 & 71.83 & 71.67 & 1.19 & 0.23 \\
\hline \multirow{6}{*}{ Night } & 2004 & 28 & 69.22 & 74.04 & 72.68 & 72.83 & 1.06 & 0.20 \\
& 2005 & 25 & 70.05 & 75.09 & 73.34 & 73.64 & 1.06 & 0.21 \\
& 2006 & 40 & 67.36 & 71.89 & 70.13 & 70.54 & 1.19 & 0.19 \\
& 2007 & 25 & 70.63 & 74.15 & 72.37 & 72.51 & 0.92 & 0.18 \\
& 2008 & 35 & 68.12 & 74.91 & 71.00 & 69.89 & 2.26 & 0.38 \\
& 2009 & 27 & 69.42 & 74.06 & 71.33 & 71.02 & 1.28 & 0.25 \\
\hline
\end{tabular}


Table 03 - Summary statistics of total project discharge (thousand $\mathrm{ft} 3 / \mathrm{s}$ ) during juvenile steelhead passage from data used in studies at McNary Dam in 2004-2009.

[ $N$, number of observations; Min, minimum; Max, maximum; SD, standard deviation; SE, standard error]

\begin{tabular}{lrrrrrrrr}
\hline & Year & $\boldsymbol{N}$ & Min & Max & Mean & Median & SD & SE \\
\hline Overall & 2004 & 746 & 130.40 & 318.60 & 190.74 & 172.10 & 44.24 & 1.62 \\
& 2005 & 57 & 90.90 & 347.90 & 189.69 & 172.70 & 54.88 & 7.27 \\
& 2006 & 79 & 248.99 & 396.37 & 329.67 & 342.01 & 40.98 & 4.61 \\
& 2007 & 48 & 171.95 & 288.34 & 245.99 & 253.14 & 29.87 & 4.31 \\
& 2008 & 785 & 157.03 & 418.52 & 267.59 & 260.99 & 79.21 & 2.83 \\
& 2009 & 785 & 141.43 & 356.09 & 263.88 & 262.87 & 50.68 & 1.81 \\
& Overall & 2500 & 90.90 & 418.52 & 243.26 & 235.92 & 70.28 & 1.41 \\
\hline Day & 2004 & 123 & 184.40 & 253.50 & 237.21 & 250.10 & 23.25 & 2.10 \\
& 2005 & 32 & 90.90 & 301.10 & 193.01 & 182.90 & 46.53 & 8.22 \\
& 2006 & 39 & 271.28 & 389.22 & 334.02 & 346.50 & 34.66 & 5.55 \\
& 2007 & 23 & 171.95 & 288.34 & 248.00 & 255.59 & 33.15 & 6.91 \\
& 2008 & 104 & 170.77 & 369.03 & 223.95 & 220.67 & 49.41 & 4.85 \\
& 2009 & 200 & 141.43 & 350.88 & 244.15 & 242.40 & 60.41 & 4.27 \\
\hline Night & 2004 & 623 & 130.40 & 318.60 & 181.57 & 163.50 & 41.55 & 1.66 \\
& 2005 & 25 & 92.80 & 347.90 & 185.43 & 158.00 & 64.80 & 12.96 \\
& 2006 & 40 & 248.99 & 396.37 & 325.43 & 310.03 & 46.39 & 7.33 \\
& 2007 & 25 & 177.23 & 283.38 & 244.14 & 248.09 & 27.08 & 5.42 \\
& 2008 & 681 & 157.03 & 418.52 & 274.25 & 267.49 & 80.79 & 3.10 \\
& 2009 & 585 & 177.02 & 356.09 & 270.62 & 268.91 & 45.01 & 1.86 \\
\hline
\end{tabular}


Table 04 - Summary statistics of spill percentage during juvenile steelhead passage from data used in studies at McNary Dam in 2004-2009.

[ $N$, number of observations; Min, minimum; Max, maximum; SD, standard deviation; SE, standard error $]$

\begin{tabular}{lrrrrrrrr}
\hline & Year & $\boldsymbol{N}$ & Min & Max & Mean & Median & SD & SE \\
\hline Overall & 2004 & 793 & 0.00 & 78.49 & 28.23 & 0.32 & 31.74 & 1.13 \\
& 2005 & 57 & 0.00 & 75.09 & 36.65 & 45.43 & 24.08 & 3.19 \\
& 2006 & 79 & 36.09 & 64.43 & 48.79 & 50.65 & 6.77 & 0.76 \\
& 2007 & 48 & 39.81 & 46.67 & 40.82 & 40.72 & 0.94 & 0.14 \\
& 2008 & 851 & 39.42 & 60.52 & 45.17 & 40.82 & 7.09 & 0.24 \\
& 2009 & 839 & 38.77 & 59.13 & 43.03 & 40.89 & 4.01 & 0.14 \\
& Overall & 2667 & 0.00 & 78.49 & 39.31 & 40.82 & 19.71 & 0.38 \\
\hline \multirow{6}{*}{ Day } & 2004 & 142 & 48.88 & 78.49 & 67.47 & 68.43 & 4.20 & 0.35 \\
& 2005 & 32 & 32.83 & 75.09 & 51.21 & 48.39 & 11.59 & 2.05 \\
& 2006 & 39 & 40.10 & 64.43 & 49.23 & 50.68 & 5.80 & 0.93 \\
& 2007 & 23 & 39.81 & 41.46 & 40.71 & 40.77 & 0.41 & 0.08 \\
& 2008 & 135 & 40.02 & 59.80 & 42.37 & 40.89 & 4.15 & 0.36 \\
& 2009 & 227 & 40.11 & 54.30 & 42.61 & 41.00 & 3.39 & 0.22 \\
\hline \multirow{6}{*}{ Night } & 2004 & 651 & 0.00 & 75.48 & 19.67 & 0.00 & 28.53 & 1.12 \\
& 2005 & 25 & 0.00 & 55.71 & 18.02 & 0.00 & 23.13 & 4.63 \\
& 2006 & 40 & 36.09 & 61.91 & 48.36 & 50.60 & 7.65 & 1.21 \\
& 2007 & 25 & 39.87 & 46.67 & 40.93 & 40.69 & 1.24 & 0.25 \\
& 2008 & 716 & 39.42 & 60.52 & 45.69 & 40.79 & 7.40 & 0.28 \\
& 2009 & 612 & 38.77 & 59.13 & 43.18 & 40.85 & 4.20 & 0.17 \\
\hline
\end{tabular}


Table 05 - Summary statistics of tag burden (percent) during juvenile steelhead passage from data used in studies at McNary Dam in 2004-2009.

[ $N$, number of observations; Min, minimum; Max, maximum; SD, standard deviation; SE, standard error ]

\begin{tabular}{lcccccccc}
\hline & Year & \multicolumn{1}{c}{$\boldsymbol{N}$} & Min & Max & Mean & Median & SD & SE \\
\hline Overall & 2004 & 793 & 0.76 & 6.41 & 2.19 & 2.08 & 0.73 & 0.03 \\
& 2005 & 57 & 0.85 & 4.96 & 1.62 & 1.49 & 0.63 & 0.08 \\
& 2006 & 79 & 0.66 & 4.84 & 2.22 & 2.12 & 0.82 & 0.09 \\
& 2007 & 48 & 0.94 & 4.00 & 2.04 & 1.95 & 0.73 & 0.10 \\
& 2008 & 851 & 0.60 & 5.60 & 2.01 & 1.95 & 0.64 & 0.02 \\
& 2009 & 839 & 0.69 & 4.63 & 1.73 & 1.67 & 0.53 & 0.02 \\
& Overall & 2667 & 0.60 & 6.41 & 1.98 & 1.89 & 0.67 & 0.01 \\
\hline \multirow{6}{*}{ Day } & 2004 & 142 & 0.95 & 4.71 & 2.15 & 2.05 & 0.65 & 0.05 \\
& 2005 & 32 & 1.01 & 2.90 & 1.62 & 1.51 & 0.46 & 0.08 \\
& 2006 & 39 & 0.66 & 4.66 & 2.03 & 1.93 & 0.70 & 0.11 \\
& 2007 & 23 & 0.94 & 3.39 & 2.02 & 1.87 & 0.74 & 0.15 \\
& 2008 & 135 & 0.95 & 4.90 & 1.91 & 1.84 & 0.56 & 0.05 \\
& 2009 & 227 & 0.72 & 4.63 & 1.74 & 1.68 & 0.56 & 0.04 \\
\hline \multirow{6}{*}{ Night } & 2004 & 651 & 0.76 & 6.41 & 2.20 & 2.09 & 0.74 & 0.03 \\
& 2005 & 25 & 0.85 & 4.96 & 1.63 & 1.41 & 0.81 & 0.16 \\
& 2006 & 40 & 1.04 & 4.84 & 2.40 & 2.34 & 0.89 & 0.14 \\
& 2007 & 25 & 1.17 & 4.00 & 2.07 & 1.97 & 0.73 & 0.15 \\
& 2008 & 716 & 0.60 & 5.60 & 2.03 & 1.98 & 0.65 & 0.02 \\
& 2009 & 612 & 0.69 & 4.20 & 1.73 & 1.66 & 0.53 & 0.02 \\
\hline
\end{tabular}


Table 06 - Summary statistics of water temperature during juvenile steelhead passage from data used in studies at McNary Dam in 2004-2009.

[ $N$, number of observations; Min, minimum; Max, maximum; SD, standard deviation; SE, standard error]

\begin{tabular}{|c|c|c|c|c|c|c|c|c|}
\hline & Year & $N$ & Min & Max & Mean & Median & SD & SE \\
\hline \multirow[t]{7}{*}{ Overall } & 2004 & 793 & 10.33 & 14.00 & 12.64 & 12.83 & 0.80 & 0.03 \\
\hline & 2005 & 57 & 10.06 & 14.94 & 11.83 & 11.39 & 1.08 & 0.14 \\
\hline & 2006 & 79 & 10.00 & 14.50 & 12.39 & 12.40 & 1.41 & 0.16 \\
\hline & 2007 & 48 & 9.33 & 15.67 & 12.77 & 13.03 & 1.98 & 0.29 \\
\hline & 2008 & 851 & 8.28 & 13.56 & 10.74 & 10.72 & 1.59 & 0.05 \\
\hline & 2009 & 839 & 8.11 & 15.00 & 10.98 & 10.72 & 1.92 & 0.07 \\
\hline & Overall & 2667 & 8.11 & 15.67 & 11.49 & 11.72 & 1.74 & 0.03 \\
\hline \multirow[t]{6}{*}{ Day } & 2004 & 142 & 10.67 & 13.00 & 12.30 & 12.83 & 0.76 & 0.06 \\
\hline & 2005 & 32 & 10.06 & 14.33 & 11.78 & 11.61 & 0.90 & 0.16 \\
\hline & 2006 & 39 & 10.10 & 14.50 & 12.53 & 12.40 & 1.41 & 0.23 \\
\hline & 2007 & 23 & 10.44 & 15.28 & 12.74 & 12.39 & 1.80 & 0.38 \\
\hline & 2008 & 135 & 8.44 & 12.67 & 9.73 & 9.50 & 1.18 & 0.10 \\
\hline & 2009 & 227 & 8.33 & 14.94 & 10.85 & 10.33 & 1.94 & 0.13 \\
\hline \multirow[t]{6}{*}{ Night } & 2004 & 651 & 10.33 & 14.00 & 12.71 & 12.89 & 0.79 & 0.03 \\
\hline & 2005 & 25 & 10.11 & 14.94 & 11.89 & 11.39 & 1.30 & 0.26 \\
\hline & 2006 & 40 & 10.00 & 14.50 & 12.26 & 12.40 & 1.41 & 0.22 \\
\hline & 2007 & 25 & 9.33 & 15.67 & 12.80 & 13.28 & 2.17 & 0.43 \\
\hline & 2008 & 716 & 8.28 & 13.56 & 10.93 & 11.33 & 1.59 & 0.06 \\
\hline & 2009 & 612 & 8.11 & 15.00 & 11.02 & 10.89 & 1.91 & 0.08 \\
\hline
\end{tabular}




\section{Appendix P. Capture History Summary of Juvenile Steelhead from Data Used in Studies at McNary Dam in 2004-2005 and 2009.}

[Occ. represents the Occasion number after release. $R(i)$ represents numbers released and $j=2$ and 3 indicate the released number detected at each downstream site]

\begin{tabular}{crrrr}
\hline \multicolumn{5}{c}{ Group 1 control day 2004} \\
Occ. & R(i) & $\mathrm{j}=2$ & $\mathrm{j}=3$ & Total \\
\hline 1 & 623 & 397 & 142 & 539 \\
2 & 397 & & 334 & 334 \\
\\
Group 2 & control day 2009 \\
Occ. & R(i) & $\mathrm{j}=2$ & $\mathrm{j}=3$ & Total \\
\hline 1 & 585 & 548 & 2 & 550 \\
2 & 548 & & 517 & 517
\end{tabular}

Group 3 control night 2004

$\begin{array}{rrrrr}\text { Occ. } & R(i) & j=2 & j=3 & \text { Total } \\ 1 & 123 & 91 & 14 & 105 \\ 2 & 91 & & 84 & 84\end{array}$

Group 4 control night 2009

$\begin{array}{rrrrr}\text { Occ. } & R(i) & j=2 & j=3 & \text { Total } \\ 1 & 200 & 185 & 0 & 185 \\ 2 & 185 & & 168 & 168\end{array}$

Group 5 turbine day 2004

\begin{tabular}{rrrrr} 
Occ. & $R(i)$ & $j=2$ & $j=3$ & Total \\
1 & 28 & 14 & 5 & 19 \\
2 & 14 & & 13 & 13 \\
\hline
\end{tabular}

Group 6 turbine day 2005

\begin{tabular}{rrrrr} 
Occ. & $R(i)$ & $j=2$ & $j=3$ & Total \\
\hline 1 & 25 & 14 & 4 & 18 \\
2 & 14 & & 12 & 12
\end{tabular}

Group 7 turbine day 2009

\begin{tabular}{rrrrr} 
Occ. & $\mathrm{R}(\mathrm{i})$ & $\mathrm{j}=2$ & $\mathrm{j}=3$ & Total \\
\hline 1 & 27 & 19 & 0 & 19 \\
2 & 19 & & 19 & 19
\end{tabular}

Group 8 turbine night 2004

\begin{tabular}{rrrrr} 
Occ. & $\mathrm{R}(\mathrm{i})$ & $\mathrm{j}=2$ & $\mathrm{j}=3$ & Total \\
\hline 1 & 19 & 14 & 2 & 16 \\
2 & 14 & & 11 & 11
\end{tabular}

Group 9 turbine night 2005

\begin{tabular}{crrrr} 
Occ. & $\mathrm{R}(\mathrm{i})$ & $\mathrm{j}=2$ & $\mathrm{j}=3$ & Total \\
\hline 1 & 32 & 21 & 3 & 24 \\
2 & 21 & & 21 & 21
\end{tabular}

Group 10 turbine night 2009

\begin{tabular}{rrrrr} 
Occ. & $R(i)$ & $j=2$ & $j=3$ & Total \\
1 & 27 & 23 & 0 & 23 \\
2 & 23 & & 23 & 23 \\
\hline
\end{tabular}




\section{Appendix Q. Results of Correlation Analyses of Juvenile Steelhead from Data Used in Studies at McNary Dam in 2004-2005 and 2009.}

Table Q1. Table of correlation indices of data from juvenile steelhead from the turbine group from data used in studies at McNary Dam in 2004, 2005, and 2009.

[Pearson correlation coefficients are listed above the probabilities of obtaining a greater value under the hypothesis that $\mathrm{Rho}=0$. Sample size is $158 ;<$, less than; see table 2 for variable name definitions]

\begin{tabular}{|c|c|c|c|c|c|c|c|c|c|}
\hline & TOTQ & PER_SPI & HEAD & TURQ & TURBLOC & РНОTO & TEMP & WEIGHT & $\begin{array}{c}\text { TAG } \\
\text { BURDEN }\end{array}$ \\
\hline \multirow[t]{2}{*}{ TOTQ } & 1.0000 & 0.4610 & -0.8358 & 0.2063 & 0.0956 & 0.0662 & 0.1317 & 0.0836 & -0.0137 \\
\hline & & $<0.0001$ & $<0.0001$ & 0.0093 & 0.2322 & 0.4088 & 0.0991 & 0.2961 & 0.8645 \\
\hline \multirow[t]{2}{*}{ PER_SPI } & & 1.0000 & -0.0449 & -0.0582 & -0.0929 & 0.6055 & -0.0355 & -0.0871 & -0.0293 \\
\hline & & & 0.5755 & 0.4675 & 0.2455 & $<0.0001$ & 0.6576 & 0.2763 & 0.7147 \\
\hline \multirow[t]{2}{*}{ HEAD } & & & 1.0000 & -0.2839 & -0.1596 & 0.2075 & -0.0850 & -0.1414 & -0.0441 \\
\hline & & & & 0.0003 & 0.0451 & 0.0089 & 0.2882 & 0.0764 & 0.5825 \\
\hline \multirow[t]{2}{*}{ TURQ } & & & & 1.0000 & -0.0618 & -0.1779 & 0.3206 & -0.0164 & 0.2995 \\
\hline & & & & & 0.4407 & 0.0253 & $<0.0001$ & 0.8381 & 0.0001 \\
\hline \multirow[t]{2}{*}{ TURBLOC } & & & & & 1.0000 & -0.0439 & -0.2326 & -0.0956 & 0.0646 \\
\hline & & & & & & 0.5838 & 0.0033 & 0.2324 & 0.4197 \\
\hline \multirow[t]{2}{*}{ РНОTO } & & & & & & 1.0000 & -0.2778 & -0.0658 & -0.0832 \\
\hline & & & & & & & 0.0004 & 0.4117 & 0.0298 \\
\hline \multirow[t]{2}{*}{ TEMP } & & & & & & & 1.0000 & 0.0474 & 0.1779 \\
\hline & & & & & & & & 0.5546 & 0.0254 \\
\hline \multirow[t]{2}{*}{ WEIGHT } & & & & & & & & 1.0000 & -0.7478 \\
\hline & & & & & & & & & $<0.0001$ \\
\hline
\end{tabular}


Table Q2. Table of correlation indices of data from juvenile steelhead from the control group from data used in studies at McNary Dam in 2004, 2005, and 2009.

[Pearson correlation coefficients are listed above the probabilities of obtaining a greater value under the hypothesis that $\mathrm{Rho}=0$. Sample size is 1,$531 ;<$, less than; see table 2 for variable name definitions ]

\begin{tabular}{|c|c|c|c|c|c|c|}
\hline & TOTQ & PER_SPI & РНОTO & TEMP & WEIGHT & $\begin{array}{c}\text { TAG } \\
\text { BURDEN }\end{array}$ \\
\hline \multirow[t]{2}{*}{ TOTQ } & 1.0000 & 0.6132 & 0.1143 & 0.0466 & -0.0667 & -0.1793 \\
\hline & & $<0.0001$ & $<0.0001$ & 0.0683 & 0.0090 & $<0.0001$ \\
\hline \multirow[t]{2}{*}{ PER_SPI } & & 1.0000 & 0.3654 & -0.1099 & -0.0412 & -0.1102 \\
\hline & & & $<0.0001$ & $<0.0001$ & 0.1070 & $<0.0001$ \\
\hline \multirow[t]{2}{*}{ РНОТО } & & & 1.0000 & -0.0917 & 0.0011 & -0.0453 \\
\hline & & & & 0.0003 & 0.9651 & 0.0767 \\
\hline \multirow[t]{2}{*}{ TEMP } & & & & 1.0000 & 0.0512 & 0.2124 \\
\hline & & & & & 0.0451 & $<0.0001$ \\
\hline \multirow[t]{2}{*}{ WEIGHT } & & & & & 1.0000 & -0.8071 \\
\hline & & & & & & $<0.0001$ \\
\hline
\end{tabular}




\section{Appendix R. Model Summary from Analyses of Recapture Probabilities ( $p$ ) of Juvenile Steelhead from Data Used in Studies at McNary Dam in 2004-2005 and 2009.}

[Models of $\mathrm{p}$ include those in which values can vary in various combinations of detection site ( $\mathrm{t}$ ) and group (treatment, year, and photoperiod). $\mathrm{A}^{\prime * \prime}$ indicated a multiplicative effect, a '+' indicates an additive effect, and a '.' indicates a common value fitted to all groups and reaches. A multiplicative model $(\mathrm{g} * \mathrm{t})$ of apparent survival (phi) was used in all models. $\mathrm{K}$ indicates the number of estimable parameters]

\begin{tabular}{|c|c|c|c|c|c|c|}
\hline Model & $\mathrm{AlCc}$ & $\begin{array}{l}\text { Delta } \\
\text { AlCc }\end{array}$ & $\begin{array}{c}\text { AlCc } \\
\text { Weights }\end{array}$ & $\begin{array}{c}\text { Model } \\
\text { Likelihoo } \\
\text { d } \\
\end{array}$ & $\mathrm{K}$ & Deviance \\
\hline$\left\{1\right.$ Phi $\left(g^{*} \mathrm{t}\right), \mathrm{p}(\mathrm{g} * \mathrm{t}\}$ & 2773.45 & 0.00 & 1.00 & 1.00 & 25 & 2723.02 \\
\hline$\{2 \operatorname{Phi}(\mathrm{g} * \mathrm{t}), \mathrm{p}(\mathrm{g}+\mathrm{t}\}$ & 2830.40 & 56.95 & 0.00 & 0.00 & 25 & 2779.97 \\
\hline$\{3$ Phi $(\mathrm{g} * \mathrm{t}), \mathrm{p}(\mathrm{g})\}$ & 2865.30 & 91.85 & 0.00 & 0.00 & 25 & 2814.87 \\
\hline$\{4 \operatorname{Phi}(\mathrm{g} * \mathrm{t}), \mathrm{p}(\mathrm{t})\}$ & 2994.67 & 221.22 & 0.00 & 0.00 & 16 & 2962.49 \\
\hline$\{5 \operatorname{Phi}(\mathrm{g} * \mathrm{t}), \mathrm{p}()\}$. & 3011.59 & 238.14 & 0.00 & 0.00 & 16 & 2979.41 \\
\hline
\end{tabular}




\section{Appendix S. Model-selection Results from Radio- and Acoustic-tagged Juvenile Steelhead from Data Used in Studies at McNary Dam in 2004-2005 and 2009.}

[Presence of a factor in a model is indicated by an ' $\mathrm{x}$ ' in the column for that factor. Model 1 was a global model including all group covariates and their interactions (g) as well as all individual covariates and interactions listed. Distance to the first downriver gate (gated) was only used when year was present in the model. All models shared a common year*reach model of recapture probability. K indicates the number of parameters.]

\begin{tabular}{|c|c|c|c|c|c|c|c|c|c|c|c|c|c|c|c|c|c|c|c|c|c|c|c|c|c|c|c|c|}
\hline \multirow[b]{3}{*}{$\begin{array}{c}\text { Model } \\
\text { Numbe } \\
r\end{array}$} & \multirow{2}{*}{\multicolumn{8}{|c|}{ Group Covariates }} & \multicolumn{17}{|c|}{ Individual Covariates } & \multirow{2}{*}{\multicolumn{3}{|c|}{ Model Selection Results }} \\
\hline & & & & & & & & & \multicolumn{8}{|c|}{ Biological } & \multicolumn{9}{|c|}{ Operational } & & & \\
\hline & $\pi$ & 톤 & 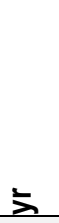 & $\begin{array}{l}\text { 옹 } \\
\text { 응 }\end{array}$ & 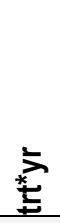 & $\begin{array}{l}\text { 옹 } \\
\text { 응 } \\
\text { 논 }\end{array}$ & $\begin{array}{l}\text { 옹 } \\
\frac{0}{2} \\
\text { 눈 }\end{array}$ & 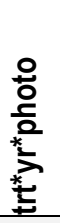 & 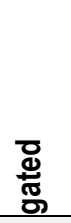 & $\xi$ & 응 & $\begin{array}{l}\text { 음 } \\
\text { ț } \\
\text { ț } \\
\end{array}$ & 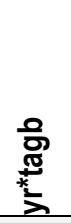 & ह을 & 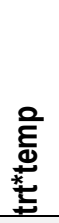 & $\begin{array}{l}\text { 을 } \\
\frac{1}{d} \\
\frac{*}{\lambda} \\
\end{array}$ & 은 & 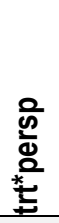 & 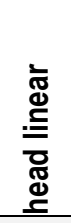 & 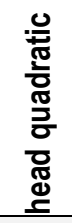 & 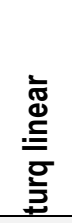 & 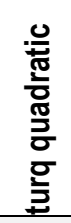 & 은 & 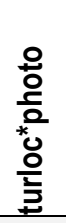 & 훙 & $\mathrm{AlCc}$ & $\mathrm{K}$ & $\begin{array}{c}\text { Devianc } \\
\mathrm{e} \\
\end{array}$ \\
\hline 1 & $\mathrm{x}$ & $\mathrm{x}$ & $\mathrm{x}$ & $\mathrm{x}$ & $\mathrm{x}$ & $\mathrm{x}$ & $\mathrm{x}$ & $\mathrm{x}$ & & & $\mathrm{x}$ & $\mathrm{x}$ & $\mathrm{x}$ & $\mathrm{x}$ & $\mathrm{x}$ & $\mathrm{x}$ & $\mathrm{x}$ & $\mathrm{x}$ & $\mathrm{x}$ & & $\mathrm{x}$ & & $\mathrm{x}$ & $\mathrm{x}$ & $\mathrm{x}$ & 2790. & 38 & 2713.0 \\
\hline 2 & $\mathrm{x}$ & $\mathrm{x}$ & $\mathrm{x}$ & $\mathrm{x}$ & $\mathrm{x}$ & $\mathrm{x}$ & $\mathrm{x}$ & $\mathrm{x}$ & & & $\mathrm{x}$ & $\mathrm{x}$ & & $\mathrm{x}$ & $\mathrm{x}$ & $\mathrm{x}$ & $\mathrm{x}$ & $\mathrm{x}$ & $\mathrm{x}$ & & $\mathrm{x}$ & & $\mathrm{x}$ & $\mathrm{x}$ & $\mathrm{x}$ & 2792. & 36 & 2719.5 \\
\hline 3 & $\mathrm{x}$ & $\mathrm{x}$ & $\mathrm{x}$ & $\mathrm{X}$ & $\mathrm{x}$ & $\mathrm{x}$ & $\mathrm{x}$ & $\mathrm{x}$ & & & $\mathrm{x}$ & $\mathrm{x}$ & $\mathrm{x}$ & $\mathrm{x}$ & $\mathrm{x}$ & & $\mathrm{x}$ & $\mathrm{x}$ & $\mathrm{x}$ & & $\mathrm{x}$ & & $\mathrm{x}$ & $\mathrm{x}$ & $\mathrm{x}$ & 2800 & 36 & 2728.0 \\
\hline 4 & & $\mathrm{x}$ & & $\mathrm{x}$ & & $\mathrm{x}$ & & & $\mathrm{x}$ & & $\mathrm{x}$ & $\mathrm{x}$ & $\mathrm{x}$ & $\mathrm{x}$ & $\mathrm{x}$ & $\mathrm{x}$ & $\mathrm{x}$ & $\mathrm{x}$ & $\mathrm{x}$ & & $\mathrm{x}$ & & $\mathrm{x}$ & $\mathrm{x}$ & $\mathrm{x}$ & 2781. & 33 & 2715.2 \\
\hline 5 & & $\mathrm{x}$ & & $\mathrm{X}$ & & $\mathrm{x}$ & & & $\mathrm{x}$ & & $\mathrm{X}$ & $\mathrm{x}$ & $\mathrm{x}$ & $\mathrm{x}$ & $\mathrm{x}$ & $\mathrm{x}$ & $\mathrm{x}$ & $\mathrm{x}$ & $\mathrm{x}$ & & $\mathrm{x}$ & & $\mathrm{x}$ & & $\mathrm{x}$ & 2779. & 32 & 2715.2 \\
\hline 6 & & $\mathrm{x}$ & & $\mathrm{x}$ & & & & & $\mathrm{x}$ & & $\mathrm{x}$ & $\mathrm{x}$ & $\mathrm{x}$ & $\mathrm{x}$ & $\mathrm{x}$ & $\mathrm{x}$ & $\mathrm{x}$ & $\mathrm{x}$ & $\mathrm{x}$ & & $\mathrm{x}$ & & $\mathrm{x}$ & & $\mathrm{x}$ & 2779 . & 31 & 2716.7 \\
\hline 7 & & $\mathrm{x}$ & & $\mathrm{X}$ & & & & & $\mathrm{x}$ & & $\mathrm{x}$ & $\mathrm{X}$ & $\mathrm{x}$ & $\mathrm{x}$ & & $\mathrm{x}$ & $\mathrm{x}$ & $\mathrm{X}$ & $\mathrm{x}$ & & $\mathrm{x}$ & & $\mathrm{x}$ & & $\mathrm{x}$ & 2778 & 30 & 2717.7 \\
\hline 8 & & $\mathrm{x}$ & & & & & & & $\mathrm{x}$ & & $\mathrm{x}$ & $\mathrm{x}$ & $\mathrm{x}$ & $\mathrm{x}$ & & $\mathrm{x}$ & $\mathrm{x}$ & $\mathrm{x}$ & $\mathrm{x}$ & & $\mathrm{x}$ & & $\mathrm{x}$ & & $\mathrm{x}$ & 2776 . & 29 & 2717.7 \\
\hline 9 & & $\mathrm{x}$ & & & & & & & $\mathrm{x}$ & & $\mathrm{X}$ & $\mathrm{x}$ & $\mathrm{x}$ & & & $\mathrm{x}$ & $\mathrm{x}$ & $\mathrm{x}$ & $\mathrm{x}$ & & $\mathrm{x}$ & & $\mathrm{x}$ & & $\mathrm{x}$ & 2774. & 28 & 2717.7 \\
\hline 10 & & $\mathrm{x}$ & & & & & & & $\mathrm{x}$ & & $\mathrm{x}$ & $\mathrm{x}$ & $\mathrm{x}$ & & & $\mathrm{x}$ & $\mathrm{x}$ & & $\mathrm{x}$ & & $\mathrm{x}$ & & $\mathrm{x}$ & & $\mathrm{x}$ & 2776 . & 27 & 2722.2 \\
\hline 11 & & $\mathrm{x}$ & & & & & & & $\mathrm{x}$ & & $\mathrm{X}$ & $\mathrm{X}$ & $\mathrm{x}$ & & & $\mathrm{x}$ & $\mathrm{x}$ & $\mathrm{x}$ & $\mathrm{x}$ & & $\mathrm{x}$ & & $\mathrm{x}$ & & & 2774 . & 27 & 2720.0 \\
\hline 12 & & $\mathrm{x}$ & & & & & & & $\mathrm{x}$ & & $\mathrm{X}$ & $\mathrm{X}$ & $\mathrm{x}$ & & & $\mathrm{X}$ & & $\mathrm{X}$ & $\mathrm{x}$ & & $\mathrm{x}$ & & $\mathrm{x}$ & & $\mathrm{x}$ & 2778 & 27 & 2724.1 \\
\hline 13 & & $\mathrm{x}$ & & & & & & & $\mathrm{x}$ & & $\mathrm{x}$ & $\mathrm{X}$ & $\mathrm{x}$ & & & $\mathrm{x}$ & $\mathrm{x}$ & $\mathrm{x}$ & $\mathrm{x}$ & & $\mathrm{x}$ & & & & $\mathrm{x}$ & 2773. & 27 & 2719.3 \\
\hline $14 \mathrm{a}$ & & $\mathrm{x}$ & & & & & & & $\mathrm{x}$ & & $\mathrm{X}$ & $\mathrm{X}$ & $\mathrm{x}$ & & & $\mathrm{x}$ & $\mathrm{x}$ & $\mathrm{x}$ & & & $\mathrm{x}$ & & & & $\mathrm{x}$ & 2772 . & 26 & 2719.7 \\
\hline $14 b$ & & $\mathrm{x}$ & & & & & & & $\mathrm{x}$ & & $\mathrm{X}$ & $\mathrm{X}$ & $\mathrm{x}$ & & & $\mathrm{x}$ & $\mathrm{x}$ & $\mathrm{x}$ & & $\mathrm{x}$ & $x$ & & & & $\mathrm{x}$ & 2775 . & 28 & 2718.9 \\
\hline $15 \mathrm{a}$ & & $\mathrm{x}$ & & & & & & & $\mathrm{x}$ & & $\mathrm{x}$ & $\mathrm{X}$ & $\mathrm{x}$ & & & $\mathrm{x}$ & $\mathrm{x}$ & $\mathrm{x}$ & & & & & & & $\mathrm{x}$ & 2770 & 25 & 2719.7 \\
\hline $15 b$ & & $\mathrm{x}$ & & & & & & & $\mathrm{x}$ & & $\mathrm{x}$ & $\mathrm{x}$ & $\mathrm{x}$ & & & $\mathrm{x}$ & $\mathrm{x}$ & $\mathrm{x}$ & & & & $\mathrm{x}$ & & & $\mathrm{x}$ & 2773 & 27 & 2719.4 \\
\hline 16 & & $\mathrm{x}$ & & & & & & & $\mathrm{x}$ & & $\mathrm{x}$ & & $\mathrm{x}$ & & & $\mathrm{x}$ & $\mathrm{x}$ & $\mathrm{x}$ & & & & & & & $\mathrm{x}$ & 2768 & 24 & 2720.4 \\
\hline $17 *$ & & $\mathrm{x}$ & & & & & & & & & $\mathrm{x}$ & & $\mathrm{x}$ & & & $\mathrm{x}$ & $\mathrm{x}$ & $\mathrm{x}$ & & & & & & & $\mathrm{x}$ & 2766. & 23 & 2720.4 \\
\hline 18 & & $\mathrm{x}$ & & & & & & & & & & & $\mathrm{x}$ & & & $\mathrm{x}$ & $\mathrm{x}$ & $\mathrm{x}$ & & & & & & & $\mathrm{x}$ & 2767. & 22 & 2722.6 \\
\hline 19 & & $\mathrm{x}$ & & & & & & & & $\mathrm{x}$ & & & $\mathrm{x}$ & & & $\mathrm{x}$ & $\mathrm{x}$ & $\mathrm{x}$ & & & & & & & $\mathrm{x}$ & 2765. & 23 & 2719.5 \\
\hline
\end{tabular}




\section{Appendix T. Beta (Slope) Coefficients of Estimable Survival Parameters of Juvenile Steelhead from Data Used in Studies at McNary Dam in 2004-2005 and 2009.}

[The data are from model 17 in appendix S]

\begin{tabular}{lrrrr}
\hline & & Standard & \multicolumn{2}{c}{$95 \%$ Confidence } \\
\cline { 4 - 5 } \multicolumn{1}{c}{ Parameter } & Beta & Error & Lower & Upper \\
\hline intercept & 2.38540 & 0.56300 & 1.28191 & 3.48889 \\
treatment & -1.09401 & 0.64970 & -2.36741 & 0.17940 \\
tag burden & -0.23449 & 0.15202 & -0.53246 & 0.06348 \\
totq & 0.00427 & 0.00273 & -0.00108 & 0.00962 \\
persp & -0.01389 & 0.00563 & -0.02492 & -0.00286 \\
persp*trt & 0.02231 & 0.01025 & 0.00222 & 0.04240 \\
temp*2009 & -0.01401 & 0.05052 & -0.11303 & 0.08500 \\
temp*2005 & -0.06593 & 0.08709 & -0.23662 & 0.10476 \\
tag burden*2009 & 0.18442 & 0.25036 & -0.30629 & 0.67512 \\
tag burden*2005 & 0.40273 & 0.56854 & -0.71161 & 1.51706 \\
\hline
\end{tabular}




\section{Appendix U. Capture History Summary of Juvenile Steelhead from Data Used in Studies at McNary Dam in 2004-2005 and 2009.}

[Occ. represents the Occasion number after release. $R(i)$ represents numbers released and $j=2$ and 3 indicate the released number detected at each downstream site]

\begin{tabular}{ccccc}
\hline \multicolumn{6}{c}{ Group 1 control day 2004} \\
Occ. & R(i) & $\mathrm{j}=2$ & $\mathrm{j}=3$ & Total \\
\hline 1 & 623 & 397 & 142 & 539 \\
2 & 397 & & 334 & 334 \\
\multicolumn{6}{c}{ Group 2} & control day 2008 \\
Occ. & R(i) & $\mathrm{j}=2$ & $\mathrm{j}=3$ & Total \\
\hline 1 & 681 & 428 & 215 & 643 \\
2 & 428 & & 399 & 399
\end{tabular}

Group 3 control day 2009

\begin{tabular}{rrrrr} 
Occ. & $R(i)$ & $j=2$ & $j=3$ & Total \\
\hline 1 & 585 & 548 & 2 & 550 \\
2 & 548 & & 517 & 517
\end{tabular}

Group 4 control night 2004

\begin{tabular}{rrrrr} 
Occ. & R(i) & $\mathrm{j}=2$ & $\mathrm{j}=3$ & Total \\
\hline 1 & 123 & 91 & 14 & 105 \\
2 & 91 & & 84 & 84
\end{tabular}

Group 5 control night 2008

\begin{tabular}{rrrrr} 
Occ. & $R(i)$ & $j=2$ & $j=3$ & Total \\
\hline 1 & 104 & 67 & 28 & 95 \\
2 & 67 & & 62 & 62
\end{tabular}

Group 6 control night 2009

\begin{tabular}{rrrrr} 
Occ. & R(i) & $\mathrm{j}=2$ & $\mathrm{j}=3$ & Total \\
\hline 1 & 200 & 185 & 0 & 185 \\
2 & 185 & & 168 & 168
\end{tabular}

Group 7 turbine day 2004

\begin{tabular}{rrrrr} 
Occ. & $R(i)$ & $j=2$ & $j=3$ & Total \\
\hline 1 & 28 & 14 & 5 & 19 \\
2 & 14 & & 13 & 13
\end{tabular}

Group 8 turbine day 2005

$\begin{array}{rrrrr}\text { Occ. } & R(\mathrm{i}) & \mathrm{j}=2 & \mathrm{j}=3 & \text { Total } \\ 1 & 25 & 14 & 4 & 18 \\ 2 & 14 & & 12 & 12\end{array}$

Group 9 turbine day 2006

$\begin{array}{crrrr}\text { Occ. } & R(i) & j=2 & j=3 & \text { Total } \\ 1 & 40 & 23 & 8 & 31 \\ 2 & 23 & & 17 & 17\end{array}$

Group 10 turbine day 2007

\begin{tabular}{rrrrr} 
Occ. & $R(i)$ & $j=2$ & $j=3$ & Total \\
\hline 1 & 25 & 6 & 9 & 15 \\
2 & 6 & & 5 & 5
\end{tabular}

Group 11 turbine day 2008

$\begin{array}{ccccc}\text { Occ. } & R(i) & j=2 & j=3 & \text { Total } \\ 1 & 35 & 15 & 6 & 21 \\ 2 & 15 & & 14 & 14\end{array}$

Group 12 turbine day 2009

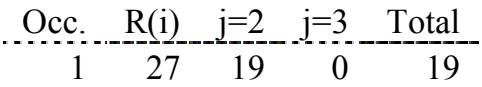

Group 13 turbine night 2004

\begin{tabular}{ccccc} 
Occ. & $R(\mathrm{i})$ & $\mathrm{j}=2$ & $\mathrm{j}=3$ & Total \\
\hline 1 & 19 & 14 & 2 & 16
\end{tabular}

$\begin{array}{llll}2 & 14 & 11 & 11\end{array}$

Group 14 turbine night 2005

$\begin{array}{ccccc}\text { Occ. } & R(i) & j=2 & j=3 & \text { Total } \\ 1 & 32 & 21 & 3 & 24\end{array}$

$\begin{array}{llll}2 & 21 & 21 & 21\end{array}$

Group 15 turbine night 2006

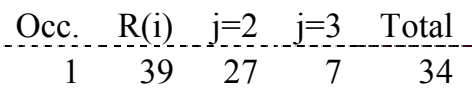

$\begin{array}{llll}2 & 27 & 23 & 23\end{array}$

Group 16 turbine night 2007

\begin{tabular}{ccccc} 
Occ. & $R(i)$ & $j=2$ & $j=3$ & Total \\
\hline 1 & 23 & 4 & 12 & 16
\end{tabular}

Group 17 turbine night 2008

\begin{tabular}{ccccc} 
Occ. & R(i) & $\mathrm{j}=2$ & $\mathrm{j}=3$ & Total \\
\hline 1 & 31 & 13 & 14 & 27 \\
2 & 13 & & 12 & 12
\end{tabular}

Group 18 turbine night 2009

$\begin{array}{ccccc}\text { Occ. } & R(i) & j=2 & j=3 & \text { Total } \\ 1 & 27 & 23 & 0 & 23\end{array}$ 


\section{Appendix V. Model Summary from Analyses of Recapture Probabilities (p) of Juvenile Steelhead from Data Used in Studies at McNary Dam in 2004-2005 and 2009.}

[Models of $\mathrm{p}$ include those in which values can vary in various combinations of detection site ( $\mathrm{t}$ ) and group (treatment, year, and photoperiod). $\mathrm{A}^{\prime}{ }^{\prime}$ ' indicated a multiplicative effect, a '+' indicates an additive effect, and a '.' indicates a common value fitted to all groups and reaches. A multiplicative model $(\mathrm{g} * \mathrm{t})$ of apparent survival (phi) was used in all models. $\mathrm{K}$ indicates the number of estimable parameters]

\begin{tabular}{lcccccc}
\hline \multicolumn{1}{c}{ Model } & AlCc & Delta AICc & $\begin{array}{c}\text { AlCc } \\
\text { Weights }\end{array}$ & $\begin{array}{c}\text { Model } \\
\text { Likelihood }\end{array}$ & K & Deviance \\
\hline$\{1$ Phi $(\mathrm{g} * \mathrm{t}), \mathrm{p}(\mathrm{g} * \mathrm{t})\}$ & 4799.74 & 0.00 & 1.00 & 1.00 & 47 & 4704.74 \\
$\{2 \mathrm{Phi}(\mathrm{g} * \mathrm{t}), \mathrm{p}(\mathrm{g}+\mathrm{t})\}$ & 4915.38 & 115.64 & 0.00 & 0.00 & 47 & 4820.38 \\
$\{3 \mathrm{Phi}(\mathrm{g} * \mathrm{t}), \mathrm{p}(\mathrm{g})\}$ & 5071.73 & 271.99 & 0.00 & 0.00 & 47 & 4976.74 \\
$\{4 \mathrm{Phi}(\mathrm{g} * \mathrm{t}), \mathrm{p}(\mathrm{t})\}$ & 5159.27 & 359.53 & 0.00 & 0.00 & 30 & 5098.86 \\
$\{5 \mathrm{Phi}(\mathrm{g} * \mathrm{t}), \mathrm{p}()\}$. & 5330.28 & 530.54 & 0.00 & 0.00 & 30 & 5269.87 \\
\hline
\end{tabular}




\section{Appendix W. Summaries of Covariate Values of Subyearling Chinook Salmon from Data Used in Studies at McNary Dam in 2004-2009.}

Table W1 - Summary statistics of turbine unit discharge (thousand $\mathrm{ft} / \mathrm{s}$ ) during subyearling Chinook salmon passage from data used in studies at McNary Dam in 2004-2009.

[ $N$, number of observations; Min, minimum; Max, maximum; SD, standard deviation; SE, standard error]

\begin{tabular}{lcrccrrrr}
\hline & Year & \multicolumn{1}{c}{$\boldsymbol{N}$} & Min & Max & Mean & Median & SD & SE \\
\hline Overall & 2004 & 500 & 7.80 & 12.50 & 11.07 & 11.70 & 1.33 & 0.06 \\
& 2005 & 117 & 7.92 & 16.60 & 10.95 & 12.00 & 1.96 & 0.18 \\
& 2006 & 435 & 6.20 & 12.95 & 9.94 & 9.61 & 1.30 & 0.06 \\
& 2007 & 276 & 7.85 & 12.24 & 9.78 & 9.48 & 1.24 & 0.07 \\
& 2008 & 308 & 5.05 & 12.43 & 10.57 & 10.65 & 1.58 & 0.09 \\
& 2009 & 273 & 7.87 & 12.35 & 10.02 & 9.87 & 1.26 & 0.08 \\
\hline \multirow{6}{*}{ Day } & Overall & 1909 & 5.05 & 16.60 & 10.39 & 10.32 & 1.48 & 0.03 \\
& 2004 & 245 & 7.80 & 12.50 & 10.63 & 11.10 & 1.50 & 0.10 \\
& 2005 & 41 & 7.92 & 12.30 & 9.75 & 8.74 & 1.77 & 0.28 \\
& 2006 & 114 & 7.96 & 12.53 & 9.15 & 9.10 & 0.76 & 0.07 \\
& 2007 & 94 & 7.88 & 12.24 & 9.54 & 9.20 & 1.29 & 0.13 \\
& 2008 & 79 & 5.05 & 12.43 & 9.97 & 9.57 & 1.72 & 0.19 \\
& 2009 & 113 & 7.87 & 11.86 & 9.44 & 9.24 & 1.12 & 0.11 \\
\hline Night & 2004 & 255 & 7.80 & 12.40 & 11.50 & 11.90 & 0.97 & 0.06 \\
& 2005 & 76 & 8.10 & 16.60 & 11.61 & 12.10 & 1.74 & 0.20 \\
& 2006 & 321 & 6.20 & 12.95 & 10.22 & 9.94 & 1.33 & 0.07 \\
& 2007 & 182 & 7.85 & 12.20 & 9.91 & 9.65 & 1.20 & 0.09 \\
\end{tabular}


Table W2 - Summary statistics of head (feet) during subyearling Chinook salmon passage from data used in studies at McNary Dam in 2004-2009.

[ $N$, number of observations; Min, minimum; Max, maximum; SD, standard deviation; SE, standard error]

\begin{tabular}{ccrcccccc}
\hline & Year & \multicolumn{1}{c}{$\boldsymbol{N}$} & Min & Max & Mean & Median & SD & SE \\
\hline Overall & 2004 & 500 & 71.60 & 76.19 & 74.01 & 73.98 & 1.01 & 0.04 \\
& 2005 & 117 & 70.72 & 76.47 & 72.67 & 72.78 & 1.24 & 0.11 \\
& 2006 & 435 & 69.09 & 75.74 & 72.77 & 72.58 & 1.41 & 0.07 \\
& 2007 & 276 & 71.26 & 75.90 & 73.96 & 73.90 & 0.90 & 0.05 \\
& 2008 & 308 & 69.04 & 75.59 & 72.35 & 71.99 & 1.51 & 0.09 \\
& 2009 & 273 & 70.59 & 76.60 & 74.28 & 74.73 & 1.31 & 0.08 \\
& Overall & 1909 & 69.04 & 76.60 & 73.41 & 73.53 & 1.45 & 0.03 \\
\hline \multirow{6}{*}{ Day } & 2004 & 245 & 71.71 & 76.12 & 74.28 & 74.33 & 0.97 & 0.06 \\
& 2005 & 41 & 71.22 & 76.47 & 73.44 & 73.52 & 1.23 & 0.19 \\
& 2006 & 114 & 69.49 & 75.51 & 73.92 & 74.30 & 1.32 & 0.12 \\
& 2007 & 94 & 71.73 & 75.77 & 74.31 & 74.49 & 0.87 & 0.09 \\
& 2008 & 79 & 69.39 & 75.59 & 72.87 & 72.82 & 1.32 & 0.15 \\
& 2009 & 113 & 70.80 & 76.60 & 74.82 & 75.03 & 0.99 & 0.09 \\
\hline \multirow{6}{*}{ Night } & 2004 & 255 & 71.60 & 76.19 & 73.76 & 73.56 & 0.97 & 0.06 \\
& 2005 & 76 & 70.72 & 74.91 & 72.25 & 71.82 & 1.03 & 0.12 \\
& 2006 & 321 & 69.09 & 75.74 & 72.36 & 72.09 & 1.20 & 0.07 \\
& 2007 & 182 & 71.26 & 75.90 & 73.77 & 73.74 & 0.86 & 0.06 \\
& 2008 & 229 & 69.04 & 75.38 & 72.17 & 71.85 & 1.54 & 0.10 \\
& 2009 & 160 & 70.59 & 76.32 & 73.90 & 74.13 & 1.37 & 0.11 \\
\hline
\end{tabular}


Table W3 - Summary statistics of total project discharge (thousand $\mathrm{ft} 3 / \mathrm{s}$ ) during subyearling Chinook salmon passage from data used in studies at McNary Dam in 2004-2009.

[ $N$, number of observations; Min, minimum; Max, maximum; SD, standard deviation; SE, standard error ]

\begin{tabular}{rrrrrrrrr}
\hline \multirow{5}{*}{ Overall } & Year & \multicolumn{1}{c}{$\boldsymbol{N}$} & \multicolumn{1}{c}{ Min } & \multicolumn{1}{c}{ Max } & \multicolumn{1}{c}{ Mean } & Median & SD & SE \\
& 2004 & 763 & 73.40 & 214.40 & 146.51 & 154.30 & 25.33 & 0.92 \\
& 2005 & 1048 & 150.69 & 225.69 & 190.98 & 192.20 & 18.25 & 0.56 \\
& 2006 & 1191 & 146.33 & 333.97 & 236.52 & 224.55 & 46.50 & 1.35 \\
& 2007 & 1182 & 146.45 & 231.21 & 188.59 & 187.44 & 22.29 & 0.65 \\
& 2008 & 1176 & 132.12 & 355.44 & 238.43 & 221.37 & 74.59 & 2.17 \\
& 2009 & 1187 & 55.41 & 298.39 & 182.54 & 175.53 & 49.08 & 1.42 \\
& Overall & 6547 & 55.41 & 355.44 & 200.64 & 192.58 & 54.58 & 0.67 \\
\hline \multirow{6}{*}{ Day } & 2004 & 173 & 73.40 & 169.70 & 138.88 & 160.10 & 36.83 & 2.80 \\
& 2005 & 314 & 166.99 & 218.90 & 191.38 & 191.00 & 18.59 & 1.05 \\
& 2006 & $\mathrm{NA}$ & $\mathrm{NA}$ & $\mathrm{NA}$ & $\mathrm{NA}$ & $\mathrm{NA}$ & $\mathrm{NA}$ & $\mathrm{NA}$ \\
& 2007 & 30 & 157.86 & 157.86 & 157.86 & 157.86 & 0.00 & 0.00 \\
& 2008 & $\mathrm{NA}$ & $\mathrm{NA}$ & $\mathrm{NA}$ & $\mathrm{NA}$ & $\mathrm{NA}$ & $\mathrm{NA}$ & $\mathrm{NA}$ \\
& 2009 & 299 & 104.24 & 278.15 & 158.50 & 142.12 & 43.35 & 2.51 \\
\hline \multirow{6}{*}{ Night } & 2004 & 590 & 110.40 & 214.40 & 148.74 & 152.20 & 20.29 & 0.84 \\
& 2005 & 734 & 150.69 & 225.69 & 190.81 & 192.55 & 18.11 & 0.67 \\
& 2006 & 1191 & 146.33 & 333.97 & 236.52 & 224.55 & 46.50 & 1.35 \\
& 2007 & 1152 & 146.45 & 231.21 & 189.39 & 187.88 & 22.02 & 0.65 \\
& 2008 & 1176 & 132.12 & 355.44 & 238.43 & 221.37 & 74.59 & 2.17 \\
& 2009 & 888 & 55.41 & 298.39 & 190.64 & 188.25 & 48.26 & 1.62 \\
\hline
\end{tabular}


Table W4 - Summary statistics of spill percentage during subyearling Chinook salmon passage from data used in studies at McNary Dam in 2004-2009.

[ $N$, number of observations; Min, minimum; Max, maximum; SD, standard deviation; SE, standard error]

\begin{tabular}{lcrrrrrrr}
\hline & Year & \multicolumn{1}{c}{$\boldsymbol{N}$} & \multicolumn{1}{c}{ Min } & \multicolumn{1}{c}{ Max } & Mean & Median & \multicolumn{1}{c}{ SD } & \multicolumn{1}{c}{ SE } \\
\hline Overall & 2004 & 1263 & 0.00 & 22.24 & 0.23 & 0.00 & 2.23 & 0.06 \\
& 2005 & 1165 & 0.00 & 77.82 & 56.08 & 70.95 & 27.39 & 0.80 \\
& 2006 & 1626 & 0.72 & 63.71 & 47.71 & 41.64 & 8.81 & 0.22 \\
& 2007 & 1458 & 37.15 & 62.66 & 51.18 & 42.68 & 10.12 & 0.27 \\
& 2008 & 1484 & 0.19 & 62.61 & 51.12 & 51.59 & 8.73 & 0.23 \\
& 2009 & 1460 & 0.00 & 67.85 & 51.18 & 51.25 & 5.22 & 0.14 \\
& Overall & 8456 & 0.00 & 77.82 & 43.57 & 50.79 & 22.14 & 0.24 \\
\hline Day & 2004 & 418 & 0.00 & 0.00 & 0.00 & 0.00 & 0.00 & 0.00 \\
& 2005 & 355 & 10.09 & 77.82 & 59.27 & 70.89 & 24.30 & 1.29 \\
& 2006 & 114 & 39.76 & 63.47 & 46.99 & 41.71 & 8.94 & 0.84 \\
& 2007 & 124 & 37.15 & 62.66 & 46.49 & 41.18 & 9.28 & 0.83 \\
& 2008 & 79 & 37.76 & 62.45 & 50.64 & 44.50 & 9.47 & 1.07 \\
& 2009 & 412 & 49.52 & 67.13 & 51.79 & 51.57 & 1.92 & 0.09 \\
\hline \multirow{6}{*}{ Night } & 2004 & 845 & 0.00 & 22.24 & 0.34 & 0.00 & 2.72 & 0.09 \\
& 2005 & 810 & 0.00 & 77.53 & 54.68 & 71.07 & 28.54 & 1.00 \\
& 2006 & 1512 & 0.72 & 63.71 & 47.77 & 41.64 & 8.80 & 0.23 \\
& 2007 & 1334 & 39.58 & 62.22 & 51.62 & 57.43 & 10.09 & 0.28 \\
& 2008 & 1405 & 0.19 & 62.61 & 51.15 & 51.59 & 8.69 & 0.23 \\
& 2009 & 1048 & 0.00 & 67.85 & 50.94 & 51.17 & 6.03 & 0.19 \\
\hline
\end{tabular}


Table W5 - Summary statistics of tag burden (percent) of subyearling Chinook salmon from data used in studies at McNary Dam in 2004-2009.

[N, number of observations; Min, minimum; Max, maximum; SD, standard deviation; SE, standard error]

\begin{tabular}{lcccccccc}
\hline & Year & $\boldsymbol{N}$ & Min & Max & Mean & Median & SD & SE \\
\hline Overall & 2004 & 1263 & 1.32 & 7.01 & 5.03 & 5.12 & 1.19 & 0.03 \\
& 2005 & 1165 & 1.66 & 5.00 & 3.75 & 3.82 & 0.68 & 0.02 \\
& 2006 & 1626 & 1.78 & 5.93 & 4.75 & 4.88 & 0.76 & 0.02 \\
& 2007 & 1458 & 1.34 & 6.25 & 4.73 & 4.88 & 0.83 & 0.02 \\
& 2008 & 1484 & 0.68 & 6.67 & 4.86 & 4.94 & 0.85 & 0.02 \\
& 2009 & 1460 & 1.38 & 5.93 & 4.18 & 4.32 & 0.91 & 0.02 \\
& Overall & 8456 & 0.68 & 7.01 & 4.57 & 4.65 & 0.97 & 0.01 \\
\hline \multirow{4}{*}{ Nay } & 2004 & 418 & 1.86 & 7.01 & 5.00 & 4.98 & 1.19 & 0.06 \\
& 2005 & 355 & 2.06 & 5.00 & 3.76 & 3.82 & 0.68 & 0.04 \\
& 2006 & 114 & 2.45 & 5.80 & 4.59 & 4.69 & 0.72 & 0.07 \\
& 2007 & 124 & 1.81 & 5.93 & 4.71 & 4.86 & 0.87 & 0.08 \\
& 2008 & 79 & 2.95 & 6.67 & 5.00 & 5.10 & 0.85 & 0.10 \\
& 2009 & 412 & 1.58 & 5.93 & 4.18 & 4.32 & 0.91 & 0.04 \\
\hline 2004 & 845 & 1.32 & 7.01 & 5.05 & 5.18 & 1.19 & 0.04 \\
& 2005 & 810 & 1.66 & 5.00 & 3.75 & 3.82 & 0.69 & 0.02 \\
& 2006 & 1512 & 1.78 & 5.93 & 4.76 & 4.91 & 0.77 & 0.02 \\
& 2007 & 1334 & 1.34 & 6.25 & 4.73 & 4.88 & 0.83 & 0.02 \\
& 2008 & 1405 & 0.68 & 6.67 & 4.85 & 4.94 & 0.84 & 0.02 \\
& 2009 & 1048 & 1.38 & 5.93 & 4.18 & 4.32 & 0.90 & 0.03 \\
\hline
\end{tabular}


Table W6 - Summary statistics of temperature during subyearling Chinook salmon passage from data used in studies at McNary Dam in 2004-2009.

[N, number of observations; Min, minimum; Max, maximum; SD, standard deviation; SE, standard error]

\begin{tabular}{lrrrrrrrr}
\hline & Year & $\boldsymbol{N}$ & Min & Max & Mean & Median & SD & SE \\
\hline Overall & 2004 & 1263 & 18.83 & 21.94 & 20.12 & 20.06 & 0.82 & 0.02 \\
& 2005 & 1165 & 17.11 & 21.06 & 18.76 & 19.06 & 1.08 & 0.03 \\
& 2006 & 1626 & 15.70 & 21.60 & 18.54 & 18.80 & 1.45 & 0.04 \\
& 2007 & 1458 & 16.28 & 20.78 & 18.70 & 19.28 & 1.47 & 0.04 \\
& 2008 & 1484 & 14.56 & 20.06 & 17.84 & 18.28 & 1.55 & 0.04 \\
& 2009 & 1460 & 16.22 & 22.39 & 19.10 & 19.06 & 1.71 & 0.04 \\
Day & Overall & 8456 & 14.56 & 22.39 & 18.81 & 19.17 & 1.55 & 0.02 \\
\hline 2004 & 418 & 18.83 & 21.78 & 20.10 & 19.89 & 0.84 & 0.04 \\
& 2005 & 355 & 17.17 & 21.06 & 18.92 & 19.22 & 1.08 & 0.06 \\
& 2006 & 114 & 16.30 & 21.30 & 19.58 & 19.80 & 1.03 & 0.10 \\
& 2007 & 124 & 16.50 & 20.78 & 19.08 & 19.39 & 1.06 & 0.10 \\
& 2008 & 79 & 15.33 & 20.00 & 18.22 & 18.33 & 1.19 & 0.13 \\
& 2009 & 412 & 16.33 & 22.22 & 19.28 & 19.33 & 1.72 & 0.08 \\
\hline & 2004 & 845 & 18.89 & 21.94 & 20.13 & 20.11 & 0.81 & 0.03 \\
& 2005 & 810 & 17.11 & 20.78 & 18.69 & 18.83 & 1.08 & 0.04 \\
& 2006 & 1512 & 15.70 & 21.60 & 18.47 & 18.70 & 1.45 & 0.04 \\
& 2007 & 1334 & 16.28 & 20.78 & 18.66 & 19.28 & 1.50 & 0.04 \\
& 2008 & 1405 & 14.56 & 20.06 & 17.82 & 18.28 & 1.56 & 0.04 \\
& 2009 & 1048 & 16.22 & 22.39 & 19.03 & 19.00 & 1.70 & 0.05 \\
\hline
\end{tabular}




\section{Appendix X. Capture History Summary of Subyearling Chinook Salmon from Data Used in Studies at McNary Dam in 2004-2009.}

[Occ. represents the occasion number after release. $R(i)$ represents numbers released and $j=2$ and 3 indicate the released number detected at each downstream site]

\begin{tabular}{crrrr}
\hline \multicolumn{5}{c}{ Group 1 control day 2004} \\
Occ. & R(i) & $\mathrm{j}=2$ & $\mathrm{j}=3$ & Total \\
\hline 1 & 590 & 466 & 30 & 496 \\
2 & 466 & & 283 & 283
\end{tabular}

\begin{tabular}{crrrr}
\multicolumn{6}{c}{ Group 7 turbine day 2004} \\
Occ. & R(i) & $\mathrm{j}=2$ & $\mathrm{j}=3$ & Total \\
\hline 1 & 255 & 157 & 14 & 171 \\
2 & 157 & & 95 & 95
\end{tabular}

Group 2 control day 2005

Group 8 turbine day 2005

\begin{tabular}{ccccc} 
Occ. & R(i) & $\mathrm{j}=2$ & $\mathrm{j}=3$ & Total \\
\hline 1 & 734 & 462 & 149 & 611 \\
2 & 462 & & 370 & 370
\end{tabular}

$\begin{array}{ccccc}\text { Occ. } & R(i) & j=2 & j=3 & \text { Total } \\ 1 & 76 & 37 & 16 & 53 \\ 2 & 37 & & 29 & 29\end{array}$

Group 3 control day 2009

Group 9 turbine day 2009

\begin{tabular}{crrrr} 
Occ. & $R(i)$ & $j=2$ & $j=3$ & Total \\
\hline 1 & 888 & 789 & 19 & 808 \\
2 & 789 & & 658 & 658
\end{tabular}

$\begin{array}{crrrr}\text { Occ. } & R(i) & j=2 & j=3 & \text { Total } \\ 1 & 160 & 116 & 1 & 117 \\ 2 & 116 & & 92 & 92\end{array}$

Group 4 control night 2004

Group 10 turbine night 2004

\begin{tabular}{ccccc} 
Occ. & $R(i)$ & $j=2$ & $j=3$ & Total \\
\hline 1 & 173 & 105 & 14 & 119
\end{tabular}

$\begin{array}{llll}2 & 105 & 65 & 65\end{array}$

$\begin{array}{ccccc}\text { Occ. } & R(i) & j=2 & j=3 & \text { Total } \\ 1 & 245 & 125 & 19 & 144 \\ 2 & 125 & & 70 & 70\end{array}$

Group 5 control night 2005

\begin{tabular}{rrrrr} 
Occ. & R(i) & $\mathrm{j}=2$ & $\mathrm{j}=3$ & Total \\
\hline 1 & 314 & 230 & 44 & 274 \\
2 & 230 & & 192 & 192
\end{tabular}

Group 11 turbine night 2005

$\begin{array}{ccccc}\text { Occ. } & \text { R(i) } & \mathrm{j}=2 & \mathrm{j}=3 & \text { Total } \\ 1 & 41 & 19 & 12 & 31 \\ 2 & 19 & & 18 & 18\end{array}$

Group 6 control night 2009

Group 12 turbine night 2009

\begin{tabular}{|c|c|c|c|c|c|c|c|c|c|}
\hline Occ. & $\mathrm{R}(\mathrm{i})$ & $j=2$ & $\mathrm{j}=3$ & Total & Occ. & $\mathrm{R}(\mathrm{i})$ & $j=2$ & $\mathrm{j}=3$ & Total \\
\hline 1 & 299 & 265 & 1 & 266 & 1 & 113 & 69 & 2 & 71 \\
\hline 2 & 265 & & 216 & 216 & 2 & 69 & & 48 & 48 \\
\hline
\end{tabular}




\section{Appendix Y. Results of Correlation Analyses Subyearling Chinook Salmon from Data Used in Studies at McNary Dam in 2004-2005 and 2009.}

Table Y1. Table of correlation indices of data from subyearling Chinook salmon from the turbine group from data used in studies at McNary Dam in 2004, 2005, and 2009.

[ Pearson correlation coefficients are listed above the probabilities of obtaining a greater value under the hypothesis that $\mathrm{Rho}=0$. Sample size is $890 ;<$, less than; see table 2 for variable name definitions]

\begin{tabular}{|c|c|c|c|c|c|c|c|c|c|}
\hline & TOTQ & PER_SPI & HEAD & TURQ & TURLOC & РНОТО & TEMP & WEIGHT & $\begin{array}{c}\text { TAG } \\
\text { BURDEN }\end{array}$ \\
\hline \multirow[t]{2}{*}{ TOTQ } & 1.0000 & 0.4428 & -0.7172 & 0.2668 & 0.0977 & -0.3370 & -0.6506 & -0.2352 & -0.1389 \\
\hline & & $<0.0001$ & $<0.0001$ & $<0.0001$ & 0.0035 & $<0.0001$ & $<0.0001$ & $<0.0001$ & $<0.0001$ \\
\hline \multirow[t]{2}{*}{ PER_SPI } & & 1.0000 & 0.0987 & -0.4328 & 0.1989 & -0.0186 & -0.2085 & -0.1835 & -0.3585 \\
\hline & & & 0.0032 & $<0.0001$ & $<0.0001$ & 0.5794 & $<0.0001$ & $<0.0001$ & $<0.0001$ \\
\hline \multirow[t]{2}{*}{ HEAD } & & & 1.0000 & -0.4883 & 0.0585 & 0.3116 & 0.5662 & 0.1904 & 0.0287 \\
\hline & & & & $<0.0001$ & 0.0811 & $<0.0001$ & $<0.0001$ & $<0.0001$ & 0.3925 \\
\hline \multirow[t]{2}{*}{ TURQ } & & & & 1.0000 & -0.1302 & -0.3232 & -0.2785 & 0.0185 & 0.0931 \\
\hline & & & & & $<0.0001$ & $<0.0001$ & $<0.0001$ & 0.5807 & 0.0054 \\
\hline \multirow[t]{2}{*}{ TURLOC } & & & & & 1.0000 & 0.0343 & 0.0364 & 0.0186 & -0.0295 \\
\hline & & & & & & 0.3066 & 0.2786 & 0.5805 & 0.3793 \\
\hline \multirow[t]{2}{*}{ РНОТО } & & & & & & 1.0000 & 0.1445 & 0.0682 & 0.0238 \\
\hline & & & & & & & $<0.0001$ & 0.0421 & 0.4781 \\
\hline \multirow[t]{2}{*}{ TEMP } & & & & & & & 1.0000 & 0.2297 & 0.1108 \\
\hline & & & & & & & & $<0.0001$ & 0.0009 \\
\hline \multirow[t]{2}{*}{ WEIGHT } & & & & & & & & 1.0000 & -0.6328 \\
\hline & & & & & & & & & $<0.0001$ \\
\hline
\end{tabular}


Table Y2. Table of correlation indices of data from subyearling Chinook salmon from the control group from data used in studies at McNary Dam in 2004-2005 and 2009.

[Pearson correlation coefficients are listed above the probabilities of obtaining a greater value under the hypothesis that $\mathrm{Rho}=0$. Sample size is 2,$998 ;<$, less than; see table 2 for variable name definitions]

\begin{tabular}{|c|c|c|c|c|c|c|}
\hline & TOTQ & PER_SPI & РНОTO & TEMP & WEIGHT & $\begin{array}{c}\text { TAG } \\
\text { BURDEN }\end{array}$ \\
\hline \multirow[t]{2}{*}{ TOTQ } & 1.0000 & 0.3941 & -0.1364 & -0.6318 & -0.2725 & -0.0937 \\
\hline & & $<0.0001$ & $<0.0001$ & $<0.0001$ & $<0.0001$ & $<0.0001$ \\
\hline \multirow[t]{2}{*}{ PER_SPI } & & 1.0000 & 0.0631 & -0.1137 & -0.2930 & -0.4022 \\
\hline & & & 0.0005 & $<0.0001$ & $<0.0001$ & $<0.0001$ \\
\hline \multirow[t]{2}{*}{ РНОТО } & & & 1.0000 & 0.0036 & -0.0380 & -0.0373 \\
\hline & & & & 0.8421 & 0.0374 & 0.0412 \\
\hline \multirow[t]{2}{*}{ TEMP } & & & & 1.0000 & 0.2450 & 0.0250 \\
\hline & & & & & $<0.0001$ & 0.1720 \\
\hline \multirow[t]{2}{*}{ WEIGHT } & & & & & 1.0000 & -0.4751 \\
\hline & & & & & & $<0.0001$ \\
\hline
\end{tabular}




\section{Appendix Z. Model Summary from Analyses of Recapture Probabilities ( $p$ ) of Subyearling Chinook Salmon from Data used in Studies at McNary Dam in 2004-2005 and 2009.}

[Models of $\mathrm{p}$ include those in which values can vary in various combinations of detection site ( $\mathrm{t}$ ) and group (treatment, year, and photoperiod). $\mathrm{A}^{\prime} *^{\prime}$ indicated a multiplicative effect, a ' + ' indicates an additive effect, and a '.' indicates a common value fitted to all groups and reaches. A multiplicative model ( $\left.\mathrm{g}^{*} \mathrm{t}\right)$ of apparent survival (phi) was used in all models. $\mathrm{K}$ indicates the number of estimable parameters]

\begin{tabular}{lcccccr}
\multicolumn{1}{c}{ Model } & AlCc & $\begin{array}{c}\text { Delta } \\
\text { AICc }\end{array}$ & $\begin{array}{c}\text { AlCc } \\
\text { Weights }\end{array}$ & $\begin{array}{c}\text { Model } \\
\text { Likelihood }\end{array}$ & K & Deviance \\
\hline$\left\{1\right.$ Phi $\left.\left(\mathrm{g}^{*} \mathrm{t}\right), \mathrm{p}(\mathrm{g} * \mathrm{t})\right\}$ & 8445.31 & 0.00 & 1.00 & 1.00 & 36 & 8307.72 \\
$\{2 \mathrm{Phi}(\mathrm{g} * \mathrm{t}), \mathrm{p}(\mathrm{g}+\mathrm{t})\}$ & 8645.42 & 200.10 & 0.00 & 0.00 & 36 & 8573.02 \\
$\{3$ Phi $(\mathrm{g} * \mathrm{t}), \mathrm{p}(\mathrm{g})\}$ & 8792.06 & 346.75 & 0.00 & 0.00 & 36 & 8719.66 \\
$\{4 \operatorname{Phi}(\mathrm{g} * \mathrm{t}), \mathrm{p}(\mathrm{t})\}$ & 8817.73 & 372.41 & 0.00 & 0.00 & 25 & 8767.53 \\
$\{5$ Phi $(\mathrm{g} * \mathrm{t}), \mathrm{p}()\}$. & 8964.37 & 519.05 & 0.00 & 0.00 & 25 & 8914.17 \\
\hline
\end{tabular}




\section{Appendix AA. Model-selection Results from Radio- and Acoustic-tagged Subyearling Chinook Salmon from Data used in Studies at McNary Dam in 2004-2005 and 2009.}

[Presence of a factor in a model is indicated by an ' $x$ ' in the column for that factor. Model 1 was a global model including all group covariates and their interactions (g) as well as all individual covariates and interactions listed. Distance to the first downriver gate (gated) was only used when year was present in the model. All models shared a common $\mathrm{g}$ *reach model of recapture probability. K indicates the number of parameters. Unlike other analyses in this report, a treatment and weight interaction (trt*wt) was tested post hoc here instead of the weight main effect because the treatment and tag burden interaction (trt*tagb) was supported rather than the tag burden main effect in this data set]

\begin{tabular}{|c|c|c|c|c|c|c|c|c|c|c|c|c|c|c|c|c|c|c|c|c|c|c|c|c|c|c|c|c|}
\hline \multirow[b]{3}{*}{$\begin{array}{c}\text { Model } \\
\text { Numbe } \\
r\end{array}$} & \multirow{2}{*}{\multicolumn{8}{|c|}{ Group Covariates }} & \multicolumn{17}{|c|}{ Individual Covariates } & \multirow{2}{*}{\multicolumn{3}{|c|}{$\begin{array}{c}\text { Model Selection } \\
\text { Results } \\
\end{array}$}} \\
\hline & & & & & & & & & \multicolumn{8}{|c|}{ Biological } & \multicolumn{9}{|c|}{ Operational } & & & \\
\hline & ס & 튼 & 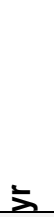 & $\begin{array}{l}\text { 융 } \\
\text { 등 }\end{array}$ & 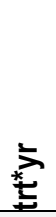 & $\begin{array}{l}\text { 옿 } \\
\frac{1}{2} \\
\frac{*}{ \pm} \\
\end{array}$ & $\begin{array}{l}\text { 은 } \\
\text { 응 } \\
\text { * }\end{array}$ & 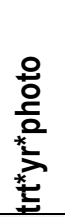 & 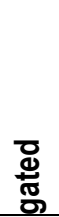 & 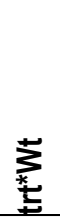 & 음 & $\begin{array}{l}\text { 음 } \\
\text { 妾 } \\
\text { ț }\end{array}$ & 年 & ᄅํㄹㄹ & 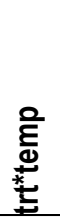 & 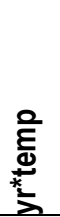 & 음 & $\begin{array}{l}\frac{0}{0} \\
\frac{2}{2} \\
\frac{*}{5}\end{array}$ & 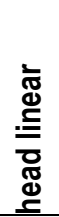 & 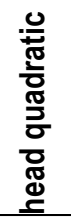 & 은 & 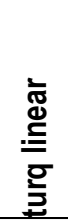 & 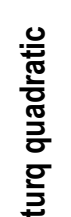 & $\begin{array}{l}\text { 응 } \\
\text { 응 } \\
\text { 언 } \\
\text { 은 }\end{array}$ & 몽 & AlCc & K & $\begin{array}{c}\text { Devianc } \\
\mathrm{e}\end{array}$ \\
\hline 1 & $\mathrm{x}$ & $\mathrm{x}$ & $\mathrm{x}$ & $\mathrm{x}$ & $\mathrm{x}$ & $\mathrm{x}$ & $\mathrm{x}$ & $\mathrm{x}$ & & & $\mathrm{x}$ & $\mathrm{x}$ & $\mathrm{x}$ & $\mathrm{x}$ & $\mathrm{x}$ & $\mathrm{x}$ & $\mathrm{x}$ & $\mathrm{x}$ & $\mathrm{x}$ & & $\mathrm{x}$ & $\mathrm{x}$ & & $\mathrm{x}$ & $\mathrm{x}$ & 8986. & 4 & 8888.0 \\
\hline 2 & $\mathrm{x}$ & $\mathrm{x}$ & $\mathrm{x}$ & $\mathrm{x}$ & $\mathrm{x}$ & $\mathrm{x}$ & $\mathrm{x}$ & $\mathrm{x}$ & & & $\mathrm{x}$ & $\mathrm{x}$ & & $x$ & $\mathrm{x}$ & $\mathrm{x}$ & $x$ & $\mathrm{x}$ & $\mathrm{x}$ & & $\mathrm{x}$ & $\mathrm{x}$ & & $\mathrm{x}$ & $\mathrm{x}$ & 8283 & 4 & 8188.6 \\
\hline 3 & $\mathrm{x}$ & $\mathrm{X}$ & $\mathrm{x}$ & $\mathrm{x}$ & $\mathrm{x}$ & $\mathrm{x}$ & $\mathrm{x}$ & $\mathrm{x}$ & & & $\mathrm{X}$ & $\mathrm{x}$ & & $\mathrm{x}$ & $\mathrm{x}$ & & $\mathrm{x}$ & $\mathrm{x}$ & $\mathrm{x}$ & & $\mathrm{x}$ & $\mathrm{x}$ & & $\mathrm{X}$ & $\mathrm{X}$ & 8303. & 4 & 8212.4 \\
\hline $4 a$ & & $\mathrm{x}$ & & $\mathrm{x}$ & & $\mathrm{x}$ & & & $\mathrm{x}$ & & $\mathrm{x}$ & $\mathrm{x}$ & & $\mathrm{x}$ & $\mathrm{x}$ & $x$ & $\mathrm{x}$ & $\mathrm{x}$ & $\mathrm{x}$ & & $\mathrm{x}$ & $\mathrm{x}$ & & $\mathrm{x}$ & $\mathrm{x}$ & 8306. & 3 & 8227.5 \\
\hline $4 b$ & & $\mathrm{x}$ & $\mathrm{x}$ & $\mathrm{x}$ & $\mathrm{x}$ & $\mathrm{x}$ & $\mathrm{x}$ & & & & $\mathrm{x}$ & $\mathrm{x}$ & & $\mathrm{x}$ & $\mathrm{x}$ & $\mathrm{x}$ & $\mathrm{x}$ & $\mathrm{x}$ & $\mathrm{x}$ & & $x$ & $\mathrm{x}$ & & $\mathrm{x}$ & $\mathrm{x}$ & 8282. & 4 & 8191.8 \\
\hline $4 c$ & & $\mathrm{x}$ & $\mathrm{x}$ & $\mathrm{x}$ & & $\mathrm{x}$ & $\mathrm{x}$ & & & & $\mathrm{x}$ & $\mathrm{x}$ & & $\mathrm{X}$ & $x$ & $\mathrm{x}$ & $\mathrm{x}$ & $x$ & $x$ & & $\mathrm{x}$ & $\mathrm{x}$ & & $\mathrm{X}$ & $\mathrm{x}$ & 8279 . & 4 & 8193.0 \\
\hline $4 d$ & & $\mathrm{x}$ & $\mathrm{x}$ & $\mathrm{x}$ & & $\mathrm{x}$ & & & & & $\mathrm{x}$ & $\mathrm{x}$ & & $\hat{x}$ & $\hat{\mathrm{X}}$ & $\hat{x}$ & $\hat{x}$ & $\hat{x}$ & $\hat{x}$ & & $\hat{x}$ & $\hat{x}$ & & $\hat{x}$ & $\hat{x}$ & 8281 . & 4 & 8198.8 \\
\hline 5 & & $\mathrm{x}$ & $x$ & $\mathrm{x}$ & & & $\mathrm{x}$ & & & & $\mathrm{x}$ & $\mathrm{x}$ & & $\mathrm{x}$ & $\mathrm{x}$ & $\mathrm{x}$ & $\mathrm{x}$ & $\mathrm{x}$ & $\mathrm{x}$ & & $x$ & $\mathrm{x}$ & & $\mathrm{x}$ & $\mathrm{x}$ & 8277 & 4 & 8193.1 \\
\hline 6 & & $\mathrm{x}$ & $x$ & & & & $\mathrm{x}$ & & & & $\mathrm{x}$ & $\mathrm{x}$ & & $\mathrm{x}$ & $\mathrm{x}$ & $\mathrm{x}$ & $\mathrm{x}$ & $\mathrm{x}$ & $\mathrm{x}$ & & $\mathrm{x}$ & $\mathrm{x}$ & & $\mathrm{x}$ & $\mathrm{x}$ & 8285 . & 4 & 8203.0 \\
\hline 7 & & $\mathrm{X}$ & $\mathrm{X}$ & $\mathrm{x}$ & & & $\mathrm{x}$ & & & & $\mathrm{X}$ & $\mathrm{x}$ & & $\mathrm{X}$ & & $\mathrm{X}$ & $\mathrm{x}$ & $\mathrm{X}$ & $\mathrm{x}$ & & $\mathrm{x}$ & $\mathrm{x}$ & & $\mathrm{X}$ & $\mathrm{x}$ & 8276 . & 4 & 8193.7 \\
\hline 8 & & $\mathrm{x}$ & $\mathrm{x}$ & $\mathrm{x}$ & & & $\mathrm{x}$ & & & & $\mathrm{x}$ & $\mathrm{x}$ & & $\mathrm{x}$ & & $\mathrm{x}$ & $\mathrm{x}$ & $\mathrm{x}$ & $\mathrm{x}$ & & $\mathrm{x}$ & $\mathrm{x}$ & & & $\mathrm{x}$ & 8277. & 4 & 8196.7 \\
\hline 9 & & $\mathrm{x}$ & $\mathrm{x}$ & $\mathrm{x}$ & & & $\mathrm{x}$ & & & & $\mathrm{x}$ & $\mathrm{x}$ & & $\mathrm{x}$ & & $\mathrm{x}$ & $\mathrm{x}$ & & $\mathrm{x}$ & & $\mathrm{x}$ & $\mathrm{x}$ & & $\mathrm{x}$ & $\mathrm{x}$ & 8277. & 4 & 8197.0 \\
\hline 10 & & $\mathrm{x}$ & $\mathrm{x}$ & $\mathrm{x}$ & & & $\mathrm{x}$ & & & & $\mathrm{x}$ & $\mathrm{x}$ & & & & $\mathrm{x}$ & $\mathrm{x}$ & $\mathrm{x}$ & $\mathrm{x}$ & & $x$ & $\mathrm{x}$ & & $\mathrm{x}$ & $\mathrm{x}$ & 8278 . & 4 & 8197.6 \\
\hline 11 & & $\mathrm{x}$ & $\mathrm{x}$ & $\mathrm{x}$ & & & $\mathrm{x}$ & & & & $\mathrm{x}$ & $\mathrm{x}$ & & $\mathrm{x}$ & & $\mathrm{x}$ & $\mathrm{x}$ & $\mathrm{x}$ & $\mathrm{x}$ & & $\mathrm{x}$ & $\mathrm{x}$ & & $\mathrm{x}$ & & 8274 . & 4 & 8194.0 \\
\hline 12 & & $\mathrm{X}$ & $\mathrm{X}$ & $x$ & & & $\mathrm{X}$ & & & & $\mathrm{X}$ & $\mathrm{x}$ & & $\mathrm{X}$ & & $\mathrm{x}$ & & $\mathrm{x}$ & $\mathrm{x}$ & & $\mathrm{x}$ & $\mathrm{x}$ & & $\mathrm{X}$ & & 8272 . & 3 & 8194.0 \\
\hline 13 & & $\mathrm{x}$ & $\mathrm{x}$ & $\mathrm{x}$ & & & $\mathrm{x}$ & & & & $\mathrm{x}$ & $\mathrm{x}$ & & $\mathrm{x}$ & & $\mathrm{x}$ & & $\mathrm{x}$ & $\mathrm{x}$ & & & $\mathrm{x}$ & & $\mathrm{x}$ & & 8273 & 3 & 8196.9 \\
\hline $14 a$ & & $\mathrm{x}$ & $\mathrm{x}$ & $\mathrm{x}$ & & & $\mathrm{x}$ & & & & $\mathrm{x}$ & $\mathrm{x}$ & & $\mathrm{x}$ & & $\mathrm{x}$ & & $\mathrm{x}$ & & & $\mathrm{x}$ & $\mathrm{x}$ & & $\mathrm{x}$ & & 8268 . & 3 & 8194.0 \\
\hline $14 b$ & & $\mathrm{x}$ & $\mathrm{x}$ & $\mathrm{x}$ & & & $\mathrm{x}$ & & & & $\mathrm{x}$ & $\mathrm{x}$ & & $\mathrm{x}$ & & $\mathrm{x}$ & & $\mathrm{x}$ & & $\mathrm{x}$ & $\mathrm{x}$ & $\mathrm{x}$ & & $\mathrm{x}$ & & 8274 . & 3 & 8196.1 \\
\hline $15 a$ & & $\mathrm{x}$ & $\mathrm{x}$ & $\mathrm{x}$ & & & $\mathrm{x}$ & & & & $\mathrm{x}$ & $\mathrm{x}$ & & $\mathrm{x}$ & & $x$ & & $\mathrm{x}$ & & & $\mathrm{x}$ & & & $\mathrm{x}$ & & 8266. & 3 & 8194.1 \\
\hline $15 b$ & & $\hat{x}$ & $\hat{x}$ & $\hat{x}$ & & & $\hat{x}$ & & & & $\hat{x}$ & $\hat{x}$ & & $\hat{x}$ & & $\hat{x}$ & & $\hat{x}$ & & & $\hat{x}$ & & $\mathrm{x}$ & $\hat{x}$ & & 8269 . & 3 & 8193.3 \\
\hline 16 & & $\hat{x}$ & $\hat{x}$ & $\hat{x}$ & & & $\hat{x}$ & & & & $\hat{x}$ & & & $\hat{x}$ & & $\hat{x}$ & & $\hat{x}$ & & & $\hat{x}$ & & & $\hat{x}$ & & 8267. & 3 & 8197.5 \\
\hline $17 *$ & & $\mathrm{x}$ & $\mathrm{X}$ & $\mathrm{x}$ & & & $\mathrm{x}$ & & & & & $\mathrm{x}$ & & $\mathrm{x}$ & & $\mathrm{x}$ & & $\mathrm{x}$ & & & $\mathrm{x}$ & & & $\mathrm{x}$ & & 8264 . & 3 & 8194.1 \\
\hline 18 & & $\mathrm{x}$ & $x$ & $\mathrm{x}$ & & & $\mathrm{x}$ & & & $\mathrm{x}$ & & & & $\mathrm{x}$ & & $\mathrm{x}$ & & $\mathrm{x}$ & & & $\mathrm{x}$ & & & $\mathrm{X}$ & & 8267 . & 3 & 8196.7 \\
\hline
\end{tabular}




\section{Appendix AB. Beta (Slope) Coefficients of Estimable Survival Parameters of Subyearling Chinook Salmon from Data used in Studies at McNary Dam in 2004-2005 and 2009.}

[The data are from model 17 in appendix AA]

\begin{tabular}{|c|c|c|c|c|}
\hline \multirow[b]{2}{*}{ Parameter } & \multirow[b]{2}{*}{ Beta } & \multirow{2}{*}{$\begin{array}{l}\text { Standard } \\
\text { Error }\end{array}$} & \multicolumn{2}{|c|}{ 95\% Confidence } \\
\hline & & & Lower & Upper \\
\hline Intercept & 6.064139 & 1.900079 & 2.339984 & 9.788295 \\
\hline treatment & 0.376022 & 0.462350 & -0.530190 & 1.282228 \\
\hline photo & -0.738320 & 0.206600 & -1.143260 & -0.333390 \\
\hline 2005 & -6.999290 & 2.680197 & -12.252500 & -1.746100 \\
\hline 2009 & 6.903824 & 2.236789 & 2.519718 & 11.287930 \\
\hline photo*2005 & 0.847542 & 0.316948 & 0.226325 & 1.468760 \\
\hline photo $* 2009$ & 0.351506 & 0.253333 & -0.145030 & 0.848038 \\
\hline tag burden*treatment & -0.201000 & 0.079477 & -0.356770 & -0.045220 \\
\hline spill percentage $*$ treatment & -0.010710 & 0.004455 & -0.019440 & -0.001980 \\
\hline turbine location & -0.044660 & 0.026510 & -0.096620 & 0.007298 \\
\hline turbine location*photo & 0.045399 & 0.025110 & -0.003820 & 0.094615 \\
\hline temp & -0.206850 & 0.093677 & -0.390460 & -0.023240 \\
\hline temp*2005 & 0.367133 & 0.139097 & 0.094503 & 0.639763 \\
\hline temp*2009 & -0.333630 & 0.110448 & -0.550100 & -0.117150 \\
\hline
\end{tabular}




\section{Appendix AC. Capture History Summary of Subyearling Chinook Salmon from Data Used in Studies at McNary Dam in 2004-2009.}

[Occ. represents the Occasion number after release. $R(i)$ represents numbers released and $\mathrm{j}=2$ and 3 indicate the released number detected at each downstream site]

\begin{tabular}{|c|c|c|c|c|c|c|c|c|c|c|c|c|c|c|}
\hline \multicolumn{5}{|c|}{ Group 1 control day 2004} & \multicolumn{5}{|c|}{ Group 9 control night 2007} & \multicolumn{5}{|c|}{ Group 17 turbine night 2004} \\
\hline Occ & $\mathrm{R}(\mathrm{i})$ & $\mathrm{j}=2$ & $\mathrm{j}=3$ & Total & Occ. & $\mathrm{R}(\mathrm{i})$ & $j=2$ & $\mathrm{j}=3$ & Total & Occ. & $\mathrm{R}(\mathrm{i})$ & $j=2$ & $\mathrm{j}=3$ & Total \\
\hline 1 & 590 & 466 & 30 & 496 & 1 & 30 & & 16 & 25 & 1 & 245 & 125 & & 14 \\
\hline 2 & 466 & & 283 & 283 & 2 & $\mathrm{~g}$ & & 8 & 8 & 2 & 125 & & & 70 \\
\hline
\end{tabular}

Group 2 control day 2005

\begin{tabular}{|c|c|c|c|c|}
\hline Occ. & $\mathrm{R}(\mathrm{i})$ & $\mathrm{j}=2$ & $j=3$ & Total \\
\hline 1 & & 462 & 149 & 61 \\
\hline & 462 & & 370 & 37 \\
\hline
\end{tabular}

Group 3 control day 2006

\begin{tabular}{rrrrr} 
Occ. & R(i) & $\mathrm{j}=2$ & $\mathrm{j}=3$ & \multicolumn{1}{c}{ Total } \\
\hline 114 & 1191 & 936 & 150 & 1086 \\
74 & 936 & & 801 & 801
\end{tabular}

Group 4 control day 2007

\begin{tabular}{|c|c|c|c|c|}
\hline Occ. & $\mathrm{R}(\mathrm{i})$ & $\mathrm{j}=2$ & $\mathrm{j}=3$ & Total \\
\hline 1 & 1152 & 382 & 567 & 949 \\
\hline 2 & 382 & & 317 & 317 \\
\hline
\end{tabular}

Group 5 control day 2008

\begin{tabular}{crrrr} 
Occ. & R(i) & $\mathrm{j}=2$ & $\mathrm{j}=3$ & Total \\
\hline 1 & 1176 & 961 & 95 & 1056 \\
2 & 961 & & 851 & 851
\end{tabular}

Group 6 control day 2009

$\begin{array}{crrrr}\text { Occ. } & R(i) & j=2 & j=3 & \text { Total } \\ 1 & 888 & 789 & 19 & 808 \\ 2 & 789 & & 658 & 658\end{array}$

Group 7 control night 2004

\begin{tabular}{crrrr} 
Occ. & $R(i)$ & $j=2$ & $j=3$ & Total \\
\hline 1 & 173 & 105 & 14 & 119 \\
2 & 105 & & 65 & 65
\end{tabular}

Group 8 control night 2005

\begin{tabular}{crrrr} 
Occ. & $R(\mathrm{i})$ & $\mathrm{j}=2$ & $\mathrm{j}=3$ & Total \\
\hline 1 & 314 & 230 & 44 & 274 \\
2 & 230 & & 192 & 192 \\
\hline
\end{tabular}

Group 10 control night 2009

\begin{tabular}{cccrr} 
Occ. & $R(i)$ & $j=2$ & $j=3$ & Total \\
\hline 1 & 299 & 265 & 1 & 266 \\
2 & 265 & & 216 & 216
\end{tabular}

Group 11 turbine day 2004

\begin{tabular}{crrrr} 
Occ. & $R(i)$ & $j=2$ & $j=3$ & Total \\
\hline 1 & 255 & 157 & 14 & 171 \\
2 & 157 & & 95 & 95
\end{tabular}

Group 12 turbine day 2005

\begin{tabular}{ccccc} 
Occ. & $R(i)$ & $j=2$ & $j=3$ & Total \\
\hline 1 & 76 & 37 & 16 & 53 \\
2 & 37 & & 29 & 29
\end{tabular}

Group 13 turbine day 2006

\begin{tabular}{ccrrr} 
Occ. & R(i) & $j=2$ & $j=3$ & Total \\
\hline 1 & 321 & 202 & 32 & 234 \\
2 & 202 & & 172 & 172
\end{tabular}

Group 14 turbine day 2007

\begin{tabular}{crrrr} 
Occ. & $R(i)$ & $j=2$ & $j=3$ & Total \\
\hline 1 & 182 & 64 & 64 & 128 \\
2 & 64 & & 50 & 50
\end{tabular}

Group 15 turbine day 2008

\begin{tabular}{crrrr} 
Occ. & $R(\mathrm{i})$ & $\mathrm{j}=2$ & $\mathrm{j}=3$ & Total \\
\hline 1 & 232 & 156 & 13 & 169 \\
2 & 156 & & 137 & 137
\end{tabular}

Group 18 turbine night 2005

Occ. $R(i) \quad j=2 \quad j=3 \quad$ Total

$\begin{array}{llll}2 & 19 & 18 & 18\end{array}$

Group 19 turbine night 2006

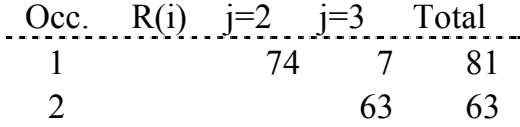

Group 20 turbine night 2007

$\begin{array}{ccccc}\text { Occ. } & R(i) & j=2 & j=3 & \text { Total } \\ 1 & 94 & 31 & 19 & 50 \\ 2 & 31 & & 29 & 29\end{array}$

Group 21 turbine night 2008

$\begin{array}{ccccc}\text { Occ. } & R(i) & j=2 & j=3 & \text { Total } \\ 1 & 79 & 61 & 5 & 66 \\ 2 & 61 & & 50 & 50\end{array}$

Group 22 turbine night 2009

\begin{tabular}{ccccc} 
Occ. & R(i) & $\mathrm{j}=2$ & $\mathrm{j}=3$ & Total \\
\hline 1 & 113 & 69 & 2 & 71 \\
2 & 69 & & 48 & 48
\end{tabular}
Group 16 turbine day 2009

\begin{tabular}{crrrr} 
Occ. & R(i) & $\mathrm{j}=2$ & $\mathrm{j}=3$ & Total \\
\hline 1 & 160 & 116 & 1 & 117 \\
2 & 116 & & 92 & 92
\end{tabular}




\section{Appendix AD. Model Summary from Analyses of Recapture Probabilities ( $p$ ) of Subyearling Chinook Salmon from Data used in Studies at McNary Dam in 2004-2009.}

[Models of $p$ include those in which values can vary in various combinations of detection site ( $t$ ) and group (treatment, year, and photoperiod). $\mathrm{A}^{\prime} *^{\prime}$ indicated a multiplicative effect, a ' + ' indicates an additive effect, and a '.' indicates a common value fitted to all groups and reaches. A multiplicative model ( $\mathrm{g} * \mathrm{t})$ of apparent survival (phi) was used in all models. $\mathrm{K}$ indicates the number of estimable parameters]

\begin{tabular}{lrrcccc}
\hline \multicolumn{1}{c}{ Model } & \multicolumn{1}{c}{ AlCc } & Delta AICc & AlCc Weights & Model Likelihood & K & Deviance \\
\hline$\left\{1\right.$ Phi $\left.\left(\mathrm{g}^{*} \mathrm{t}\right), \mathrm{p}(\mathrm{g} * \mathrm{t})\right\}$ & 17951.17 & 0.00 & 1.00 & 1.00 & 66 & 17818.54 \\
$\{2 \mathrm{Phi}(\mathrm{g} * \mathrm{t}), \mathrm{p}(\mathrm{g})\}$ & 18907.49 & 956.33 & 0.00 & 0.00 & 66 & 18774.86 \\
$\{3$ Phi $(\mathrm{g} * \mathrm{t}), \mathrm{p}(\mathrm{g}+\mathrm{t})\}$ & 18921.35 & 970.19 & 0.00 & 0.00 & 66 & 18788.73 \\
$\{4$ Phi $(\mathrm{g} * \mathrm{t}), \mathrm{p}(\mathrm{t})\}$ & 19677.74 & 1726.57 & 0.00 & 0.00 & 45 & 19587.44 \\
$\{5$ Phi $(\mathrm{g} * \mathrm{t}), \mathrm{p}()\}$. & 19692.38 & 1741.21 & 0.00 & 0.00 & 45 & 19602.08 \\
\hline
\end{tabular}


This page left intentionally blank 
Publishing support provided by the U.S. Geological Survey

Publishing Network, Tacoma Publishing Service Center

For more information concerning the research in this report, contact the Director, Western Fisheries Research Center U.S. Geological Survey

6505 NE 65th Street

Seattle, Washington 98115

http://wfrc.usgs.gov/ 


\section{昜}

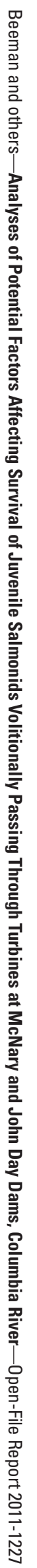

